\author{
UNIVERSIDADE DE SÃO PAULO \\ FACULDADE DE FILOSOFIA, LETRAS E CIÊNCIAS HUMANAS \\ DEPARTAMENTO DE LETRAS ORIENTAIS \\ PROGRAMA DE PÓS-GRADUAÇÃO EM LÍNGUA HEBRAICA, \\ LITERATURA E CULTURA JUDAICAS
}

\title{
A TEOLOGIA JUDAICA DO HOLOCAUSTO \\ Como os pensadores ortodoxos modernos enfrentaram o desafio de explicar a Shoá
}

\begin{abstract}
Ariel Finguerman
Tese apresentada ao Programa de Pós-Graduação em Língua Hebraica, Literatura e Cultura Judaicas do Departamento de Letras Orientais da Faculdade de Filosofia, Letras e Ciências Humanas da Universidade de São Paulo, para obtenção do título de Doutor em Letras.
\end{abstract}

Orientadora: Profa. Dra. Jaffa Rifka Berezin

São Paulo 


\begin{abstract}
UNIVERSIDADE DE SÃO PAULO
FACULDADE DE FILOSOFIA, LETRAS E CIÊNCIAS HUMANAS DEPARTAMENTO DE LETRAS ORIENTAIS PROGRAMA DE PÓS-GRADUAÇÃO EM LÍNGUA HEBRAICA, LITERATURA E CULTURA JUDAICAS
\end{abstract}

\title{
A TEOLOGIA JUDAICA DO HOLOCAUSTO \\ Como os pensadores ortodoxos modernos enfrentaram o desafio de explicar a Shoá
}

Ariel Finguerman

São Paulo 


\section{AGRADECIMENTOS}

À Profa. Jaffa Rifka Berezin, fonte de sabedoria e experiência, que alimentou com generosidade este trabalho.

À população do Estado de São Paulo, que através da Fapesp, concedeu um generoso apoio à esta pesquisa.

Ao Prof. Shalom Ratzabi, da Universidade de Tel Aviv, co-orientador desta tese durante os meses de pesquisa em Israel.

Ao seguintes especialistas, com quem encontrei-me durante o decorrer desta pesquisa e que me deram valiosas contribuições: Prof. Menachem Fisch, da Universidade de Tel Aviv, especialista em Pensamento Rabinico; Prof. Gershon Greenberg, da American University, especialista em Teologia do Holocausto; David Hazony, editor da obra de Eliezer Berkovits em Israel; Prof. Ron Margolin, da Universidade de Tel Aviv, especialista em Teologia do Holocausto; Prof. Eli Turkel, da Universidade de Tel Aviv, especialista na obra de Joseph Soloveitchik.

Um agradecimento especial ao Prof. Jacob Dolinger, da Universidade do Estado do Rio de Janeiro, erudito em Judaísmo, que leu todo o manuscrito e fez valiosas considerações.

Aos seguintes especialistas, que trocaram correspondência comigo contribuindo para esta tese: Prof David Shatz e Prof. Shalom Carmy, ambos da Yeshiva University de Nova Iorque e especialistas na obra de Soloveitchik; Prof Aviezer Ravitzky, da Universidade Hebraica de Jerusalém, especialista em Pensamento Judaico; Reuven Ziegler, editor da obra de Soloveitchik.

A David Shahor, do Kolel Ohel Yaakov de Bnei Brak, pela amizade e prontidão em esclarecer grandes questões e pequenos detalhes sobre o judaísmo. 


\section{RESUMO}

Esta tese de doutorado aborda a chamada Teologia Judaica do Holocausto, ou seja, as reflexões realizadas por rabinos e pensadores judeus a respeito da perseguição nazista e suas consequências no plano da religião. A tese concentra-se no estudo de uma corrente judaica especíifica, a Ortodoxia Moderna dos EUA, representada aqui por seus mais importantes pensadores da Shoá - Joseph Soloveitchik, Eliezer Berkovits e Irving Greenberg. A pesquisa expõe estas reflexões, insere-as no contexto mais geral do pensamento judaico e analisa suas contribuições ao judaísmo pósHolocausto.

\section{ABSTRACT}

This doctoral thesis researches the so-called Jewish Holocaust Theology, i.e. reflections of rabbis and Jewish thinkers concerning Nazi persecution and its implications on the religious level. The thesis concentrates on one specific Jewish religious stream: North-American Modern Orthodoxy, represented here by its most important thinkers on the Shoah - Joseph Soloveitchik, Eliezer Berkovits and Irving Greenberg. The research reveals their reflections, inserts them into the more general context of Jewish thought and analyzes their contribution to post-Holocaust Judaism.

\section{PALAVRAS-CHAVE/KEY WORDS}

Holocausto / Shoá / Teologia / Judaísmo / Ortodoxia Moderna

Holocaust / Shoah / Theology / Judaism / Modern Orthodoxy 


\section{TRANSLITERACÕES, PADRONIZACÕES E ABREVIATURAS}

As transliterações de termos hebraicos para o português nesta tese seguem, de forma geral, o padrão proposto pela Encyclopaedia Judaica, Second Edition, $2007^{1}$.

O uso de colchetes [] e parênteses () em citações e traduções seguiu o seguinte padrão: informações entre colchetes são adições ao texto original necessárias a melhor compreensão do sentido original; informações entre parênteses são explicações do autor desta tese destinadas à clarificação da citação.

Abreviaturas convencionadas:

Bíblia Hebraica $=\mathrm{BH}$

Novo Testamento $=$ NT

Talmud da Babilônia $=\mathrm{TB}$

Abreviaturas de livros bíblicos:

$\begin{array}{ll}\mathrm{Ab} & \text { Abdias } \\ \mathrm{Ag} & \text { Ageu } \\ \mathrm{Am} & \text { Amós } \\ 1 \mathrm{Cr} & \text { 1o Livro de Crônicas } \\ 1 \mathrm{Cr} & \text { 1o Livro de Crônicas } \\ \mathrm{Ct} & \text { Cântico dos Cânticos } \\ \mathrm{Dn} & \text { Daniel } \\ \mathrm{Dt} & \text { Deuteronômio } \\ \mathrm{Ecl} & \text { Eclesiastes } \\ \mathrm{Esd} & \text { Esdras } \\ \mathrm{Est} & \text { Ester } \\ \mathrm{Ex} & \text { Exxodo } \\ \mathrm{Ez} & \text { Ezequiel } \\ \mathrm{Gn} & \text { Gênesis } \\ \mathrm{Hab} & \text { Habacuc } \\ \mathrm{Is} & \text { Isaías } \\ \mathrm{Jo} & \text { Jó } \\ \mathrm{Jl} & \text { Joel }\end{array}$

${ }^{1}$ Vol 1, pg. 197.

Esta tese não seguiu o padrão da Encyclopaedia Judaica em transliterações que se afastam muito do uso mais comum em português. Por exemplo, optamos por não duplicar consoantes (ao invés de aggadah, utilizamos agadah). Porém, alguns nomes já consagrados, como piyyut, seguem o padrão da Encyclopaedia Judaica.

Optamos também por certas palavras já consagradas em português, como Torá (ao invés de Torah). Por uma questão de simplificação, optamos por não utilizar pontos inferiores, como por exemplo, ḥ. Optamos também, em certos casos, pela grafia que um leitor de língua portuguesa reconhece mais claramente, como matzah para "pão ázimo" (ao invés de mazah). 


$\begin{array}{ll}\text { Jn } & \text { Jonas } \\ \mathrm{Jr} & \text { Jeremias } \\ \mathrm{Js} & \text { Josué } \\ \mathrm{Jz} & \text { Juízes } \\ \mathrm{Lv} & \text { Levítico } \\ 1 \mathrm{Mc} & \text { 1o Livro dos Macabeus } \\ 2 \mathrm{Mc} & \text { 2o Livro dos Macabeus } \\ \mathrm{Na} & \text { Naum } \\ \mathrm{Ne} & \text { Neemias } \\ \mathrm{Nm} & \text { Números } \\ \mathrm{Os} & \text { Oséias } \\ \mathrm{Pr} & \text { Provérbios } \\ 1 \mathrm{Rs} & \text { 1o Livro dos Reis } \\ 2 \mathrm{Rs} & \text { 2o Livro dos Reis } \\ \mathrm{Rt} & \text { Rute } \\ \mathrm{Sf} & \text { Sofonias } \\ \mathrm{S} 1 & \text { Salmos } \\ 1 \mathrm{Sm} & \text { 1o Livro de Samuel } \\ 2 \mathrm{Sm} & \text { 2o Livro de Samuel } \\ \mathrm{Zc} & \text { Zacarias }\end{array}$




\section{ÍNDICE}

Agradecimentos

pg. 3

Resumo / Abstract / Palavras-Chave / Key Words

pg. 4

Transliterações, Padronizações e Abreviaturas

pg. 5

1 - Introdução

pg. 8

2 - A Teologia do Holocausto (Judaica e Cristã) - Uma Introdução

pg. 14

3 - A Ortodoxia Moderna - história e principais idéias

pg. 30

4 - Histórico dos conceitos judaicos relacionados ao Holocausto:

4.1 - Aliança

pg. 36

4.2 - História como Revelação Divina

pg. 44

4.3 - Jó

pg. 50

4.4 - Livre-Arbítrio

pg. 57

4.5 - Martírio (Kidush Ha-Shem)

pg. 62

4.6 - Ocultamento da Face (Hester Panim)

pg. 71

4.7 - Por Causa de Nossos Pecados

pg. 77

4.8 - Significado Religioso do Estado de Israel

pg. 83

4.9 - A Singularidade do Holocausto

pg. 95

5 - O Holocausto no pensamento de Joseph Soloveitchik

pg. 98

6 - O Holocausto no pensamento de Eliezer Berkovits

pg. 125

7 - O Holocausto no pensamento de Irving Greenberg

pg. 147

8 - Comparação entre os pensamentos

de Soloveitchik, Berkovits e Greenberg

pg. 173

9 - Três Elementos para Pensar a Contradição entre os Rabinos

pg. 178

10 - Conclusão

pg. 206

Apêndice: Entrevista com Irving Greenberg

pg. 213

Bibliografia

pg. 222 


\section{INTRODUÇÃO}

O Holocausto ${ }^{2}$ não ameaçou apenas a existência física dos judeus, mas também o judaísmo como religião ${ }^{3}$. O massacre do "povo escolhido" na Europa, num nível de barbárie inédita na história mundial, pareceu para muitos ter abalado as estruturas de uma fé que reivindica um especial relacionamento com um Deus definido como bom, justo e preocupado com os assuntos humanos.

Tamanha destruição não poderia passar despercebida tanto pelos pensadores quanto pelo mais simples dos fiéis, e tentativas de respostas religiosas começaram a

${ }^{2}$ Neste trabalho utilizarei indistintamente dois termos consagrados para identificar o massacre nazista de judeus entre 1933 e 1945: Holocausto e Shoá.

O termo Holocausto chegou até nós através da palavra em latim holocaustum, que por sua vez deriva da palavra grega holokaustos. Esta última é um composto da palavra holos (inteiro) e kaustos (queimado). Assim, holokaustus (e holocausto) significa "algo totalmente queimado". A Septuaginta tradução da Bíblia Hebraica ao grego - empregou o termo "holocausto" na tradução da palavra hebraica עולה (olah), que significa um tipo de oferenda a Deus que precisa ser totalmente queimada, conforme o Pentateuco. A tradução da Bíblia para o inglês (Rei James) adotou o mesmo termo "holocausto" para עולה, o que foi decisivo para a palavra passar a significar "sacrifício religioso" até a metade do século $\mathrm{XX}$.

O escritor Elie Wiesel é apontado como um dos responsáveis pela aplicação do termo holocausto ao massacre nazista, já nos anos 50, inspirado pela passagem bíblica do Sacrifício de Isaac.

Porém, a adoção do termo holocausto para identificar o massacre nazista é problemático, pois "se (os judeus) são o sacrifício do holocausto, implicitamente se segue que (os nazistas) são os sacrificadores (...) [assim] coloca-se os nazistas num papel de semi-'sacerdotes'” (Garber e Zuckerman , 1988, pg. $1881)$.

O termo em hebraico que identifica o massacre nazista é Shoá (שואה). A palavra está presente na Bíblia, mas não tem peso religioso, significando "destruição total, ruína".

Na Bíblia, o termo Shoá aparece em Sofonias 1:15, Isaías 47:11, Provérbios 1:27 e Salmos 35:8. Denota um grande desastre que acomete o indivíduo ou o coletivo como punição por seus pecados, de forma repentina e inesperada, provocando choque. O uso do termo após a Segunda Guerra Mundial reteve a idéia de um grande desastre, mas desconsiderou o conceito de pecado.

Até 1946, o termo Shoá era raramente utilizado. Em 1939, um comitê organizado para auxiliar refugiados judeus poloneses usou o termo para chamar a atenção para a inédita situação vivida. Um ano mais tarde, o livro The Shoah of Polish Jewry foi publicado na Palestina.

Mas foi apenas no verão de 1947, quando o Yad Vashem - uma instituição criada no ano anterior, na Palestina, para homenagear os mortos sob o nazismo - organizou uma conferência acadêmica intitulada "Shoah U-Gevurah" (Shoá e Heroísmo), que o termo se popularizou.

"O uso do termo Shoá indica a busca de um vocábulo especial, não usado para destruições passadas da história judaica. Sua aceitação (...) demonstra um certo entendimento que o sofrimento dos judeus durante a Segunda Guerra foi sem precedentes dentro da experiência histórica judaica" (Ofer, 1996, pg. 26).

O termo Hurban (חורבן) é o preferido por autores, especialmente ortodoxos, que não desejam dar ao massacre nazista uma conotação diferenciada em relação a outras catástrofes judaicas do passado. Estes autores negam a singularidade deste evento e, portanto, preferem usar este termo tradicional que define qualquer catástrofe contra o povo judeu em sua história.

Neste tese, evitarei o uso do termo "hurban" como sinônimo de "holocausto" ou "shoá" para não confundir com a utilização que faço do termo "literatura de hurban" nesta pesquisa.

(Garber e Zuckerman, 1988, pg. 1880, 1881, 1882, 1883 /Jakobovits, 1988, pg. 183 / Schindler, 1992,

pg. 6 / Fackenheim, 1987, pg. 399 / Caplan, 2002, pg. 145 / Ofer, 1996, pgs. 25, 26, 27.)

${ }^{3}$ Kepnes, 2000, pg. 266 / Braiterman, 1998, pg. 10. 
ser elaboradas ainda durante a Segunda Guerra Mundial, por rabinos aprisionados em guetos e campos-de-concentração. Após 1945, pensadores das mais diferentes correntes do judaísmo - ortodoxos, conservadores e reformistas -, assim como livrepensadores e acadêmicos, dedicaram-se ao tema.

Estes pensadores enfrentaram perguntas sensíveis: A Aliança de Deus com Israel foi abalada como resultado do massacre na Europa? Como esta tragédia pode ser entendida na História, um processo tradicionalmente entendido no judaísmo como sendo comandado por Deus desde a Criação até a Redenção? Modelos tradicionais judaicos, como o sofrimento de Jó, podem ser aplicados à Shoá? O nazismo teria sido um caso extremo de abuso do livre-arbítrio concedido por Deus aos homens? Houve possibilidade de martírio numa situação em que os judeus não tiveram outra alternativa senão a morte? Deus teria "ocultado Sua face" enquanto funcionavam as câmaras-de-gás e fornos crematórios? O Holocausto pode ter sido punição divina por algum pecado do povo judeu?

Outras duas importantes questões, mais modernas, também inquietaram os pensadores do Holocausto. A primeira diz respeito ao Significado Religioso do Estado de Israel, país fundado logo após o final da Segunda Guerra Mundial. O afluxo de sobreviventes do nazismo à Terra Prometida seria a realização do sonho messiânico ou este país seria uma mera entidade política de abrigo a refugiados?

A segunda questão moderna é sobre a Singularidade do Holocausto. Os pensadores judeus divergem ao comparar o genocídio nazista com outras catástrofes da história judaica. O Holocausto, perpetrado numa inédita e macabra escala industrial, pode ser equiparado a outras destruições do passado ou deve ser considerado um evento único e incomparável em toda a História?

Esta tese examinará respostas a estas questões apresentadas por três pensadores religiosos de uma corrente judaica, a Ortodoxia Moderna dos EUA. Tratase dos mais importantes pensadores ortodoxos modernos no campo das reflexões sobre o Holocausto, a saber: Joseph B. Soloveitchik (1903-1993), Eliezer Berkovits (1908-1992) e Irving Greenberg (1934-). 
Em comum, além de pertencerem a uma mesma corrente judaica, os três autores são rabinos, responsáveis por congregações religiosas e todos possuem doutorado $(\mathrm{PhD})$ por destacadas universidades da Europa e EUA. Apesar da diferença de geração entre eles ${ }^{4}$ e de certa diferença na formação ${ }^{5}$, é possível tratá-los como representantes legítimos de uma mesma corrente, a Ortodoxia Moderna norteamericana.

A necessidade de realizar um corte no universo de pesquisa (Teologia do Holocausto), concentrando-se em apenas uma corrente do Judaísmo (Ortodoxia Moderna dos EUA) deveu-se ao fato de que, desde a Segunda Guerra Mundial, já se acumulou uma vasta literatura neste campo de estudos. Para dar um exemplo, uma coletânea de reflexões religiosas sobre a Shoá, publicada em 2002, reuniu 114 autores (incluindo pensadores cristãos e excluindo ortodoxos judeus) ${ }^{6}$. Portanto, para esta tese ser bem sucedida em alcançar resultados sólidos e consistentes, fez-se necessário um corte neste universo.

A concentração do estudo na Ortodoxia Moderna tem uma atração especial para o pesquisador acadêmico. Os ortodoxos modernos são pensadores comprometidos com a tradição do judaísmo, o que nos remeterá ao estudo das fontes clássicas, ou seja, a Bíblia Hebraica e a literatura rabínica. Ao mesmo tempo, não desprezam a cultura ocidental, ao contrário de outras correntes mais conservadoras da ortodoxia. Portanto, estaremos examinando pensadores que dialogam com o judaísmo clássico, mas também com a filosofia e a ciência, o que torna-os um objeto de estudo interessante para a Academia.

Como ortodoxos, Soloveitchik, Berkovits e Greenberg invariavelmente recorreram a conceitos judaicos clássicos para aplicá-los no caso do Holocausto. São os mesmos conceitos utilizados por gerações de pensadores judeus do passado para explicar outras tragédias da história judaica. Entre estes, destacam-se: "Aliança" (a crença numa relação especial entre o povo judeu e seu Deus), "História como Revelação Divina" (interpretação de eventos históricos como o plano de Deus para

\footnotetext{
${ }^{4}$ Greenberg faz parte de uma geração posterior, em relação a Soloveitchik e Berkovits.

${ }^{5}$ Greenberg é nascido nos EUA, enquanto Soloveitchik e Berkovits, apesar de terem desenvolvido suas obras e carreiras majoritariamente em solo norte-americano, nasceram e foram educados na Europa.

${ }^{6}$ Cohn-Sherbok, 2002.
} 
seu povo e para a humanidade), "Jó" (tragédias sem lógica que assolam um indíviduo ou uma nação inocentes), "Livre-Arbítrio" (liberdade do homem para escolher entre o bem e o mal), "Martírio ou Kidush Ha-Shem" (disposição dos judeus de sacrificar suas vidas para glorificar Deus), "Ocultamento da Face ou Hester Panim" (passividade de Deus enquanto judeus são perseguidos), "Por Causa de Nossos Pecados" (catástrofes coletivas interpretadas como punição divina por transgressões do povo judeu).

Nesta tese, após os capítulos introdutórios, faremos uma exposição de cada um destes conceitos, além dos dois temas modernos trazidos pela Shoá, mencionados mais acima (Significado Religioso do Estado de Israel e Singularidade do Holocausto). Veremos como cada um destes nove elementos desenvolveram-se durante a história do pensamento judaico e quais suas características.

Assim, numa etapa seguinte, quando verificarmos como cada um dos três pensadores ortodoxos modernos aplicaram estes noves conceitos e temas para o caso do Holocausto, poderemos apreciar suas reflexões de modo mais completo. Examinaremos todas as obras relevantes destes rabinos sobre o Holocausto e apresentaremos suas posições, reorganizando-as segundo estes nove conceitos clássicos e temas modernos.

A vantagem de apresentar as reflexões dos rabinos desta maneira é que, em seguida, poderemos comparar seus pensamentos. Para isso, elaboraremos um quadroresumo, com um sumário de suas posições a respeito de cada um dos nove conceitos e temas. Ficará claro em que pontos os rabinos concordaram entre si e em quais se contradisseram. Será possível concluir se a Ortodoxia Moderna dos EUA, através de seus principais pensadores do Holocausto, apresentou a seus fiéis uma resposta unificada e harmônica ou contraditória e conflituosa.

Baseada nas constatações alcançadas até este ponto, esta tese de doutoramento encerrar-se-á com uma reflexão sobre a importância da chamada Teologia do Holocausto. Procuraremos responder às seguintes questões finais: até que ponto este conjunto de reflexões colaborou para que o judaísmo não sucumbisse à depressão e ao pessimismo após o assassinato de um terço de seus fiéis na Europa nazista? Os 
pensadores judeus proveram seus fiéis com respostas à altura da terrível catástrofe? Afinal, qual é a importância destas reflexões para o judaísmo?

Algumas decisões metodológicas adotadas nesta tese merecem esclarecimento. Nos capítulos dedicados à apresentação das reflexões de Soloveitchik, Berkovits e Greenberg, deve-se ter em mente que os três pensadores não exibiram originalmente suas reflexões do modo como estão expostas neste trabalho. Eles não organizaram suas obras baseados nos nove conceitos e temas que nortearam esta pesquisa. Apresentá-los desta maneira foi uma necessidade específica desta tese, para que pudéssemos comparar suas reflexões.

Disto decorre o fato de que foi necessário reescrever suas reflexões para adaptá-las às necessidades desta tese. Muitas vezes, suas opiniões sobre determinado assunto (Aliança, por exemplo), encontram-se espalhadas em diferentes obras. Isto envolveu um cuidadoso trabalho de reorganização da obra destes pensadores, para que o resultado final continuasse inteiramente fiel aos seus pensamentos.

Muitas vezes deparei-me com o dilema de como reconstruir o estilo literário destes autores. A questão era se deveria criar ligações editoriais artificiais para harmonizar de forma mais bela textos provenientes de diferentes obras ou se o correto seria me restringir a apresentar as idéias exatamente como se encontram nas obras originais, num estilo mais seco, porém mais fiel. Nesta tese, a decisão foi sempre privilegiar a rigorosa exatidão das idéias, mesmo que isto prejudicasse a beleza do estilo de escrita. Procurei adicionar a menor quantidade possível de elementos editoriais estranhos ao original. Como resultado, em algumas passagens, o estilo literário de um pensador poderá resultar, inadvertidamente, seco ou áspero.

Outra consequência desta reorganização de idéias é que um conceito ou tema poderá estar apresentado de forma muito mais profusa que outro. Por exemplo, no capítulo dedicado à obra de Soloveitchik, o tema "Significado Religioso do Estado de Israel" é bem mais longo que "Por Causa de Nosso Pecados". No capítulo sobre o pensamento de Greenberg, o conceito de "Povo Eleito" é bem mais extenso que o de 
"Livre-Arbítrio". Isto porque, na obra original destes rabinos, certos conceitos e temas se encontram mais desenvolvido que outros. Esta tese, ao privilegiar a rigorosa apresentação das idéias dos autores, não fez nenhum esforço para corrigir estilisticamente estas diferenças.

Uma outra decisão metodológica foi adotar uma postura maximalista em relação a todos os temas abordados na tese. Após termos feito um corte no universo de pesquisa (Teologia do Holocausto), optando por investigar apenas uma corrente do judaísmo (Ortodoxia Moderna dos EUA), a decisão foi maximizar a apresentação de todos elementos envolvidos neste trabalho.

Desta maneira, foi feito um esforço para se traduzir cuidadosamente todas as passagens talmúdicas citadas pelos pensadores ou por outras fontes. Algumas destas passagens são apresentadas pela primeira vez em língua portuguesa e sua tradução é resultado da comparação entre diferentes edições do Talmud, nas versões em hebraico e inglês.

Também seguindo a opção maximalista, a tese inclui um capítulo de introdução à Teologia do Holocausto, tanto judaica quanto cristã. Por ser um tema inédito na academia brasileira, optamos por apresentar informações gerais sobre este campo, para que esta pesquisa também possa servir de base e estímulo para o surgimento de outros trabalhos na área. 


\section{2 - A TEOLOGIA DO HOLOCAUSTO (JUDAICA E CRISTÃ) - UMA} INTRODUCÃO

\section{$\underline{2.1 \text { - Teologia Judaica do Holocausto }}$}

\section{$\underline{2.1 .1-\text { Histórico }}$}

Reflexões religiosas judaicas sobre o Holocausto surgiram durante a própria Segunda Guerra Mundial ${ }^{7}$, em obras elaboradas ainda em guetos e campos-deconcentração. Entre os iniciadores da chamada Teologia do Holocausto se destaca o rabino Kalymnous Kalmish Schapiro, que escreveu um diário com reflexões baseadas na porção semanal da Torá e no que testemunhou no Gueto de Varsóvia. Schapiro foi assassinado em novembro de 1943 e, seu diário, encontrado nas ruínas do gueto. O texto foi posteriormente editado e recebeu o título de Esh Kodesh ou אש קודש (Fogo Sagrado). Outra figura de destaque é o rabino ortodoxo húngaro Yissachar Shlomo Teichthal, que escreveu Em Habanim Smehah ou אם הבנים שמחה (A Feliz Mãe de Crianças). Esta obra foi concebida pouco antes de seu assassinato em Auschwitz e chama a atenção por sua postura pró-sionista (uma raridade entre os ortodoxos da época) ${ }^{8}$.

Porém, com o final da guerra e a tomada de consciência sobre as reais dimensões do massacre nazista, o horror e a a perplexidade tomaram conta dos pensadores judeus e um silêncio sobre o assunto perdurou durante cerca de vinte anos $^{9}$. Os maiores nomes judeus do imediato pós-guerra - como Abraham Joshua Heschel, Martin Buber, Mordecai Kaplan e o próprio Joseph Soloveitchik conseguiram tratar da Shoá apenas marginalmente em suas obras ${ }^{10}$.

\footnotetext{
${ }^{7}$ Para consultar estudos sobre as reflexões judaicas sobre a Shoá realizadas durante a própria Segunda Mundial, ver Gershon Greenberg, Pessach Schindler e Hava Eshkoli.

${ }^{8}$ Schindler, 1992.

Este livro tornou-se uma obra importante de estudo nas yeshivot do movimento ortodoxo sionista (Michman, 1996, pgs. 696 e 697).

${ }^{9}$ Sacks, 1990, pg. xx / Lipstadt, 2004, pg. 109.

${ }^{10}$ Braiterman, 1998, pg. 87.
} 
$\mathrm{O}$ acadêmico Zachary Braiterman aponta várias causas para este silêncio ${ }^{11}$. Segundo ele, os pensadores judeus que testemunharam o Holocausto teriam vivenciado um "choque psicológico", do mesmo tipo sofrido por enlutados ou pacientes terminais, que passam por um período de negação e descrença da realidade. Para estes pensadores também faltou o acesso à literatura, filmes, estudos científicos e testemunhos oculares sobre o Holocausto, que algumas décadas mais tarde inundariam a cultura ocidental e ajudariam a criar uma linguagem própria para abordar o nazismo.

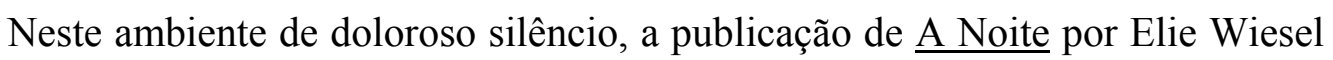
foi uma exceção. A obra apareceu em edição francesa em 1958 e, dois anos mais tarde, em inglês. É um pequeno livro de memórias, onde ele narra a vida dos judeus na Hungria antes da Shoá, a deportação de sua família, a internação em Auschwitz, a morte de familiares e sua libertação. Apesar de ser, em sua maior parte, uma biografia narrativa, há também algumas poucas reflexões religiosas, mas que marcaram profundamente toda a posterior Teologia do Holocausto. Entre as esparsas reflexões religiosas de Wiesel, destaca-se o trecho do enforcamento de uma criança ${ }^{12}$.

\footnotetext{
${ }^{11}$ Braiterman, 1998, pgs. 6 e 7.

Para Lipstadt (2004, pg. 110), o interesse pelo Holocausto a partir da década de 70, em particular nos EUA, deveu-se ao estabelecimento mais estável dos sobreviventes no país no aspecto material, quando passaram a apoiar a construção de museus e memoriais. Ela também destaca a importância da série televisiva "Holocaust", no final daquela década, que auxiliou na difusão e debate sobre o tema.

12 "O Oberkapo (...) era um holandês (...) 700 homens trabalhavam sob suas ordens (...) ele tinha um menino como assistente (...) uma criança com um rosto refinado e bonito, que não se costumava ver no campo-de-concentração (...) O pequeno assistente do holandês era amado por todos, ele tinha a face de um anjo triste (...) Um dia, a estação de energia elétrica foi explodida. A Gestapo, chamada ao local, suspeitou de sabotagem. Eles acharam uma pista, que acabou levando ao Oberkapo holandês. Após uma busca, acharam com ele um importante estoque de armas (...) Seu pequeno assistente também foi torturado (...) e os SS sentenciaram-no à morte, com dois outros prisioneiros (...) Certo dia, quando voltávamos do trabalho, vimos três forcas preparadas na praça central. Chamada geral. Os SS nos cercaram, metralhadoras prontas: a cerimônia tradicional. Três vítimas acorrentadas - entre elas o pequeno assistente, o anjo de rosto triste. Os SS pareciam mais preocupados, mais tensos que o normal. Enforcar um menino em frente a milhares de espectadores não é coisa fácil. $\mathrm{O}$ chefe do campo leu o veredito. Todos olhavam o garoto. Ele estava pálido, quase calmo, mordendo os lábios. As forcas lançavam suas sombras sobre ele. Desta vez, o Lagerkapo se recusou a atuar como executor. Três SS o substituíram. As três vítimas subiram juntas até as cadeiras. Os laços foram colocados nos três pescoços ao mesmo tempo. "Viva a liberdade", gritaram os dois adultos. Mas a criança fícou em silêncio. 'Onde está Deus? Onde Ele está?', perguntou alguém atrás de mim. Com o sinal do chefe do campo, as três cadeiras foram empurradas. Silêncio total através do campo. No horizonte, o sol se punha. 'Descubram a cabeça!', gritou o chefe do campo. Sua voz estava rouca. Nós soluçávamos. 'Cubram a cabeça!'. Então a marcha começou. Os dois adultos já não viviam. Suas línguas balançavam inchadas e azuladas. Mas a terceira corda ainda se movia. Por ser tão leve, a criança ainda estava viva. Por mais de meia hora ele continuou ali, lutando entre a vida e a morte, morrendo em lenta agonia sob nossos olhos. E tínhamos que mirá-lo diretamente na face. Ele ainda estava vivo quando passei por ele. Sua língua estava vermelha, seus olhos ainda não haviam se apagado. Atrás de mim, ouvi o mesmo
} 
Apesar do impacto desta obra de Wiesel, continuou imperando o silêncio no que diz respeito à reflexão judaica sobre o nazismo. Esta situação apenas se modificaria a partir de 1961, sob o impacto do julgamento do criminoso nazista Adolph Eichmann, em Jerusalém - um verdadeiro divisor de águas para a Teologia do Holocausto ${ }^{13}$. De assunto tabu, a Shoá foi levada ao debate público e passou a ocupar um lugar central na reflexão judaica (e do mundo ocidental em geral). Em 1966, o professor e teólogo norte-americano Richard Rubenstein publicou After Auschwitz, a primeira obra judaica em que o Holocausto aparece como tema central de reflexão.

Rubenstein tem uma história pessoal digna de nota ${ }^{14}$. Nascido numa família judia nova-iorquina em 1924, converteu-se à corrente cristã Unitarista e preparava-se para assumir funções sacerdotais quando retornou ao judaísmo. Matriculou-se no Hebrew Union College, visando tornar-se rabino reformista, mas mudou de posição e formou-se rabino conservador, aos 28 anos, através do Jewish Theological Seminary. Alguns anos depois, doutorou-se em Harvard, com tese sobre a aplicação da análise freudiana em agadot ${ }^{15}$ rabínicas.

Em After Auschwitz, Rubenstein formulou uma teologia de "morte de deus", inspirada em pensadores cristãos norte-americanos daquela época ${ }^{16}$. Rubenstein afirma ser impossível conciliar a idéia judaica tradicional de uma divindade benevolente e onipontente, que faz uma aliança com um povo escolhido, com as câmaras-de-gás nazistas. Por conta da Shoá, o pensador rejeitou conceitos clássicos do judaísmo como messianismo, ressurreição e História guiada por Deus.

Para Rubenstein ${ }^{17}$, o Holocausto evidenciou que a divindade se afastou dos assuntos humanos e não há um sentido no Cosmos. Ele propõe em seu livro uma nova

homem perguntar: 'Onde está Deus agora?'. E ouvi uma voz respondendo, vinda de dentro de mim: 'Onde Ele está? Aí está Ele - Ele está pendurado aqui nesta forca'”. (Wiesel, 1970, pgs. 74, 75, 76)

${ }^{13}$ Braiterman, 1998, pg. 162.

${ }_{15}^{14}$ Hellig, 1993, pgs 249 a 264.

${ }^{15}$ Agadah (אג), pl. agadot - "relato". Todo material não-legal (não-halákhico) da literatura rabínica. É um corpus bem variado, que inclui sermões, histórias de diferentes tipos, folclore, máximas, entre outros.

${ }^{16}$ Hellig, 1993.

${ }^{17}$ Hellig, 1993. 
religião judaica, inspirada no paganismo, de culto à natureza. O judaísmo, afirma, deve continuar existindo, pois apenas a comunidade humana dá sentido à vida.

Quase concomitante à reflexão de Rubenstein, um novo evento histórico colaborou para transformar a postura dos pensadores judeus em relação ao Holocausto: a Guerra dos Seis Dias, entre Israel e seus vizinhos árabes, em $1967^{18}$. A expressiva vitória militar israelense teve um impacto na consciência judaica ao redor do mundo, transmitindo um novo sentimento de segurança e auto-estima.

Nas palavras do acadêmico Michael Morgan, a vitória militar "liberou a memória (judaica)" 19 e os pensadores puderam, enfim, confrontar o Holocausto de maneira mais ampla. A experiência dos campos-de-concentração não mais levava a um absoluto sentimento de culpa e embaraço, e nem ameaçava ofuscar toda a tradição e o passado judaicos ${ }^{20}$. Após 1967, a humilhação das câmaras-de-gás pôde ser posicionada antes da vitória militar judaica, que parecia, à época, moralmente justificada como uma ação de auto-defesa.

A partir de então, começaram a surgir importantes reflexões sobre o Holocausto. Eliezer Berkovits completou Faith After the Holocaust logo após a Guerra dos Seis Dias. Outro pensador de destaque foi Emil Fackenheim, que publicou God's Presence in History em 1970.

Fackenheim ${ }^{21}$ nasceu na Alemanha em 1916, formou-se rabino liberal e, logo após a Noite dos Cristais (1938), foi internado durante alguns meses no campo-deconcentração de Sachsenhausen. Após sua libertação, transferiu-se para o Canadá, onde ficou preso durante um ano e meio acusado de "inimigo estrangeiro". Libertado, assumiu funções de rabino e ingressou na Universidade de Toronto, onde doutorou-se e lecionou Filosofia. Faleceu em Jerusalém, em 2003.

\footnotetext{
${ }^{18}$ Morgan, 1997, pgs 157 a 162

${ }^{19}$ Morgan, 1997, pg. 162

${ }^{20}$ Morgan, 1997,pg. 158

${ }^{21}$ Seeskin, 1993, pgs 41 a 57
} 
$\mathrm{Na}$ visão de Fackenheim ${ }^{22}$, o Holocausto, apesar de sua crueldade única na história da humanidade, não alterou as bases da fé judaica. O pensador reafirmou a existência do Deus de Israel, que redime, escolhe o povo judeu e está interessado nos assuntos humanos. A novidade em seu pensamento ${ }^{23}$ foi afirmar que, após o Holocausto, a sobrevivência judaica não é mais apenas uma esperança, mas um dever de cada indivíduo. A Shoá impôs o " $614^{\circ}$ mandamento" ${ }^{24}$ : os judeus estão proibidos de conceder a Adolf Hitler uma vitória póstuma, permitindo a extinção do judaísmo. É agora uma obrigação manter viva a religião que os nazistas pretenderam destruir ${ }^{25}$.

\section{$\underline{2.1 .2 ~-~ A ~ p o s i c ̧ a ̃ o ~ d a ~ u l t r a-o r t o d o x i a ~}$}

Os ultra-ortodoxos (haredim, em hebraico) formam um grupo à parte em relação às reflexões sobre o Holocausto. Este grupo foi especialmente atingido pelo massacre nazista, perdendo entre $80 \%{ }^{26}$ e $90 \%{ }^{27}$ de seus líderes, yeshivot ${ }^{28} \mathrm{e}$ comunidades. No entanto, a quase totalidade dos ultra-ortodoxos recusa-se a abordar teoricamente as questões levantadas pela Shoá ${ }^{29}$.

\footnotetext{
${ }^{22}$ Seeskin, 1993, idem

${ }^{23}$ Seeskin, 1993, idem

${ }^{24}$ referência aos 613 mandamentos do judaísmo tradicional, que devem ser observados por todo judeu.

${ }^{25}$ Comentaristas de Fackenheim criticaram-no por conceder a Hitler um papel tão importante no judaísmo pós-1945.

${ }^{26}$ Greenberg, 1977, pg. 8

${ }^{27}$ Jakobovits, 1988, pg. 177.

${ }^{28}$ Yeshivah (ישיבה), pl. yeshivot - do verbo hebraico "sentar". Academia rabínica.

${ }^{29}$ Immanuel Jakobovits (1921-1999), escritor e rabino-chefe da Inglaterra, de orientação ortodoxa moderna, interpretou a atitude ultra-ortodoxa de distanciamento intelectual do Holocausto como influenciada pela dificuldade desta sociedade de lidar com o tema. Ele escreveu: "Houve, e ainda existe, uma talvez natural tendência de se evitar as óbvias perplexidades teológicas colocadas inevitavelmente pelo Holocausto. Não há nada embaraçoso em admitir que evitar a constante renovação do encontro com o Holocausto através de exercícios comemorativos pode muito bem ser um mecanismo de defesa contra amplificar questões que melhor fiquem não-perguntadas (...) questões estas acentuadas ao se perceber que os mais diabólicos excessos da Solução Final foram perpetrados contra a mais florescente parte do nosso povo do ponto-de-vista espiritual" (Jakobovits, 1988, pgs. 180 e 181).

Já o acadêmico Eliezer Schweid foi em outra direção e considerou um "erro" criticar a reação ultraortodoxa à Shoá a partir de padrões intelectuais modernos. Escreve ele que, enquanto pensadores modernos apreciam respostas intelectuais, o mesmo não vale para os ultra-ortodoxos, que preferem reagir ao Holocausto em termos de organização comunitária e educação da nova geração. "Intelectualmente, as respostas judaicas modernas podem ser muito mais interesantes e sofisticadas (...) mas dificilmente podem ser consideradas mais convincentes (...) A resposta haredi (...) não foi direcionada à dimensão intelectual (...) Foi uma incrível tentativa energética de ressuscitar a existência judaica" (Schweid, 1996, pgs. 47 e 48).
} 
No Estado de Israel, a ultra-ortodoxia rejeita até hoje participar dos eventos que cercam o Yom HaShoah (Dia do Holocausto, comemorado no dia 27 do mês hebraico Nissan) ${ }^{30}$. O setor ${ }^{31}$ também demonstra pouco interesse por trabalhos acadêmicos e científicos a respeito do Holocausto, preferindo concentrar seus esforços na transmissão de relatos de comportamento religioso exemplar e piedoso durante o genocídio, marcadamente casos de martírio, com finalidade educativa.

As poucas reflexões ultra-ortodoxas sobre o Holocausto foi assinada por rabinos desconhecidos, muitas vezes em forma de folhetos com circulação restrita no interior de sinagogas. Invariavelmente, estas publicações acusam os movimentos judaicos modernos - Haskalah ${ }^{32}$, Reforma e Sionismo - como catalisadores do Holocausto. Na visão destes autores, estes movimentos "rebeldes" atraíram a ira de Deus, que puniu o povo judeu como um todo através do nazismo ${ }^{33}$.

Esta linha de pensamento teve seu melhor acabamento nas reflexões do rabino Yoel Teitelbaum (1887-1979) ${ }^{34}$, líder da seita hassídica Satmar. Reconhecido como grande autoridade rabínica nos meios ultra-ortodoxos, Teitelbaum foi um opositor ferrenho do sionismo. Em seu livro Va’yoel Moshe, partindo do princípio rabínico clássico de que "não há castigo sem pecado", ele afirmou que a Shoá foi uma punição divina contra a atitude sionista de forçar o retorno à Terra Santa antes da era messiânica. O rabino também assumiu outras posições polêmicas, como sua acusação

\footnotetext{
${ }^{30}$ Entre os ultra-ortodoxos, continua valendo a posição do rabino Avraham Yeshayahu Karelitz (18781953), uma das maiores autoridades halákhicas do século XX, também conhecido como Hazon Ish, que repudiou, logo após a guerra, o estabelecimento de uma data especial para lembrar as vítimas do nazismo. Karelitz afirmou: "A fixação de um dia de jejum pertence à categoria de decreto rabínico. Os [decretos rabínicos] que existem atualmente remontam ao tempo em que ainda existia profecia. Como, então, nós, membros de uma geração que melhor seria ficasse em silêncio, ousaríamos ter a arrogância de ponderar em estabelecer situações para gerações futuras ? Uma proposta deste tipo testificaria contra nós, como negando toda nossa culpa e baixeza, numa época em que estamos manchados por nossas iniquidades e transgressões, pobres e vazios de Torá e nus de bons feitos" (citado in Jakobovits, 1988, pg. 178).

${ }_{31}^{31}$ Schweid, 1996, pg. 48.

${ }^{32}$ Haskalah (השכלה) - derivado da palavra hebraica "cérebro, intelecto". Movimento judaico moderno favorável à abertura para a cultura européia, a partir de 1750. Inspirado pelo Iluminismo, defendeu a introdução de estudos seculares no currículo judaico, adoção de língua e vestuário ocidentais e assimilação parcial na cultura majoritária.

${ }_{33}^{33}$ Michman, 1996, pg. 682, 683, 699, 700 e 703.

${ }^{34}$ Nadler, 1982, pgs. 138, 147, 148 e 149 / Ravitzky, 2001, pg. 66, 89 e 90.
} 
de que o movimento sionista instigou anti-semitismo no mundo para provocar a imigração de judeus ao Estado de Israel ${ }^{35}$.

\section{2 - Teologia Cristã do Holocausto}

\subsection{1 - Panorama geral}

Desde o final da Segunda Guerra Mundial, dezenas de teólogos e pensadores de diferentes denominações cristãs refletiram sobre o Holocausto e seu impacto religioso ${ }^{36}$. Assim como no judaísmo, também no cristianismo as reações à Shoá resultaram num variado espectro de propostas ${ }^{37}$, que podem ser ordenadas em cinco grupos principais ${ }^{38}$ :

No primeiro grupo, estão teólogos que conservam a tradição cristã intacta. Eles não negam a existência do Holocausto, mas ignoram suas implicações para a vida e pensamento cristãos. Afirmam que a eventual cumplicidade de seus correligionários com os perseguidores nazistas não aconteceu por deficiências na teologia tradicional, mas por decisão individual ou devido a uma apreensão deficiente da verdade cristã.

\footnotetext{
${ }^{35} \mathrm{O}$ rabino manteve sua avaliação do sionismo mesmo após ter sido salvo do campo-de-concentração nazista de Bergen-Belsen graças à intervenção de políticos sionistas, que negociaram sua libertação com os alemães (Verbete "Teitelbaum", Encyclopedia Judaica, Vol. 15, 1972).

Os sucessos sociais e militares do Estado de Israel também não mudaram as idéias de Teitelbaum. Para o rabino, estas conquistas materiais mostravam que Satã estava do lado dos sionistas. "É sabido, através de escritores e livros [judeus], que toda vez que se levanta no Alto um representante para nos redimir, Satã conspira para substituir por uma redenção de mentira", declarou. Para evitar qualquer contaminação de seus discípulos com o espírito de euforia que tomou conta do Estado de Israel após a vitória na Guerra dos Seis Dias, em 1967, o rabino proibiu-os de visitar o recém-conquistado Muro das Lamentações (Ravitzky, 2001, pgs. 103 e 105).

${ }^{36}$ Entre os teólogos e pensadores cristãos que refletiram sobre o Holocausto destacam-se: Gregory Baum, Eberhard Bethge, Paul van Buren, Stephen T. Davies, A. Roy Eckardt, Alice L. Eckardt, Robert Everett, Eugene Fisher, Stephen R. Haynes, Monika Hellwig, Gareth Lloyd Jones, Franklin H. Littell, Michael McGarry, Johann Baptist Metz, James Fraser Moore, Franz Mussner, John K. Roth, Rosemary Radford Ruether, Dorothee Soelle, David Tracy, Clark Williamson.

${ }^{37}$ Moore, 1988, pg. 213.

${ }^{38}$ Esta classificação é um amálgama dos modelos propostos por Moore (1988, pgs. 212 a 224) e Haynes (2002, pgs. 73 a 77).
} 
O segundo grupo de teólogos afirma uma maior implicação da Shoá para a vida cristã, mas nem o Holocausto nem a relação com o judaísmo se tornaram dominantes em suas reflexões. Preferem considerar o nazismo no mesmo nível de outras ameaças inerentes à modernidade, como o perigo atômico, a opressão da mulher, a discriminação contra os negros e a vitimização dos países terceiromundistas. Este grupo inclui de liberais a radicais, feministas e pensadores ligados à Teologia da Libertação.

O terceiro grupo enfatiza a urgência de se aprimorar a relação com o judaísmo por conta do Holocausto. Neste sentido, afirmam que as duas tradições de aliança judaica e cristã - devem ser consideradas igualmente válidas, reconhecendo a aliança de Deus com os judeus no Sinai ao lado da aliança estendida aos gentios através de Jesus Cristo. Para eles, todo discurso teológico pós-Holocausto que quebra a relação com o judaísmo ou anula sua validade é uma distorção. Este grupo também se destaca por se esforçar em redescobrir as raízes judaicas do cristianismo.

Já o quarto grupo afirma a necessidade de se revisar a tradição cristã como consequência do Holocausto. Para estes teólogos, o massacre nazista levantou questionamentos sobre elementos essenciais do cristianismo, como o anti-judaísmo presente no Novo Testamento. Apesar do NT não ser considerado por este grupo uma causa direta do Holocausto, seus integrantes afirmam que foi fator-chave na criação de um contexto receptivo que desembocaria na Solução Final. Estes teólogos apontam para "ambiguidades" na base do cristianismo, como certas passagens em textos cristãos que criam animosidade em relação aos judeus e que, portanto, levantam dúvidas sobre sua origem divina.

O quinto grupo propõe uma revisão ainda mais radical do cristianismo. Aqui não se trata apenas de apontar "ambiguidades" na base do cristianismo, mas de afirmar claramente que há erros na tradição cristã que devem ser eliminados. Como afirma a teóloga católica Rosemary Radford Ruether, o anti-judaísmo é simplesmente a "outra face" da cristologia ${ }^{39}$. Daí esta pensadora, juntamente com outros membros

\footnotetext{
${ }^{39}$ Ruether, em seu livro "Faith and Fratricide - The Theological Roots of Anti-Semitism", citado in Moore, 1988, pgs. 212 a 224 e in Davies, 1994, pg. 351..
} 
deste grupo, proporem uma reestruturação do próprio núcleo da tradição cristã, para "purificá-la" de seu anti-judaísmo.

Quanto a respostas institucionais cristãs ao Holocausto, um elemento que une as principais igrejas foi o abandono do esforço em converter os judeus. Revertendo uma atitude que predominou durante dois milênios, as mais importates organizações cristãs decidiram eliminar a atividade missionária junto ao judaísmo, como resultado de uma maior sensibilidade após o massacre nazista.

Assim, o Conselho Mundial de Igrejas, uma entidade ecumênica que agrega diferentes denominações cristãs ${ }^{40}$, decidiu retirar a questão judaica do seu Conselho Missionário Internacional, transferindo-a para seu Comitê sobre a Igreja e o Povo Judeu. Também a Igreja Católica, durante o Concílio Vaticano II, retirou a questão judaica de sua Comissão sobre a Atividade Missionária ${ }^{41}$.

Outra atitude marcante das igrejas cristãs como resultado do Holocausto foi o reconhecimento do judaísmo como uma religião autêntica. Isto contrasta com uma tradição cristã de dois mil anos de negação de uma essência verdadeira para a fé judaica $^{42}$.

Como notou Gregory Baum, acadêmico e teólogo católico envolvido no diálogo ecumênico, estas duas atitudes - cessação dos esforços em converter judeus e reconhecimento do judaísmo - foram tomadas sem que haja ainda uma nova base teológica no cristianismo para ampará-las. "Temos aqui um caso, frequentemente encontrado na história da Igreja, em que uma decisão prática da parte das igrejas, em resposta a um evento significativo, precede a reflexão dogmática e, de fato, torna-se o guia para um futuro desenvolvimento doutrinal", escreve ${ }^{43}$.

\footnotetext{
${ }^{40}$ O World Council of Churches, fundado em 1948, representa cerca de 550 milhões de cristãos, incluindo a maioria das igrejas protestantes e ortodoxas. Não fazem parte da organização a Igreja Católica e os Batistas Sulistas dos EUA.

${ }^{41}$ Baum, 1977, pg. 113.

${ }^{42}$ Baum, 1977, pg. 113.

${ }^{43}$ Baum, 1977, pg. 113. Ver também pg. 116.
} 
De um modo geral, a reação das igrejas protestantes ao Holocausto, embora positiva, foi considerada mais espontânea que sistemática ${ }^{44}$. Já a Igreja Católica influenciou-se profundamente pela Shoá, assumindo um papel de vanguarda, especialmente na abertura de um inédito diálogo entre cristãos e judeus.

\subsection{2 - Igreja Católica}

De baluarte do anti-judaísmo durante dois milênios, a Igreja Católica transformou-se após o Holocausto na principal força cristã propulsora de diálogo e normalização do relacionamento entre as duas religiões. O momento decisivo aconteceu durante o pontificado de João XXIII, com a inauguração do Concílio Vaticano II, em $1962^{45}$.

Após três anos de intensas deliberações e negociações, o concílio aprovou o documento "Declaração sobre a Relação da Igreja com as Religiões Não-Cristãs", também conhecido como "Nostra Aetate" (devido a suas palavras iniciais, "Em nosso tempo"). Esta declaração liberal e pioneira incentivou os católicos a dialogarem com a religiões mundiais, especialmente o judaísmo. Dos cinco capítulos da "Nostra Aetate, 46 , o maior deles (o quarto) é dedicado aos judeus.

Por um lado, a Nostra Aetate reafirmou elementos tradicionais da teologia cristã em relação ao judaísmo: a aliança entre Deus e os judeus é chamada de "antiga"; sugere a conversão dos judeus ao cristianismo num futuro messiânico; reafirma que a Igreja é o novo Povo de Deus.

Mas, por outro lado, o documento rompeu de maneira revolucionária a milenar desconfiança mútua quando declarou que Jesus, os apóstolos e seus primeiros discípulos eram judeus; convidou os judeus a um diálogo fraterno; refutou a acusação de deicídio contra os judeus; condenou o anti-semitismo.

\footnotetext{
${ }^{44}$ Haynes, 2000, pg. 183.

${ }^{45}$ Obrecht, 2000, pg. 174.

${ }^{46}$ Citado in Bea, 1966, pgs. 147 a 153.
} 
Há ainda um outro aspecto da "Nostra Aetate" que merece atenção. Segundo o Cardeal Augustin Bea, organizador do concílio, o Holocausto foi a força-motriz na decisão da Igreja de promulgar a documento ${ }^{47}$. A idéia inicial, transmitida ao cardeal pelo Papa João XXIII, era redigir uma declaração que trataria exclusivamente do relacionamento com o judaísmo ${ }^{48}$. Daí um primeiro esboço do documento, apresentado ao concílio em 1963, ter trazido apenas três linhas com referências a outras religiões não-cristãs, enquanto o restante dizia respeito apenas aos judeus ${ }^{49}$. Foi apenas por conta de pressões várias de membros do concílio que a declaração expandiu-se para abrigar referências também ao hinduísmo, islamismo e budismo ${ }^{50}$. Em seu formato final, a "Nostra Aetate" representou uma extraordinária mudança de postura da Igreja Católica ${ }^{51}$, ao realizar uma auto-crítica sobre sua atividade missionária, reconhecer o pluralismo religioso e recomendar o diálogo. Neste sentido, talvez seja possível afirmar que o Holocausto não mudou apenas o relacionamento da Igreja com o judaísmo, mas também provocou uma transformação profunda do catolicismo em relação às demais religiões mundiais.

O espírito de conciliação da "Nostra Aetate" ganhou um novo impulso na década seguinte através do Papa João Paulo II, que elevou o relacionamento com o judaísmo a tema central de seu pontificado (1978-2005) ${ }^{52}$. Através de atos e declarações extraordinárias (ver cronologia abaixo), ele quebrou tabus e sedimentou uma nova era de aproximação entre as duas religiões.

Para marcar o final do milênio, o Papa supervisionou a publicação de um documento destinado a explicitar a postura do Vaticano em relação ao Holocausto, intitulado "Nós Lembramos: Uma Reflexão sobre a Shoá" (1998). A questão central ${ }^{53}$ que o documento coloca é se a perseguição nazista aos judeus teve ligação com atitudes anti-judaicas cristãs do passado.

\footnotetext{
${ }^{47}$ Bea, 1966, pg. 7.

${ }^{48}$ Bea, 1966, pgs. 7, 22 e 23.

${ }^{49}$ Bea, 1966, pg. 24.

${ }^{50}$ Bea, 1966, pg. 24.

${ }^{51}$ Baum, 1977, pgs. 114 a 116.

${ }^{52}$ Obrecht, 2000, pg. 178.

${ }^{53}$ Dulles, 2001, pg. 12.
} 
Para responder, o documento faz um balanço histórico do relacionamento entre cristãos e judeus, classificando-o como "tormentoso e bastante negativo". Começa apontando para a oposição "ocasionalmente violenta" dos judeus contra o cristianismo nascente, citando de passagem a crucificação de Jesus ${ }^{54}$. Em seguida, o documento reconhece a "discriminação generalizada" contra os judeus em países cristãos através dos séculos, vítimas de "violência, pilhagem e mesmo massacres" 55 . Também admite a existência de um anti-judaísmo cristão no nível das idéias ${ }^{56}$.

Porém, o documento distancia a Igreja Católica destas ações históricas antijudaicas, assim como do nazismo ${ }^{57}$. Preconceitos e atividades contra os judeus, em particular na Segunda Guerra Mundial, são imputados a indíviduos cristãos, mas não à instituição cristã ${ }^{58}$. O nazismo é considerado no documento como um fenômeno neopagão, com "raízes fora do cristianismo" ${ }^{59}$. O texto ainda afirma que a perseguição nazista foi condenada à época tanto pela Igreja alemã quanto pelos papas Pio XI e Pio XII ${ }^{60}$.

Após sua promulgação, o documento foi recebido com frieza por setores judaicos, que afirmaram terem esperado uma auto-crítica mais incisiva ${ }^{61}$. Como resposta, o cardeal Avery Dulles escreveu que o Vaticano não pretendeu apresentar uma declaração definitiva sobre o tema, mas sim dar mais um passo em direção à conciliação entre as duas religiões ${ }^{62}$. O cardeal também afirmou que havia um temor na Igreja de que um mea culpa mais aberto fosse utilizado de forma distorcida como propaganda por elementos anti-católicos, daí uma "certa ambivalência" no texto ${ }^{63}$.

Por fim, o cardeal explicitou uma idéia teológica católica básica que deveria ser entendida no documento. Membros da hierarquia católica, incluindo padres, bispos, cardeais e até mesmo papas, podem cometer erros e pecados, incluindo o

\footnotetext{
${ }^{54}$ Dulles, 2001, pg. 12.

${ }^{55}$ Dulles, 2001, pg. 13.

${ }^{56}$ Dulles, 2001, pgs. 15, 16. e 17

${ }^{57}$ Dulles, 2001, pg. 13.

${ }^{58}$ Dulles, 2001, pgs. 15 e 16.

${ }^{59}$ Dulles, 2001, pg. 16.

${ }^{60}$ Dulles, 2001, pgs. 14 e 15.

${ }^{61}$ Dulles, 2001, pg. 81.

${ }^{62}$ Dulles, 2001, pgs. 66 e 68.

${ }^{63}$ Dulles, 2001, pg. 56.
} 
apoio ao anti-judaísmo. Porém, a Igreja como instituição, será sempre considerada sagrada e imaculada, livre de erros. Se cristãos cometeram o pecado de perseguir judeus na época nazista, fizeram-no por terem se afastado dos princípios da Igreja, que são perfeitos. "Quando eles pecam, não o fazem porque são católicos, mas apesar do fato de serem católicos", escreve Dulles ${ }^{64}$.

\subsection{3 - $\underline{\text { Cronologia }}$}

Estes foram os principais momentos da teologia cristã no que se refere ao Holocausto ${ }^{65}$ :

19 de Outubro de 1945 - Seis meses após a rendição do exército alemão, a Igreja Evangélica da Alemanha edita a Declaração de Culpa de Stuttgart, onde afirma: "Nós nos acusamos por não termos testemunhado mais corajosamente, rezado com mais fé, acreditado mais alegremente, amado mais ardentemente".

Agosto de 1947 - Durante uma conferência judaico-cristã na Suíça, redige-se o documento "Dez Pontos de Seeligsberg", um inédito ataque institucional contra o anti-semitismo. O documento esboça passos que institituições cristãs deveriam tomar para erradicar de seu ensinamento imagens negativas dos judeus.

1948 - A primeira Assembléia do Concílio Mundial Protestante de Igrejas acontece na Holanda. Reconhece-se que naquele país "110 mil judeus foram capturados para serem mortos", mas não há menção de responsabilidade cristã por este sofrimento.

1953 - O teólogo protestante Paul Tillich propõe um amplo programa para eliminar o anti-judaísmo do ensinamento cristão. Isto incluiria enfatizar o Antigo Testamento; abandonar a missão de conversão dos judeus; encorajar o diálogo teológico; aceitar a autenticidade da fé judaica.

\footnotetext{
${ }^{64}$ Dulles, 2001, pgs. 56 a 58.

${ }^{65}$ Rittner, 2000, pgs. 17 a 28 / Roth, 2000, pg. 9 / Obrecht, 2000, pgs. 174, 175, 176 e 177 / Fisher, 2000, pgs. 180 e 181 / Rudin, 2000, pg. 217 / Isaac, 1965, pgs. 3 a 15 / Bea, 1966, pgs. 15, 16 e 22 / Dulles, 2001, pgs. 53, 67 e 68.
} 
Semana Santa, 1959 - O Papa João XXIII decreta a eliminação da palavra "pérfidos" em relação aos judeus.

1960 - O acadêmico judeu-francês Jules Isaac reúne-se com o Papa João XXIII. Sobrevivente do Holocausto, Isaac pede mudanças no que chama de "ensino do desprezo" em relação ao povo judeu.

11 de Outubro de 1962 - O Papa João XXIII inaugura o Concílio Vaticano II, com a presença de mais de 2200 bispos de vários países do mundo. Eruditos protestantes e judeus são convidados para participar como observadores oficiais.

28 de Outubro de 1965 - O Papa Paulo VI, que assumiu o pontificado após a morte de João XXIII, aprova a "Declaração sobre a Relação da Igreja com as Religiões NãoCristãs" (Nostra Aetate), documento revolucionário no relacionamento entre cristãos e judeus.

No mesmo dia, a Igreja Católica proíbe o culto a Simão de Trento, que durante mais de 500 anos foi reverenciado como mártir de crime ritual executado por judeus.

16 de Outubro de 1978 - O cardeal Karol Wojtyla assume o pontificado, adotando o nome Papa João Paulo II.

1980 - Um sínodo da Igreja Evangélica da Alemanha, realizado na região do Reno, aprova declaração reconhecendo pela primeira vez "co-responsabilidade cristã e culpa pelo Holocausto".

13 de Abril de 1986 - O Papa João Paulo II visita a Grande Sinagoga de Roma e descreve os judeus como "nossos irmãos mais velhos na fé".

1987 - A Igreja Presbiteriana dos EUA, através do documento "Um Entendimento Teológico da Relação entre Cristãos e Judeus”, afirma que a Aliança de Deus com os judeus continua existindo.

1993 - O Vaticano e o Estado de Israel assinam o “Acordo Fundamental”, que leva ao reconhecimento mútuo oficial. 
7 de Abril de 1994 - O rabino-chefe de Roma é convidado pela primeira vez na história para co-oficiar um serviço público no Vaticano. Também fatos inéditos, um cantor litúrgico judeu se apresenta na capital mundial do catolicismo e o coro do Vaticano, que existe há 500 anos, canta um texto em hebraico.

1994 - A Igreja Luterana Evangélica dos EUA adota documento onde reconhece o anti-semitismo no pensamento de Martinho Lutero.

1994 - A Conferência dos Bispos da Hungria emite declaração de arrependimento pelo Holocausto. Esta iniciativa será seguida nos anos seguintes por afirmações semelhantes de conferências episcopais de outros países europeus e dos EUA.

Janeiro de 1995 - Os bispos católicos da Alemanha, em preparação para a comemoração dos 50 anos do fim da Segunda Guerra Mundial, declaram que a "Igreja que nós proclamamos sagrada e que honramos como um mistério também é uma Igreja pecadora e em necessidade de conversão". Em abril, afirmam que a Igreja falhou em intervir durante a ascenção do nazismo.

1995 - Os bispos católicos da Holanda ecoam declarações anteriores dos bispos da Polônia e Alemanha e reconhecem "co-responsabilidade na perseguição contra judeus no passado".

16 de Março de 1998 - A Comissão do Vaticano para as Relações Religiosas com o Povo Judeu publica o documento "Nós Lembramos: Uma Refexão sobre a Shoá".

23 de Março de 2000 - Durante visita a Jerusalém, o Papa João Paulo II coloca no Muro das Lamentações uma cópia de sua prece pública "Confisssão de Pecados contra Israel”, realizada no mesmo mês na Basílica de São Pedro. Nesta prece, apesar de não mencionar o Holocausto, o papa pede aos cristãos que "reconheçam os pecados cometidos por não poucos contra o povo da aliança e das bençãos, e assim purifiquem seus corações". 
10 de Setembro de 2000 - Um grupo de 170 eruditos judeus norte-americanos publica um anúncio de página inteira no "The New York Times" afirmando que ocorre uma melhora sem precendentes nas relações entre judeus e cristãos. A respeito do Holocausto, embora o texto afirme que cristãos em demasia participaram ou foram simpáticos às atrocidades nazistas, também se afirma que "o nazismo em si não foi uma consequência inevitável do cristianismo; se o extermínio nazista dos judeus tivesse sido completamente bem-sucedido, teria voltado em seguida sua fúria assassina mais diretamente contra os cristãos". 


\section{3 - A ORTODOXIA MODERNA - HISTÓRIA E PRINCIPAIS IDÉIAS}

Até o século XVII ${ }^{66}$, os judeus europeus viviam completamente separados de seus vizinhos cristãos, tanto fisicamente (em bairros diferenciados) quanto culturalmente. Falavam uma língua diferente (idish ou ladino), frequentavam escolas próprias, vestiam roupas distintas, além de possuírem mentalidade e valores específicos. A observância de leis religiosas, como a kashrut ${ }^{67}$, impedia a convivência com o mundo não-judeu e este isolamento era aumentado ainda mais por um anti-semitismo generalizado e virulento.

Mas, aos poucos, novos ventos começaram a soprar no mundo europeu. $\mathrm{Na}$ Itália, um livro anônimo, provavelmente de autoria do rabino Leon da Modena (15711648), sugeria a anulação ou pelo menos simplificação das leis da kashrut, o relaxamento das leis do shabat ${ }^{68}$ e a suspensão da proibição de beber vinho com nãojudeus ${ }^{69}$. Na Inglaterra, era o filósofo John Locke (1632-1704) quem pedia pioneiramente em sua "Letter Concerning Toleration" igualdade de direitos aos judeus, uma idéia também esposada pelo pensador francês Jean Jacques Rousseau (1712-1778) ${ }^{70}$. Estes foram alguns tímidos passos iniciais de abertura, mas que rapidamente ganharam força e acabaram por levar o judaísmo "a uma transformação nunca vista em toda a sua longa história" ${ }^{71}$.

A grande figura do movimento de abertura dos judeus ao mundo moderno foi Moses Mendelssohn (1729-1786), na Alemanha, influenciado pelo Iluminismo. Ao mesmo tempo religioso e admirador dos valores culturais europeus, ele defendeu uma abertura que não provocasse a quebra na fé ancestral. Seu movimento fez grande sucesso na Europa e foi ainda fortalecido pela Emancipação - a concessão de direitos civis aos judeus -, a partir da Revolução Francesa ${ }^{72}$. Os dois movimentos Iluminismo cultural e Emancipação política - se reforçaram mutuamente. Pela

\footnotetext{
${ }^{66}$ Patai, 1996, pg. 223 / Heilman, 1989, pgs. 9 e 10.

${ }^{67}$ Kashrut (כשרות), adj. kasher - derivado da palavra hebraica "adequado, apropriado". Conjunto das leis alimentícias do judeu religioso. Está baseado no Pentateuco, mas foi ampliado pelos rabinos.

${ }^{68}$ Shabat (שבת) - do verbo hebraico "cessar, descansar". O sétimo dia da semana, quando o judeu religioso deve descansar e se abster do trabalho.

${ }^{69}$ Patai, 1996, pg. 225.

${ }^{70}$ Patai, 1977, pgs. 234 e 237.

${ }^{71}$ Patai, 1977, pg. 222.

${ }^{72}$ Patai, 1977, pgs. 242 e.d. / Patai, 1996, pgs. 222 e 223 / Baron, 1956, pgs. 315 e 323.
} 
primeira vez na história do Exílio, os judeus foram formalmente declarados cidadãos de seus países, com os mesmos direitos e deveres que seus compatriotas não-judeus ${ }^{73}$.

Porém, o equilíbrio idealizado por Mendelssohn entre a entrada na cultura européia e a manutenção do judaísmo não ocorreu nas gerações seguintes. Em número crescente, os judeus emancipados se dedicavam a aprender as línguas modernas, ler literatura contemporânea e absorver os costumes dominantes, ao mesmo tempo em que abandonavam as crenças religiosas ${ }^{74}$. Houve uma profunda quebra na unidade judaica, com "centenas de milhares" 75 de deserções ou conversões ao cristianismo (nenhum neto de Mendelssohn permaneceu judeu ${ }^{76}$ ).

Foi justamente ${ }^{77}$ para fazer face a esta situação de apatia e tentar dar um sustento religioso ao novo judeu europeu, que surgiu o movimento de Reforma do judaísmo. Seus primeiros passos ocorreram na Alemanha, no início do século XIX, quando começou-se a ouvir pela primeira vez nas sinagogas elementos estranhos ao ritual judaico, como coros de meninos, acompanhamento de órgão e sermões na língua local. Também, de forma inovadora, os reformistas da cidade de Hamburgo publicaram um livro de rezas que trazia mudanças na liturgia, eliminando ou atenuando os trechos mais nacionalistas judaicos, como o desejo de retorno à Terra de Israel. Naqueles tempos de idealismo e radicalismo reformista, sugeriu-se inclusive a transferência do descanso semanal judaico de sábado para domingo.

Estas inovações ${ }^{78}$ foram logo combatidas por segmentos conservadores da sociedade judaica, que primeiro se opuseram ao Iluminismo e, depois, à Reforma. Alguns rabinos tradicionalistas, pressentindo a ameaça à antiga ordem, chegaram a fazer campanha junto a governantes europeus contra a concessão de direitos civis aos judeus. Definiam-se como contrários às tendências modernizadoras, seguidores

\footnotetext{
${ }^{73}$ Patai, 1977, pgs. 242 e.d. / Patai, 1996, pgs. 222 e 223 / Baron, 1956, pgs. 315 e 323.

${ }^{74}$ Meyer, 1987, pg. 256.

${ }^{75}$ Patai, 1977, pg. 273.

${ }^{76}$ Patai, 1977, pg. 178.

${ }_{77}^{77}$ Meyer, 1987, pgs. 256 e.d.

${ }^{78}$ Katzburg, 1974, pgs. 1486, 1487, 1489, 1490, 1491 / Wurzburger, 1974, pgs. 1487 a 1489 e 1492 / Heilman, 1982, Part I, pgs. 25, 26 e 27 / Rackman, 1987, pgs. 679 e 680.
} 
incondicionais da halakhah ${ }^{79}$ e crentes no caráter divino da lei escrita (Bíblia Hebraica) e da lei oral (tradição rabínica). A partir de $1795^{80}$, esta ala tradicionalista passou a ser chamada de "ortodoxia" 81.

$\mathrm{Na}$ Alemanha, que abrigava uma grande comunidade judaica (cerca de 500 mil pessoas), a grande maioria dos judeus permaneceu ortodoxa até meados do século XIX. Isto só mudou a partir de 1860, quando todos os europeus sentiram as consequências do processo de industrialização. Assim como seus vizinhos cristãos, também os judeus deixaram para trás seus vilarejos e migraram para as grandes cidades, em busca de melhores oportunidades. A velha ordem se rompeu, iniciou-se uma busca generalizada por escolaridade científica e os que eram antes membros de sociedades fechadas, tornaram-se agora indivíduos livres no mercado de mão-de-obra. Os judeus aderiram com entusiasmo à nova ordem e, na virada do século, os ortodoxos já eram minoria na Alemanha ${ }^{82}$.

A própria ortodoxia ${ }^{83}$ se dividiu, sob influência dos novos tempos. Enquanto uma ala permanecia ativamente conservadora, outra se mostrava aberta a incorporar elementos da modernidade na estrutura do judaísmo. Esta facção modernizadora ${ }^{84}$ teve como um de seus precursores o rabino Isaac Bernays (1792-1849), em Hamburgo. Bernays - cuja neta, Martha, casou-se com Sigmund Freud - inovou ao complementar sua educação na Faculdade de Filosofia da Universidade de Wurzburg. Também chamou a atenção por vestir roupas ocidentais e, em seus sermões, expressar-se em língua alemã e incorporar temas da Filosofia, Literatura e Mitologia.

\footnotetext{
${ }^{79}$ Halakhah (הלכה), pl. halakhot, adj. aportuguesado halákhico - do verbo hebraico "andar, caminhar". Conjunto das leis religiosas judaicas, baseado na legislação presente na Bíblia Hebraica e ampliado e codificado pelos rabinos. Estudar a halakhah é um dever religioso supremo no judaísmo rabínico.

${ }^{80}$ Alguns autores preferem a data 1807.

${ }^{81}$ O sociólogo Samuel Heilman defende a idéia de que também os ortodoxos são um produto da modernidade. Baseando-se na obra de Peter Berger, Heilman afirma que uma das características centrais da era moderna é a ampliação da liberdade de escolha. No caso judaico, até o Iluminismo e a Emancipação, os judeus aderiam ao estilo-de-vida tradicional de forma automática, por força do costume e das circunstâncias. Mas, na época moderna, ser religioso passa a ser uma entre várias opções disponíveis ao indivíduo judeu. Nesta situação, se alguém decide livremente permanecer ligado à tradição, assim o faz como um indivíduo moderno (Heilman, 1982, Part I, pg. 24 / Heilman, 1989, pgs. 15 e 16).

${ }_{82}^{82}$ Graupe, 1978, pgs. 167 e 186 / Heilman, 1989, pgs. 7 e 8.

${ }^{83}$ Heilman, 1982, Part I, pg. 26.

${ }^{84}$ Samet, 1974, pg. 956 / Heilman, 1982, Part I, pgs. 34, 36 e 38.
} 
Porém, foi seu discípulo, o rabino Samson Raphael Hirsch (1808-1888) ${ }^{85}$, quem cristalizou a fusão de ortodoxia com modernidade. Nascido em Hamburgo e educado no judaísmo tradicional, complementou seus estudos na Universidade de Bonn, durante um ano, onde estudou Línguas Clássicas, História e Filosofia. Em 1851, foi convidado a servir como rabino de uma comunidade ortodoxa de Frankfurt, cargo que exerceu durante 37 anos, até sua morte. As instituições educacionais que criou nesta cidade corporificaram sua visão de mundo, que ficou conhecida como Neo-Ortodoxia.

Nas escolas de Hirsch ${ }^{86}$, estudava-se Talmud, Bíblia Hebraica e halakhah, mas também Grego, Alemão, Francês, Latim, História, Física, Matemática e Geografia. Hirsch resumiu seu ideal educacional numa frase da Mishnah ${ }^{87}$ : יפה תלמוד תורה עם דרך ארץ que traduziu livremente como “o estudo da Torá é excelente quando combinado com educação secular" ${ }^{88}$. Seu lema e modelo educacional fizeram sucesso e foram repetidos por toda a Alemanha e também no exterior.

A partir de Hirsch, firmou-se uma ala no judaísmo - agora chamada de Ortodoxia Moderna - que, por um lado, recusa alterações circunstanciais na halakhah e insiste na observância de todos os detalhes das leis e rituais judaicos. Mas, por outro lado, interessa-se pela educação secular, com muitos de seus membros frequentando universidades ${ }^{89}$. Resumindo o ideário ortodoxo moderno, um de seus mais célebres seguidores, o rabino Joseph B. Soloveitchik, afirmou que "apenas a integração do cérebro científico com o coração que procura e anseia o Deus vivo fará evoluir o ser humano" 90 .

\footnotetext{
${ }^{85}$ Katz, 1974, pgs. 508 a 514 / Liberles, 1985, pgs. 113, 114 e 133 / Graupe, 1978, pgs. 171, 172, 173 e 174 / Heilman, 1982, Part I, pgs. 41, 42 e 43.

${ }^{86}$ Katz, 1974, pgs. 508 a 514 / Liberles, 1985, pgs. 113, 114 e 133 / Graupe, 1978, pgs. 171, 172, 173 e 174 / Heilman, 1982, Part I, pgs. 41, 42 e 43.

${ }^{87}$ Mishnah (משנה) - do verbo hebraico "repetir, estudar". Obra-prima do judaísmo rabínico. Baseada na tradição oral dos fariseus, foi editada por volta do ano 200 por Yehuda Ha-Nasi. Constituída basicamente por assuntos legais, clarificou, complementou e sistematizou os mandamentos da Bíblia Hebraica. A literatura rabínica legal que se seguiu, incluindo o Talmud, está fundamentada na Mishnah.

${ }^{88}$ Tratado Avot 2:2. A tradução mais fiel ao original é: "o estudo da Torá é excelente combinado com uma profissão mundana".

${ }^{89}$ Graupe, 1978, pg. 175.

${ }^{90}$ Soloveitchik, 1979, pg. 155.
} 
A Ortodoxia Moderna ${ }^{91}$ chegou nos EUA em 1886, quando foi fundada a yeshivah Etz Chaim, em Nova Iorque. Destinada a atender imigrantes vindos da Europa Oriental, destacava-se das demais yeshivot por oferecer também educação básica secular. Onze anos mais tarde, um grupo de pais e estudantes da Etz Chaim organizou o Seminário Teológico Rabino Isaac Elkhanan, destinado a dar continuidade educacional aos formandos da yeshivah. Além de rabinos, o seminário também formou médicos, jornalistas, acadêmicos, comerciantes e empresários.

Em 1908, estudantes do seminário ${ }^{92}$ organizaram uma greve para exigir o fortalecimento dos estudos seculares. Os diretores assumiram uma posição conciliadora e permitiram que os alunos frequentassem escolas públicas e universidades no período noturno. Sete anos mais tarde, a combinação de judaísmo e estudos seculares já era um fato consumado no seminário e, numa postura inovadora, a instituição declarou oficialmente que seu propósito era conciliar "judaísmo ortodoxo e americanismo".

Estas mudanças ${ }^{93}$ ocorreram sob a presidência do rabino Bernard Revel. Nascido na Lituânia, onde adquiriu formação ortodoxa clássica, fez mestrado na New York University e doutorado no Dropsie College. Percebendo que a maior parte da ortodoxia norte-americana não desejava se isolar, e sim compartilhar das oportunidades oferecidas pelo país, Revel transformou o seminário numa instituição universitária, a Yeshiva College. Também introduziu no currículo práticas esportivas, algo impensável até então em instituições ortodoxas. Ao mesmo tempo, atraiu para o corpo docente renomados eruditos formados em yeshivot da Europa Oriental, entre eles o rabino Moses Soloveitchik e, mais tarde, seu filho, Joseph B. Soloveitchik.

Nos anos seguintes, a instituição continuou a crescer ${ }^{94}$, transformando-se no imediato pós-guerra na Yeshiva University, a mais importante instituição da

\footnotetext{
${ }^{91}$ Heilman, 1982, Part II, pgs. 184, 185 e 186 / Raphael, 1984, pgs. 141 e 142 / Waxman, 2003, pg. 411.

${ }^{92}$ Heilman, 1982, Part II, pgs. 184, 185 e 186 / Raphael, 1984, pgs. 141 e 142 / Waxman, 2003, pg. 411.

${ }^{93}$ Heilman, 1982, Part II, pgs. 185, 188, 189, 190, 191 e 192 / Raphael, 1984, pgs. 142 e 143 /

Waxman, 2003, pg. 411.

${ }^{94}$ Raphael, 1984, pgs. 144, 145 e 146 / Waxman, 2003,pg. 411 / http://www.yu.edu.
} 
Ortodoxia Moderna dos EUA ${ }^{95}$. Atualmente, além de departamentos de Judaísmo, esta universidade inclui faculdades de Medicina, Advocacia, Assistência Social e Psicologia. São cerca de 7 mil estudantes e 4.700 funcionários, entre professores e pessoal administrativo.

Hoje, a Ortodoxia Moderna dos EUA também contrasta com a ala ortodoxa conservadora por ser mais aberta ao diálogo com outros ramos do Judaísmo, os reformistas e conservadores ${ }^{96}$. Além disso, de modo geral, os ortodoxos modernos identificam-se mais com o Estado de Israel, considerando o país como portador de significado religioso e centro espiritual do povo judeu (em contraste, os ortodoxos tradicionalistas abrigam uma minoria claramente anti-sionista e uma maioria que não atribui significado religioso algum ao sionismo) ${ }^{97}$.

\footnotetext{
${ }^{95}$ Greenberg, 1998, pg. 152.

${ }^{96}$ Liebman, 1979, pg. 22.

${ }^{97}$ Waxman, 2003, pg. 410.
} 


\section{4 - HISTÓRICO DOS CONCEITOS JUDAICOS RELACIONADOS AO} HOLOCAUSTO

\section{$\underline{4.1 \text { - ALIANCCA (ברית) }}$}

\section{O massacre nazista colocou em dúvida o status dos judeus como "povo eleito"?}

Pelo menos até o Holocausto, a doutrina da Eleição de Israel constituiu um dos pilares da fé judaica, tanto em sua fase bíblica quanto rabínica ${ }^{98}$. A idéia de que o Deus de Israel estabeleceu uma Aliança com o povo judeu, diferenciando-o das demais nações do mundo, está presente em toda a história desta religião. Vejamos como esta idéia se desenvolveu até a Shoá.

A doutrina da Eleição de Israel é inaugurada já no Pentateuco ${ }^{99}$, o conjunto formado pelos primeiros cinco livros da Bíblia Hebraica, chamado Torá ${ }^{100} \mathrm{em}$ hebraico. Ali, a relação entre a divindade e o povo israelita ganhou seu contorno clássico, na forma de Aliança ou Pacto ${ }^{101}$ - em hebraico, brit (ברית).

No Pentateuco, a escolha divina não está ligada a nenhum mérito especial do povo israelita ${ }^{102}$. Como esclarece o autor do Deuteronômio, "não é pela tua (de Israel) justiça nem pela retidão de teu coração que herdarás a terra" (Dt 9:5) e "se o Senhor se ligou a vós e vos escolheu, não foi por serdes o mais numeroso dentre todos os povos, pois sois o menor de todos os povos ... é porque o Senhor vos ama e

\footnotetext{
${ }^{98}$ Tratei extensivamente da questão do povo eleito em meu livro A Eleição de Israel - Um Estudo Histórico-Comparativo da Doutrina do 'Povo Eleito' (Editora Humanitas, 2003). O presente capítulo é um sumário da pesquisa apresentada neste livro.

${ }^{99}$ Sobre este ponto, há opiniões divergentes. Julius Wellhausen (Wellhausen, 1958, pg. 417 / Hillers, 1969, pgs. 20 e 21), um dos grandes nomes da Crítica Bíblica, defendeu como um dos pontos-chave de sua obra que tanto a idéia de Aliança quanto a de monoteísmo foram conceitos tardios na história israelita e não contemporâneos a Abraão ou Moisés. Para ele, foi somente com os profetas que estas formulações apareceram no pensamento israelita e, a partir daí, teriam sido retrocedidas ficticiamente a tempos anteriores. A hipótese de Wellhausen foi criticada posteriorente (Hillers, 1969, pgs. 100 e 101 / Bright, 1977, pg. 26). Seus críticos afirmaram que a idéia de Aliança já estava presente muito antes do aparecimento dos profetas, se não no texto bíblico propriamente dito, pelo menos no pensamento israelita.

${ }^{100}$ Torá (תורה) - "ensino, doutrina, instrução, lei". No sentido mais restrito, é sinônimo de Pentateuco, os cinco primeiros livros da Bíblia, e núcleo do judaísmo. Em seu sentido mais amplo, nomeia toda a literatura e religião judaicas. Outra utilização do termo é para diferenciar a Bíblia Hebraica (Torá escrita) da tradição interpretativa dos rabinos (Torá oral).

${ }^{101}$ A palavra hebraica brit é traduzida neste capítulo como Aliança ou Pacto, usando notação proposta por McCarthy (1963, pg. 10)

${ }^{102}$ Loveley, 1967, pg. 242.
} 
mantém o juramento feito a vossos pais" (Dt 7:7 e 8). Ou seja, a Eleição de Israel é apresentada não como consequência de uma característica inata ou de um ato particular deste povo, mas como decisão livre e amorosa da divindade ${ }^{103}$.

É importante notar que na Torá coexistem duas concepções bem diferentes de Aliança com Israel. A primeira, o Pacto com Abraão, em Gn 15 e 17, o patriarca recebe uma promessa divina gratuita, que assegura posteridade numerosa e posse da terra de Canaã para sua descendência. É gratuita, pois esta Aliança não prevê a Abraão outros encargos além de ter fé e continuar sendo um homem de boa conduta. Não há lista de mandamentos, nem obrigações a serem observadas ${ }^{104}$.

Já a segunda concepção de Aliança do Pentateuco, o Pacto mediado por Moisés, é quase ${ }^{105}$ oposto ao anterior, ao estabelecer um contrato entre a divindade e todo o povo israelita onde a "gratuidade" desaparece e a observância de mandamentos é a condição para o recebimento das benesses da Aliança (Ex 19:5) ${ }^{106}$. Nada é incondicional no pacto mosaico e o não-cumprimento das estipulações vem acompanhado de ameaça de rompimento e outros castigos terríveis.

Os livros seguintes da Bíblia ${ }^{107}$ mencionam ainda uma outra Aliança, desta vez celebrada entre Deus e o rei Davi. Neste Pacto, a divindade garante a manutenção da dinastia real davídica pela eternidade e Sua presença na capital do reino, Jerusalém. Esta idéia é encontrada em diversos Salmos ${ }^{108}$, que supõem-se eram utilizados no culto do Templo de Jerusalém, o que levou os pesquisadores a concluirem que a crença na Aliança com Davi se tornou teologia oficial no reino de Judá ${ }^{109}$.

\footnotetext{
${ }^{103}$ Snaith, 1950, pgs. 135 e 136 / Bright, 2000, pg. 156.

${ }^{104}$ Bright, 1977, pgs. 25 e 26 / Hillers, 1969, pgs. 101, 103, 104, 105 / Hillers, 1987, pg. 134 / Eichrodt, 1975, pgs. 458 e 459 / Schildenberger, 1970 / Yonick, 1967, pg. 403.

${ }^{105}$ Diz-se que a Aliança estabelecida com Moisés é "quase" - e não inteiramente - oposta àquela firmada com Abraão porque também há semelhanças entre elas. Assim como a circuncisão foi o "sinal" da aliança abrâmica, o pacto mosaico tem o descanso semanal como "sinal" (Ex 31:16 e 17). Também, em ambas, a iniciativa parte da divindade, como um ato superior de Sua vontade e de Seu amor livremente concedido (Schildenberger, 1970 / Loveley, 1967, pg. 242 / Snaith, 1950, pgs. 135 e 136 / Bright, 2000, pg. 156).

${ }^{106}$ Bright, 1977, pgs. 28 e 44 / Friedman, 1989, pgs. 141 e 142 / McCarthy, 1972, pgs. 53 e 54 / Yonick, 1967, pg. 403.

${ }^{107}$ Bright, 1977, pg. 55. 58, 59, 60, 61, 62, 65, 67, 68 e 69.

${ }_{108}$ ver S1 48:2, S1 76:3, S1 78:68 a 70, S1 89:21, 24, 30 a 34, S1 132.

${ }^{109}$ Bright, 1977, pgs. 58, 59 e 60.
} 
Vimos acima que duas concepções distintas de Aliança conviviam no Pentateuco: a abrâmica - gratuita, eterna - e a mosaica - condicionada ao cumprimento dos mandamentos. Pois foi com base na primeira ${ }^{110}$ que se formulou a Aliança com a Casa de Davi. "Se (Davi) cometer alguma falta", diz o profeta Natã transmitindo a vontade de Deus, "eu o corrigirei servindo-me de homens como bastão (...) mas minha fidelidade não se afastará dele" (2Sm 7:14 e 15). As promessas de Deus para o monarca, como fora com o patriarca Abraão, eram incondicionais e mesmo delitos por parte do rei não poderiam anulá-las. Uma grande confiança no futuro marca a aliança davídica, pois se Deus mora na capital do reino, então o povo nada deveria temer.

Porém, a crença na Aliança com Davi apresentava problemas teológicos e morais. A firme confiança ${ }^{111}$ que provocava no povo poderia sempre passar de elogiável fé religiosa à perigosa auto-suficiência. As promessas seguras da divindade, reafirmadas no culto oficial, eclipsava as severas estipulações da tradição do Sinai, que sempre afirmou que, a fim de conseguir segurança e prosperidade, era necessária antes retidão moral. Foi justamente contra este excesso de confiança desvinculado de compromissos morais que se ergueram os profetas clássicos.

Pode-se afirmar ${ }^{112}$, de forma generalizada, que os profetas clássicos recuperaram a esquecida tradição da aliança mosaica e seu característico tom moraleducativo que, como vimos, não era a ideologia predominante na época da monarquia. Mas, por outro lado, os profetas não rejeitaram as esperanças da aliança davídica e até reforçaram-nas, apesar de denunciarem a ilusão de segurança que esta doutrina naturalmente difundia.

O Primeiro Isaías, que testemunhou a destruição do reino de Israel em 722 a.e.c. e o cerco contra Jerusalém pela Assíria, continuou ${ }^{113}$ a acreditar firmemente nas promessas a Davi e durante toda a sua pregação exortou a nação a confiar nelas. Previa um futuro em que "haverá paz sem fim para o trono de Davi e para a sua realeza" (Is 9:6). Porém, em seu discurso, ele também recuperou a tradição mosaica.

\footnotetext{
${ }^{110}$ Hillers, 1969, pg. 106, 110, 112 / Bright, 1977, pg. 70.

111 Bright, 1977, pg. 73 a 75.

112 Bright, 2000, pgs. 294 e 295/ Yonick, 1967, pg. 404.

113 Bright, 2000, pgs. 294 a 296.
} 
Se os assírios estavam ameaçando de morte o rei da linhagem de Davi e se estavam sitiando a cidade sagrada, isto se devia às transgressões dos mandamentos divinos. Para Isaías, "os habitantes transgrediram as leis, mudaram os preceitos, romperam a aliança perene; eis porque a maldição devora a terra" (Is 24:5 e 6). Portanto, no pensamento do profeta, a promessa da Aliança de Davi se amalgama com as condições do Pacto de Moisés.

De modo semelhante, Jeremias, que testemunhou a destruição de Jerusalém pelos babilônios em 587 a.e.c., explicou ${ }^{114}$ a tragédia retomando com vigor a tradição da aliança mosaica. Entendia como lógica a condenação de Judá, uma consequência direta do justo julgamento divino pela violação das prescrições da Aliança (Jr 32:17, 22, 23). Mas o profeta não negou a possibilidade de realização das promessas da tradição davídica. Projetou para o futuro o restabelecimento da dinastia de Davi e do Estado de Judá, estabilizados por monarcas que, ao contrário dos reis que conhecera, exerceriam o poder segundo os mandamentos divinos (Jr 23:5 e 6).

Também os profetas surgidos no exilio - Ezequiel e o Segundo Isaías - não destoaram de seus antecessores: interpretaram as desgraças nacionais baseados na quebra da aliança mosaica e insuflaram esperança em seus correligionários lembrando-os das promessas da aliança davídica ${ }^{115}$. A mesma mensagem está presente em Zacarias, um dos últimos profetas israelitas, que explicou de forma semelhante a situação do povo judeu à época do Retorno do Exílio ${ }^{116}$.

O amálgama fabricado pelos profetas entre as alianças abrâmica-davídica de um lado, e mosaica de outro, tornou-se a norma no judaísmo. Seguindo a mensagem

\footnotetext{
${ }^{114}$ Bright, 2000, pgs. 333 a 335.

${ }^{115}$ Ezequiel repreendia os judeus à maneira de Moisés, chamando-os de "povo rebelde" (Ez 2:5, 3:26), que descumpriram as prescrições divinas e que, por isso, foram castigados com a destruição de sua pátria (Ez 7: 1 e.d. e 33:23 e.d.). Por outro lado, falava de um futuro onde um príncipe da Casa de Davi voltaria a reinar sobre um Israel restaurado e seguro em seu território (Ez 34:23 e.d.). O mesmo se repete na obra do Segundo Isaías: o Deus de Israel entregou seu povo aos saqueadores como castigo (Is 42:24), mas voltaria um dia a habitar Jerusalém, como um marido que retorna à sua esposa (Is 54:1 e.d.).

${ }^{116}$ Zacarias explicou a difícil situação vivida pelos judeus como um resultado da transgressão das leis mosaicas (Zc 7:11 e.d.). Mas ele também acreditava que as glórias do passado seriam revividas e que o Deus de Israel voltaria a habitar entre seu povo (Zc 2:14). Jerusalém, "mesmo que pareça impossível aos olhos do que resta do povo", seria reerguida num grandioso futuro quando todas as nações acorreriam à cidade para venerar o Deus de Israel, e aquela nação que assim não o fizesse, suas terras não receberiam chuvas (Zc 8:6 e 14:16 e.d.).
} 
profética, a religião judaica passou a prescrever o cumprimento de leis baseadas nos mandamentos do Sinai (pacto mosaico), ao mesmo tempo em que aguarda um tempo messiânico e de prosperidade que será inagurado por um descendente de Davi (pacto abrâmico-davídico).

Mas os profetas trouxeram ainda uma outra inovação à religião judaica, que impactou profundamente a concepção de "povo eleito". Até a aparição dos profetas, a idéia de que o Deus de Israel seria algum dia aceito por não-israelitas é desconhecida $^{117}$. O anterior Pentateuco eximia os demais povos do pecado de idolatria, pois entendia que a divindade não se revelara aos povos não-hebraicos. Já os profetas modificaram radicalmente esta visão ao universalizarem a fé bíblica ${ }^{118}$. $\mathrm{O}$ tão ansiado futuro, que no pensamento pré-profético traria exclusivamente a redenção de Israel, transformou-se agora na expectativa de que um dia todos os povos abandonariam seus "falsos deuses" e compartilhariam a "divina misericórdia" do Deus bíblico.

Consequentemente, a partir dos profetas, passaram a existir no judaísmo duas escolas distintas ${ }^{119}$, com implicações também na concepção da Eleição de Israel. A primeira, baseada na religião israelita mais antiga, adota uma mensagem mais nacionalista e particularista. A segunda, inspirada na mensagem profética, propõe uma fé mais abrangente e universal. Vejamos como isto influenciou na questão do "povo eleito".

O Talmud ${ }^{120}$, obra paradigmática do judaísmo pós-bíblico, considerou a doutrina da Eleição de Israel como um dogma ${ }^{121}$ e não aceitá-la, como heresia ${ }^{122}$. Repetidas vezes é reafirmada no Talmud - e até com mais vigor do que na Bíblia Hebraica - a íntima relação existente entre o povo judeu e seu Deus. Mesmo com a

\footnotetext{
${ }^{117}$ Kaufmann, 1963, pgs. 127 e.d.

${ }^{118}$ Kaufmann, 1963, pgs. 346 e.d./ Bright, 2000, pgs. 357, 442, 443

${ }^{119}$ Bright, 2000, pg. 443 / Simon, 1996, pg. 63.

${ }^{120}$ Talmud (תלמוד) - do verbo hebraico "estudar". Em aramaico (língua predominante no Talmud), Guemara. Obra-prima do judaísmo rabínico. Baseados na Mishnah, os rabinos das gerações seguintes expandiram-na e transcenderam-na, em discussões e reflexões realizadas em yeshivot na Terra de Israel e na Babilônia. Por volta do ano 400, este material foi editado no Talmud de Jerusalém, uma obra na realidade realizada na Galiléia. Duzentos anos mais tarde, na região do atual Iraque, foi editado o Talmud da Babilônia, que se tornou a maior autoridade literária religiosa do judaísmo pós-bíblico.

${ }^{121}$ Cohen, 1995, pg. 59.

${ }^{122}$ Sanh. 99a citado em Silver, 1971, pg. 359.
} 
destruição de Jerusalém no ano 70, a subsequente diáspora e a degradação política dos judeus, aos olhos dos rabinos talmúdicos o povo não deixou de ser a mesma nação de Israel bíblica, eleita e amada por seu Deus ${ }^{123}$.

Os rabinos talmúdicos, seguindo os autores bíblicos, não pensavam que os judeus tinham alguma superioridade inata em relação aos outros povos. A eleição ${ }^{124}$, diziam, somente aconteceu porque Israel aceitou os mandamentos divinos e este status especial cessaria imediatamente se abandonassem sua observância. Os mandamentos não eram posse exclusiva dos judeus e sim, destinados à toda humanidade. "O gentio que obedece a Torá é igual ao sumo-sacerdote" ${ }^{125}$. É verdade que existiram vozes discordantes: "O gentio que se ocupa com o estudo da Torá merece a morte" ${ }^{126}$ ou "convertidos são tão incômodos a Israel como uma chaga" ${ }^{127}$. Mas estas não eram as opiniões majoritárias ${ }^{128}$. Na realidade, o que se nota no Talmud é a presença da mesma divisão entre particularistas e universalistas que, como vimos, originou-se ainda na Bíblia Hebraica.

Esta mesma divisão entre particularistas e universalistas repetiu-se no judaísmo medieval, corporificada na obra de dois importantes autores. O primeiro é Yehuda Halevi (1075-1141), poeta e filósofo que viveu na Espanha sob domínio muçulmano. Em sua obra mais célebre, O Livro do Kuzari, Halevi radicalizou ${ }^{129}$ a doutrina da eleição, enfatizando seu aspecto mais particularista. Ao contrário das visões bíblica e talmúdica, afirmou que o povo judeu detinha sim uma característica inata que o levou a ser escolhido por Deus. Esta era a profecia, uma capacidade de ligação entre o humano e o divino, que Halevi acreditava ser restrita a Israel. Para ele, o povo judeu tinha uma posição central na História, era o "coração da humanidade". Tanto o cristianismo quanto o islamismo cumpriam uma função histórica em seu tempo, mas no final seriam convertidos à verdade do judaísmo.

\footnotetext{
${ }^{123}$ Urbach, 1971, pg. 654.

${ }^{124}$ Cohen, 1995, pgs. 62 e 63.

${ }^{125}$ Sifra XVIII 5 citado por Cohen, 1995, pg. 63.

${ }^{126}$ Sanh. 59a in Cohen, 1995, pg. 63.

127 Jeb. 47b in Cohen, 1995, pg. 64.

${ }^{128}$ Cohen, 1995, pg. 63 / Schechter, 1961, pg. 62.

${ }^{129}$ Novak, 1995, pgs. 215 e.d. / Slonimsky, 1974, pgs. 179 e.d.
} 
Contemporâneo de Halevi e considerada a maior personalidade judaica do período pós-bíblico, Moshe ben Maimon, conhecido como Maimônides (1135-1204), adotou uma posição diametralmente oposta quanto à Eleição de Israel. O racionalismo de fundo grego ${ }^{130}$ que permeava suas idéias impedia-o de conceber uma verdade que fosse apreendida apenas por um povo especial. Uma verdade deveria ser universal e válida para todos os homens. Daí que a doutrina do "povo eleito" quase não é abordada por Maimônides e, significativamente, ele não a incluiu entre os 13 princípios básicos da fé judaica que elaborou. Ao contrário de Halevi, Maimônides não confinou o dom da profecia em Israel e defendeu-a como uma possibilidade da natureza humana em geral ${ }^{131}$.

Na Era Moderna, os rabinos continuaram afirmando a Eleição de Israel, tanto em sua versão particularista quanto universalista. O rabino neo-ortodoxo Samson Raphael Hirsch afirmou que os judeus foram eleitos para que ensinassem o monoteísmo aos demais povos, por isso "o mais querido ideal de Israel é a fraternidade universal da humanidade" ${ }^{132}$. Hirsch explicou, através da ídéia de eleição, a existência segregada dos judeus: assim como o patriarca Abraão havia sido separado por Deus, mas continuou sendo um homem de bem, também o judaísmo deveria se isolar "no interesse da humanidade". Mas seria justamente este povo isolado por Deus que traria os pensamentos e sentimentos mais universais, para benefício de todos.

Abraham Isaac Kook (1865-1935), rabino-chefe da comunidade judaica palestina pré-Estado de Israel, reafirmou com ênfase a eleição ${ }^{133}$, justamente nos anos de crise que antecederam o nazismo. Para ele, os judeus foram ordenados a viver separados das outras nações para que pudessem "disseminar o conhecimento de Deus e limpar o mundo inteiro de toda impureza e escuridão”. Sionista, Kook pensava que o restabelecimento político dos judeus transformaria todas as nações da Terra e impediria a catástrofe generalizada que se vislumbrava naqueles anos. Reafirmando com entusiasmo a doutrina da eleição, escreveu que "nossa revivificação (política) fará toda vida ficar luminosa, todas as discórdias serão resolvidas, todas as religiões

\footnotetext{
${ }^{130}$ Jacobs, 1971, pg. 392.

${ }^{131}$ Novak, 1995, pg. 229.

${ }^{132}$ Hertzberg, 1968, pg. 25.

${ }^{133}$ Hertzberg, 1971, pgs. 422 a 424.
} 
vestirão nova e preciosa roupa, lançando fora tudo o que for sujo, abominável e impuro".

Mesmo o movimento de Reforma do judaísmo, surgido no início do século XIX, não descartou a doutrina da Eleição de Israel. A Plataforma de Pittsburgh, declaração de princípios do movimento reformista norte-americano de 1895, afirmava $^{134}$ que a diáspora dos judeus não deveria ser encarada como uma punição divina ao pecados de Israel, mas como reafirmação do papel missionário dos judeus, espalhados agora pelo mundo com o encargo de "cumprir sua elevada tarefa sacerdotal de conduzir as nações ao verdadeiro conhecimento e adoração a Deus". Desta maneira, o documento reafirmava a doutrina da Eleição de Israel, declarando mesmo que esta deveria ser enfatizada "tão vigorosamente como fora no passado". Mas, por outro lado, ressalvava que a mesma ênfase deveria ser feita no amor comum de Deus a toda a humanidade.

A Plataforma de Pittsburgh é um exemplo paradigmático da concepção que passaram a ter boa parte dos pensadores judeus da era moderna, principalmente os reformistas, mas mesmo alguns ortodoxos. Substituíram a noção de "povo eleito" pela idéia de "missão dos judeus" ${ }^{135}$. A idéia não era nova; na realidade presencia-se a antiga dicotomia particularismo versus universalismo, exibida no judaísmo desde os tempos bíblicos. Na época moderna, testemunhou-se a emergência de uma tendência mais universalista no judaísmo, sobrepujando visões mais nacionalistas - isto até o Holocausto.

\footnotetext{
${ }^{134}$ Plaut, 1965, pgs. 31 a 34.

${ }^{135}$ Silberman, 1971, pg. 501 / Levy, 1993, pgs. 91 e 99.
} 


\section{2 - HISTÓRIA COMO REVELAÇÃO DIVINA (השגחה אלהית)}

Como o Holocausto pode ser entendido na história sagrada de Israel?

A questão se resume, como apontou o historiador das religiões Mircea Eliade $^{136}$, em verificar como cada cultura fornece a seus membros uma explicação para catástrofes, infelicidades e acontecimentos aparentemente arbitrários que assolam o mundo. Para evitar que um sentimento de "terror da história" ${ }^{137}$ leve indivíduos ao desespero, pensadores e teólogos esforçam-se para fornecer significados a estes perturbadores eventos.

Como apontou Eliade ${ }^{138}$, nas sociedades ditas "primitivas", anteriores ao período bíblico, o "terror da história" era superado através da idéia de Eterno Retorno. O passar do tempo era concebido de forma circular, onde o futuro sempre repetiria o passado, que fora uma época idealizada e arquetípica. Assim, o tempo histórico era abolido e criava-se uma concepção otimista de História, onde mesmo a morte era vista como necessária para a regeneração do mundo. Quando alguma infelicidade traumática afetava o indivíduo ou o grupo, isto era explicado como magia vinda do inimigo, que deveria ser combatida pelo sacerdote ou feiticeiro.

A Biblia Hebraica descartou ${ }^{139}$ esta noção circular de tempo e considerou a História como uma sucessão linear de acontecimentos - com início, meio e fim. A História, na concepção bíblica, é formada por eventos únicos e irreversíveis, podendose distinguir o passado do presente e o presente do futuro. $\mathrm{Na} \mathrm{BH}$, também não há

\footnotetext{
${ }^{136}$ Eliade, 1954, pgs. 95, 96, 149 e 162.

${ }^{137}$ Eliade, 1954, pgs. 150 e 159.

${ }^{138}$ Eliade, 1954, pgs. ix, 36, 74, 75, 85, 86, 88, 95 e 96.

${ }^{139}$ Apesar da visão da Bíblia Hebraica caracterizar-se pela visão linear de História, também encontra-se ali elementos de circularidade. Por exemplo, o futuro messiânico, vislumbrado pelos profetas clássicos, marca a restauração de uma pureza e integridade do passado. Neste futuro, os milagres do Êxodo retornariam (Miquéias 7:15), as promessas a Davi seriam reconfirmadas (Is 55:3), uma nova aliança seria celebrada ( $\mathrm{Jr}$ 31:31) e a rígida disciplina divina do deserto voltaria (Ez 20:33 a 36). A circularidade também pode ser encontrada no culto bíblico, com as mesmas festividades sendo observadas todos os anos. Igualmente é possível ditinguir circularidade na historiografia da Escola Deuteronomista - responsável pela redação dos livros Josué, Juízes, 1 e 2 Samuel, 1 e 2 Reis -, onde o ciclo pecado-punição-arrependimento-expiação é visto como o motor da História. Outro exemplo de circularidade no judaísmo é a leitura completa do Pentateuco nas sinagogas, realizada todos os anos (Steensgaard, 1993, pgs. 82 e 83 / Eliade, 1954, pg. 87, 106, 107, 111 / Steensgaard, 1993, pgs. 64, 68 e 65 / Seltzer, 1987, pg. 391 / Yerushalmi, 1982, pg. 42).
} 
lugar para o "terror da história", pois os acontecimentos são vistos como dotados de propósito e coerência ${ }^{140}$.

Os autores da Biblia Hebraica ${ }^{141}$ não antipatizavam menos com a História do que os pensadores "primitivos". Ambos guardavam a mesma atitude anti-histórica. A diferença é que, no pensamento israelita, a História não é ignorada ou abolida, mas sim tolerada, com a esperança de que um dia, no futuro messiânico, finalmente acabaria (ou seria transformada).

A Bíblia Hebraica ${ }^{142}$ não apenas reconheceu a existência da História, como também a sacralizou. O desenrolar dos acontecimentos era visto como uma contínua ilustração da verdade religiosa. Os historiadores bíblicos pretendiam mostrar, a partir do relato do passado, que Deus continuava fiel à Aliança, e que sempre punia o perverso e recompensava o justo. Em outras palavras, a BH transformou a História em epifania (aparição ou manifestação da divindade).

A própria apreensão ${ }^{143}$ da natureza de Deus é elaborada na Bíblia Hebraica a partir da História. A divindade apresenta-se no primeiro dos Dez Mandamentos como “Eu sou Jeová, seu Deus, que te tirei da terra do Egito, da casa da servidão" (Ex 20:2). $\mathrm{Na} \mathrm{BH}$, o Deus de Israel controla toda a História, inclusive dos povos não-israelitas. Como afirmou o profeta Amós: "Não sois vós para Comigo, ó filhos de Israel, como os filhos dos etíopes? (...) Não fiz Eu subir a Israel da terra do Egito, e aos filisteus de Caftor, e aos sírios de Quir?” (Am 9:7). O texto bíblico afirma ainda que a divindade intervém incessantemente na História, a fim de operar moral, justiça e amor.

Mas esta divindade ${ }^{144}$, que controlava toda a História, tinha seu principal interesse voltado para o destino do pequeno Israel. O centro da narrativa da BH é uma história épica que descreve o surgimento deste povo específico e seu contínuo relacionamento com a divindade. Por causa de sua relação especial com Deus, o povo

\footnotetext{
${ }^{140}$ Steensgaard, 1993, pgs. 75 e 76 / Neusner, 2000, pg. 18 / Yerushalmi, 1982, pg. 10.

${ }^{141}$ Eliade, 1954, pg. 87, 106, 107, 111, 112.

${ }^{142}$ Meyer, 1974, pgs. 7 e 8 / Eliade, 1954,pg. 104 / Yerushalmi, 1982, pgs. 8 e 9.

${ }^{143}$ Cohon, 1971, pg. 124 e 125/ Eliade, 1954, pg. 103, 104 /Steensgaard, 1993, pgs. 75 e 76 / Meyer, 1974, pgs. 6 e 7 / Yerushalmi, 1982,pg. 9.

${ }^{144}$ Seltzer, 1987, pg. 390 / Finkelstein, 2001, pg. 8 / Cohon, 1971, pgs. 124 e 125 / Meyer, 1974, pg. 7.
} 
eleito encontrava-se no centro da História. As demais nações existiam principalmente como instrumento para a divindade exercer sua vontade sobre Israel ${ }^{145}$.

No final da era bíblica ${ }^{146}$, o judaísmo sofreu uma reviravolta política que transformou sua apreensão da História. Com a perda da independência nacional após a destruição de Jerusalém no ano 70, o povo judeu deixou de ser um sujeito político ativo, transformando-se numa nação dispersa, sem centro de poder ou de culto. Os pesquisadores ainda divergem sobre o principal catalisador desta transformação de mentalidade - se foi apenas a perda de independência ou o excesso de perseguições ou a falta de uma classe de escribas -, mas o fato é que os judeus, no alvorecer da era rabínica, deixaram de lado a historiografia, numa atitude que continuou pelos 15 séculos seguintes ${ }^{147}$.

Contrastando com a Bíblia Hebraica, a Mishnah, a primeira grande produção literária da era rabínica, quase não aborda a História. Não há nenhum tipo de narrativa prolongada, nenhuma grande concepção sobre eventos históricos e mesmo referências a acontecimentos da época são raras. Não há capítulos dedicados aos grandes fatos contemporâneos - destruição do Templo e a Revolta de Bar Kokhba -, nem mesmo muita informação sobre a vida dos grandes rabinos. Todo o interesse da Mishnah está voltado para as leis religiosas. Quando eventos históricos são mencionados, não é para narrá-los ou extrair lições, mas apenas para ilustrar algum aspecto da lei ${ }^{148}$.

\footnotetext{
${ }^{145}$ Sendo basicamente religiosa, a historiografia bíblica não estava interessada nos eventos históricos por si mesmos. Nisto se diferenciava da historiografia praticada por povos contemporâneos dos israelitas antigos, especialmente assírios, babilônios e egípcios. As cortes reais destas nações produziram relatos detalhados de campanhas militares, listas de reis e anais. Ao que tudo indica, este tipo de crônica oficial também existiu no Israel antigo - a BH menciona fontes como "Atos de Salomão", "Crônica dos Reis de Israel" e "Crônica dos Reis de Judá" -, mas estes textos não foram preservados no cânone bíblico (Meyer, 1974, pgs. 6 e 7 / Thompson, 1992, pgs. 206 e 207).

A BH também se diferenciava da historiografia surgida posteriormente na Grécia antiga. Os autores gregos viam sua tarefa como historía ("pesquisa") e almejavam chegar a uma versão correta e verdadeira sobre o passado. Esta postura racional, crítica e científica, que buscava se afastar de uma tradição épica e mitológica, não é encontrada na Bíblia Hebraica (Thompson, 1992, pg. 206).

${ }^{146} \mathrm{Na}$ fase final da Era Bíblica, o pensamento israelita passou a ser fortemente influenciado por tendências apocalípticas. Da mesma maneira que os profetas clássicos que os antecederam, os autores apocalípticos também acreditavam na consumação da História num futuro onde a vida seria transformada radicalmente. Mas diferentemente dos profetas, que anteviam estas modificações dentro do processo histórico, os apocalípticos falavam no Fim da História. Para estes, tudo já havia sido prédeterminado e planejado por Deus desde o início da História. Aos seres humanos, caberia apenas optar por seguir o bem ou o mal, e arcar com a responsabilidade no julgamento final, que estaria prestes a ocorrer (Steensgaard, 1993, pgs. 96, 98, 99 e 100 / Meyer, 1974, pgs. 3, 12 e 13).

${ }^{147}$ Yerushalmi, 1982, pgs. 16 e 52 // Meyer, 1974, pg. 13.

${ }^{148}$ Neusner, 2000, pgs. 1, 2, 3 e 8.
} 
O Talmud (tanto o da Babilônia quanto o de Jerusalém) mostra um certo retorno de interesse pela História, através de agadot envolvendo rabinos e acontecimentos políticos da época. Mas não se observa no corpus talmúdico a mesma ênfase na interpretação de acontecimentos históricos, como existira na Bíblia Hebraica ${ }^{149}$.

Os rabinos tinham certeza sobre o passado bíblico e a redenção futura. Já o intervalo tempestuoso entre estas duas eras deveria ser atravessado com paciência e confiança em Deus ${ }^{150}$. A obrigação dos judeus era se preparar para a chegada do messias, esforçando-se para ser um "povo santo", observando a halakhah e dedicando-se ao estudo dos textos sagrados. Mesmo sem se dedicar à historiografia, os rabinos continuaram acreditando numa divindade controladora de todos os eventos, no povo judeu como personagem central do drama humano e na Bíblia Hebraica como ferramenta primordial para o entendimento dos acontecimentos ${ }^{151}$.

Este padrão continuou na Idade Média, com uma dedicação judaica praticamente nula à historiografia durante todo o período. Quando queriam interpretar acontecimentos contemporâneos, os pensadores judeus medievais recorriam aos antigos padrões da Bíblia Hebraica. Assim, um novo opressor era chamado de "Haman" e o eventual judeu da Corte que tentava salvar a comunidade era "Mordechai". O cristianismo era "Edom" ou "Esaú" e o islamismo, "Ishmael". Novas nações eram relacionadas a antigos nomes da BH, como Espanha e "Sefarad" ou Alemanha e “Ashkenaz”. Também os grandes conflitos da época - Pérsia e Bizâncio,

\footnotetext{
${ }^{149}$ A própria história do período talmúdico não pode ser escrita com segurança baseada nesta vasta literatura, devido à falta de rigor nos registros ( Neusner, 2000, pgs. 8, 9 e 13 / Yerushalmi, 1982, pg. 18).

${ }^{150}$ Os rabinos da era talmúdica condenaram a prática de buscar em eventos contemporâneos os sinais de uma iminente redenção, calejados que estavam com as lições dos fracassados levantes judaicos contra Roma nos séculos I e II, todos eles motivados por delírios messiânicos. Não que os rabinos tivessem repudiado a fé na era messiânica, muito pelo contrário. Mas para resguardar a comunidade de novas aventuras catastróficas, decretaram que o tempo da redenção deveria ser deixado exclusivamente a cargo de Deus. Com isto, interpretações messiânicas da História passaram a ser uma atividade marginal no judaísmo rabínico - embora um fenômeno sempre persistente - e aprofundou-se a desatenção pelos eventos contemporâneos (Yerushalmi, 1982, pgs. 24 e 25).

${ }^{151}$ Yerushalmi, 1982, pgs. 21, 22, 24 e 26.
} 
as conquistas árabes, a invasão mongol e, posteriormente, as guerras napoleônicas eram invariavelmente interpretadas como a apocalíptica "guerra de Gog e Magog"152.

Os judeus ashkenazim ${ }^{153}$ medievais tiveram um breve momento de consciência histórica despertada pelo massacre da Primeira Cruzada (1096), quando produziram crônicas para imortalizar o evento. Mas este pique de interesse pela História foi efêmero e excepcional, e, até onde sabemos, o judaísmo ashkenazi manifestou pouco interesse nos séculos seguintes até mesmo em narrar sua própria história ${ }^{154}$. Também os judeus sefaradim ${ }^{155}$ da Espanha medieval não foram mais interessados em historiografia. Maimônides guardava até mesmo uma atitude desdenhosa em relação ao estudo da História, classificando-o como "perda de tempo" $" 156$.

Este fato ${ }^{157}$ chama a atenção, dado que os sefaradim, sob influência da cultura muçulmana sob a qual viviam, dedicaram-se a campos racionalistas do conhecimento até então quase inexplorados no âmbito judaico, como gramática, ciências ou filosofia. Mas quanto à historiografia, uma área especialmente cultivada pelos muçulmanos, preferiram seguir a tradição dos rabinos clássicos e quase não a exerceram.

Dentro deste quadro de rechaço à historiografia, o século XVI representou uma exceção. Neste período, ocorreu um súbito interesse dos judeus pela História, estimulados pela Expulsão da Espanha (1492), que levou-os a relatar os chocantes acontecimentos e compará-los com outras perseguições do passado. Um outro fator de

\footnotetext{
${ }^{152}$ Yerushalmi, 1982, pgs. 31, 36 e 37.

${ }^{153}$ Ashkenaz (אשכנז) - Em seu sentido mais restrito, denota a Alemanha e sua comunidade judaica (askenazi, pl. ashkenazim). Mais amplamente, identifica o legado cultural e religioso, a partir da Idade Média, dos judeus habitantes da França, Alemanha e, posteriormente, Europa Oriental e outras comunidades ao redor do globo. O termo é usado em contraste com Sefarad.

${ }^{154}$ Meyer, 1974, pg. 17 / Yerushalmi, 1982, pgs 36 e 37.

${ }^{155}$ Sefarad (ספרד) - Civilização judaica que floresceu na Espanha e Portugal medievais. Quando a região foi conquistada pelos árabes no ano 711, os sefaradim (sing. sefaradi) influenciaram-se pelo judaísmo babilônico e pela cultura muçulmana. A Expulsão da Espanha, em 1492, pelos novos soberanos cristãos, colocou um ponto final nesta cultura local, que continuou florescendo em sua diáspora. O termo é usado em contraste com Ashkenaz.

${ }^{156}$ Meyer, 1974, pg. 14 / Seltzer, 1987, pg. 393.

${ }^{157}$ Yerushalmi, 1982, pg. 33.
} 
estímulo foi a Renascença européia, que redescobriu a tradição historiográfica grecoromana e influenciou também autores judeus, ainda que marginalmente ${ }^{158}$.

Ao longo deste século XVI, escritores judeus elaboraram pelo menos dez tratados historiográficos de fôlego, incluindo um deles em língua portuguesa, “Consolação às Tribulações de Israel”, de Samuel Usque. Mas estas obras tiveram um alcance limitado na mentalidade judaica. Não alcançaram o mesmo nível de qualidade de trabalhos contemporâneos feitos por não-judeus, continuaram sendo marcadamente teológicos, representaram uma fração bem pequena da literatura judaica produzida no mesmo período e, mais importante, não tiveram continuidade nos 200 anos seguintes $^{159}$.

Foi somente a partir do início do século XIX que surgiu uma historiografia moderna sobre os judeus e feita por judeus, destacando-se autores pioneiros como Heinrich Graetz, Simeon Dubnow, Salo Baron e Gershom Scholem. Mas aqui já não se pode falar numa historiografia religiosa. Estes historiadores, bem como seus seguidores acadêmicos da atualidade, recusam os dois parâmetros básicos da apreensão judaica tradicional de História: a crença na Providência divina como motor dos acontecimentos e a singularidade da trajetória dos judeus ${ }^{160}$.

\footnotetext{
${ }^{158}$ Seltzer, 1987, pg. 393 / Meyer, 1974, pgs. 17, 18 e 19 / Yerushalmi, 1982, pgs. 58 e 59.

${ }^{159}$ Yerushalmi, 1982, pgs. 57, 63 a 66, 73.

${ }^{160}$ Yerushalmi, 1982, pgs. 64, 65, 81, 87 e 89.
} 


\section{3- JÓ (איוב)}

\section{Como a mensagem do livro bíblico pode ser aplicada ao Holocausto?}

Não por coincidência, o Livro de Jó tem sido um instrumental utilizado amplamente pelos teólogos do Holocausto ${ }^{161}$. Quando a questão é o sofrimento do inocente e a teodicéia ${ }^{162}$, poucas obras da civilização judaico-cristã disputam em nível de elaboração com este livro bíblico ${ }^{163}$. Maestralmente mesclando fina teologia e soberba poesia, o autor de Jó produziu uma obra-prima ${ }^{164}$ que encantou e perturbou gerações de leitores - religiosos ou não ${ }^{165}$.

O Livro de Jó é uma obra complexa que, como veremos abaixo, gerou uma grande diversidade de interpretações teológicas. Para apresentar esta obra no presente capítulo, dividi a exposição em três partes: o enredo do livro; a multiplicidade de interpretações; Jó na tradição judaica.

\section{$\underline{1-\text { Enredo }}$}

O livro ${ }^{166}$ conta a história de Jó, habitante da terra de Uz e considerado pelo próprio Deus como o mais destacado indivíduo de seu tempo em termos de integridade, retidão e religiosidade. No início da narrativa, Jó é descrito como um homem rico, que vive feliz cercado de sua família e exerce até mesmo funções sacerdotais.

\footnotetext{
${ }^{161}$ Kepnes, 2000, pg. 253.

${ }^{162}$ Teodicéia - das palavras gregas theos (“deus”) e dike (“justiça”). Justificação de Deus. O esforço de pensadores religiosos em reconciliar as idéias de bondade e justiça divinas com os fatos observáveis de maldade e sofrimento no mundo.

${ }_{163}$ Kepnes, 2000, pg. 253 / Hartley, 1988, pg. 47 / Pope, 1974, pg. lxxiii / Leaman, 1995, pg. 3.

164 "Um dos personagens mais memoráveis da Bíblia" (Newsom, 1996, pg. 319); "uma obra-prima literária" (Habel, 1985, pg. 21); "a criativa combinação de idéias teológicas com técnica literária (...) uma brilhante tapeçaria de arte literária e disputa teológica" (Habel, 1985, pgs. 23 e 60); "[o] capítulo 3 de Jó [é] um dos mais soberbos não só da Bíblia, mas de toda a literatura mundial" (Dhorme, 1967, pgs. xxxvi); “o primeiro discurso de Deus em Jó [é] um trabalho de gênio inigualável na literatura mundial" (Pope, 1974, pg. xxviii); "um poeta genial (...) sua obra é aclamada como um das maiores obras-primas da literatura mundial" (Pope, 1974, pg. xli).

${ }^{165} \mathrm{O}$ Livro de Jó inspirou obras, entre outros, dos pintores Rubens, Rembrandt, William Blake e Oskar Kokoschka; dos escritores John Milton, Fyodor Dostoyevsky, Franz Kafka e Robert Frost; do compositor G.F. Handel e do psicólogo Carl Jung

(Hartley, 1988, pg. 11 / Encyclopaedia Judaica, 1 a edição, “Job”, Vol. 10, 1971).

${ }_{166}$ Dhorme, 1967, pgs. xiii, xiv, lxxvii, lxxviii, cxliii e cxxviii / Habel, 1985, pgs. 62 a 65 / Leaman, 1995, pgs. 10, 11, 19, 20, 21, 22, 24 e 223 / Glatzer, 1969, pgs. 7 e 8 / Friedman, 1971, pgs. 121 e 122.
} 
Mas como resultado de uma disputa celestial sobre as razões do comportamento íntegro de Jó, Deus concede a Satã permissão para testar sua virtude. Assim, precipitam-se sobre Jó uma desgraça após a outra, primeiro destruindo suas propriedades, depois sua família e finalmente seu próprio corpo.

Jó encontra-se desolado e arranhando os tumores de sua pele quando surgem outros três protagonistas do drama - seus amigos Elifaz, Bildad e Tzofar. Até este ponto (Cap 1 e 2), os eventos são narrados em prosa. Quando Jó inicia o diálogo com seus amigos, a linguagem torna-se poética, na forma de paralelismo bíblico. Segue-se então três ciclos de discursos poéticos (Caps 3 a 31), com cada amigo se expressando três vezes e, cada vez, provocando uma resposta de Jó ${ }^{167}$.

Os amigos são crentes absolutos na existência de Deus e porta-vozes da Doutrina de Retribuição, a idéia clássica da Bíblia Hebraica resumida na máxima “os perversos são sempre castigados e os justos, recompensados". Como seguidores fiéis desta doutrina, os amigos insistem que Jó deve ter pecado em algum momento do passado para estar vivendo no presente sua infeliz situação, pois não poderia haver castigo divino sem uma transgressão humana. A possibilidade de que Jó seja inocente - o que o leitor, mas não os protagonistas, sabe desde o início - nunca é seriamente considerada pelos amigos, que insistem que ele se arrependa humildemente frente a Deus.

Sem também nunca duvidar da existência de Deus, Jó refuta a Doutrina de Retribuição, considerando-a uma idéia simplória frente à complexidade do mundo. A realidade, afirma Jó, mostra que os justos sofrem neste mundo, enquanto os perversos prosperam. Daí, em seus discursos, ele não se dirigir à divindade em penitência, mas em indignação. A defesa de sua integridade é o que lhe resta em vida e, ao invés de negá-la como querem os amigos, ele está pronto a desafiar o próprio Deus. Jó intima a divindade para um litígio judicial, onde ambos apareceriam frente a uma corte imparcial e os argumentos de cada um seriam ouvidos, sem intimidações. Ele está convencido de que, nestas circunstâncias, seria totalmente inocentado.

\footnotetext{
${ }^{167}$ na forma presente do texto bíblico, o terceiro ciclo está incompleto.
} 
Quando os três amigos encerram suas falas, surge um novo personagem em cena, Elihu. Em sua argumentação em forma de poesia (Caps 32 a 37), ele balança entre apoiar a Doutrina de Retribuição dos amigos e sugerir que a terrível situação vivida por Jó é um teste-de-fé. Mas como Elihu insiste que Jó deva arrepender-se, sem o leitor saber exatamente do quê, o impasse continua.

Finalmente, o próprio Deus entra em cena, discursando em forma poética no meio de um redemoinho (Caps 38 a 42:6). Todos os demais personagens se silenciam e apenas Jó murmura algumas palavras. Deus ignora as questões levantadas por Jó, preferindo focalizar o discurso na ignorância humana frente à maravilha do Cosmo, indicando a presunção do ser humano em questionar a justiça divina. Como consequência da teofania, a hostilidade de Jó desaparece, substituída por calma e resignação.

No epílogo (Cap 42:7 a 17), novamente em forma de prosa, a divindade condena os três amigos por não terem dito "o que era correto, como o Meu servo Jó". Mas acaba perdoando-os, após Jó ter intercedido por eles através de orações e sacrifícios de animais. Jó tem suas prosperidades restituídas, em quantidade dobrada. A história termina com sua morte, feliz e rodeado por uma nova e numerosa família, "idoso e farto de dias".

\section{$\underline{2-\text { A multiplicidade de interpretações }}$}

O Livro de Jó é uma obra multi-facetada, que suscitou através dos séculos o aparecimento de uma grande variedade de interpretações e opiniões sobre qual seria a mensagem original que seu autor teria pensado em transmitir aos leitores ${ }^{168}$. O livro pode ser lido das mais diferentes maneiras: um protesto contra a justiça divina ${ }^{169}$, um exame do comportamento humano face ao sofrimento ${ }^{170}$, uma reflexão sobre a

\footnotetext{
${ }^{168}$ Friedman, 1971,pg. 121 / Leaman, 1995, pg. 27.

${ }^{169}$ Glatzer, 1969, pgs. 4 e 5.

${ }^{170}$ Newsom, 1996, pgs. 334 e 335 / Hartley, 1988, pg. 48.
} 
qualidade do governo de Deus no mundo ${ }^{171}$, um questionamento da visão simplista da Doutrina de Retribuição ${ }^{172}$ ou um ensaio sobre os limites do conhecimento humano ${ }^{173}$.

O personagem Jó também foi interpretado ${ }^{174}$ de diferentes formas: o sofredor inocente, o homem que confronta a indiferença e o mal no mundo, o desafiador solitário da justiça de Deus, o indivíduo que vive uma odisséia de fé, o personificador do mistério do sofrimento humano, o símbolo da futilidade em se perguntar sobre as questões fundamentais da existência ou o alvo do poder ilimitado de Deus.

O próprio sofrimento pode ser entendido ${ }^{175}$ de diversas maneiras ao longo do livro: como punição por pecados, o inevitável destino de frágeis mortais propensos ao mal, um ato de disciplina calculado de Deus, parte de um misterioso plano divino ou um teste-de-fé imposto ao justo.

Esta riqueza de interpretações é resultado da própria composição literária do livro ${ }^{176}$. Os comentaristas modernos identificam duas tradições bem distintas, que teriam sido amalgamadas pelo autor, mas não totalmente harmonizadas ${ }^{177}$. $\mathrm{Na}$ introdução e no epílogo (Caps 1,2 e 42), escritos em prosa, Jó é retratado como um homem piedoso e paciente, que aceita suas infelicidades com resignação e recusa-se a acusar Deus de injustiça. Já no restante do livro, em linguagem poética, Jó é um personagem rebelde e beligerante, até mesmo um blasfemador, cujas queixas amargas contra Deus chocam seus amigos.

\footnotetext{
${ }^{171}$ Newsom, 1996, pg. 335 / Habel, 1985, pg. 61 / Leaman, 1995, pg. 20.

${ }^{172}$ Kepnes, 2000, pg. 263 / Hartley, 1988, pgs. 47 e 48 / Pope, 1974, pg. lxxvii e lxxviii.

${ }^{173}$ Newsom, 1996, pg. 335 / Habel, 1985, pg. 62 / Dhorme, 1967, pg. cxliii.

${ }^{174}$ Glatzer, 1969, pg. 4.

${ }^{175}$ Habel, 1985, pg. 62.

176 Baskin, 1983, pgs. 8 a 10 / Pope, 1974, pg. xv e xxiii / Rowley, 1970, pg. 10 / Glatzer, 1966, pgs. 197 e 198.

177 Sobre os diferentes extratos presentes no Livro de Jó, consultar Newsom, 1996, pg. 321 / Baskin, 1983, pg. 8 / Glatzer, 1966, pg. 197 / Pope, 1974, pg. xxiv.

Sobre os paralelos entre o Livro de Jó e a literatura antiga do Egito, Suméria, Babilônia e Ugarit, consultar Pope, 1974, pgs. xxiv, xxvi, xxxiii, lvi, lviii, lxi, lxiv e lxvii / Newsom, 1996, pgs. 328 e 329 / Hartley, 1988, pgs. 7 e 8.
} 
Mesmo os diálogos poéticos, examinados como um bloco, apresentam tal complexidade interna que impedem um entendimento unívoco ${ }^{178}$. O autor usou uma técnica onde cada ponto-de-vista é apresentado como válido e convincente, para ser em seguida minado pelo oponente. Perspectivas conflitivas, ironias, ambiguidades de linguagem e complexidade do enredo - tudo isto se une para formar o que Norman Habel chamou de uma "teologia do paradoxo" 179 .

No final do livro, a resposta de Deus a Jó aprofunda ainda mais a perplexidade do leitor. A divindade ignora ${ }^{180}$ majestosamente as questões levantadas por Jó, nenhuma explicação é oferecida para sua situação e o mistério do sofrimento do justo permanece irrespondível no livro.

A validade ou não da Doutrina de Retribuição ${ }^{181}$ também não fica clara pelo epílogo. Os amigos de Jó, que através de todo o livro haviam defendido a doutrina, são criticados pela divindade por não terem dito "o que era correto". Mas, ao restituir propriedades e familia a Jó, dando um final feliz ao justo, Deus confirma as mesmas idéias defendidas pelos amigos. Deste modo, a Doutrina de Retribuição é, ao mesmo tempo, negada e confirmada no livro.

\section{$\underline{3 \text { - No Judaísmo }}$}

Os comentarios rabínicos sobre o Livro de Jó, encontrados por toda a literatura da época da Mishnah e do Talmud, também se destacam pela diversidade de interpretações. Os rabinos ${ }^{182}$ se dividiram entre aqueles que enfatizaram o Jó descrito nos trechos em prosa - extraindo daí a figura de um santo - e aqueles que destacaram o Jó dos diálogos poéticos - enfatizando um personagem rebelde e herético. "Há

\footnotetext{
${ }^{178}$ Newsom, 1996, pgs. 320, 337 e 338 / Habel, 1985, pgs. 60 e 62.

${ }^{179}$ Habel, 1985, pg. 60.

${ }^{180}$ Friedman, 1971, pgs. 121 e 122 / Newsom, 1996, pgs. 336 e 337 / Glatzer, 1969, pgs. 7 e 8 / Pope, 1974, pgs. lxxx e lxxxi / Leaman, 1995, pgs. 10 e 11.

${ }^{181}$ Friedman, 1971, pg. 122 / Newsom, 1996, pgs. 337 e 338 / Pope, 1974, pgs. Xxix e xxiii.

182 Glatzer, 1966, pgs. 197 e 198 / Baskin, 1983, pgs. 14 e 16 / Friedman, 1971, pg. 121.
} 
quase tantos Jós quanto rabinos que se pronunciaram sobre ele", escreveu Judith Baskin $^{183}$.

$\mathrm{Na}$ literatura rabínica, há ainda um outro elemento ${ }^{184}$ dividindo as opiniões sobre o personagem Jó: a percepção de cada rabino a respeito dos povos gentios. O fato do texto bíblico não identificar o personagem como um israelita ${ }^{185}$, levou os rabinos a refletirem sobre sua origem nacional. Como no Talmud encontra-se tanto visões negativas quanto positivas a respeito dos não-judeus, estas duas atitudes se refletiram nos comentários sobre o homem Jó.

Para alguns rabinos ${ }^{186}$, um homem com as qualidades de Jó só poderia ter sido um israelita, daí terem-no identificado como um profeta judeu comissionado para pregar entre os gentios. Mas para outros rabinos, Jó foi um gentio e, através dele, aprende-se quão elevado um não-israelita pode chegar a ser.

Outro ponto importante sobre Jó na literatura rabínica clássica é sua comparação com o patriarca Abraão. Enquanto alguns rabinos consideraram Jó um blasfemador, outros o tomaram como o gentio mais piedoso da história, que chegou a ultrapassar até Abraão em termos de retidão ${ }^{187}$.

Na comparação entre Jó e Abraão, a questão principal ${ }^{188}$ para os rabinos é a diferença entre servir a Deus por amor ou por medo. A visão amplamente aceita entre os rabinos é que Abraão obedecia a divindade por amor - o grau mais elevado de adoração -, mas quanto a Jó, as opiniões se dividiram. Na opinião de Yohanan ben Zakai (século I), Jó tinha um comportamento íntegro apenas por temer as consequências punitivas do pecado - ou seja, servia a Deus por medo. Mas na opinião de Yoshua ben Hananiah (século II), ele obedecia Deus por amor, como Abraão.

\footnotetext{
${ }^{183}$ Baskin, 1983, pg. 9.

${ }^{184}$ Baskin, 1983, pgs. 8 e 9.

185 Rabinos tanaim e amoraim divergiram ao opinar sobre o tempo e o lugar em que viveu o personagem Jó. As sugestões incluem a época dos Patriarcas, a servidão no Egito, o tempo dos Juízes, a Babilônia ou o período persa. Também há vozes rabínicas defendendo que Jó nunca tenha realmente existido, sendo apenas uma parábola (Baskin, 1983, pg. 13 e nota 23 / Dhorme, 1967, pgs. xx, cxiii a cxv e cliii / Pope, 1974, pgs. xxxii, xxxiv e xli / Newson, 1996, pgs. 325, 328 e 329 / Hartley, 1988, pgs. 17 e 18 / Rowley, 1970, pg. 23).

${ }_{186}$ Baskin, 1983, pgs. 10, 11, 13, 16, 18 e 20.

${ }^{187}$ Friedman, 1971, pg. 121.

${ }^{188}$ Baskin, 1983, pgs. 10, 13, 16, 18, 19 e 20 / Friedman, 1971,pg. 121.
} 
Entre os rabinos e filósofos judeus da Idade Média, prosseguiu a multiplicidade de opiniões sobre a mensagem e personalidade de Jó. O exegeta Rashi (1040-1105) viu nele um exemplo de piedade e devoção ${ }^{189}$. Já Abraham ibn Ezra (1092-1167) e Nachmânides (1194-1270) tomaram-no como um rebelde e questionador da justiça divina ${ }^{190}$.

O Zohar, obra-prima do misticismo judaico, traz em seu interior diferentes abordagens sobre Jó ${ }^{191}$. Numa passagem, o sofrimento do personagem é explicado como resultado de um erro seu, por não ter agradado Satã de forma suficiente e, assim, falhado em reconhecer a existência do mal no mundo. Em outro trecho, o Zohar explica seu sofrimento como sinal do amor divino: por considerá-lo um indivíduo íntegro, Deus quis esmagar seu corpo para fortalecer sua alma. Há ainda outras visões sobre Jó no Zohar, descrevendo-o ora como um pecador que mereceu seu castigo, ora como um inocente vitimado na qualidade de bode expiatório.

\footnotetext{
${ }^{189}$ Glatzer, 1966, pgs. 201 e 204.

${ }^{190}$ Glatzer, 1966, pgs. 204 a 206.

${ }^{191}$ Glatzer, 1966, pgs. 217, 218 e 219.
} 


\section{4 - LIVRE ARBÍTRIO (בחירה חופשית)}

\section{$\underline{\text { O Holocausto foi resultado de mau uso da liberdade humana? }}$}

A idéia de que o Holocausto representou um caso extremo de má utilização do livre-arbítrio, ou seja, da liberdade inerente à condição humana, foi amplamente esposada por pensadores judeus do Holocausto. A Shoá teria sido, segundo estes autores, o resultado de uma opção de seres humanos (nazistas e seus colaboradores) pelo mal, quando poderiam ter escolhido o bem ${ }^{192}$.

Porém, outras vozes criticaram a aplicação do conceito de livre-arbítrio no caso do Holocausto. Para estes, a idéia judaica de liberdade humana não permite tal utilização ${ }^{193}$. Vejamos qual é a definição deste conceito no judaísmo e qual foi seu desenvolvimento, a partir da Bíblia Hebraica.

A apresentação do ser humano como dotado de liberdade de escolha aparece já na história de Adão e Eva ${ }^{194}$. Os pais da humanidade decidiram livremente comer os frutos da árvore proibida, localizada no centro do jardim do Éden, desafiando a injunção de Deus (Gn 3:6).

O Livro de Deuteronômio também enfatiza a existência de liberdade de escolha para a humanidade ${ }^{195}$. Após a divindade ter definido os mandamentos, estabelecido recompensas pelo cumprimento (Dt 28:1 a 13) e castigos pela transgressão (Dt 28:15 a 68), concedeu ao ser humano poder de decisão: entre "o bem ... e o mal (...) Escolha" (Dt 30:15 e 19). Também os profetas clássicos afirmaram a liberdade do ser humano para direcionar a própria vida ${ }^{196}$.

Mas, por outro lado ${ }^{197}$, há também na Bíblia Hebraica um marcante determinismo subordinando o mundo - incluindo os seres humanos - ao poder soberano de Deus. Um exemplo é a passagem do Gênesis onde a divindade revela a Abrão que o futuro de sua descendência já está pré-determinado: os israelitas serão

\footnotetext{
${ }^{192}$ Katz, 1987, pg. 427.

${ }^{193}$ Winston, 1987, pg. 273.

${ }^{194}$ Manekin, 1997, pgs. 8 e 9.

${ }^{195}$ Winston, 1987, pgs. 269 e 270 / Avery-Peck, 1999, pg. 314.

${ }^{196}$ Cohon, 1971, pg. 309.

${ }^{197}$ Avery-Peck, 1999, pgs. 314 e 315 / Winston, 1987, pg. 269.
} 
escravizados pelos egípcios durante 400 anos e depois serão libertados (Gn 15:12 a 16), independentemente de seu comportamento moral.

Este determinismo fica ainda mais claro nas histórias bíblicas em que ocorre uma "invasão psíquica" 198 de Deus na mente de seres humanos, para influenciar suas decisões. O exemplo clássico é o do faraó contemporâneo ao Êxodo, que teve seu coração "endurecido" por Deus para que não deixasse os israelitas saírem e, assim, atraísse contra si e seu reino diversas pragas (Ex 10:1). A mesma atuação invasiva de Deus aparece em outras passagens da Bíblia Hebraica ${ }^{199}$.

Conclui-se, pois, que na Bíblia Hebraica coexistem duas visões algo contraditórias: o livre-arbítrio humano e o determinismo divino. Os autores bíblicos, aparentemente, não se perturbavam com esta situação e não se esforçaram em harmonizar as duas visões. Antes, preferiram afirmar ambas ${ }^{200} \mathrm{e}$, ao que parece, aceitavam o paradoxo resultante como parte do mistério divino ${ }^{201}$. Assim, as Escrituras podem ser definidas, no que diz respeito à liberdade humana, como um “determinismo soft" ou um "livre-arbítrio providencial" ${ }^{202}$.

O judaísmo rabínico herdou da Bíblia Hebraica esta concepção paradoxal de livre-arbítrio. Segundo o historiador Flávio Josefo, os fariseus, os antecessores históricos dos rabinos, já se diferenciavam de outras seitas judaicas - saduceus e essênios - ao afirmarem, ao mesmo tempo, tanto a liberdade humana quanto o determinismo divino ${ }^{203}$.

\footnotetext{
${ }^{198}$ Winston, 1987, pg. 269.

${ }^{199}$ Deus "endurece o espírito e torna obstinado o coração" de Sihon, rei de Heshbon (Dt 2:30) e dos canaanitas (Js 11:20) para que fossem derrotados pelos israelitas. Também adverte em sonho Abimelech a não coabitar com Sara, mulher de Abraão (Gn 20:1 a 8). Deus, desejoso de punir os israelitas, incita Davi a pecar, realizando um proibido censo populacional, e assim atrai punição ( $2 \mathrm{Sm}$ 24:1). Davi sugere a Saul que talvez fosse Deus quem criava inimizade entre os dois (1 Sm 26:19). (Winston, 1987, pg. 269)

${ }^{200}$ Winston, 1987, pgs. 270 e 271 / Avery-Peck, 1999, pg. 315 / Manekin, 1997, pgs. 8 e 9.

${ }^{201}$ Winston, 1987, pgs. 270 e 271.

${ }^{202}$ Avery-Peck, 1999, pg. 315.

${ }^{203}$ Flávio Josefo: "Havia três escolas de pensamento entre os judeus, cada uma com diferentes opiniões sobre assuntos humanos (...). Os Fariseus diziam que certos eventos são obra do Destino (Providência), mas não todos; quanto aos outros eventos, depende de nós se acontecerão ou não. A seita dos Essênios, no entanto, declara que o Destino é senhor de todas as coisas e que nada acontece aos homens sem que esteja de acordo com seu decreto. Mas os Saduceus são indiferentes ao Destino, mantendo que não existe tal coisa e que ações humanas não são realizadas de acordo com seu decreto, mas que todas as coisas estão em nosso poder e somos os responsáveis por nosso próprio bem-estar" (Josephus, 1957, pgs. 311 e 313.)
} 
No Talmud, convivem lado a lado as doutrinas da providência divina e do livre-arbítrio humano. Ao mesmo tempo em que afirmaram que nada acontece neste mundo sem que seja determinado por Deus ${ }^{204}$, os rabinos construíram sua visão de recompensa e punição baseada na idéia de que o ser humano é livre para escolher entre o bem ou o mal. Tal como na Bíblia Hebraica, a literatura rabínica clássica não se preocupou em integrar as duas concepções de forma harmônica ${ }^{205}$.

O paradoxo resultante ao se afirmar ambas doutrinas é exemplificado ${ }^{206}$ por duas passagens célebres da literatura rabínica. A primeira está na Mishnah e é atribuída a Rabi Akiva: "Tudo é previsto, mas o livre-arbítrio é concedido" ${ }^{207}$. A outra é atribuída a Rabi Hanina, no Talmud da Babilônia: “Tudo está nas mãos do Céu, com exceção do temor ao Céu" 208.

Foi somente na Idade Média, sob influência do racionalismo e da Filosofia, fortemente presentes no ambiente cultural do império muçulmano, que pensadores sefaradim se dedicaram a elaborar com mais precisão uma posição judaica sobre a questão do livre-arbítrio. A tentativa de resolução do paradoxo liberdade humanaprovidência divina, herdado da Bíblia Hebraica e da literatura rabínica, tornou-se uma questão central nas reflexões dos filósofos judeus medievais ${ }^{209}$.

Os dilemas sobre livre-arbítrio levantados por estes pensadores eram desafiadores $^{210}$ : se Deus é onisciente, conhecendo inclusive tudo o que acontecerá no futuro, o que resta de liberdade de escolha ao ser humano? Se Deus é onipotente, Ele não deveria ser a causa de tudo o que acontece no universo, incluindo as ações

\footnotetext{
Sobre o tema, consultar Pines, 2007, pgs. 232 e 233 / Avery-Peck, 1999, pg. 316.

${ }^{204}$ Mishná, Avot 5:6 - "Dez coisas foram criadas na véspera do [primeiro] shabat, no crepúsculo, e são elas: (...) o arco-íris”.

Segundo Avery-Peck, esta passagem implica que Deus já sabia o que iria acontecer no transcorrer da História, desde o momento da Criação. Ao criar o arco-íris, sabia que a corrompida geração de Noé seria exterminada no Dilúvio, com exceção do patriarca e sua família, para os quais Ele prometeria nunca mais repetir tal ato - e apresentaria o arco-íris, criado anteriormente, como prova de Sua palavra (Gn 6 a 9).

(Avery-Peck, 1999, pgs. 318 e 319.)

205 Pines, 2007, pg. 233.

${ }^{206}$ Pines, 2007, pg. 233 / Avery-Peck, 1999, pg. 317 / Winston, 1987, pg. 271.

${ }^{207}$ Mishná, Avot 3:15, original em hebraico: "הכל צפוי והרשות נתונה".

${ }^{208}$ Talmud da Babilônia, Tratado Berakhot 33b, original em hebraico: “"הכל בידי שמים, חוץ מיראת שמים".

${ }^{209}$ Cohon, 1971, pg. 317 / Manekin, 1997,pg. 10 / Hyman, 1997, pg. 133.

${ }^{210}$ Hyman, 1997, pgs. 133 e 134.
} 
humanas? Mas se Deus pré-determina as ações humanas, qual o sentido de Ele transmitir mandamentos à humanidade e responsabilizar indivíduos pelo cumprimento ou transgressão das leis?

Saadia Gaon (882-942) foi o primeiro pensador judeu a enfrentar de forma sistemática os dilemas envolvendo o livre-arbítrio. Em sua obra-prima, "O Livro de Crenças e Opiniões", após deliberar sobre o assunto, afirmou tanto a liberdade total dos seres humanos para decidir suas ações, quanto a soberania absoluta de Deus no mundo, inclusive sobre os assuntos humanos ${ }^{211}$.

A solução deste paradoxo sugerida por Saadia foi afirmar que Deus, por ser onisciente, conhece de antemão todas as decisões tomadas pelo indivíduo. Porém, a divindade não interfere nas escolhas humanas e, por isso, não é a causa. Quanto às ambiguidades retratadas na Bíblia Hebraica, como a "invasão psíquica" na mente do faraó, Saadia ignorou-as ${ }^{212}$.

Maimônides abordou a questão do livre-arbítrio em todas as suas principais obras. Para ele, afirmar a liberdade de escolha do ser humano era um ponto fundamental. Entendia-a como a característica básica que diferencia a humanidade de todas as demais criaturas terrestres, além de ser um pré-requisito para a justiça divina: sem liberdade de escolha entre o bem e o mal, não haveria sentido nos mandamentos divinos, nem nas recompensas e punições. Ao mesmo tempo, afirmou que Deus controla todos os eventos históricos e sabe de antemão qual será a escolha do indivíduo $^{213}$.

Ao contrário de Saadia, Maimônides não tentou solucionar o paradoxo da coexistência entre livre-arbítrio humano e providência divina. Afirmou que o fato do ser humano não poder harmonizar as duas doutrinas não significa que a inteligência

\footnotetext{
${ }^{211}$ Cohon, 1971, pgs. 317, 318 e 319 / Pines, 2007, pg. 231 / Altmann, 1974, pgs. 29 a 32 / Hyman, 1997, pgs. 135 a 138.

${ }^{212}$ Pines, 2007, pg. 231 / Hyman, 1997, pgs. 137 e 138 / Altmann, 1974, pg. 32.

${ }^{213}$ Cohon, 1971, pg. 322, nota 3 / Cohon, 1971, pgs. 322 e 323 / Altmann, 1974, pg. 37 / Pines, 2007, pg. 232.
} 
divina não o possa. Para o pensador, o ser humano não tem capacidade intelectual para compreender este mistério da Criação ${ }^{214}$.

${ }^{214}$ Cohon, 1971, pgs. 323 e 324 / Pines, 2007, pg. 232 / Altmann, 1974, pg. 36 / Hyman, 1997, pg. 144. 


\section{5 - MARTÍRIO OU KIDUSH HA-SHEM (קדוש השם)}

Houve possibilidade de mártírio durante o Holocausto?

Ao longo de sua história, os judeus se defrontaram por diversas vezes com forças opressoras que impuseram uma opção dilacerante: ou praticar a apostasia ou serem assassinados. Nestas situações-limite, houve judeus que decidiram pela segunda alternativa e, assim, tornaram-se mártires ou, na linguagem dos rabinos, realizaram a "santificação do nome [divino]" (em hebraico, kidush ha-Shem).

Mas, como apontaram acadêmicos e pensadores religiosos ${ }^{215}$, o Holocausto abalou mais este elemento do judaísmo. Ao contrário de perseguições do passado, desta vez não houve possibilidade às vítimas de escolher entre apostasia ou martírio. $\mathrm{O}$ nazismo condenou todos os judeus à morte, sem outra alternativa. Além do mais, como o conceito nazista de "judeu" era bastante peculiar, abrangendo desde ortodoxos e assimilados até cristãos convictos, uma parcela significativa das vítimas em guetos e campos-de-concentração morreram sem ter nenhuma consciência da noção judaica de martírio.

Levantou-se, então, a questão se houve martírio durante o Holocausto. Para entender a resposta dos pensadores examinados nesta tese para esta pergunta, vejamos neste capítulo como a idéia de kidush ha-Shem desenvolveu-se ao longo da história intelectual do judaísmo e quais são seus elementos constitutivos.

O termo clássico "santificação do nome" é uma criação do judaísmo rabínico $^{216}$. A expressão já estava presente na Bíblia Hebraica ${ }^{217}$, mas sem a

\footnotetext{
${ }^{215}$ Feld, 1994, pgs. 136 e 137 / Fackenheim, 1987, pg. 406 / Katz, 1987, pg. 425.

${ }^{216}$ Ben-Sasson, 1972, pg. 977

217 A Bíblia Hebraica desenvolve a idéia de "santificação do nome" ao lado de sua antí-tese, "profanação do nome" (em hebraico, hilul ha-Shem ou חלול השם), denotando dois aspectos complementares de um mesmo conceito.

(Ben-Sasson, 1972, pg. 977 / Firestone, 2004, pg. 291)

No Pentateuco, o sentido original de "santificação do nome" é o respeito exigido no Templo de Jerusalém, uma espécie de sistema de etiqueta comparável ao protocolo utilizado no palácio de monarcas mundanos. O povo inteiro deveria observar os detalhes dos rituais do Templo para "não profanar o santo nome" (Lv 22:18 e 32). Especialmente os sacerdotes, por se encontrarem constantemente no santuário, deveriam seguir normas rígidas de pureza para não "profanarem o santo Nome" (Lv 21:6 e 22:1).
}

(Maccoby, 1987, pgs. 849 e 850 / Firestone, 2004, pg. 291) 
conotação de sacrifício da vida em defesa da religião. $\mathrm{Na} \mathrm{BH}$, não há palavra para designar "mártir" 218 , nem há uma consciência de martírio, com exceção do tardio Livro de Daniel, que analisaremos mais adiante ${ }^{219}$.

Na Bíblia Hebraica, os personagens que mais se aproximariam da condição de mártires não chegam a preencher todos os requisitos desta definição ${ }^{220}$. O rei Saul, apesar de ter se suicidado (1Sm 31), não foi um mártir: o texto bíblico não afirma que outros se beneficiaram de sua morte, nem aguardava-o alguma recompensa no alémmundo. A morte de Sansão ( Jz 16) também não é descrita como ligada a uma recompensa além-mundo e sua atuação moral, bastante problemática, não é descrita como um exemplo a ser imitado ${ }^{221}$.

A ausência de martírio na Bíblia Hebraica é explicada por dois fatores: a inexistência de perseguição religiosa anti-judaica em quase todo o período (a exceção são as circunstâncias envolvendo o Livro de Daniel) e a ausência no pensamento bíblico da idéia de "recompensa após a morte", fundamental para o conceito de martírio $^{222}$.

No Pentateuco também há a idéia de "santificar o nome" em outras circunstâncias. Por exemplo, Moisés é proibido de entrar na Terra Santa com a justificativa de ter falhado nesta missão (Dt 32:51 e $\mathrm{Nm} 20: 12)$

(Ben-Sasson, 1972, pg. 977)

Em Ezequiel, uma outra idéia de "santificação do nome" é apresentada: Deus é quem santifica seu próprio nome, enquanto os israelitas permanecem passivos. Isto aparece em Ez 20, onde a divindade afirma que pretendeu aniquilar Israel por conta de seus vários pecados e só não o fez pois isto impediria-O de cumprir as promessas feitas anteriormente a este povo, o que "profanaria Seu nome". Segundo a Bíblia Hebraica, o aniquilamento de Israel só não se realizou por "amor do Meu nome, para que (este) não fosse profanado diante das nações no meio das quais eles (israelitas) estavam" (vv 9, 14, 22).

(Ben-Sasson, 1972, pg. 977)

Já em outros livros proféticos, a "profanação do nome" ganhou contornos fortemente morais. Em Jeremias, o descumprimento da legislação favorável aos escravos "profana o nome" (34:16) e em Amós, a opressão aos pobres e a imoralidade sexual têm o mesmo efeito (2:7).

(Maccoby, 1987, pg. 850)

${ }^{218}$ Brettler, 2002, pg. 4.

${ }^{219}$ Firestone, 2004, pg. 290.

${ }^{220}$ Reuven Firestone define martírio como morte violenta em nome da religião. O mártir é reconhecido postumamente por sua coragem e é esperado que receba uma recompensa transcedental. O mártírio tem uma forte conotação grupal e política: é um instrumento de resistência dos sem-poder ou de oprimidos contra uma autoridade estabelecida; através de seu ato, o mártir pretende deslegitimizar a autoridade e inspirar seu grupo a continuar resistindo; para ser efetivo, precisa ser um ato público.

(Firestone, 2004, pg. 289)

${ }_{221}^{221}$ Brettler, 2002, pg. 5 / Soloveitchik, Part I, 2004, pg. 97.

${ }^{222}$ Brettler, 2002, pgs. 10 e 11. 
Este quadro apenas se alterou no período tardio do Segundo Templo ${ }^{223}$, com a emergência da noção de além-vida no judaísmo, sob influência persa ou grega, e uma nova situação de perseguição contra os judeus ${ }^{224}$. A primeira mostra de intolerância anti-judaica aparece na Bíblia Hebraica com o Livro de Ester, ambientado no império persa $^{225}$. Nele, o vizir Haman acusa os judeus frente ao rei Ahashverosh de terem suas próprias leis e, portanto, não respeitar as do soberano. Daí ele aconselhar o rei a matar todos os judeus do império (Est 3:8 e 9).

O quadro se completa no Livro de Daniel, escrito no período helênico e que traz os únicos momentos de martírio da Bíblia Hebraica ${ }^{226}$. A obra fala de três judeus - Shadrakh, Meishakh e Aved-Nego - que se recusam a praticar a idolatria e colocam suas vidas em risco (Dn 3). Também o próprio Daniel é atirado numa cova de leões após desafiar um decreto real anti-judaico (Dn 6). Apesar destas passagens mostrarem primórdios de martírio, a idéia ainda não está totalmente elaborada: estes personagens são salvos no último momento; há uma mensagem otimista de que Deus sempre intervirá para salvar seu povo; não há mostras de recompensa além-vida; e os potenciais mártires não almejam realmente a morte, nem a consideram melhor que a vida $^{227}$.

É apenas durante a perseguição anti-judaica promovida pelo rei helenista Antíoco Epifanes, entre os anos 167 e 164 a.e.c., que o martírio entrou de vez no mainstream do judaísmo. É desta época ${ }^{228}$ os capítulos finais do Livro de Daniel, em que a idéia de ressurreição - essencial para o conceito de martírio - aparece explicitamente pela primeira vez na Bíblia ${ }^{229}$. O livro 1 Macabeus ${ }^{230}$, que descreve esta perseguição, já narra episódios de martírio completos e que se tornariam protótipos para o judaísmo posterior (e também ao cristianismo): Eleazar, um

\footnotetext{
${ }^{223}$ Alguns pesquisadores identificam os primórdios do martírio no judaísmo já com o profeta Segundo Isaías no século VI a.e.c. Através de sua concepção de Servo Sofredor, alguns elementos de martírio estariam presentes, como o sofrimento vinculado ao ato de testemunhar Deus e à expiação coletiva.

(Roos, 2003, pg. 66.)

${ }_{224}^{224}$ Brettler, 2002, pg. 11 e 15.

${ }^{225}$ Brettler, 2002, pgs. 11 e 12.

${ }^{226}$ Ben-Sasson, 1972, pgs. 981 e 982.

${ }^{227}$ Firestone, 2004, pgs. 290 e 291 / Brettler, 2002, pgs. 13 e 14.

${ }^{228}$ Brettler, 2002, pgs. 14 e 15.

${ }^{229}$ Daniel 12:2 e 3: "Muitos dos que dormem no pó da terra ressuscitarão, uns para a vida eterna, e outros para vergonha e horror eterno. Os que forem sábios, pois, resplandecerão como o fulgor do firmamento; e os que a muitos conduzirem à justiça, como as estrelas, sempre e eternamente".

${ }^{230}$ Ben-Sasson, 1972, pgs. 981 e 982.
} 
eminente especialista da lei judaica, escolhe o suplício da roda ao invés de comer carne de porco (6:18 a 31) e uma mãe e seus sete filhos morrem sob cruel tortura para não tocar em carne suína (7:1 a 42).

A partir de então, o martírio tornou-se um ideal religioso no judaísmo ${ }^{231}$, mesmo ainda não havendo mandamentos judaicos específicos exigindo sacrifícios deste tipo ${ }^{232}$. Filo de Alexandria (15 a 10 a.e.c. - 45 a 50 e.c.) já cita judeus que "preferem morrer na defesa de suas instituições nacionais movidos por um espírito elevado" ${ }^{233}$. Também Flávio Josefo (37 ou 38 - 100 e.c.) testemunha que, em última instância, o judeu estava preparado para morrer por sua fé ${ }^{234}$.

Apesar do forte impacto no judaísmo dos episódios de martírio sob Antíoco Epifanes, nos 300 anos seguintes não houve situação política semelhante que estimulasse novas provas-de-fé. Isto somente iria se repetir após a desastrada Revolta de Bar Kokhba (132 - 135 e.c.), que foi seguida de perseguição religiosa anti-judaica promovida pelo imperador romano Adriano ${ }^{235}$.

Deve-se notar que muito poucos judeus se aventuraram a desafiar as proibições de Adriano ${ }^{236}$ e, assim, motivar situações de martírio. Na realidade, conhecemos apenas um rabino que, coerentemente do início ao fim, desafiou o decreto de Adriano, praticando martírio: Hanina ben-Tradion, que, como punição, foi queimado vivo enrolado a uma Torá, sua mulher foi morta e sua filha colocada num bordel romano ${ }^{237}$.

\footnotetext{
${ }^{231}$ Brettler, 2002, pg. 16.

${ }^{232}$ Herr, pgs. 82 e 83.

${ }^{233}$ Roos, 2003 , pg. 67.

${ }^{234}$ Roos, 2003, pg. 68.

${ }^{235}$ Herr, pg. 74 / Rappaport, 2007, pgs. 193 e 194.

${ }^{236}$ Herr, pg. 86.
}

A perseguição promovida por Adriano incluiu a proibição de praticar circuncisão, reunir pessoas para estudar Torá, ordenar novos rabinos, organizar tribunais judaicos, ler a Torá e outros textos sagrados, colocar tefilin e mezuzah, observar o shabat, comer matzah, construir sukah, acender velas de Hanukah, soprar o shofar e vestir tsitsit.

Ou seja, proibiu-se os mandamentos positivos, do tipo "faça" (מצוות עשה). Quanto aos mandamentos negativos, do tipo "não faça" (מצוות לא תעשה), não houve coerção. Ao contrário da perseguição sob Epifanes, Adriano não obrigou os judeus a comer carne de porco, curvar-se a ídolos ou venerar o governante secular (Herr, pgs. 78 a 81).

${ }^{237}$ Talmud da Babilônia, Tratado Avoda Zara 18a: "(Os romanos) encontraram o rabino Hanina ben Tradion sentado ocupando-se com Torá, ajuntando assembléias e com um rolo da Torá em seu peito. Imediatamente o agarraram, enrolaram-no com a Torá, colocaram galhos em seu redor e atearam fogo. Eles então trouxeram lã, ensoparam em água e colocaram sobre seu coração, para que não morresse 
Durante a perseguição de Adriano, também Rabi Akiva (50 - 135 e.c.), uma das mais importantes personalidades da história do judaísmo, foi torturado e morto. Mas este suplício é entendido pelos historiadores mais como uma consequência de seu envolvimento político na rebelião de Bar Kokhba, do que como um desafio aos decretos anti-judaicos ${ }^{238}$.

Apesar da baixa ocorrência de casos de martírio registrados durante esta perseguição, as narrativas de suplício de Ben-Tradion e Akiva tornaram-se, já na geração seguinte, símbolos do sacrifício pela fé ${ }^{239}$. A idéia judaica de kidush ha-Shem do período pós-bíblico está baseada fortemente nestas poucas, mas profundas, atitudes de martírio da época ${ }^{240}$.

É neste mesmo século II e.c. ${ }^{241}$ que o judaísmo formulou suas leis clássicas sobre martírio, registradas numa célebre passagem do Talmud da Babilônia, no Tratado Sanhedrin 74ab ${ }^{242}$. É também desta época o surgimento do termo “santificação do nome" para denotar a morte pela religião judaica ${ }^{243}$.

Segundo esta passagem do Talmud ${ }^{244}$, o martírio torna-se obrigatório apenas numa situação em que um judeu seja forçado a trangredir a lei judaica, praticando um destes três atos: adorar outros deuses, praticar uma relação sexual proibida (incesto, adultério e outras infrações graves da moralidade) ou cometer assassinato. O texto

rapidamente (...) Seus discípulos clamaram: (...) 'Abra sua boca, para que o fogo entre em você (e acabe com sua agonia)'. Ele respondeu: 'Deixe que Ele que me deu (a vida), pegue-a; ninguém deve provocar ferimento em si mesmo" ".

${ }^{238}$ Herr, pg. 86.

${ }^{239}$ Herr, pgs. 89.

${ }^{240}$ Herr, pg. 73.

${ }^{241}$ Ben-Sasson, 1972, pgs. 978 e 979 / Soloveitchik, Part I, 2004, pg. 81.

${ }^{242}$ Talmud da Babilônia, Tratado Sanhedrin 74ab:

"Rabi Yohanan disse em nome de Rabi Shimon ben Yehotzadak: por maioria de votos, foi decidido (...) que a respeito de qualquer lei da Torá, se um homem for ordenado 'transgrida e sua vida será poupada', ele deve transgredir e não morrer; com exceção de idolatria, incesto (incluindo adultério) e assassinato (...) Quando veio Rav Dimi, ele falou em nome de Rabi Yohanan: foi ensinado que isto é válido apenas numa situação onde não há um decreto real (de um povo inimigo contra a prática do judaísmo). Se houver um decreto real, deve-se optar pela morte para não transgredir nem mesmo um mandamento leve. Quando veio Rabin, ele disse em nome de Rabi Yohanan: (...) [se um judeu for forçado a transgredir] em público, deve optar pela morte mesmo no que diz respeito a mandamentos leves, e não violá-los (...) O que é considerado público? (...) Dez pessoas”.

${ }^{243}$ Ben-Sasson, 1972, pg. 978.

${ }^{244}$ Ben-Sasson, 1972, pgs. 978 e 979. 
talmúdico continua: nestas situações, o judeu deve optar por morrer e não praticar estas transgressões. Mas se o judeu for forçado a praticar qualquer outro ato normalmente proibido, deve praticá-lo, e não morrer. Isto se o judeu estiver sozinho frente ao opressor ou na presença de até outros nove judeus. Mas se um judeu estiver frente a um público de dez ou mais judeus e for coagido a praticar atos contra a lei judaica sob ameaça de morte, deve escolher morrer e não praticar nem mesmo uma transgressão leve. Tudo isto vale para uma situação "normal", onde não há um regime oprimindo toda uma comunidade judaica. Mas se for esta a situação, o judeu, mesmo sozinho frente ao opressor, deve optar por morrer e não transgredir nem mesmo um mandamento leve.

Esta é a lei de martírio do Talmud, que se tornou norma no judaísmo. Nenhuma autoridade rabínica a partir de então poderia ignorá-la, nem ordenar que fosse feito menos que o exigido no texto talmúdico ${ }^{245}$. O martírio, segundo o Talmud, não é algo a ser almejado, mas é um dever que deve ser colocado acima da conservação da vida, em situações extremas ${ }^{246}$. Se um judeu falhar em se tornar um mártir como ordenado, estará "profanando o nome" ${ }^{247}$.

Em 27 de novembro de 1095, o Papa Urbano II conclamou ${ }^{248}$ a cristandade européia a libertar a Terra Santa do controle muçulmano. Na esteira dos exércitos cruzados liderados pela nobreza, bandos desorganizados de populares pilharam e massacraram os "infiéis" que encontraram pelo caminho - as comunidades judaicas do vale do Rio Reno, na França e Alemanha, que viviam na região há centenas de anos. Num espaço de dois meses, durante maio e junho de 1096, foram atacadas algumas das maiores comunidades judaicas européias da época, em cidades como Speyer, Worms, Mainz e Colônia.

Invariavelmente, os cruzados ofereciam a estas comunidades duas opções: o batismo ou a morte. Sem muita hesitação, um número significativo de judeus optou pelo suicídio. À aproximação dos cruzados, mataram suas famílias e a si próprios ${ }^{249}$.

\footnotetext{
${ }^{245}$ Soloveitchik, Part II, 2004, pg. 287.

${ }^{246}$ Maccoby, 1987, pg. 853.

${ }^{247}$ Ben-Sasson, 1972, pg. 978.

${ }^{248}$ Poliakov, 1974, Vol. I, pgs. 41 a 45 / Mintz, 1984, pgs. 85, 86 e 91.

${ }^{249}$ Mintz, 1984, pgs. 85 a 88.
} 
Esta ação dos judeus do Reno ${ }^{250}$ sobressai-se na história judaica como um ato sem precedentes, sem apoio na tradição e até mesmo violando a letra e o espírito do judaísmo talmúdico ${ }^{251}$.

O suicídio, acompanhado ainda de homicídio da própria família, nunca fora encorajado ou exigido em nenhum lugar na literatura rabínica. Quando os judeus do Reno armaram-se de facas e cortaram as gargantas de seus filhos, esposas e suas próprias, não estavam revivendo nenhum antigo preceito. O significado de seus atos era novo e espontâneo ${ }^{252}$, superando tudo o que se conhecia até então em termos de martírio judaico ${ }^{253}$.

O impacto da atitude dos judeus do Reno foi enorme para o judaísmo ashkenazi. Apesar do suicídio coletivo não ter se tornado um padrão rígido de comportamento frente a perseguições a partir de então, os mártires de 1096 fixaram um ideal pelo qual futuras condutas deveriam ser comparadas ${ }^{254}$. Essencial neste sentido foi o amplo respaldo teórico dado à ação dos judeus do Reno pelas maiores autoridades rabínicas ashkenazim das décadas seguintes ao massacre, os chamados tosafistas $^{255}$.

Os tosafistas viveram num ambiente cultural onde os mártires de 1096 já eram venerados. Mesmo que a ação suicida dos judeus do Reno não pudesse ser amparada em nenhuma halakhah existente, os tosafistas buscaram apaixonadamente fontes judaicas alternativas que pudessem defender a postura dos mártires. Do contrário,

\footnotetext{
${ }^{250}$ Mintz, 1984, pgs. 88 e 89.

${ }^{251} \mathrm{O}$ episódio anterior de suicídio coletivo em Masada (ano 73), último reduto de resistência judaica na Revolta contra Roma, é narrado apenas nos escritos em grego de Flávio Josefo, portanto eram desconhecidos dos judeus até o século XVI. É verdade que uma tradução de Josefo para o hebraico, realizada no século $\mathrm{X}$ e conhecida como Yosippon, estava bem difundida nas comunidades judaicas. Mas no Yosippon, a história de Massada traz a crucial diferença de que nela os judeus não cometem suicídio, mas sim lutam até a morte. Também, quando esta versão relata outro episódio de suicídio coletivo, na Galiléia, durante a Revolta (o próprio Josefo participou do evento, mas escapou da matança através de um ardil), o evento é apresentado como contrário aos preceitos do judaísmo (Mintz, 1984, pg. 88).

${ }^{252}$ Mintz, 1984, pg. 89.

${ }^{253}$ Katz, 1973, pg. 88.

${ }^{254}$ Mintz, 1984, pgs. 7, 89 e 98.

255 Tosafot (תוספות) - “adições". Importante coleção de comentários ao Talmud. Seus autores, os rabinos tosafistas, surgiram a partir dos descendentes e discípulos do rabino Shlomo Yitzhaqi, o Rashi (1040-1105), cuja obra serviu de base para as tosafot. Apesar da modesta designação, estas "adições" moldaram o método de estudo rabínico nos séculos seguintes e, a partir de 1530, aparecem em toda edição do Talmud
} 
teriam que considerá-los criminosos comuns, cuja punição prevista era recusar-lhes um enterro em cemitério judeu ou então sepultá-los nas extremidades, junto a outros $\operatorname{assassinos}^{256}$.

Surpreendentemente, os tosafistas deixaram ${ }^{257}$ de lado a clássica e normativa passagem do Talmud sobre martírio (no Tratado Sanhedrin 74ab, analisada acima) e buscaram fontes secundárias (agadot) para dar sustento teológico à atitude radical dos judeus do Reno ${ }^{258}$.

O tosafista Rabbenu Tam (1100-1171), uma das maiores autoridades rabínicas da história do judaísmo, afirmou que o suicído era permitido, e seria mesmo uma atitude recomendável, em situações de ameaça forçada de apostasia ${ }^{259}$. Outros tosafistas, sob o impacto do martírio de 1096, também determinaram adições à tradição judaica: em todos os casos de opressão, em que um judeu teria permissão para transgredir a lei religiosa para salvar sua vida, mesmo assim deveria escolher o martírio; e pais poderiam matar seus filhos se houvesse ameaça deles serem sequestrados pelos opressores e educados como "idólatras" 260.

A opção pelo suicídio, numa situação de opressão, tornou-se norma cultural no judaísmo ashkenazi da Idade Média ${ }^{261}$ e foi colocada em prática ocasionalmente ${ }^{262}$. Livros de reza da época passaram a incluir a benção que deveria ser recitada por um judeu, antes de assassinar seus familiares e se suicidar em kidush ha-Shem ${ }^{263}$. Mas é

\footnotetext{
${ }^{256}$ Soloveitchik, Part I, 2004, pgs. 79, 101 e 102.

${ }^{257}$ Soloveitchik, Part I, 2004, pg. 81.

${ }^{258}$ De um modo geral, no pensamento dos tosafistas, somente quando não existia halakhah prévia sobre determinado assunto é que recorreriam a agadot para dar sustento à criação de novas leis religiosas. E mesmo neste último caso, os tosafistas eram rigorosos em somente se basear em agadot que pudessem levar a conclusões lógicas e claras. Mas quanto ao martírio, eles se desviaram deste padrão. Na busca apaixonada de um sustento para a atitude das vítimas de 1096, recorreram a agadot que não se adaptavam de maneira lógica à situação. Para Haym Soloveitchik, especialista no assunto, é inevitável a conclusão de que os tosafistas manejaram as fontes para dar sustento a uma premissa concebida de antemão.

(Soloveitchik, Part I, 2004, pgs. 82, 83, 85 a 91)

${ }^{259}$ Também Rabbenu Tam utilizou uma agadah que não se adequa logicamente à situação criada pelo massacre de 1096 (Soloveitchik, Part I, 2004, pgs. 86, 87, 88, 89, 90 e 91).

${ }^{260}$ Soloveitchik, Part I, 2004, pg. 81.

${ }^{261}$ Soloveitchik, Part II, 2004, pg. 287.

${ }^{262}$ Em alguns casos, judeus acusados falsamente de utilizar sangue de cristãos na fabricação de matzot para o Seder de Pessah e de profanar hóstias durante a Idade Média optaram pelo martírio ao invés de fazer falsas admissões de culpa sob tortura (Ben-Sasson, 1972, pg. 984.)

${ }^{263}$ Ben-Sasson, 1972, pg. 984.
} 
importante ${ }^{264}$ notar que o consentimento dos tosafistas para atitudes extremas de martírio nunca se tornou uma obrigação legal no judaísmo. Os códigos clássicos de halakhah, como o Shulhan Arukh, e mesmo as compilações legais feitas pelos próprios tosafistas, não trazem menção a este assentimento, que excede a soberana lei talmúdica.

Também deve-se notar que, ao mesmo tempo em que os rabinos ashkenazim recomendavam atitudes extremas de martírio, os sefaradim adotavam uma posição bem mais moderada. Maimônides ${ }^{265}$ definiu sua posição sobre kidush ha-Shem seguindo fielmente a orientação do Talmud. Ele determinou que um judeu tinha a obrigação de preservar sua vida, mesmo em situações de opressão. Se um indíviduo optasse por atitudes radicais de martírio não-previstas pelo texto talmúdico, como suicídio ou assassinato de familiares, deveria ser considerado culpado e declarado um suicida comum.

Daí que a ação prática dos judeus sefaradim frente aos opressores foi bem diferente dos ashkenazim. Na Espanha, Portugal e Norte da África, ao enfrentar dilema semelhante aos vividos na Alemanha e França, muitos sefaradim optaram por contemporizar frente ao inimigo e fazer falsas conversões ao Islã e ao cristianismo ${ }^{266}$.

De qualquer maneira, com o fim da Idade Média, o martírio no judaísmo iniciou seu crepúsculo. O Iluminismo e o processo de secularização na Europa levaram a idéia de kidush ha-Shem a perder significado e atualidade na vida dos judeus modernos ${ }^{267}$, pelo menos até o Holocausto.

\footnotetext{
${ }^{264}$ Soloveitchik, Part II, 2004, pg. 287.

${ }^{265}$ Soloveitchik, Part I, 2004, pg. 81 / Katz, 1973, pg. 84 / Ben-Sasson, 1972, pg. 979.

${ }^{266}$ Mintz, 1984, pg. 85.

${ }^{267}$ Ben-Sasson, 1972, pg. 985.
} 


\title{
4.6 - OCULTAMENTO DA FACE OU HESTER PANIM (הסתר פנים)
}

\author{
Deus "ocultou Sua face" do povo judeu durante o Holocausto?
}

O Ocultamento da Face divina ${ }^{268}$ é apresentado na Bíblia Hebraica como um evento negativo e de consequências catastróficas. Ao "ocultar Sua face", Deus distancia-se dos assuntos humanos e deixa Israel à mercê de seus inimigos. Daí o interesse de teólogos do Holocausto em aplicar este conceito à destruição nazista. Vejamos como a idéia se apresenta nos textos clássicos do judaísmo.

Os pesquisadores bíblicos modernos ${ }^{269}$ diferenciam duas situações distintas de Ocultamento da Face na Bíblia Hebraica: numa delas, a divindade "oculta Sua Face" como forma de punição contra pecados humanos; na outra, o ocultamento acontece sem motivo aparente. Vejamos isto em mais detalhes.

A expressão "ocultamento da face" aparece 29 vezes na Bíblia Hebraica, em diferentes formas verbais. A maior concentração está nos Salmos (12 vezes), seguido dos escritos proféticos (11 vezes), Pentateuco (4 vezes) e Jó (2 vezes). Excetuando os Salmos e Jó, em todos os demais casos o Ocultamento da Face é apresentado como sendo uma resposta divina ao pecado ou desobediência de Israel ${ }^{270}$ e aparece num contexto de julgamento: Deus avalia o comportamento dos israelitas e, considerandoo negativo, suspende sua Providência. Na visão bíblica, é uma sentença justificada,

\footnotetext{
${ }^{268}$ Em três ocorrências na Bíblia Hebraica, é o homem quem “oculta a face” (Ex 3:6, Is 50:6, Is 53:3) (Balentine, 1983, pg. 45). Estes casos não serão estudados neste capítulo.

${ }^{269}$ Note-se que há pouca literatura sobre o conceito de Ocultamento da Face na Bíblia Hebraica e no judaísmo em geral, um fato que intrigou até mesmo os poucos pesquisadores do tema. Balentine afirmou que "há uma surpreendente falta de atenção a este tema nos estudos do Antigo Testamento (...) não há nada que se aproxima de um tratamento compreensivo do tópico como um todo" (1983, pg. 164). Friedman escreveu que "ninguém observou todo o processo (de Ocultamento da Face na Bíblia Hebraica) em todos os seus estágios até agora. Quando noto isto para meus colegas, estudantes e pessoas leigas, frequentemente ficam surpresos (...) A falta de tratamento deste fenômeno é, em si mesmo, algo de mistério" (Friedman, 1995, pgs. 7, 8 e 79).

Note-se, ainda, que não há verbete sobre o tema no The Anchor Bible Dictionary (1992), em The Encyclopedia of Religion (1987) e em clássicos sobre a literatura rabínica como Cohen (1995), Schechter (1961) e Urbach (1979).

${ }^{270}$ Alguns exemplos: Isaías 59:2 (“os vossos pecados esconderam o Seu rosto de vós, para que vos não ouça"), Miquéias 3:4 (“chamarão ao Senhor, mas Ele não os ouvirá, antes esconderá deles a Sua Face naquele tempo, visto que eles fizeram mal nas suas obras"), Jeremias 33:5 ("escondi o Meu rosto desta cidade por causa de toda a sua maldade"), Ezequiel 39:24 ("segundo a sua imundícia e as suas transgressões ... escondi deles o Meu rosto"), Deuteronômio 31:18 ("esconderei pois, certamente o Meu rosto naquele dia, por todo o mal que tiverem feito").
} 
dadas as advertências anteriores ao povo, como por exemplo, os profetas antes da destruição de Jerusalém em 586 a.e.c. ${ }^{271}$.

O Ocultamento da Face como julgamento está ligado à punição contra um pecado coletivo, e não individual. O transgressor punido com o abandono de Deus é um ente coletivo: a Casa de Jacó (Is 8:17), a Casa de Israel (Ez 39:23) ou a cidade de Jerusalém ( Jr 33:5). O ocultamento divino é resultado de deslealdade coletiva e, portanto, seu efeito é o abandono da comunidade ${ }^{272}$.

Deve-se notar, porém, que o Ocultamento da Face no contexto de julgamento é algo temporário na $\mathrm{BH}$, ocorrendo somente num período específico da história de Israel. Deus não é descrito como estando sempre ausente e Seu ocultamento não é uma situação "normal”. Após completada a punição, deve-se esperar uma “normalização" da relação entre povo e Deus, pois o amor divino para com Israel é eterno $^{273}$.

Como dissemos mais acima, na Bíblia Hebraica encontra-se também uma outra situação, bem distinta, de Ocultamento da Face. Especialmente nos Salmos ${ }^{274}$, o Ocultamento não está ligado a pecado ou julgamento, mas a lamento e protesto. $\mathrm{O}$ salmista, representando o inocente, afirma não ter feito nenhuma transgressão para receber como contrapartida o terrível Ocultamento da Face ${ }^{275}$.

O salmista protesta ${ }^{276}$ contra o Ocultamento da Face afirmando que não é culpado, nem se esqueceu de seus compromissos com Deus. Porém, mesmo assim, afirma que Deus se retirou do mundo. A incerteza do salmista face à esta situação se faz presente através de interrogações, que permanecem abertas e sem respostas: "Por

\footnotetext{
271 Balentine, 1983, pgs. V, 45, 65 a 67, 77.

272 Balentine, 1983, pgs. 67 e 68.

${ }^{273}$ Conforme Isaías 54:8: "Num ímpeto de indignação escondi de ti a Minha face por um momento, mas com misericórdia eterna me compadeço de ti, diz o Senhor, o teu Redentor" (Balentine, 1983, pgs. 72 e 73$)$.

${ }^{274}$ Balentine, 1983, pgs. v e 77 / Wolpe, 1997, pgs. 32 e 33.

${ }^{275}$ A expressão "ocultamento da face" aparece 12 vezes no Livro de Salmos, majoritariamente no tipo classificado como "salmos de lamento": em nove casos são salmos de lamento individual (S1 10:11, 13:2, 22:25, 27:9, 51:11, 69:18, 88:15, 102:3, 143:7.) e, em um caso, salmo de lamento comunitário (Salmo 44:25). Os dois outros casos são de salmos do tipo hino de louvor: Sl 30:8, Sl 104:29. (Balentine, 1983, pgs. 49 e 50)

${ }^{276}$ Balentine, 1983, pgs. 50, 51 e 166.
} 
que escondes a Face?" (S1 44:24) ou "Até quando ocultarás de mim o rosto?" (S1 $13: 1)$.

O Salmo 44 traz $^{277}$ um claro protesto de inocência frente ao Ocultamento da Face. Após questionar a razão desta atitude divina, o salmista nota o abandono da comunidade (v. 11: "entregaste-nos como ovelhas para o corte e nos espalhaste entre as nações"), apesar do comportamento correto do grupo em relação a Deus (vs. 17 e 18: "não nos esquecemos de Ti nem fomos infiéis à Tua aliança, não tornou atrás o nosso coração nem se desviaram os nossos passos dos Teus caminhos").

Outro exemplo ${ }^{278}$ está nos Salmos 9 e 10. Quando considerados estes dois salmos como um conjunto, o efeito do lamento (S1 10) é contrapor, ponto por ponto, as expressões de certeza expressas no louvor ( $\mathrm{Sl}$ 9). Assim, enquanto no louvor o salmista tem certeza de que Deus não esquecerá o clamor do aflito, no lamento o perverso afirma que a divindade esqueceu do povo e ocultou Sua Face (v. 11: "Deus se esqueceu, virou o Seu rosto e não verá isto nunca"). O lamento do salmista reflete uma experiência que parece inexplicável.

Como vimos mais acima, nos livros proféticos e no Pentateuco, a vítima do Ocultamento da Face é o coletivo, pois toda a comunidade transgrediu. Já nos Salmos, a vitima é o indivíduo ${ }^{279}$. Esta é mais uma evidência de que convivem na Bíblia Hebraica duas concepções diferentes para o Ocultamento da Face - como julgamento e como lamento ${ }^{280}$.

Deve-se notar, porém, que alguns pesquisadores, entre eles Sigmund Mowinckel (1884-1965), não concordam com a existência de dois tipos de Ocultamento da Face na Bíblia Hebraica. Para estes, o Ocultamento divino somente existe no contexto de julgamento. Argumentam que a razão do Livro dos Salmos não explicitar a causa que levou ao Ocultamento deve-se ao fato de que isto era sempre sabido pelo israelita da época biblica. A crença de que todo sofrimento humano é causado por algum pecado era generalizada, e isto estava tão impregnado no

\footnotetext{
${ }^{277}$ Balentine, 1983, pg. 53.

${ }^{278}$ Balentine, 1983, pgs. 54 e 55.

279 a exceção é o S1 44, que é um lamento comunitário.

${ }^{280}$ Balentine, 1983, pgs. 67 e 68.
} 
pensamento israelita, que não seria necessário explicitá-la. Daí o silêncio dos Salmos quanto à razão do desaparecimento de Deus ${ }^{281}$.

Balantine, que não concorda com esta visão e reafirma a existência de dois tipos de Ocultamento da Face, responde: "Não parece sábio adotar a teoria de que (na Bíblia Hebraica) existe em toda instância uma 'conexão inevitável' entre o pecado do crente e o Ocultamente da Face de Deus. Dadas a falta de referência a um pecado (nos Salmos), a frequente forma de interrogação destes lamentos e os protestos de inocência, pode ser sugerido que, para o salmista, o Ocultamento da Face de Deus foi percebida como uma experiência inexplicável, pelo menos em alguns casos. Precisase admitir que a evidência dos próprios Salmos não é clara neste ponto, e que, ao invés de suplementar esta evidência com certas pressuposições quanto à mentalidade hebraica, o assunto deveria continuar um tanto ambíguo" 282.

Há ainda uma outra abordagem sobre a questão do Ocultamento da Face, importante para a Teologia do Holocausto (é utilizada, por exemplo, por Irving Greenberg). Apresentada pelo crítico bíblico Richard E. Friedman ${ }^{283}$, este enfoque chama a atenção para o fato de que, no transcorrer da narrativa da Bíblia Hebraica, a divindade é descrita como gradual e naturalmente se distanciando dos assuntos humanos. De uma situação de extrema intimidade com a humanidade no Gênesis, Deus já nem é mencionado no Livro de Ester. Vejamos este desenvolvimento.

No Livro de Gênesis, Deus é apresentado como intimamente envolvido nos assuntos mundanos. A divindade sopra pessoalmente vida no primeiro homem (2:7), forma a primeira mulher, planta o Jardim do Éden e cria os animais. Deus anda pessoalmente pelo Éden e os homens escutam o Seu som (3:8). Na história do Dilúvio, já não há o mesmo grau de intimidade, mas a divindade ainda fala com Noé, fecha a arca pessoalmente $(7: 16)$ e estabelece uma Aliança com todas as criaturas da

\footnotetext{
${ }^{281}$ Balentine, 1983, pgs. 52 e 55.

282 Balentine, 1983, pg. 56. Concordam com esta idéia Wolpe (1997, pgs. 32 e 33) e Friedman, que afirma: "O quadro bíblico não é simplista, não podemos afirmar simplesmente que na Bíblia o homem se comporta mal e então Deus pune-o pela remoção de Sua presença” (Friedman, 1995, pg. 98).

${ }^{283}$ Friedman, 1995, pgs. 7 a 28.
} 
Terra (9:8 a 17). Na história subsequente da Torre de Babel, Deus "desce" ao mundo para observar a construção (11:5).

Com o crescimento populacional das gerações seguintes, a presença divina nunca mais se fará visível à toda a humanidade. Por isso, Deus faz uma segunda Aliança com um indivíduo, Abraão, com o objetivo explícito de que esta relação acabará beneficiando as demais famílias da terra $(12: 3 ; 18: 18 ; 28: 14)$. Quanto à geração de israelitas que sai do Egito liderada por Moisés, a presença divina é descrita como um fato manifesto. Esta geração é apresentada na Bíblia como tendo testemunhado milagres evidentes durante 40 anos. Isto culmina numa última experiência de Deus para uma grande massa de pessoas - a Revelação no Monte Sinai. A divindade "desce" pessoalmente na montanha em fogo (Ex 19:11, 18 e 20) e fala em alta voz do céu para milhares de israelitas embaixo (Ex 19:19, 20:1 e 22).

Mas após este episódio, a presença explícita de Deus começa a diminuir. A cena de um povo ouvindo a voz divina não se repetirá mais na Bíblia Hebraica. Neste momento, nasce a profecia como instituição, ou seja, a comunicação mediada entre a divindade e a comunidade através de um indivíduo eleito.

Quando o povo israelita se assenta na Terra Prometida, comandados por Josué, os sinais que restaram da presença divina continuam a diminuir. O Livro de Juízes inclui milagres ocasionais e aparições de anjos, mas trata-se de uma época de menos sinais extraordinários. Há alguns milagres também no início do livro 1Samuel, mas em 2Samuel, quase nenhum. A presença cada vez menor de Deus se acelera a partir deste ponto.

A última pessoa para quem é dito que Deus se "revelou" é Samuel (1Sm 3:21). A última pessoa de quem é dito que Deus "apareceu” é Salomão (1Reis 3:5; 9:2; 11:9). O último milagre público, testemunhado por todo o povo de Israel ou por pelo menos boa parte, é a história do profeta Elias no Monte Carmel (1Reis 18). A narrativa sobre Elias também inclui a última aparição de um anjo (2Reis 1:3 e 15). Nos poucos relatos envolvendo anjos após este episódio, não se se sugere que foram vistos por alguém (2Reis 19:35). 
A história de Eliseu, sucessor de Elias, marca uma transição: os milagres pessoais substituem os grandes milagres públicos das narrativas anteriores. Estes milagres individuais são testemunhados por poucas pessoas e também servem ao interesse de poucos. Eventualmente, também os milagres pessoais cessam. Numa história envolvendo o profeta Isaías, cerca de um século após Eliseu, o rei judeu Ezequias pede um sinal que confirme a profecia de Isaías (2Reis 20:8 a 11). Este é o último milagre na narrativa bíblica.

A narrativa envolvendo Isaías e Ezequias também inclui o último relato de um anjo atuando na terra, agora sempre invisível, como foi dito acima. Neste episódio, o anjo ataca o acampamento do exército assírio durante a noite, para pôr fím ao cerco contra Jerusalém (2Reis 19:35; Is 37:36; 2Cr 32:21). Após este evento, anjos aparecerão apenas em sonhos e visões. O único canal visível restante de comunicação com Deus é o Templo de Jerusalém, mas este é destruído pelos babilônios.

Os profetas clássicos aparecem no palco da História numa época avançada do gradual ocultamento divino. A divindade já não aparece a mais ninguém e, portanto, a experiência profética se dá apenas através de visões e sonhos. A expressão "E o Senhor apareceu a X" nunca ocorre em nenhum dos livros dos profetas clássicos.

Quanto aos últimos livros da Bíblia Hebraica, Ezra e Neemias não trazem milagres, anjos ou aparições divinas. O Templo é reconstruído, mas a "nuvem e glória" divinas não aparecem no dia de sua inauguração, como aconteceu no Templo de Salomão (1Reis 8:10 e 11). Já no Livro de Ester, Deus sequer é mencionado. Neste contexto geral, o Livro de Daniel é uma grande exceção, pois inclui alguns milagres. 


\section{7 - POR CAUSA DE NOSSOS PECADOS (מפני חטאינו)}

\section{$\underline{\text { O Holocausto foi punição divina por pecados do povo judeu? }}$}

A idéia de que a Shoá foi um ato coordenado por Deus, como uma punição por algum pecado do povo judeu, ronda toda a Teologia Judaica do Holocausto, quer como uma idéia possível, quer como uma idéia a ser repudiada. De modo geral ${ }^{284}$, pode-se dizer que o argumento tem sido esposado por alguns rabinos ultra-ortodoxos (apesar de não haver consenso entre eles sobre qual teria sido o pecado ${ }^{285}$ ), enquanto a totalidade dos pensadores de tendência moderna rejeita-o radicalmente.

A presença marcante do modelo pecado-punição na Teologia do Holocausto tanto para abraçá-lo quanto para refutá-lo - deve-se ao seu profundo arraigamento na religião judaica. Este modelo explicativo para catástrofes coletivas é encontrado já nos extratos mais antigos da Bíblia Hebraica e foi posteriormente também desenvolvido pela literatura rabínica. Vejamos com mais detalhes sua evolução.

Na Bíblia Hebraica, a explicação mais comum para os revéses na vida de uma comunidade é através do padrão "pecado humano seguido de punição divina" 286. Apesar de não ser a única explicação para infelicidades coletivas ${ }^{287}$, é a mais central no pensamento bíblico. Assim, encontramos este modelo como explicação para as agruras dos descendentes de Adão e Eva (Gn 3), para a eliminação da geração do dilúvio (Gn 6), na destruição de Sodoma e Gomorra (Gn 18), na errância pelo deserto após o Êxodo (Nm 13), entre muitos outros exemplos.

Os autores da BH também usaram este conceito para explicar o maior desastre nacional israelita da era bíblica - a destruição do Templo de Jerusalém pelos babilônios e o consequente exílio da população de Judá. Esta utilização é encontrada

\footnotetext{
${ }^{284}$ Eshkoli, 2003, pgs. 448 e 449.

${ }^{285}$ Enquanto o rabino Elchanan Wasserman apontou como o pecado desencadeador do Holocausto o movimento de Reforma do judaísmo, Yoel Teitelbaum apontou para o sionismo e Issachar Teichtal, para o anti-sionismo.

(Eshkoli, 2003, pgs. 445, 448 e 449 / Katz, 1987, pgs. 426 e 427).

${ }^{286}$ Kraemer, 1995, pgs. 18, 19 e 22 / Goldenberg, 1982, pg. 517 / Sklar, 2005, pg. 11.

287 A escravidão dos israelitas no Egito durante 400 anos não é apresentada como uma punição por pecados, mas sim decorrência de um destino pré-ordenado pela Aliança com Abraão (Gn 15:13 e 14).
} 
especialmente em dois blocos literários: os profetas clássicos e a escola deuteronomista $^{288}$.

Os profetas afirmaram com convicção que calamidades nacionais deveriam ser entendidas como punição divina por pecados coletivos ${ }^{289}$. O Primeiro Isaías explicou a invasão assíria (ano 722 a.e.c.), que destruiu o reino de Israel e quase extinguiu o reino de Judá, como um castigo de Deus por transgressões ${ }^{290}$. Jeremias e Ezequiel, contemporâneos da destruição do Templo e do início do exílio, explicaram estas catástrofes através do mesmo modelo ${ }^{291}$.

O Segundo Isaías, que viveu no exílio da Babilônia, utilizou o mesmo modelo para explicar a perda da independência ${ }^{292}$. Idem para as dificuldades após o retorno a Sião em Ageu, o ataque de inimigos em Oséias, a falta de chuvas em Amós e o futuro sombrio previsto por Miquéias ${ }^{293}$.

O modelo explicativo pecado-punição também está no cerne do pensamento ${ }^{294}$ da chamada escola deuteronomista - as gerações de escritores e historiadores israelitas dos séculos VII e VI a.e.c. responsáveis pelos livros Josué, Juízes, 1 e 2 Samuel, 1 e 2 Reis. Neste bloco literário, todos os reveses nacionais durante mais de 600 anos de história bíblica ${ }^{295}$ são explicados como castigos divinos por mau comportamento do povo e seus líderes.

No período pós-bíblico, quando os rabinos buscaram explicações para as catástrofes nacionais de seu próprio tempo, o modelo mais sugestivo que herdaram foi o de pecado-punição ${ }^{296}$. Na única passagem da Mishnah onde é sugerida uma

\footnotetext{
${ }^{288}$ Cover, 1992, pgs. 36 e 39.

${ }^{289}$ Cover, 1992, pg. 39 / Goldenberg, 1982, pg. 517 / Bright, 2000, pgs. 296, 297, 333 e 338 / Kraemer, 1995, pg. 21 / Sawyer, 1993, pgs. 48 e 49.

${ }^{290}$ Is $3,5: 24$ a $29,8: 5$ a $8,10: 5$ a 12 .

${ }^{291}$ Jr 21:1 a 10, Jr 52:2 e 3, Ez 39:23.

${ }^{292}$ Is $42: 24$ e $25,48: 17$ a 19.

${ }^{293} \mathrm{Am}$ 4:6 a 11, Os 8:1, Mq 1:1 a 6, Ag 1:10 e 11 .

${ }^{294}$ Neeman, 2002, pgs. 43 a 68 / Weinfeld, 1992, pgs. 1 a 4 / Kraemer, 1995, pgs. 20 e 21 / Person, 2002, pg. 104

${ }^{295}$ O Livro de Juízes explica todas as derrotas das tribos israelitas durante 200 anos como resultado do pecado de idolatria (Jz 2:10 a 23). O Livro de Reis consolida este modelo explicativo ao aplicá-lo tanto à destruição do Reino de Israel pela Assíria em 722 a.e.c. (2Reis 17:7 a 23) quanto à tomada de Jerusalém pelos babilônios em 586 a.e.c. (2Reis 21:1 a 16).

${ }^{296}$ Kraemer, 1995, pg. 22 / Goldenberg, 1982, pg. 517.
} 
explicação para a destruição do Segundo Templo de Jerusalém o texto indica implicitamente que foi punição divina por pecados ${ }^{297}$. Também o Talmud de Jerusalém, compilado por volta do ano 400, nas duas passagens em que aborda o mesmo tema, a explicação é punição divina por pecados ${ }^{298}$.

Porém, ainda durante o período talmúdico, o modelo pecado-punição começou a ser questionado. Lamentações Rabbah, uma obra de midrashim ${ }^{299}$ rabínicos compilada em algum momento entre os séculos V e VII e que traz como tema central a destruição do Segundo Templo, ainda explica a catástrofe quase que exclusivamente através do modelo "por causa de nossos pecados". Mas a obra abriu espaço também para consideração de causas naturais e políticas, como um ódio irracional dos romanos contra os judeus ${ }^{300}$.

Esta tímida contestação do modelo pecado-punição tomou corpo no Talmud da Babilônia ${ }^{301}$, uma obra marcada justamente por um espírito independente e inovador. No TB, há quatro passagens principais ${ }^{302}$ tratando da destruição do Templo de Jerusalém. Na primeira delas, no Tratado Yoma 9b, está presente o tradicional modelo pecado-punição:

Por que o Primeiro Templo foi destruído? Devido a três coisas que aconteciam ali: idolatria, imoralidade e derramamento de sangue (...) Mas o Segundo Templo, onde se ocupavam com Torá, cumprimento de mandamentos e boas ações, por que foi destruído? Por que ali havia ódio gratuito. Isto nos ensina que ódio gratuito é considerado de mesma gravidade que idolatria, imoralidade e derramamento de sangue, juntos.

\footnotetext{
${ }^{297}$ Esta passagem da Mishnah (Taanith 4:6 e 7) determina que se jejue no dia da destruição do Templo, dia 9 do mês de Av. Como a Mishnah também determina jejum para o Dia do Perdão (Yoma 8:1), conclui-se por analogia que 9 de Av é um dia de expiação por pecados (Kraemer, 1995, pg. 60).

${ }^{298}$ Talmud de Jerusalém, Tratado Yoma 1:1 (38c) e Tratado Taanit 4:5 (68c-69a) (Kraemer, 1995, pgs. 105 a 108).

${ }^{299}$ Midrash (מדרש), pl. midrashim - do verbo hebraico "examinar, investigar". Método rabínico de interpretação da Bíblia Hebraica para elucidar assuntos legais (midrash halakhah) ou apresentar lições morais (midrash agadah). Usualmente, estas interpretações rabínicas concentraram-se em livros bíblicos específicos. Posteriormente ordenadas, deram origem a vários volumes da coleção também nomeada midrashim (p.e., Genesis Rabbah, Lamentações Rabbah, Ester Rabbah etc).

${ }^{300}$ Kraemer, 1995, pgs. 140, 141, 142, 146 / Cohen, 1982, pgs. 25 a 29.

${ }^{301}$ Goldenberg, 1982, pgs. 519, 522, 523 e 525.

${ }^{302}$ Kraemer, 1995, pgs. 150, 176 a 179, 209 / Goldenberg, 1982, pgs. 519 e 520.
} 
Mas na mesma página do Talmud, um pouco mais adiante, a certeza sobre as causas da destruição do ano 70 já se encontra diluída. Rabinos comparam a destruição do Primeiro Templo ("primeiros") com a do Segundo Templo ("últimos") e deixam transparecer perplexidade sobre as causas da catástrofe mais recente ${ }^{303}$ :

Rabi Yohanan e Rabi Eleazar, ambos disseram: "Os primeiros, cujos pecados foram revelados, seu fim foi revelado ${ }^{304}$. Os últimos, cujos pecados não foram revelados, seu fim não foi revelado. Rabi Yohanan disse: "A unha dos primeiros era melhor que o corpo dos últimos". Disse Resh Lakish a ele: "O contrário, os últimos foram melhores; apesar de viverem oprimidos, ocupavam-se com o estudo da Torá”

A mesma dificuldade ${ }^{305}$ em determinar o pecado que resultou na destruição do Templo ${ }^{306}$ está presente em outro momento do Talmud da Babilônia. No Tratado Shabat 119 b, oito importantes rabinos amoraim ${ }^{307}$ fornecem oito diferentes razões exclusivas para a catástrofe (na forma "Jerusalém foi destruída apenas porque...”), transmitindo incerteza sobre a verdadeira causa ${ }^{308}$.

Mas é numa quarta passagem talmúdica ${ }^{309}$, numa longa exposição presente no Tratado Gittin 55b-58a, que o modelo pecado-punição é colocado de lado para dar espaço a uma explicação política para a destruição do Segundo Templo. Aqui, o Talmud conta a história de uma inimizade pessoal entre dois judeus da época, Kamtza e Bar-Kamtza, que dispara uma série de eventos, culminando em intervenção romana e na destruição de Jerusalém. A divindade tem uma atitude passiva em toda a

\footnotetext{
${ }^{303}$ Goldenberg, 1982, pg. 524.

${ }^{304}$ menção ao fim do exílio babilônico, no ano 538 a.e.c. Em seguida, o texto talmúdico nota que o segundo exílio continua.

${ }^{305}$ Goldenberg, 1982, pgs. 519 e 520.

${ }^{306}$ o texto talmúdico não esclarece qual o Templo cuja destruição se discute, o Primeiro ou o Segundo.

${ }^{307}$ Amora (אמורא), pl. amoraim - do aramaico, "orador, intérprete". Destacados rabinos que sucederam os tanaim, a partir da edição da Mishnah (ano 200). Foram os autores do Talmud de Jerusalém e do Talmud da Babilônia.

${ }^{308}$ Talmud da Babilônia, Tratado Shabat 119b: “Abaye disse: Jerusalém foi destruída apenas porque ali se profanava o shabat (...) Rabi Abahu disse: Jerusalém foi destrúida apenas porque se negligenciava as preces de Shema matutina e vespertina (...) Rav Hamnuna disse: Jerusalém foi destrúida apenas porque eram indiferentes com as escolas infantis (...) Ulla disse: Jerusalém foi destrúida apenas porque não se tinha vergonha um do outro (...) Disse Rabi Itzhak: Jerusalém foi destrúida apenas porque pequenos e grandes eram considerados iguais (...) Rabi Hanina: Jerusalém foi destrúida apenas porque não se repreendiam (...) Rav Yehuda: Jerusalém foi destrúida apenas porque se desprezava os eruditos (...) Raba: Jerusalém foi destrúida apenas porque terminaram os homens de fé".

${ }^{309}$ Kraemer, 1995, pgs. 179 a 182 / Goldenberg, 1982, pgs. 520 e 521.
} 
passagem e a conclusão inevitável é de que a catástrofe teve razões essencialmente naturais.

Foi somente na Idade Média que o judaísmo consolidou um modelo alternativo ao de pecado-punição. Após o massacre das comunidades do vale do Rio Reno pelos cruzados, a partir do ano 1096, os escritores que memorializaram estes eventos recusaram-se a aplicar o tradicional modelo a esta catástrofe.

As comunidades ashkenazim vítimas das hordas cruzadas tinham uma autoimagem bastante elevada. Consideravam-se um modelo exemplar, com alto nível de apego aos textos sagrados e viam-se como judeus totalmente dedicados aos mandamentos religiosos. Quando a tragédia abateu-os, tanto eles próprios quanto seus memorialistas não aceitaram explicar o amargo destino através de "punição divina por pecados cometidos" 310 .

Nos textos medievais que exaltam estas comunidades não há identificação de qualquer pecado que pudesse ter atraído tamanha catástrofe ${ }^{311}$. Os memorialistas preferiram explicar o evento através de conceitos alternativos, como "aflição por amor" e "sacrifícios de animais sagrados" (estes conceitos serão vistos em detalhes mais adiante, no capítulo "Três Elementos para Pensar a Contradição entre os Rabinos").

O modelo "por causa de nossos pecados" continuou sendo utilizado por pensadores judeus para explicar novas catástrofes, como a Expulsão da Espanha em 1492. Mas também neste caso, estes autores utilizaram modelos alternativos, como a astrologia e cabala (também veremos isto em detalhes no capítulo "Três Elementos para Pensar a Contradição entre os Rabinos") ${ }^{312}$.

Na Era Moderna, num ambiente de forte secularização, o modelo pecadopunição caiu em desuso fora dos círculos ultra-ortodoxos mais conservadores. Mas é interessante notar que o conceito continua vivo no serviço sinagogal, onde é reiterado

\footnotetext{
${ }^{310}$ Mintz, 1984, pg. 91 / Mintz, 1987, pgs. 43 e 44 / Marcus, 1982, pg. 47.

${ }^{311}$ Mintz, 1984, pg. 91.

312 Rosenberg, 1983, pgs. 402, 404, 405, 406, 417 e 418 / Schweid, 1994, pgs. 312 e 313 / Scholem, 1975 , pgs. 15,18 e 19.
} 
por todo judeu presente nas preces. A idéia aparece na reza Shaharit shel Hol, pronunciada sempre nas manhãs de segunda-feira e quinta-feira: "Devido aos nossos pecados e às trangressões de nossos pais, Jerusalém e seu povo se tornaram uma vergonha entre todos que nos cercam" ${ }^{313}$. Os fiéis repetem a mesma idéia através da prece feita durante os principais feriados judaicos (Mussaf Shlosh Regalim), no Ano Novo (Mussaf Rosh HaShanah) e no Dia da Expiação (Mussaf Yom Kipur): "Por causa de nossos pecados, fomos exilados de nossa terra" ${ }^{314}$.

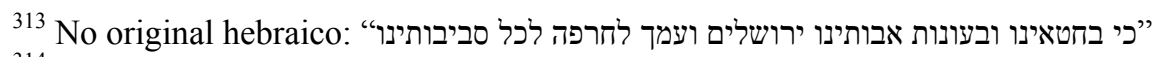

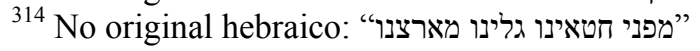




\section{8 - SIGNIFICADO RELIGIOSO DO ESTADO DE ISRAEL}

Qual o significado da criação de um Estado judeu três anos após o Holocausto?

O judaísmo tradicional ${ }^{315}$ aguarda uma era messiânica no futuro, caracterizada por redenção e paz universais. Nesta nova fase da humanidade, todo o povo judeu retornará à sua terra ancestral, cujas fronteiras serão ainda maiores que os atuais territórios israelense e palestino. Lá, todos viverão de acordo com a halakhah. Liderados por uma personalidade religiosa, o messias, os judeus não sofrerão mais nenhum tipo de opressão e todas as demais nações do mundo apoiarão esta iniciativa de retorno à terra ancestral. A redenção dos judeus virá acompanhada de redenção universal $^{316}$.

Diante deste quadro ${ }^{317}$, o que aconteceu a partir de 1948 , com a criação do Estado de Israel, foi algo parcial e interrompido. Liderados por um movimento nãoreligioso (sionismo), apenas parte do povo judeu decidiu imigrar à Terra de Israel, onde puderam se instalar em apenas parte da Terra Prometida e onde somente uma minoria guia suas vidas pela halakhah. Além disso, o país vive um conflito ininterrupto com seus vizinhos árabes.

A concretização do projeto sionista, através da criação do Estado de Israel, colocou frente ao judaísmo tradicional ${ }^{318}$ a delicada questão de interpretar os fatos históricos a partir de 1948. Pensadores ortodoxos se perguntaram se os judeus ainda viviam em exílio, numa época onde passou a existir um Estado judeu independente. Também se questionaram se a criação de Israel estaria assinalando, pelo menos, o começo da redenção (אתחלתא דגאולה).

O Holocausto aumentou ainda mais a perplexidade ortodoxa frente ao fenômeno sionista. Haveria algum significado religioso entre a destruição do judaísmo europeu e a criação do Estado de Israel, logo em seguida? O massacre dos judeus europeus poderia ter sido um castigo divino motivado justamente pela

\footnotetext{
${ }^{315}$ Este capitulo é baseado na obra Haketz Hameguleh U-Medinat HaYehudim, de Aviezer Ravitzky. O autor é professor de Estudos Judaicos da Universidade Hebraica de Jerusalém e ganhador do Prêmio Israel - o mais importante do país - na categoria Pensamento Judaico, no ano 2001.

${ }_{316}^{316}$ Ravitzky, 2001, pg. 11.

${ }^{317}$ Ravitzky, 2001, pg. 11 / Sacks, 1993, pgs. 55 a 57.

${ }^{318}$ Ravitzky, 2001, pgs. 11 e 12.
} 
"rebeldia" do movimento sionista? Ou o contrário, o estabelecimento do país foi uma compensação divina após a Shoá?

Desde o momento em que foi apresentado publicamente pelo jornalista austríaco Theodor Herzl, na Basiléia, em 1897, o sionismo recebeu fortes críticas da grande maioria dos rabinos ortodoxos. Eles frisaram a desobediência sionista aos Três Juramentos ${ }^{319}$, uma célebre proibição rabínica contra a imigração em massa de judeus à Terra de Israel antes da era messiânica.

Porém, a postura da ortodoxia se transformou à medida em que o movimento sionista se consolidou e, por fim, estabeleceu o Estado de Israel como fato consumado. O Holocausto também influenciou na transformação da postura ortodoxa frente ao sionismo. Como consequência, os ortodoxos se dividiram em três grandes

${ }^{319}$ Segundo o Talmud e outras fonte rabínicas, o povo judeu e as nações do mundo teriam feito três
juramentos ante Deus, no início do exílio judaico (ano 70): os judeus prometeram não forçar a volta à
Terra do Israel antes do tempo messiânico ("não subir os muros") e não se revoltar contra os povos
entre o quais viviam exilados; já as demais nações juraram não maltratar os judeus "em demasia".
O Talmud da Babilônia, Tratado Ketubot 111 la, traz esta célebre passagem: "Três Juramentos: Um, que
Israel não suba os muros; o segundo, que [Deus] fez Israel jurar que não se rebelaria contra as nações
do mundo; e o terceiro, que [Deus] fez os idólatras jurarem que não oprimiriam Israel em demasia".
Os Três Juramentos, transmitidos pela literatura rabínica, atuaram durante os séculos de exílio de duas
maneiras: como consolo para a difícil situação existencial vivida pelos judeus e como barreira contra movimentos messiânicos de imigração em massa para a Terra de Israel.

No judaísmo medieval em terras muçulmanas, entre os anos 600 e 1100, a imigração judaica para a Terra de Israel foi fenômeno raro. Porém, logo em seguida, vemos Maimônides utilizando os Três Juramentos para tentar demover um movimento de imigração de tendência messiânica que aflorou na comunidade judaica do Iêmen.

No século XIII, outro rabino de renome, Moshe ben Nachman, o Nachmânides, deixou sua comunidade em Girona (Espanha) e imigrou para a Terra de Israel. Ele foi o primeiro a legislar que assentar-se na Terra Santa era um mandamento divino para o indivíduo judeu. De tendência cabalista, Nachmânides sublinhou o significado místico da vida religiosa na Terra de Israel e decretou que a imigração era uma "mitzvah positiva que todos estão obrigados, para todas as gerações, mesmo em época de exílio".

Assim, solidificou-se no judaísmo a distinção entre a louvável imigração individual à Terra de Israel por motivos religiosos e a condenável imigração coletiva, que desafiava os Três Juramentos.

No século XV, uma nova onda de imigração judaica, desta vez causada pelas perseguições na Espanha, levou novamente à condenação rabínica baseada nos Três Juramentos.

No século seguinte, um importante rabino, Yeuda Loew, o Maharal de Praga, reforçou a validade dos Três Juramentos ao conceder-lhes conotações místicas. Para Loew, os Três Juramentos tinham a função de evidenciar a singular existência judaica, diferenciada de todas as demais nações.

Moses Mendelssohn, o promotor do Iluminismo judaico, reforçou a validade dos Três Juramentos. Ele afirmou que "nossos sábios proibiram qualquer ação direcionada ao retorno do povo e sua restauração à força".

No século seguinte, o rabino Shimshon Raphael Hirsch, pai da neo-ortodoxia na Alemanha, adotou posição similar.

Deve-se ressaltar que a proibição de imigração derivada dos Três Juramentos sempre teve caráter mais ideológico e teológico do que propriamente legal no judaísmo. A proibição não chegou a ser incorporada realmente no corpus legal rabínico.

(Ravitzky, 2001, pgs. 39, 40, 41, 43, 277 a 305) 
grupos no que concerne ao Significado Religioso do Estado de Israel ${ }^{320}$. Vejamos cada um deles.

\section{1 - $\underline{\text { Ortodoxos anti-sionistas }}$}

O precursor ${ }^{321}$ da ortodoxia anti-sionista foi o rabino húngaro Chaim Elazar Shapira (1872-1937). Para ele, a imigração de judeus em massa para a Terra de Israel, ainda mais sob a liderança de não-religiosos como os sionistas, representava a condenável ação de forçar o Final dos Tempos (דחיקת הקץ). Em sua visão, os judeus deveriam esperar pacientemente por intervenção divina e ser totalmente passivos do ponto-de-vista político. A imigração à Terra de Israel somente poderia acontecer na era messiânica, quando ocorreria de forma supranatural.

O rabino Shapira ${ }^{322}$ via a Terra de Israel como um lugar único no mundo, dotado de uma sacralidade incomum. Inspirado pela mística judaica, afirmou que a Terra Santa é um lugar especial onde acontece um choque frontal entre forças divinas e satânicas. Viver ali representaria até um perigo de vida para o judeu "mediano". Se este pecasse na Terra de Israel, deveria esperar um castigo divino bem mais rigoroso do que se transgredisse fora dela. Nem mesmo seus discípulos tinham estatura moral para viver ali e Shapira advertiu-os, em 1937, às vésperas do Holocausto, a não se aventurarem a imigrar para a Palestina.

Daí ser inconcebível para Shapira ${ }^{323}$ que a reconstrução da Terra de Israel fosse realizada através de um movimento secular como o sionismo. Ao invés de redenção, o movimento sionista levaria a uma destruição espiritual e a um exílio ainda piores que os de sua época.

\footnotetext{
${ }^{320}$ A exposição destas tres linhas ortodoxas está baseada no livro Haketz Hameguleh U-Medinat HaYehudim, de Ravitzky. O autor não organizou sua exposição explicitamente em três escolas, mas isto é decorrência lógica de sua apresentação. Também, Ravitzky aconselhou o autor desta tese, em carta datada de 5/1/06, a organizar a exposição desta maneira (em três escolas).

${ }^{321}$ Ravitzky, 2001, pgs. 62, 69 e 70.

${ }^{322}$ Ravitzky, 2001, pgs. 67, 68, 71 e 72.

${ }^{323}$ Ravitzky, 2001, pgs. 67, 68 e 70.
} 
A visão anti-sionista de Shapira teve boa acolhida entre a comunidade judaica ashkenazi que vivia na Cidade Velha de Jerusalém, no início do século XX ${ }^{324}$. Esta comunidade já andava desgostosa há algumas décadas pela chegada de imigrantes sionistas seculares na cidade. Chamavam a si próprios de "extremistas" (קנאים), isolavam-se e se sentiam como uma minoria que deveria carregar os verdadeiros valores judaicos.

Em 1938, quando a liderança política sionista na Palestina impôs ${ }^{325}$ um novo imposto sobre a população judia local destinado a financiar atividades militares contra os árabes, a comunidade ortodoxa anti-sionista ashkenazi de Jerusalém recusou-se a pagar. Basearam a sua recusa numa passagem do Talmud de Jerusalém, Tratado Hagigah 1:7 :

O rabino Yehuda Ha-Nasi enviou os rabinos Haya, Asi e Ami para passar pelas cidades da Terra de Israel a fim de estabelecer escribas e instrutores (da Torá). Chegaram a certo lugar e não encontraram nenhum escriba ou instrutor. Pediram (aos habitantes): Envie-nos os guardiões da cidade (naturei karta, no aramaico original). Apresentaram então os guardiões (militares) da cidade. (Os rabinos) disseram: São estes os guardiões da cidade? Estes não passam de destruidores da cidade. (Os habitantes) disseram: E quem são os guardiões da cidade? (Os rabinos) disseram: Os escribas e instrutores, conforme está escrito (em Salmos 127:1 e 2): 'Se o Senhor não edificar a casa [em vão trabalham os que a edificam; se o Senhor não guardar a cidade, em vão vigia o sentinela'].

(grifos meu, AF)

O termo Naturei Karta ("guardiões da cidade") até hoje identifica o grupo ortodoxo anti-sionista mais radical do Estado de Israel, concentrado em Jerusalém. Consideram ${ }^{326}$ os sionistas a partir da passagem talmúdica acima, ou seja, como "destruidores da cidade", indivíduos que desafiaram os Três Juramentos ("rebelaramse contra as nações") e, com isso, romperam o modus vivendi que existia anteriormente com os vizinhos árabes.

\footnotetext{
${ }^{324}$ Ravitzky, 2001, pgs. 74, 75, 77, 79.

${ }^{325}$ Ravitzky, 2001, pg. 86.

${ }^{326}$ Ravitzky, 2001, pg. 87.
} 
Para estes ortodoxos anti-sionistas ${ }^{327}$, o povo judeu deveria continuar à margem da política ${ }^{328}$ e concentrar-se apenas no cumprimento dos mandamentos religiosos, esperando pacientemente pela redenção. Consideram que a situação de exílio não é resultado de poder político, mas de pecados do próprio povo judeu. Portanto, a redenção também não virá através da força, mas sim do arrependimento (tshuvah ${ }^{329}$ ).

\section{2 - $\underline{\text { Ortodoxos sionistas }}$}

Já os ortodoxos sionistas ${ }^{330}$ consideram o movimento político fundado por Herzl não como um projeto humano, mas sim como uma iniciativa de redenção guiada por Deus. Afirmam que o sionismo inaugurou uma nova fase da história judaica, marcada pela liberação dos Três Juramentos e pelo fim da passividade política ${ }^{331}$. Consideram a criação do Estado de Israel como a materialização da visão de redenção dos profetas bíblicos e, portanto, como um evento de caráter messiânico.

\footnotetext{
${ }^{327}$ Ravitzky, 2001, pg. 87.

328 A passividade política pregada pela ortodoxia anti-sionista é tal que seus membros nunca se envolveram em nenhuma atividade conspiratória contra o Estado de Israel.

$\mathrm{O}$ fato de integrantes do Naturei Karta serem vistos com frequência em manifestações políticas contra $\mathrm{o}$ Estado de Israel e de apoio a palestinos e iranianos nao deve ser entendido como ruptura desta passividade política, afirmam. Mas sim como a clássica estratégia de sobrevivência judaica, que através dos séculos de exílio sempre procurou estabelecer laços com a força política dominante. Na avaliação dos Naturei Karta, os muçulmanos certamente dominarão o Estado sionista no futuro e, portanto, convém garantir proteção para a comunidade judaica.

(Ravitzky, 2001, pgs. 107 e 108)

329 Tshuvah (תשובה) - do verbo hebraico "voltar". "Arrependimento, penitência". Conceito religioso judaico de estímulo ao retorno à observância para aqueles que deixaram o estilo-de-vida tradicional. Para os rabinos, mesmo um judeu religioso pode fazer tshuvah, aprimorando sua observância dos preceitos.

${ }^{330}$ Ravitzky, 2001, pgs. 111 e 112.

${ }^{331}$ Como contrapartida aos Três Juramentos, a ala ortodoxa sionista buscou no Talmud da Babilônia uma justificativa para seu apoio ao sionismo. Encontraram-na na seguinte passagem do Tratado Sanedrin 98a, onde interpreta-se um versículo de Isaías:

“"Eu, o Senhor, a seu tempo farei isso prontamente' (Is 60:22). Está escrito "a seu tempo" e ao mesmo tempo está escrito "prontamente”. Se forem merecedores, será prontamente; do contrário, será a seu tempo".

Esta passagem faz parte de uma longa discussão entre os rabinos talmúdicos sobre a redenção e a vinda do messias. Aqui, afirma-se que, se o povo judeu tiver bom comportamento, a redenção messiânica acontecerá antes do tempo pré-estabelecido por Deus ("prontamente"). Mas se não merecerem, a redenção somente ocorrerá na época pré-determinada ("a seu tempo"). Para os ortodoxos sionistas, os judeus não são merecedores da redenção, mas chegou o momento pré-estabelecido.
}

(Ravitzky, 2001, pgs. 180 e 181) 
"O Estado de Israel é a base do trono de Deus no mundo" ( מדינת ישראל, יסוד (כסא ה' בעולם , proclamou o "pai" da ortodoxia sionista, o rabino Avraham Itzhak Hacohen Kook (1865-1935), conhecido como Rav Kook ${ }^{332}$. Nascido na Europa Oriental (atual Letônia), imigrou para a Palestina em 1904, onde tornou-se o primeiro rabino-chefe da comunidade judaica local. Faleceu antes da fundação do Estado judeu e do Holocausto.

Kook justificou seu apoio aos sionistas seculares considerando-os indivíduos que promoviam de forma inconsciente a redenção, ao construírem as bases materiais necessárias ao processo messiânico ${ }^{333}$. Comparou-os ${ }^{334}$ aos trabalhadores estrangeiros que construíram o Templo para o rei Salomão (1Reis 5) sem saber da verdadeira função religiosa do santuário. Mas a redenção final e completa, na concepção de Kook, somente acontecerá numa etapa posterior, no futuro, quando os sionistas reconhecerem o significado religioso de suas atividades.

A visão do Rav Kook ganhou 335 novo ímpeto com os acontecimentos históricos que se seguiram à sua morte: o Holocausto e a criação do Estado de Israel. Os ortodoxos sionistas, que até então representavam uma ala marginalizada no interior do judaísmo, receberam forte adesão de outros ortodoxos. Seu filho, o rabino Zvi Yehuda Hacohen Kook (1891-1981) continuou a linha paterna e levou-a até seus limites. Em 30 anos de atuação, formou toda uma geração de seguidores, influenciou a formação do grupo político-religioso Gush Emunim ("Bloco dos Fiéis") e, assim,

\footnotetext{
Outro conceito judaico utilizado por estes ortodoxos para justificar o apoio ao Estado de Israel diz respeito ao processo messiânico. O judaísmo traz dentro de si diferentes visões sobre este processo e a ala ortodoxa sionista esposou uma delas, segundo a qual não há necessidade de um messias na etapa inicial do processo. A redenção acontecerá em etapas, afirmam, culminando no aparecimento desta personalidade histórica (messias) apenas num estágio posterior, após uma série de fases vencidas, para fechar o processo.

Já outros segmentos do judaísmo esposam visões diferentes, como por exemplo os hassídicos de linha Lubavitch, que entendem a época messiânica como estreitamente vinculada ao aparecimento do indivíduo messias (Ravitzky, 2001, pgs. 113 e 144).

${ }_{332}$ Ravitzky, 2001, pgs. 115 e 136.

${ }^{333}$ Ravitzky, 2001, pgs. 141, 154 e 158.

${ }^{334}$ Kook também comparou-os ao rei Ciro da Pérsia, que ao decretar o fim do exílio babilônico e permitir aos judeus reconstruírem o Templo de Jerusalém (Esdras 1), participou inconscientemente do plano divino.

(Ravitzky, 2001, pg. 155)

${ }^{335}$ Ravitzky, 2001, pgs. 112, 120, 171, 185 e 193 / Michman, 2005, pg. 268.
} 
incentivou o movimento de colonização judaica na Cisjordânia e Gaza ${ }^{336}$. Seus discípulos tornaram-se rabinos e líderes espirituais de várias destas colônias e alguns chegaram a extremismos, como a formação de um movimento ilegal que planejou explodir a mesquita da Cúpula Dourada localizada no Monte do Templo, em Jerusalém.

Para Zvi Yehuda, os Três Juramentos talmúdicos que proibiam a imigração em massa à Terra de Israel foram abolidos por decreto divino. Ele afirmou: "Não somos nós, de carne-e-osso, que agimos para forçar o Final dos Tempos (דחיקת הקץ), mas sim o Dono da Casa, o Senhor do Mundo, que está nos forçando; não é a voz de uma pessoa de carne-e-osso, mas sim a voz do Deus Vivo que destruiu o muro que deixou de nos separar de nossa terra, convocando-nos: 'Subam,",337.

Segundo o rabino, já não se trata mais de discutir se o Estado de Israel representa ou não o início da redenção. Numa declaração feita após a Guerra do Yom Kipur (1973), o rabino afirmou que a humanidade já se encontrava no interior do processo messiânico: "Há pessoas que falam que vivemos o início da redenção (...) mas temos que ver com olhos abertos que já estamos no meio da redenção (...) O início foi há mais de cem anos, quando recomeçou o assentamento judaico na Terra de Israel" ${ }^{\prime 338}$.

Na concepção de Zvi Yehuda, o Estado de Israel, como elemento fundamental do processo de redenção, ganha contornos extraordinários. "O Estado (de Israel) é todo santo, sem nenhum defeito. O valor deste Estado não está condicionado à quantidade de observantes dos mandamentos que vivem em seu interior. Claro, a aspiração é que todo o povo se ligue à Torá e aos mandamentos, mas este Estado é sagrado de qualquer maneira" 339 .

\footnotetext{
${ }^{336}$ A teologia de Zvi Kook levou-o a se posicionar contra qualquer concessão territorial aos vizinhos árabes. Para o rabino, sua posição política era reflexo do desejo de Deus. "O Todo-Poderoso tem uma política própria. E, de acordo com ela, processa-se a política aqui de baixo. Parte da redenção é a conquista da terra e o assentamento nela. Esta é a determinação da política divina, que nenhuma política aqui de baixo pode contrariá-la". E adicionou: "O Estado de Israel é um assunto divino (...) não apenas não se deve fazer retirada de nenhum quilómetro da Terra de Israel, como vale o contrário, devemos acumular conquistas e libertações (de terra)" (Ravitzky, 2001, pgs 182 e 183).

${ }^{337}$ Ravitzky, 2001, pgs. 111 e 112.

${ }^{338}$ Ravitzky, 2001, pgs. 111.

${ }^{339}$ Ravitzky, 2001, pgs. 189.
} 
No interior da ortodoxia sionista, há uma outra linha de pensamento, que também deve ser citada. Trata-se do Mizrachi ${ }^{340}$, facção religiosa fundada pelo rabino Itzhak Yacov Reines (1839-1915), que participou do Primeiro Congresso Sionista (1897) e foi um dos primeiros líderes ortodoxos a colaborar com Herzl ${ }^{341}$. Reines e seus seguidores concederam valor religioso ao sionismo, mas ao contrário de Kook, recusaram conceder contornos messiânicos a este movimento político.

Para os adeptos do Mizrachi ${ }^{342}$, os sionistas, ao procurarem uma solução para o anti-semitismo e a perseguição contra os judeus, estavam cumprindo o mandamento judaico de "salvamento de vidas". Também afirmavam que o sionismo, apesar de seu caráter secular, acabaria produzindo um lugar propício ao retorno à religião de parte significativa do povo judeu que, na Europa da época, vivia um rápido processo de assimilação.

Porém, o Mizrachi também frisava ${ }^{343}$ que a criação do Estado de Israel não era um sinal da aproximação dos Últimos Dias. O sionismo, ainda que legítimo, não estava ligado ao ideal messiânico e destinava-se unicamente a melhorar a situação imediata da vida dos judeus.

Para enfatizar sua visão não-messiânica do sionismo, Reines apoiou a proposta - posteriormente derrotada - de Herzl, em 1903, de fundar o Estado judeu em Uganda (África). Com isto, o rabino quis sublinhar a diferença entre a busca de um refúgio para judeus perseguidos e a idéia religiosa de redenção na Terra Prometida ${ }^{344}$.

\footnotetext{
${ }^{340}$ A sigla da facção, "Mizrachi", significa em hebraico tanto "oriental" quanto a abreviatura de "centro espiritual" (מרכז רוחני). O Mizrachi teve um grande impacto na vida israelense. A Universidade BarIlan, fundada pelo movimento, tornou-se um importante centro de pesquisa no país. Seu movimento juvenil, Bnei Akiva, atrai parte significativa da população ortodoxa. Sua influência chegou até a fundação de bancos, como o Bank Ha-Mizrachi (Encyclopaedia Judaica, $1^{\text {a }}$ edição, verbete "Mizrachi", Vol. 12, pgs. 175 a 180).

${ }^{341}$ Encyclopaedia Judaica, $1^{a}$ edição, verbete "Reines", Vol. 14, pgs. 58 e 59.

${ }^{342}$ Ravitzky, 2001, pg. 54. / Sacks, 1993, pgs. 67 e 68.

${ }^{343}$ Ravitzky, 2001, pg. 54.

${ }^{344}$ Sacks, 1993, pgs. 67 e 68.
} 
Quanto a colaborar com os sionistas seculares ${ }^{345}$, o Mizrachi limitava-se a cooperar em assuntos práticos e na proteção à comunidade judaica na Terra de Israel. Quanto a assuntos religiosos, a orientação da facção para seus membros era evitar contato. Como explicou o rabino Samuel Mohilewer, do Mizrachi: "Nossa atitude para com aqueles entre nós que não observam os preceitos religiosos deve ser como se um incêndio tivesse começado em nossa casas, colocando em perigo nossos familiares e propriedades. Nestas circunstâncias, não receberíamos contentes e com amor a ajuda daqueles que vieram nos resgatar, mesmo sendo eles irreligiosos a nossos olhos?" 346.

\section{3 - Maioria ortodoxa}

Atualmente, a maior parte da ortodoxia em Israel rejeita tanto o sionismo religioso quanto o anti-sionismo religioso. Para esta maioria, o Estado de Israel é um fenômeno neutro do ponto-de-vista religioso: nem santo, nem impuro; não faz parte do processo messiânico, mas também não é anti-messias ${ }^{347}$.

Esta maioria congrega os mais diferentes grupos e linhas ortodoxas (hassidim $^{348}$, litaim ${ }^{349}$, ashkenazim, sefaradim), mas a característica comum é considerar que o povo judeu continua vivendo em exílio, mesmo após a fundação do Estado de Israel ${ }^{350}$. Entendem o exílio como uma situação existencial pré-redenção,

\footnotetext{
${ }^{345}$ Ravitzky, 2001, pg. 55.

${ }^{346}$ Sacks, 1993, pg. 68.

${ }^{347}$ Ravitzky, 2001, pg. 201.

348 Hassidismo (חסידות) - da palavra hebraica hesed, "benevolência, graça, bom tratamento". Movimento judaico religioso de caráter popular, surgido na Europa Oriental, na segunda metade do século XVIII. Reagindo ao que consideravam excessivo intelectualismo do establishment judaico, os rabinos hassidim propuseram maior entusiasmo e emocionalismo na vivência religiosa. Outra característica do movimento é a liderança rabínica carismática.

${ }^{349}$ Litaim (ליטאים) - "lituanos". Cultura judaica que floresceu a partir da Lituânia, onde viviam 1,5 milhão de judeus no final do século XIX, e que continua influente até hoje. Moldados pelo rabino Eliyahu ben Shlomo Zalman, o Gaon de Vilna (1720-1797), os litaim vivenciam o judaísmo ao redor de suas yeshivot, caracterizadas pelo estudo talmúdico rigoroso. No passado, lideraram a oposição contra o hassidismo, daí também terem sido denominados mitnagdim (“oponentes").

${ }^{350}$ Como afirmou um dos inspiradores desta maioria, o rabino Menachem Mendel Schneerson (19021994), da linha ortodoxa hassídica Lubavitch e um dos mais importantes líderes religiosos da segunda metade do século XX: "A época em que vivemos não é o início da redenção (אתחלתא דגאולה) e a imigração de muitos judeus para a Terra Santa não é a Reunião dos Exilados (קיבוץ גלויות), mas sim a possibilidade de salvar judeus numa época de exílio".

Outro integrante desta maioria, o rabino ortodoxo Eliezer Menachem Schach (1896-2001), de linha litai e grande opositor de Schneerson em outras áreas, concordou com esta avaliação: "O povo de Israel
} 
na qual se vivencia uma espiritualidade decaída e imperfeita, que apenas se modificará com a chegada da era messiânica ${ }^{351}$.

A consolidação desta maioria no interior da ortodoxia deu-se sob o impacto do Holocausto e da criação do Estado de Israel. De opositores ferrenhos do sionismo em seu início, tornaram-se simpáticos à idéia de um lar nacional judaico após a destruição nazista. Também a declaração de independência do país, em 1948, colocou-os frente a uma situação prática e concreta, não mais uma discussão teórica sobre a validade do sionismo $^{352}$.

Esta maioria afirma que o Estado de Israel deve ser avaliado como qualquer outro país do mundo, ou seja, por sua contribuição ao judaísmo ortodoxo. Se este Estado garantir a segurança dos judeus e um ambiente propício ao funcionamento das instituições religiosas, receberá uma valoração positiva; caso contrário, será denunciado ${ }^{353}$.

A maioria ortodoxa diferencia a base ideológica do Estado de Israel - o sionismo secular, que consideram condenável - de seus mecanismos institucionais, como partidos políticos e estruturas governamentais, com os quais permitem-se interagir ${ }^{354}$. Afinal, ponderam, por que deveriam se comportar no Estado de Israel de maneira diferente como se comportam em outros países do mundo? Como justificou o rabino ortodoxo Meir Karelitz, integrante desta maioria: “Em todo país estrangeiro, procuramos um lobista que atue em favor do judaísmo ortodoxo no interior do governo; portanto se houver a possibilidade de colocarmos no interior do governo israelense um lobista que proteja os assuntos do judaísmo da Torá, devemos fazer isto sem hesitação" 355 .

está em exílio até a vinda do salvador, mesmo num tempo em que ele (povo judeu) está na Terra de Israel. E isto não é redenção nem início da redenção (אתחלתא דגאולה)".

(Ravitzky, 2001, pg. 204)

${ }^{351}$ Ravitzky, 2001, pgs. 203 e 206.

${ }^{352}$ Ravitzky, 2001, pg. 206.

${ }^{353}$ Ravitzky, 2001, pgs. 201, 210 e 211.

${ }^{354}$ Ravitzky, 2001, pgs. 209 e 215.

${ }^{355}$ Ravitzky, 2001, pg. 216. 
O rabino Yizhak Meir Levin (1894-1971), líder do Agudat Israel ${ }^{356}$ e integrante desta maioria, defendeu a participação ortodoxa na política israelense ao descrever como seria a vida cotidiana no país sem a participação dos religiosos no governo: os trens funcionariam no shabat, os açougues ofereceriam abertamente carne não-kasher, os estudantes de yeshivot seriam alistados no exército e o sistema educacional ortodoxo independente seria prejudicado ${ }^{357}$.

Nas últimas décadas, rabinos importantes desta maioria ortodoxa fizeram declarações públicas que, à primeira vista, poderiam ser interpretadas como prósionistas. O rabino Yisrael Meir Kagan, chamado de Hafetz Haim, interpretou a Declaração Balfour ${ }^{358}$ como um sinal do “despertar de Cima” (isto é, de redenção) e o rabino Yehuda Leib Tsirelson, considerou a Comissão Peel ${ }^{359}$ como um sinal da "Providência divina". Já o rabino Menachem Mendel Schneerson afirmou, após a vitória militar israelense na Guerra dos Seis Dias (1967), que o crédito (זכות) junto a Deus alcançado pelos soldados foi maior que o obtido pelos religiosos que se dedicaram ao estudo da Torá naquele momento ${ }^{360}$.

\footnotetext{
${ }^{356}$ O movimento religioso-político Agudat Israel (em português, "Associação Israel") foi fundado em 1912 por ortodoxos ashkenazim desgostosos com a Reforma e o sionismo. Sua plataforma era a preservação da ortodoxia e a afirmação da halakhah como princípio governador da sociedade judaica. Até o Holocausto, o Agudat Israel adotou uma posição radicalmente anti-sionista, argumentando ser contra a criação de um Estado secular na Terra de Israel. Com forte atuação na Polônia pré-Segunda Guerra Mundial, chegou a eleger representantes para o Parlamento local. Após a destruição nazista, o movimento tornou-se mais aberto à idéia de um Estado para os judeus na Palestina. Em 1947, o movimento recebeu garantias da liderança sionista de que o futuro governo israelense manteria o status quo de respeito à vida religiosa e, como consequência, um ano mais tarde, o Agudat Israel participou da declaração de independência.

Transformado em partido político, elegeu representantes em todos os parlamentos da história israelense. Concentrou esforços para garantir um sistema educacional ortodoxo independente e evitar que mulheres religiosas fossem alistadas no exército. De modo geral, caracteriza-se por defender a observação da halakhah na vida pública do país.

O partido não segue uma linha política rígida em assuntos como segurança e política exterior, preferindo adotar posições pragmáticas, com ênfase na obtenção de privilégios para a comunidade ortodoxa. Porém, desde a década de 90 , suas posições têm se aproximado da direita política.

(Encycopaedia Judaica, verbete "Agudat Israel”, pgs. 421 a 426; site do Parlamento de Israel (Knesset): http://www.knesset.gov.il/faction/eng/FactionPage_eng.asp?PG=22)

${ }^{357}$ Ravitzky, 2001, pgs. 225 e 226.

${ }^{358}$ A chamada Declaração Balfour foi feita em 2/11/1917 pelo secretário das Relações Exteriores britânico, Arthur James Balfour, em carta ao Barão Lionel W. Rothschild, líder da comunidade judaica inglesa. Na declaração, o governo britânico afirmou apoiar o "estabelecimento de um lar nacional para o povo judeu na Palestina".

${ }^{359}$ Comissão nomeada em 1936 pelo governo britânico, então governante da Palestina, para propôr uma solução para o conflito judeu-árabe. Liderada por Robert Peel, a comissão propôs a divisão do território em três partes: um Estado judeu, um Estado árabe e uma área neutra que englobasse lugares sagrados.

${ }_{360}^{36}$ Ravitzky, 2001, pgs. 220, 221, 239 e 240.
} 
Porém, declarações como estas não devem ser entendidas como um distanciamento da visão tradicional desta maioria ortodoxa. Para este grupo, os eventos políticos do último século podem ser vistos como sinais de intervenção divina e até mesmo uma janela de oportunidade para a tão-esperada redenção. Porém, segundo eles, o fato do processo político ter sido liderado por uma ideologia como o sionismo, descomprometida com a religião, "estragou" o potencial deste momento messiânico $^{361}$.

\footnotetext{
${ }^{361}$ Ravitzky, 2001, pgs. 218, 220 e 221.

Neste sentido, pode-se compreender o comentário do rabino Schneerson a respeito da Declaração de Independência do Estado de Israel: "[Deus], fonte do bem e da benevolência, dono dos milagres e maravilhas e que faz mudanças radicais, foi Ele quem determinou (...) as causas que levaram aos milagres e à grande salvação de milhões (sic) de judeus na Terra de Israel. Pois, realmente, aquele era o tempo qualificado e determinado de Cima (...). Após [Deus] ter visto o Seu povo de Israel (...) (alvo de) decretos terríveis, deu a eles a oportunidade, no meio de uma época de exílio, para se organizarem de acordo com suas vontades, com instituições próprias. Através disso, centenas de milhares de judeus encontraram refúgio na Terra de Israel. Na realidade, se o povo de Israel (...) se comportasse corretamente, esta oportunidade teria sido maravilhosa para provar que (Israel) já é merecedor da redenção (...) (Porém seus líderes) decidiram viver como as demais nações, em assuntos internos e legislativos (...) e basearam sua existência (...) sobre bases que não tem nenhuma relação com a Torá de Israel (...) e assim, infelizmente, novamente o povo de Israel não conseguiu sobrepujar-se, aproveitar a oportunidade e mostrar que a redenção poderia se revelar" (Ravitzky, 2001, pg. 219).
} 


\section{9 - A SINGULARIDADE DO HOLOCAUSTO}

A Shoá pode ser equiparada a outras destruições da história judaica?

O Holocausto não foi a primeira vez que pensadores judeus tiveram a sensação de que jamais houve um evento de tal magnitude em toda a História. Os contemporâneos da destruição do Primeiro Templo de Jerusalém também ficaram estupefatos com a violência e confundidos com o desafio trazido aos dogmas tradicionais. $\mathrm{Na}$ época, já se perguntava se houvera no passado um acontecimento de tal malignidade ${ }^{362}$.

No pós-Holocausto, os pensadores judeus se dividiram ao opinar sobre a singularidade ${ }^{363}$ do genocídio nazista, ou seja, se este foi ou não um acontecimento único na História ${ }^{364}$. Um primeiro grupo considerou a Shoá como um evento incomparável, enfatizando a surpreendente crueldade com que foi perpetrado, a inédita organização industrial da matança, o espantoso envolvimento de civis colaboracionistas nas carnificinas e o fato da barbárie ter sido perpetrada por um dos povos mais civilizados do mundo.

Já um segundo grupo de pensadores permitiu-se equiparar a Shoá a outros massacres sofridos pelo povo judeu durante sua história. Eles reconhecem elementos inéditos em termos de crueldade e número de vítimas no episódio, porém afirmam que, do ponto-de-vista da especulação religiosa, o genocídio nazista não apresentou um desafio diferente de catástrofes anteriores. Em seu argumento mais pungente, afirmam que conciliar uma divindade justa, boa e interessada nos assuntos humanos com o assassinato de milhões de inocentes apresenta a mesma dificuldade que explicar a morte de uma só criança inocente.

Como escreveu Immanuel Jakobovits, um dos pensadores deste segundo grupo, “a dor infinita não pode ser aumentada por multiplicação. A morte repentina de

\footnotetext{
${ }^{362}$ Ver capítulo "Três Elementos para Pensar a Contradição entre os Rabinos - A Importância da Literatura de Hurban".

363 a palavra usada pelos teólogos em inglês, uniqueness, parece-me intraduzível.

${ }^{364}$ Giuliani chama a atenção para outro aspecto bastante problemático em toda a discussão sobre a singularidade do Holocausto. Como ele bem aponta, todo evento histórico é singular e único, não equivalendo nunca exatamente a outro evento histórico (2002, pg. 6).
} 
um bebê, que coloca um jovem casal em luto, pode ser não menos confuso do pontode-vista teológico do que o genocídio deliberado de milhões. De fato, no caso do bebê, porque está totalmente além do controle humano, pode apresentar um confronto ainda mais direto com a inescrutabilidade divina" 365 .

A discussão sobre a singularidade do massacre nazista teve um impacto decisivo na Teologia do Holocausto. Vários pesquisadores acadêmicos ${ }^{366}$ optaram por classificar os pensadores religiosos da Shoá em dois grandes grupos: os que afirmam a singularidade do episódio e os que igualam-no a outras destruições do passado. Isto porque, afirmam os pesquisadores, a opinião sobre a singularidade determina a linha de pensamento destes autores.

Assim, os pensadores que defendem a singularidade do Holocausto recusam conceitos judaicos tradicionais de explicação e buscam idéias totalmente novas. Para eles, visões tradicionais são inadequadas para lidar com um evento de perversidade inédita. Daí ser comum proporem novos conceitos para entender a Shoá ${ }^{367}$, como é o caso da idéia de Aliança Voluntária, apresentada por Irving Greenberg.

Já o segundo grupo, formado por pensadores que equiparam o Holocausto a outras catástrofes judaicas do passado, permite-se utilizar os mesmos conceitos religiosos usados para explicar catástrofes em séculos passados. Dizem que para eventos similares, vale o mesmo instrumental teórico ${ }^{368}$. Exemplo desta atitude é a reflexão de Eliezer Berkovits sobre a Shoá.

O acadêmico Schweid, um dos que defendem a clasificação dos pensadores do Holocausto num destes dois grupos, resumiu a questão desta maneira: "Todo pensador religioso que se encontra compelido a tratar do desafio da teodicéia após o Holocausto necessita primeiramente decidir sobre sua posição quanto a estas questões preliminares: o Holocausto é único e sem precedentes do ponto-de-vista teológico? O

\footnotetext{
365 Jakobovits, 1988, pg. 176.

${ }^{366}$ Schweid, 1994, pg. 334 / Braiterman, 1998, pg. 13 / Morgan, 1992, pg. 96 / Gillman, 2002, pg. 109/ Sacks, 1993, pg. 49.

${ }^{367}$ Gillman, 2002, pg. 109 / Braiterman, 1998, pg. 13 / Schweid, 1994, pg. 334 / Leaman, 1995, pgs. 185,201 e 202.

${ }^{368}$ Gillman, 2002, pg. 109 / Schweid, 1994, pg. 334 / Leaman, 1995, pg. 185.
} 
Holocausto levanta obstáculos inteiramente novos para a fé na Divina Procedência ou estamos enfrentando apenas uma forma agravada dos mesmos velhos obstáculos?" ${ }^{\circledR 69}$.

Vale notar que não foram apenas os pensadores religiosos que se dividiram sobre a questão da singularidade do Holocausto. Também acadêmicos e historiadores opinaram sobre o assunto e podem ser divididos nos mesmos dois grupos vistos acima. Por exemplo, Schweid ${ }^{370}$ e Katz ${ }^{371}$ defenderam a singularidade do Holocausto. Já Braiterman ${ }^{372}$ e Leaman ${ }^{373}$ consideram que a Shoá não foi um evento único na História, apesar de sua crueldade e barbárie.

\footnotetext{
${ }^{369}$ Schweid, 1994, pg. 334.

${ }^{370}$ Schweid recusa a comparação entre o assassinato de uma criança inocente e a desumanização no massacre de milhões de pessoas pelos nazistas. Para ele, os campos-de-concentração e guetos apresentam um "problema único" (Schweid, 1994, pg. 360).

${ }^{371}$ Katz utiliza argumentos históricos para defender a singularidade do Holocausto. Segundo ele, a intenção nazista de destruir fisicamente todos os indivíduos identificados com o judaísmo, e não apenas sua identidade cultural, foi excepcional na história. Nisto, o Holocausto se diferencia de tragédias passadas que se abateram sobre os judeus, bem como de massacres contra outros povos, como a perseguição aos armênios na Primeira Guerra Mundial ou o extermínio de índios no Brasil colonial (Katz, 1983, pgs. 287 e.d.).

${ }^{372}$ Para Braiterman, na história judaica ocorreram outras catástrofes e assassinatos de proporções consideráveis e que levantaram os mesmos desafios à noção de uma divindade bondosa e poderosa (Braiterman, 1998, pg.13).

${ }^{373}$ Para Leaman, além dos judeus, também outros grupos étnicos sofreram massacres por razões políticas e econômicas, e não há razão para diminuir estes eventos como menos horríveis que o genocídio nazista (Leaman, 1995, pgs. 192, 193, 204 e 207).
} 


\section{5 - O HOLOCAUSTO NO PENSAMENTO DE JOSEPH SOLOVEITCHIK}

\section{$\underline{5.1 \text { - Biografia }}$}

Joseph Baer (Yosef Dov, em hebraico) Soloveitchik (1903-1993) ${ }^{374}$ foi o principal líder da Ortodoxia Moderna norte-americana durante a segunda metade do século XX. Na qualidade de diretor da Yeshiva University (Nova York), formou boa parte dos atuais rabinos desta corrente judaica nos EUA. Nasceu em Pruzhan, Polônia, numa das mais ilustres famílias de rabinos ortodoxos da Europa Oriental. Seu bisavô, Joseph Baer (1820-1892), co-dirigiu a célebre yeshiva Volozhin (na atual Belarússia), que serviu de modelo para todas as grandes yeshivot européias dos séculos 19 e 20. Seu avô, Haim Soloveitchik (1853-1918), criou um influente método de estudo do Talmud, denominado método Brisker ${ }^{375}$.

Joseph Soloveitchik foi introduzido nos estudos talmúdicos por seu pai, Moses, seu único professor até a juventude. Quando a família viveu em Varsóvia, em 1920, Joseph também iniciou estudos seculares, com tutores particulares. Aos 22 anos, deixou a casa paterna e ingressou na Faculdade de Filosofia da Universidade de Berlim, onde doutorou-se com tese sobre o filósofo Hermann Cohen ${ }^{376}$.

Em 1932, imigrou para os Estados Unidos e instalou-se em Boston, onde tornou-se rabino-chefe da pequena comunidade ortodoxa local e viveria até o final de sua vida. Até a Segunda Guerra Mundial, Soloveitchik foi membro do Agudat Israel, movimento ortodoxo anti-sionista. Mas sob o impacto do Holocausto, afastou-se desta posição tradicional de sua família e serviu como presidente-honorário da organização Mizrachi, também conhecida como "Sionistas Religiosos da América", durante quase meio século. Em 1935, durante sua única visita à Terra Santa, interessou-se em assumir a posição de rabino-chefe de Tel Aviv, mas não conseguiu a posição. Já na década de 50, recusou convite para se candidatar a rabino-chefe de Israel ${ }^{377}$.

\footnotetext{
${ }^{374}$ Sokol, 1995, pgs. 575 a 577 / Singer e Sokol, 1982, pg. 230 / Singer, 1993, pg. 327.

${ }^{375}$ Marcadamente cerebral e intelectual, no método Brisker o estudo dos textos sagrados recebe um valor religioso primordial e independente de outras práticas religiosas, como a oração e boas ações.

${ }^{376}$ Sokol, 1995, pg. 576 / Singer e Sokol, 1982, pg. 230.

${ }^{377}$ Rothkoff, 1972, pg. 132 / Rothkoff, 2007, pgs. 777 a 780 / Sokol, 1995, pgs. 576 e 578.
} 


\section{$\underline{5.2-\text { Obra }}$}

Soloveitchik teve um claro interesse pela cultura ocidental, e isto está exemplificado em seu ensaio The Halakhic Mind (A Mente Halákhica), de 1944. Nesta obra, que mais parece ter sido escrita por um acadêmico secular, Soloveitchik descreve o homem religioso como um ser basicamente racional. Em sua exposição, demonstra intimidade com a cultura ocidental ao citar uma grande variedade de filósofos e cientistas como Henri Bergson, Immanuel Kant, Karl Barth, Rudolf Otto, Niels Bohr, Max Planck, Albert Einstein, David Hume, entre outros ${ }^{378}$.

Esta e outras reflexões de Soloveitchik mostram seu desejo de pensar a halakhah a partir dos parâmetros da cultura ocidental. Em um outro ensaio, Halakhic Man (Homem Halákhico), cita Platão e Aristóteles no original grego e usa elementos da fisica teórica para definir o judaísmo halákhico em relação à ciência e a outras religiões.

O interesse pessoal de Soloveitchik pela cultura secular teve um forte impacto no judaísmo norte-americano. Vindo de uma autoridade como ele, serviu como validação para "virtualmente todos os judeus ortodoxos modernos" 379 também poderem adotar um estilo-de-vida que mesclasse tradição e elementos de modernidade. Na opinião de comentadores, não fosse esta validação de Soloveitchik, os ortodoxos modernos dos EUA carregariam um "sentimento de culpa extremamente pesado" ${ }^{380}$ por seu envolvimento com o mundo secular.

Mas Soloveitchik também foi bastante criterioso quanto à utilização da cultura ocidental. Ao mesmo tempo em que se interessou por Matemática, Ciência, Filosofia, Teologia Cristã e Literatura, não demonstrou interesse por historiografia moderna.

\footnotetext{
${ }^{378}$ Soloveitchik, 1986.

${ }^{379}$ Singer e Sokol, 1982, pg. 228.

${ }^{380}$ Singer e Sokol, 1982, pg. 228.
} 
Como consequência, sua abordagem do Talmud e da Bíblia Hebraica é conservadora. Quanto à moderna Crítica Bíblica, Soloveitchik considerava-a uma "heresia" ${ }^{381}$.

Segundo alguns estudiosos de sua obra, seu interesse pelo pensamento ocidental não o levou realmente a transformar-se num "ortodoxo moderno". Sob vários aspectos, ele permaneceu um ortodoxo da velha-guarda. Ao contrário de Maimônides no século XII e Samson Raphael Hirsch no século XIX, ele nunca declarou que outros judeus deveriam seguir seu exemplo e obter educação secular ${ }^{382}$.

Quanto à halakhah, Soloveitchik manteve-se durante toda sua vida um sólido defensor da tradição. Na qualidade de autoridade para assuntos legais judaicos, não determinou nenhuma diretiva nova ou arrojada, e não escreveu nada que o mostrasse suscetível a preocupações ou sensibilidades modernas. Neste sentido, Soloveitchik deve ser entendido com um ortodoxo clássico ${ }^{383}$.

É em sua reflexão não-halákhica que Soloveitchik apresenta sua face mais moderna ${ }^{384}$. Esta parte de sua obra foi considerada "audaciosa" 385 e seus ensaios, “inovadores, originais e ousados" ${ }^{386}$. Curiosamente, apesar de assuntos nãohalákhicos contar muito pouco no ambiente ortodoxo em que Soloveitchik foi criado, a maior parte do que publicou em vida é nesta área. Apenas recentemente, após sua morte, é que familiares e ex-estudantes começaram a publicar seu material halákhico, baseado em manuscritos, palestras e anotações de aulas ${ }^{387}$.

Porém, na esfera não-halákhica, Soloveitchik não foi um pensador sistemático, estando ausente em sua obra um sistema único e coerente. Seus diversos ensaios quase não se comunicam e certos temas centrais são abordados de maneira diversa em diferentes textos. Seus comentaristas têm considerável dificuldade em chegar à uma determinação clara de suas posições mais gerais ${ }^{388}$.

\footnotetext{
${ }^{381}$ Singer e Sokol, 1982, pg. 249.

${ }^{382}$ Sokol, 1995, pg. 578; Singer e Sokol, 1982, pgs. 228, 248, 249.

${ }^{383}$ Hartman, 2004, pg. 7.

${ }^{384}$ Singer, 1993, pg. 325

${ }^{385}$ Sacks, 1993, pg. 139

${ }^{386}$ Hartman, 2004, pg. 7

${ }^{387}$ Sokol, 1995, pg. 578 / Singer, 1993, pg. 325 / Singer e Sokol, 1982, pg. 231.

${ }^{388}$ Singer, 1993, pgs. 337 e 338 / Rothkoff, 2007, pgs. 777 a 780.
} 
Mas seja como autoridade de halakhah, seja como autor de reflexões em outras áreas do pensamento, Soloveitchik foi reconhecido como uma das maiores personalidades do judaísmo no século XX. Segundo David Hartman, sua "figura eleva-se acima de todos os outros pensadores judeus religiosos modernos" 389 . Para o professor Avi Sagi, da Universidade Bar-Ilan (Israel), “o rabino Soloveitchik é uma personalidade singular entre os gigantes espirituais do povo de Israel nas últimas gerações. Ele tinha uma rara combinação de homem da halakhah de uma capacidade analítica maravilhosa e de filósofo que dominava (...) o pensamento judaico e geral de seu tempo" ${ }^{390}$. Segundo Jonathan Sacks, escritor e rabino-chefe da Inglaterra, Soloveitchik foi "a personalidade de maior autoridade no pensamento ortodoxo pósguerra (..) Nenhuma outra figura da história da Ortodoxia Moderna rivalizou seu domínio, à la Maimônides, de duas culturas (judaica e ocidental)" 391.

\section{$\underline{5.3 \text { - O Holocausto no pensamento de Soloveitchik }}$}

$\underline{\text { Introdução }}$

Boa parte da reflexão de Soloveitchik sobre o Holocausto está concentrada em seu ensaio Kol Dodi Dofek (“A Voz do Meu Amado Bate à Porta”), transcrição de um sermão proferido na Yeshiva University, em abil de 1956, em homenagem ao Dia da Independência de Israel ${ }^{392}$. Nesta obra ${ }^{393}$, Soloveitchik baseia-se no livro bíblico “Cântico dos Cânticos" para refletir sobre a Shoá e o significado religioso do Estado de Israel. Ele utiliza especialmente o jogo-de-amor estabelecido entre os dois personagens centrais do livro bíblico e, em particular, o momento em que a jovem קול דודי דופק (Ct 5:2 e.d.).

\footnotetext{
${ }^{389}$ Hartman, 2004, pg. 5

${ }^{390}$ Sagui, 1996, pg. 11

${ }^{391}$ Sacks, 1993, pgs. 149 e 150

${ }^{392}$ Schwartz, "Harav Yosef...", pg 119 / Rothkoff, 2007, pgs. 777 a 780.

${ }^{393}$ Soloveitchik, 1976, pgs. 15 e.d.
} 
Neste ensaio, Soloveitchik afirma ${ }^{394}$ que a existência do sofrimento no mundo é uma realidade que não pode ser encoberta. É um fato que não tem como ser negado: há sofrimento no mundo. Mas mesmo com a existência do sofrimento, a avaliação bíblica da Criação como sendo algo "muito bom" é correta. Isto porque esta avaliação positiva é feita do ponto-de-vista ilimitado do Criador.

Já pelo entendimento parcial e finito do ser humano, o bem absoluto da Criação não pode ser apreendido e o mal permanece incompreensível. Apenas uma apreensão completa do mundo poderia permitir ao ser humano entender a questão do sofrimento. Mas como a compreensão humana é limitada, conseguimos vislumbrar apenas fragmentos isolados do "drama cósmico" e estamos impossibilitados de penetrar no mistério do mal ${ }^{395}$.

A resposta de Soloveitchik para a questão do sofrimento é que os atos de Deus são bons e nenhuma base de maldade se mistura na ordem das coisas e eventos. Tudo que existe é bom. Deve-se notar, ainda, que a existência não é um sistema monolítico, havendo níveis mais altos e mais baixos. Porém, mesmo o nível mais baixo de existência é bom. Portanto, o sofrimento é apenas uma ilusão, uma alucinação, cuja base é a comparação entre uma existência inferior com uma superior. Toma-se como mal uma situação que inclui em seu interior uma existência inferior ${ }^{396}$.

Soloveitchik cita Maimônides para afirmar que o mal não existe. O que existe é o bem inferior, que parece aos nossos olhos como mal. O mal, se visto de um pontode-vista geral, torna-se bem. Apenas quando isolamos um fenômeno e o examinamos separadamente é que este parece negativo. A morte, por exemplo, é uma experiência maléfica do ponto-de-vista da existência individual. Mas se analisamo-na do pontode-vista do propósito geral da humanidade, entende-se que o final do velho - o desaparecimento de pessoas que pertencem a um periodo histórico com mentalidade diferente - é uma grande benção. Em suma, nos limites da totalidade, o mal desaparece $^{397}$.

\footnotetext{
${ }^{394}$ Soloveitchik, 1976, pgs. 8 e 9.

395 Soloveitchik, 1976, pg. 8.

${ }^{396}$ Soloveitchik, Min HaSeara, pg. 110.

${ }^{397}$ Soloveitchik, Min HaSeara, pg. 110.
} 
Soloveitchik diferencia duas possíveis posturas do ser humano em relação ao sofrimento ${ }^{398}$. Na primeira, que ele deplora, o indivíduo faz perguntas teóricometafísicas sobre o mal. Neste caso, nunca obterá respostas, pois não há solução para este tipo de questão. Este indivíduo almeja uma visão harmonista do mundo, mas não a encontra. Aquele que busca uma solução para o problema do mal através do pensamento especulativo o faz em vão, pois nunca a encontrará. É impossível superar o mal através do pensamento filosófico-especulativo. A célebre questão "por que o justo sofre e o perverso prospera” é um enigma indecifrável.

Quando a curiosidade instintiva do homem o "ataca" ${ }^{399}$, propondo questões irrespondíveis sobre o mal, o melhor a fazer, segundo Soloveitchik, é se concentrar na fé no Criador e aceitar a situação. Se for bem-sucedido nesta operação, o indivíduo chegará à salvação completa.

Já a segunda postura em relação ao sofrimento, que Soloveitchik simpatiza ${ }^{400}$, o ser humano reconhece a realidade tal como ela é, e não deseja utilizar fórmulas hamonizadoras para esconder o mal. A abordagem da realidade deste homem é halákhica, sem qualquer tendência metafísica-especulativa. Quando este homem sofre, ele diz a si próprio: “O mal existe e não posso negá-lo; relaciono-me com o mal através da halakhah, como alguém que se interessa sobre o que deve fazer a respeito". Este homem não se interessa em buscar a razão ou o propósito do mal, mas sim uma postura prática em relação ao mal. Sua questão é: qual a obrigação do homem perante o mal?

O pensamento halákhico não medita ${ }^{401}$ sobre o mal do ponto-de-vista metafísico, mas sim moral-normativo. Não pergunta "o que" ou "por que", mas sim "para que". Não se interessa pelas razões, mas sim pelo aspecto do próposito do mal. A pergunta halákhica é: o que deve fazer o ser humano que se confronta com o sofrimento ? Como transformar o mal numa força construtiva?

\footnotetext{
${ }^{398}$ Soloveitchik, 1976, pgs. 7 a 9.

${ }^{399}$ Soloveitchik, 1976, pg. 14.

${ }^{400}$ Soloveitchik, 1976, pg. 9.

${ }^{401}$ Soloveitchik, 1979, pg. 144.
} 
Para Soloveitchik, o judaísmo não deseja que o ser humano faça uma racionalização do mal. Isto torna ainda mais pesado o coração humano. O judaísmo diz que o ser humano tem que se comportar como ser humano. Deve gritar, chorar, desesperar-se, entristecer-se e enlutar-se, como se pudesse modificar as leis cósmicas através destes sentimentos. No momento da dor e sofrimento, estes sentimentos são apropriados e respeitáveis. A dor leva ao suspiro, medo repentino e ao grito. O encontro com a morte precisa trazer expressões de protesto, queixa amarga, sentimento de confusão existencial e perplexidade completa. Deus deseja que o sofredor se comporte como um ser humano ${ }^{402}$.

Soloveitchik ${ }^{403}$ chega então a um ponto decisivo em sua reflexão, principalmente se temos o Holocausto em perspectiva: o sofrimento tem um elemento positivo, que é a purificação da alma humana. Ele escreve: “A resposta halákhica para esta questão é muito simples: o tormento acontece para elevar o ser humano, para purificar seu espírito e santificá-lo, limpar seu pensamento, refinar sua alma e ampliar os horizontes de sua vida. Ou seja, a função dos tormentos é corrigir o imperfeito na personalidade do homem (...) o sofredor precisa se erguer purificado e refinado, puro e limpo (...) De dentro do negativo cresce o positivo (...) o sofrimento obriga o ser humano a fazer tshuvah completa rumo a Deus".

Para o rabino, a resposta ideal à experiência de sofrimento é o arrependimento (tshuvah). No interior de seu sofrimento, o homem eleva-se e volta-se a Deus. Portanto, o judeu deve primeiro aceitar a sentença (דין) e só depois lutar contra o mal, conquistá-lo e elevá-lo ao nivel de bem ${ }^{404}$.

Pois, segundo Soloveitchik, é no momento de desespero e aflição que Deus se revela ao homem ${ }^{405}$. A divindade não se revela numa terra florida, mas sim no deserto amedrontador. Deus surpreende o homem ao se revelar num momento em que o ser humano já não esperava salvação, num momento em que estava sob o poder do destino cruel e sem esperança.

\footnotetext{
${ }^{402}$ Soloveitchik, Min HaSeara, pg. 51.

${ }^{403}$ Soloveitchik, 1976, pg. 10.

${ }^{404}$ Soloveitchik, 1979, pg. 144.

${ }^{405}$ Soloveitchik, 1979, pgs. 142 e 143.
} 
Segundo Soloveitchik, a idéia de que a revelação de Deus acontece na crise, na agonia e nas profundezas é um princípio do judaísmo. De dentro da aflição do ser humano que enfrenta o enigma obscuro do mal no mundo, Deus se revela ${ }^{406}$.

$1-\underline{\text { Jó }}$

Como vimos, na concepção de Soloveitchik, o sofrimento tem a capacidade de purificar o ser humano e aprimorá-lo. Para ele, o personagem bíblico Jó é um exemplo paradigmático de indivíduo que melhorou através do sofrimento ${ }^{407}$. O rabino recusa a leitura literal da Bíblia, onde Jó é apresentado como um indíviduo sem pecados ${ }^{408}$. Apoiando-se na literatura rabínica clássica ${ }^{409}$, Soloveitchik toma um outro rumo, afirmando que Jó era um pecador, uma pessoa não-benevolente que nunca se solidarizava com o sofrimento alheio. Até vivenciar a crise descrita na Bíblia, Jó nunca havia experimentado o sofrimento e, quando rezava ou oferecia sacrifícios a Deus, era apenas em seu próprio nome, numa postura egoísta.

Para Soloveitchik, Jó pré-crise representa a personalidade religiosa egoísta e rude $^{410}$. Ele não agia de forma maldosa, mas também não se comprometia com Deus. Seus atos religiosos tinham o único objetivo de manter o confortável status quo de sua família, conforme a passagem: "Seus filhos saíam para festins nas casas uns dos outros, cada um por sua vez, e convidavam suas três irmãs para comer e beber. Terminado um ciclo de tais festins, Jó os fazia vir, a fim de purificá-los. Levantava-se bem cedo e oferecia um holocausto para cada um deles, pois dizia a sei mesmo: 'Pode ser que meus filhos tenham pecado e maldito a Deus em seu coração'. Assim fazia Jó cada vez" (Jo 1:4 e 5).

Na visão do rabino, esta passagem mostra uma família fechada, egoísta e autocentrada. A existência comunitária era algo estranho para eles, que não sabiam o que era dar ou renunciar. Viviam dentro de suas fronteiras, distantes dos outros, isolados,

\footnotetext{
${ }^{406}$ Soloveitchik, 1979, pg. 144.

${ }^{407}$ Soloveitchik, 1976, pgs. 12 e 13.

408 Jo 1:1 : "homem íntegro e reto, que temia a Deus e se mantinha longe do mal".

${ }^{409}$ Braiterman, 1998, pg. 74.

${ }^{410}$ Soloveitchik, Min HaSeara, pg. 130.
} 
felizes e tranquilos com suas existências - vidas como a de um "Robison Crusoé" 411 , sem responsabilidade ou comprometimento.

Este estilo-de-vida continuou até que Satã golpeou Jó. A tragédia era inevitável, pois este tipo de existência acaba sempre em desastre. Mesmo quando os infortúnios descritos na Biblia o acometeram, a reação de Jó ficou limitada a propôr questões filosóficas sobre o mal. Neste nível, Deus teve que responder a ele, lembrando-o da ignorância humana sobre a Criação: "Onde estavas quando Eu fundei a terra? Dize-me isso, sabio que és" (Jo 38:4) ${ }^{412}$.

Mas após vivenciar um longo sofrimento, Jó ressurgiu modificado. "A grande maravilha acontece", escreve Soloveitchik ${ }^{413}$. Ele descobriu o coletivo e passou a viver uma existência direcionada para o bem comum. O final da narrativa bíblica mostra ${ }^{414}$ que o grande choque da punição inclemente revelou um novo Jó. No lugar da personalidade rude do passado, apareceu uma personalidade heróica. Apresenta-se uma nova pessoa, aberta, ligada aos demais seres humanos e vivenciando uma existência comunitária.

Para Soloveitchik, a reviravolta de Jó aconteceu através da prece, como mostra a passagem: "E o Senhor restabeleceu os negócios de Jó, enquanto ele orava por seu próximo; o Senhor elevou ao dobro todos os bens de Jó” (Jo 42:10). O Jó anterior, o homem bem-sucedido que não admitia fracassos, não entendia o significado da prece. A grandeza da oração, aponta o rabino, está em seu apelo à tranquilidade do homem, quando este reconhece as vicissitudes da vida ${ }^{415}$.

Os sacrifícios do Jó anterior não eram aceitos, suas preces não eram ouvidas e ele encontrou a catástrofe. A arte da prece verdadeira é levar a Deus a petição de muitos. Mas o egocêntrico, fechado em si mesmo, é inelegível para se juntar à comunidade de pactuantes na qual Deus tambem é membro. A divindade deseja que o ser humano saia de seu isolamento, mas Jó não entendia este simples postulado.

\footnotetext{
${ }^{411}$ Soloveitchik, Min HaSeara, pg. 130.

${ }^{412}$ Soloveitchik, 1976, pgs. 12 e 13 / Soloveitchik, Min HaSeara, pg. 130.

${ }^{413}$ Soloveitchik, 1976, pg. 13.

${ }^{414}$ Soloveitchik, Min HaSeara, pg. 131.

${ }^{415}$ Soloveitchik, Min HaSeara, pg. 131.
} 
Apenas após o sofrimento é que descobriu a grande experiência de participar de uma comunidade, de rezar em conjunto e por outras pessoas ${ }^{416}$.

\section{2 - Ocultamento da Face}

Soloveitchik diferenciou dois níveis de punição de Deus contra os seres humanos - Severidade do Julgamento (מידת הדין) e Ocultamento da Face (הסתר פנים) 417 .

A Severidade do Julgamento é uma punição divina diretamente proporcional ao pecado humano: se a transgressão foi pequena, o castigo será leve; se foi grave, a punição será rigorosa. Quando Deus atua de acordo com a Severidade do Julgamento, fica clara Sua presença e envolvimento nos assuntos humanos. A intenção divina é conduzir o homem ao arrependimento (tshuvah) e, neste caso, nunca está envolvida aniquilação total do pecador ${ }^{418}$.

Já o Ocultamento da Face é uma punição mais extrema. Nela, Deus suspende temporariamente Sua supervisão sobre o mundo, abandonando-o, como se não notasse o sofrimento humano. São aqueles eventos da história ou da vida do indivíduo em que parece que Deus abandonou completamente os assuntos terrenos, e o ser humano sente-se desertado e indefeso ${ }^{419}$.

Deve-se entender, aponta Soloveitchik, que o mundo somente existe porque compartilha a existência de Deus. Se Ele retirasse completamente Seu apoio ou Sua aprovação, o mundo instantaneamente voltaria ao Nada. O universo não é autosustentável, e sim contingente à existência de Deus. Portanto, um Ocultamento da Face total levaria ao fim do mundo. Daí, afirma o rabino, Deus nunca se retira totalmente de Sua criação, mesmo nestes momentos de extrema punição ${ }^{420}$.

\footnotetext{
${ }^{416}$ Soloveitchik, 1965, pgs. 60 e 61.

${ }^{417}$ Besdin, 1993, pg. 36.

${ }^{418}$ Besdin, 1993, pg. 36.

${ }^{419}$ Besdin, 1993, pgs. 31 e 35.

${ }^{420}$ Besdin, 1993, pg. 31 e 35.
} 
O Ocultamento da Face é "como se" Deus "desse as costas", deixando os eventos acontecerem ao acaso. Nesta situação, a usual vulnerabilidade do judeu é exacerbada e convida a uma situação de total extermínio. Como está escrito em Deuteronômio 31:17: "Minha cólera se inflamará contra eles (israelitas), Eu os abandonarei e esconderei minha face, para que sejam devorados" ${ }^{421}$.

Numa situação de Ocultamento da Face, os eventos se tornam incontroláveis e a magnitude das consequências, devastadoras. O Ocultamento da Face está relacionado à "perversidade" de Israel e pode ser considerado como sendo a punição final. É terrível, pois significa rejeição. Para o pensador, uma criança pode aguentar a punição de seu pai estoicamente, mas ser totalmente ignorada ou tratada como persona non grata em sua própria casa é uma "experiência amedrontadora" ${ }^{422}$.

O Ocultamento da Face pode ser explicado como uma reversão temporária do mundo ao seu estado pré-Criação, quando o caos prevalecia. É um período sem padrões físicos, um estado de caótica sub-existência. A lei moral divina torna-se inoperante e inaplicável nesta situação tão instável. Por outro lado, a Torá assegura que, com arrependimento (tshuvah), a vigilância divina característica da Criação pode ser restaurada ${ }^{423}$.

No ensaio Kol Dodi Dofek, Soloveitchik compara a atmosfera noturna do livro “Cântico dos Cânticos”, quando a jovem aguarda ansiosamente a vinda de seu amado, com a "asssustadora noite, cheia de horrores de Majdanek, Treblinka e Buchenwald (..) de cámaras-de-gás e crematórios (..) de absoluto ocultamento da face (grifo meu)" ${ }^{424}$. Nesta noite, reinaram "Satã e a destruição" 425.

O Holocausto foi Ocultamento da Face, escreve Soloveitchik ${ }^{426}$. Para o pensador, se não é possível explicar o Holocausto, pelo menos é possivel classificá-lo desta maneira, mesmo não havendo nenhuma resposta para a questão "por que". Os

\footnotetext{
${ }^{421}$ Besdin, 1993, pgs. 35 e 36.

${ }^{422}$ Besdin, 1993, pg. 36.

${ }^{423}$ Besdin, 1993,pg. 36.

${ }^{424}$ Soloveitchik, 1976, pg. 16.

${ }^{425}$ Soloveitchik, 1976, pg. 16

${ }^{426}$ Besdin, 1993, pg. 37.
} 
horrores ilimitados da Shoá representaram o caos anárquico de um estado préCriação.

\section{3 - Caráter Religioso do Estado de Israel}

Já a criação do Estado de Israel representou o retorno da Providência divina e o fim do Ocultamento da Face ${ }^{427}$. Retornemos ao ensaio Kol Dodi Dofek e à interpretação de Soloveitchik para o livro bíblico "Cântico dos Cânticos": "Eu dormia, mas meu coração velava; eis a voz do meu amado, que está batendo. Abreme, minha irmã, querida minha" (Ct 5:2). Para o rabino, as batidas do amado na porta da jovem de Jerusalém representam Deus (o amado) batendo subitamente à porta de sua querida (Israel), no meio da "assustadora noite", para encerrar Seu ocultamento ${ }^{428}$.

Soloveitchik interpretou as "batidas na porta" como seis grandes eventos históricos que cercaram a criação do Estado de Israel ${ }^{429}$. O primeiro foi a própria fundação do país, que ele classifica como "quase sobrenatural" ${ }^{430}$. Isto porque "talvez" 431 esta tenha sido a única vez em que a União Soviética se alinhou com os principais países ocidentais para apoiar uma proposta da Organização das Nações Unidas (ONU). "Minha tendência é acreditar que a ONU foi criada especialmente para este propósito (i.e., a fundação do Estado de Israel)", escreve ${ }^{432}$.

Soloveitchik enfatiza: "Não sei quem os jornalistas viram com seus olhos ocupando a presidência [da ONU] naquela crítica assembléia que decidiu pela fundação do Estado de Israel. Mas quem observou bem, com olhos espirituais, sentiu que o verdadeiro presidente, que venceu as discussões, foi o amado (Deus). Ele bateu com seu martelo sobre a mesa" ${ }^{433}$. A mesma ideia aparece em outro momento de sua

\footnotetext{
${ }^{427}$ Besdin, 1993, pg. 37.

${ }^{428}$ Soloveitchik, 1976, pgs. 16 e 20.

${ }^{429}$ Soloveitchik, 1976, pgs. 16 a 20.

${ }^{430}$ Soloveitchik, 1976, pg. 16.

${ }^{431}$ Soloveitchik, 1976, pg. 17.

${ }^{432}$ Soloveitchik, 1976, pg. 17.

${ }^{433}$ Soloveitchik, 1976, pg. 17.
} 
obra, onde escreve: "Falando claramente: o Todo-Poderoso criou o Estado de Israel ${ }^{434}$ (...) Foi a graça de Deus que tornou possível sua fundação" 435.

A segunda "batida na porta", continua o pensador, aconteceu no campo-debatalha, quando os soldados do diminuto exército israelense venceram a enorme força militar árabe, em 1948. "O milagre dos muitos-vencidos-pelos-poucos aconteceu perante nossos olhos", escreve ${ }^{436}$. Assim como Deus endurecera o coração do faraó do Egito na narrativa do Êxodo, também endureceu o coração dos árabes para que confrontassem militarmente o Estado judeu. "Se os árabes não houvessem declarado guerra contra Israel e tivessem concordado com o Plano de Partilha [da ONU], o Estado de Israel teria ficado sem Jerusalém, sem boa parte da Galiléia e sem partes do [deserto do] Negev" ${ }^{437}$.

A terceira "batida na porta" ${ }^{438}$, considerada por Soloveitchik como a mais forte de todas, foi no campo das idéias. Com a fundação do Estado de Israel, caiu por terra as afirmações anti-judaicas de que Deus teria retirado dos judeus o direito sobre a Terra Prometida.

A quarta "batida" foi o estancamento do processo de assimilação de judeus, que acontecia antes da criação do Estado de Israel. O estabelecimento do país e suas "conquistas heróicas" levaram indivíduos que antes haviam se afastado da cultura judaica a reatar seus laços com a tradição ${ }^{439}$. O Estado de Israel contribuiu para que judeus do mundo inteiro mantivessem sua auto-estima e identidade de "pequena ilha num mar tempestuoso de assimilação, ódio e decadência espiritual" 440.

A quinta "batida", considerada por Soloveitchik como "talvez a mais importante" 441 , foram os judeus começarem a reagir com força bruta frente à violência praticada contra eles. Pela primeira vez na história do exílio judaico, "a

\footnotetext{
${ }^{434}$ Soloveitchik, Hamesh Drashot, pg. 75.

${ }^{435}$ Soloveitchik, Hamesh Drashot, pg. 109.

${ }^{436}$ Soloveitchik, 1976, pg. 17.

${ }^{437}$ Soloveitchik, 1976, pg. 17.

${ }^{438}$ Soloveitchik, 1976, pgs. 17 e 18.

${ }^{439}$ Soloveitchik, 1976, pg. 18.

${ }^{440}$ Soloveitchik, Hamesh Drashot, pgs. 109.

${ }^{441}$ Soloveitchik, 1976, pg. 19.
} 
Providência surpreendeu os que nos odeiam com uma descoberta dramática: o sangue judeu tem valor" ${ }^{442}$. Para Soloveitchik, há situações em que o mandamento bíblico "olho por olho, dente por dente" deve ser observado literalmente. "A vingança sem objetivo é proibida, mas se for em defesa própria, é um direito elementar do homem",443.

Por fim, a sexta "batida" 444 foi a abertura dos "portões" da Terra de Israel e a possibilidade de judeus perseguidos encontrarem refúgio na "terra de seus antepassados".

Em outro momento de suas reflexões sobre o Estado de Israel, Soloveitchik diferenciou o sionismo religioso - que ele considera o ideal - do sionismo secular, que ele deplora, mas que foi o modelo implementado no país. O rabino afirma que entre estas duas visões de sionismo há uma "distância infinita". Ele escreve: "Não entendo o pensamento deles. Como é possível sequer imaginar a construção da Terra de Israel sem o Deus de Israel?" 445.

Soloveitchik pergunta-se se é possível os religiosos cooperarem com os sionistas seculares ${ }^{446}$. Ele responde baseando-se na história biblica do Sacrificio de Isaac: "Deus pôs Abraão à prova (...) 'Toma o teu filho, o teu único, Isaac, que amas. Parte para a terra de Moriá e lá o oferecerás em holocausto sobre uma das montanhas que eu te indicar'. Abraão levantou-se de manhã cedo, encilhou o jumento, tomou consigo dois de seus criados e seu filho Isaac (...). Partiu para o lugar que Deus lhe havia indicado. No terceiro dia, ergueu os olhos e viu de longe esse lugar. Abraão disse aos criados: 'Ficai aqui, vós, com o jumento. Eu e o jovem iremos lá adiante prosternar-nos e depois voltaremos a vós"” (Gn 22:1 a 5).

\footnotetext{
${ }^{442}$ Soloveitchik, 1976, pg. 19.

${ }^{443}$ Soloveitchik, 1976, pg. 19.

${ }^{444}$ Soloveitchik, 1976, pg. 20.

445 Soloveitchik, Hamesh Drashot, pg. 25.

${ }^{446}$ Soloveitchik, Hamesh Drashot, pg. 29.
} 
$\mathrm{Na}$ interpretação de Soloveitchik, Abraão e Isaac representam o sionismo religioso, enquanto os dois criados representam o sionismo secular. Os patriarcas e os serviçais caminham lado-a-lado durante parte da jornada, mas têm que se separar quando se aproximam do destino final. O rabino pergunta, retoricamente, por que Abraão (sionistas religiosos) convocou os criados (sionistas seculares) para participarem da jornada, se não desejava que chegassem juntos até o fim? Por uma razão prática: "O caminho é longo (...) repleto de cobras e escorpiões”. Abraão não teria conseguido cumprir o mandamento divino se não fosse o auxílio indispensável dos criados. Mas, ao se aproximarem do objetivo, o patriarca rompeu a parceria, com a esperança de que um dia "eles me compreendam completamente e então poderemos formar uma só fraternidade" 447.

Soloveitchik continua: "Para construirmos o Estado de Israel, nós (sionistas religiosos) marchamos lado-a-lado com todos os outros partidos, pois acreditamos que o Estado de Israel é o caminho que nos levará até o Monte Moriá. Também porque está claro para nós que, sozinhos, não conseguiremos trilhar este caminho (...) Mas quando o assunto é o Monte Moriá - leis religiosas, educação, observância do shabat, leis de kashrut, assuntos de rabinato (...) - apenas nós, os guardiões da tradição, sabemos como se aproximar do Monte Moriá, como se ajoelhar ao Todo-Poderoso, como construir o Templo sagrado" ${ }^{448}$.

Em sua reflexão sobre as diferenças entre o sionismo religioso e o sionismo secular, Soloveitchik diferencia ${ }^{449}$ dois tipos possíveis de existência coletiva: Aliança de Destino ${ }^{450}$ e Aliança de Missão ${ }^{451}$.

$\mathrm{Na}$ Aliança de Destino, a existência coletiva é uma situação forçada, e o indivíduo é pressionado a participar da existência nacional. Pode ser comparada a um "acampamento", onde os membros se reúnem pelo medo que sentem do mundo

\footnotetext{
${ }^{447}$ Soloveitchik, Hamesh Drashot, pgs. 29 a 31.

${ }^{448}$ Soloveitchik, Hamesh Drashot, pg. 32

${ }^{449}$ Soloveitchik, 1976, pgs. 22 e 23

ברית-גורל em hebraico, brit-goral ou

ברית-ייעוד em hebraico, brit-yeud ou
} 
exterior. No momento em que o indivíduo adere a este coletivo, surge em seu interior um sentimento de separação em relação ao restante do mundo. Por isso, a Aliança de Destino determinou a solidão histórica do povo judeu ${ }^{452}$.

Esta aliança, continua o pensador, foi formada ainda no Egito, antes do Êxodo comandado por Moisés. Todos os estratos da sociedade judaica - elite e pessoas simples, ricos e pobres, observantes e assimilados - ligaram-se num só destino. Esta aliança vale até hoje, não importando em que país os judeus vivam, nem que língua falem. Isto está refletido na halakhah, que afirma: “Todos os membros de Israel são fiadores entre si" ${ }^{453}$.

Já o outro tipo de existência coletiva, a Aliança de Missão, é caracterizado pelo fato do grupo decidir seu caminho por livre-escolha ${ }^{454}$. Esta existência foi iniciada no Monte Sinai, quando o povo judeu aceitou de livre-vontade os mandamentos de Deus, conforme afirma a Bíblia: "Moisés voltou, convocou os anciãos do povo e expôs-lhes todas estas palavras, tudo o que o Senhor lhe ordenara. O povo todo respondeu, unânime: 'Tudo o que o Senhor disse, nós o poremos em prática'. E Moisés referiu ao Senhor as palavras do povo" (Êxodo 19:7 a 8).

Este tipo de existência coletiva pode ser comparado a uma "comunidade" (em contraste com o "acampamento" da Aliança de Destino), em que os membros congregam-se motivados por amor ${ }^{455}$.

Na vida prática, escreve Soloveitchik, a Aliança de Destino e a Aliança de Missão estão integradas e é impossível separá-las. O judaísmo é, ao mesmo tempo, a consciência de uma existência isolada como grupo (Aliança de Destino) e a prontidão para a observância dos mandamentos religiosos (Aliança de Missão) ${ }^{456}$.

Para Soloveitchik, os sionistas seculares cometeram um erro básico de compreensão da existência judaica. Contrariando a Aliança de Destino, acreditaram

\footnotetext{
${ }^{452}$ Soloveitchik, 1976, pgs. 23, 24, 25, 29

${ }^{453}$ Soloveitchik, 1976, pgs. 23, 24, 25, 29

${ }^{454}$ Soloveitchik, 1976, pgs. 27, 29

${ }^{455}$ Soloveitchik, 1976, pgs. 27, 29

${ }^{456}$ Soloveitchik, 1976, pg. 30
} 
ser possível eliminar o particularismo do povo judeu, transformá-lo numa nação "como as demais" e, assim, acabar com a "solidão" do povo judeu. O sionismo secular esperava que o anti-semitismo terminasse após a criação do Estado de Israel, mas este intento falhou. "Pelo contrário, o anti-semitismo recrudesceu", avalia o rabino $^{457}$.

A solidão da existência judaica continua existindo na era pós-Estado de Israel, tal como sempre ocorreu no passado. "Talvez sua solidão seja até maior hoje do que no passado, pois atualmente (esta solidão) se revela claramente na arena (política) internacional" ${ }^{458}$.

A solidão judaica, afirma Soloveitchik, existe desde os tempos de Abraão. Quando o patriarca hebreu quis comprar uma caverna para enterrar sua esposa Sara, apresentou-se aos moradores locais dizendo: "Vivo convosco como estrangeiro e morador" (Gn 23:4). Para Soloveitchik, Abraão se sentia um "morador", ou seja, um concidadão que compartilhava o comércio e a língua de seus vizinhos. Porém, também se considerava um "estrangeiro", pertencente a um mundo diferente dos moradores locais 459 .

Da mesma maneira, o Estado de Israel é "morador" e "estrangeiro" entre as nações. É um país como os demais quando participa da ONU e de esforços científicos e culturais. Mas é também um "estrangeiro" entre as nações, alheio aos grandes blocos que reúnem países católicos, árabes ou negros. "Todo país tem um país-irmão; o único solitário, povo único na Terra, é o Estado de Israel" ${ }^{460}$.

Para Soloveitchik, o sionismo secular não conseguirá transformar a solidão do povo judeu ou sua particularidade, pois isto seria ir contra a Aliança de Destino ${ }^{461}$.

Lutar pela existência de um Estado "como os demais", mesmo que seja habitado por uma maioria de judeus, é um esforço em vão. "Se o Estado de Israel se

\footnotetext{
${ }^{457}$ Soloveitchik, 1976, pg. 35.

${ }^{458}$ Soloveitchik, 1976, pg. 35

${ }^{459}$ Soloveitchik, Hamesh Drashot, pg. 48

${ }^{460}$ Soloveitchik, Hamesh Drashot, pgs. 49 e 50

${ }^{461}$ Soloveitchik, 1976, pgs. 36 e 37
} 
transformar numa instituição secular, sem Torá, sem santidade, sem shabat, sem educação religiosa (...) o preço que pagamos em sangue e lágrimas será grande demais (...) $\mathrm{Na}$ qualidade de moradores, podemos viver bem no exílio (...) Um governo [apenas] em nome da soberania ou um Estado [apenas] em nome de um primeiroministro (...) não há nenhum valor nisso", escreve ${ }^{462}$.

O sionismo secular deveria abandonar seu caráter profano, transformar-se num "movimento religioso de retorno a Sião" e adotar a halakhah como sua Constituição, recomenda Soloveitchik. Desta maneira, o sionismo, agora religioso, levaria um simples "acampamento" de judeus no Oriente Medio a se transformar numa “comunidade" devota, combinando a Aliança de Destino com a Aliança de Missão ${ }^{463}$.

Uma última questão: Soloveitchik considerou a criação do Estado de Israel como um evento de caráter messiânico ou pelo menos como o início da redenção? O rabino não respondeu isto claramente em sua obra, mas, segundo a maior parte de seus comentaristas, a resposta é negativa.

Para Moshe Sokol, Soloveitchik não considerou a fundação do Estado de Israel em termos messiânicos, e sim apenas como uma oportunidade de crescimento espiritual e de auto-defesa para os judeus. "Não existe o mais leve sopro de messianismo no sionismo de Soloveitchik", afirma o comentarista ${ }^{464}$. Desta maneira, ele teria divergido agudamente de ortodoxos sionistas como Abraham Isaac Kook e seus seguidores ${ }^{465}$.

Dov Schwartz defende a mesma visão: a concepção de sionismo de Soloveitchik coincide com a do rabino Itzhak Yacov Reines, ou seja, é uma reação contra o anti-semitismo - e nisto reside sua importância religiosa. $\mathrm{O}$ estabelecimento

\footnotetext{
${ }^{462}$ Soloveitchik, Hamesh Drashot, pg. 52.

${ }^{463}$ Soloveitchik, 1976, pgs. 36 e 37.

${ }^{464}$ Singer e Sokol, 1982, pg. 253.

${ }^{465}$ Sokol, 1995, pg. 584.
} 
do Estado de Israel não tem ligação direta com a redenção e não é uma etapa do processo messiânico, apesar de ter sido um evento supervisionado por Deus ${ }^{466}$.

Lawrence Kaplan segue a mesma linha e também afirma que Soloveitchik não concedeu valor messiânico ao Estado de Israel. O pensador teria apenas concedido valor halákhico, por considerar o país um instrumento para o cumprimento de mitzvot $^{467}$. Kaplan nota que outros comentaristas não concordam nem com esta avaliação e julgam que Soloveitchik concedeu ao Estado judeu um valor apenas pragmático, como um lugar de refúgio para judeus perseguidos ou como barreira contra a assimilação ${ }^{468}$.

Também Jonathan Sacks ${ }^{469}$ faz uma avaliação sóbria sobre o significado religioso do sionismo na obra de Soloveitchik. Para Sacks, o rabino pensava que o messianismo do Estado de Israel dependeria da reação prática dos judeus frente ao chamado de Deus ("batidas na porta”) após o Holocausto. Mas como o país continuava se guiando pelo secularismo, seu caráter religioso não deveria ser superestimado.

David Hartman é uma das únicas vozes que apontam na direção contrária. Segundo ele, Soloveitchik concedeu valor messiânico ao Estado de Israel. "Para Soloveitchik, a reentrada do povo judeu na história mundial, mesmo que na forma de um Estado moderno e supostamente secular, é realmente o início da redenção, pois não se pode considerar a história judaica a sério sem reconhecer o papel redentor [do Estado] de Israel" ${ }^{470}$.

\footnotetext{
${ }^{466}$ Schwartz, "Mishnato shel Harav...", pgs. 129 e 130.

Para Schwartz, a hostilidade à religião demonstrada pela liderança política do Estado de Israel teria levado Soloveitchik a recusar considerar o país como parte do processo messiânico. Soloveitchik também teria levado em consideração que algumas das caracteríticas da era messiânica - o fim do ódio aos judeus e o início de uma existência harmônica com os demais povos - não se seguiram à declaração de independência do Estado de Israel.

${ }^{467}$ Mitzvah (מצוה) - do verbo hebraico "comandar, ordenar". Mandamento, preceito ou dever religioso de origem bíblica ou rabínica. O termo também é utilizado para denominar uma boa ação.

${ }^{468}$ Kaplan, 1999, pgs. 290, 296, 300, 301 e 303.

${ }^{469}$ Sacks, 1993, pgs. 72 e 73.

${ }^{470}$ Hartman, 1989, pg. 19.
} 


\section{4 - Por Causa de Nossos Pecados}

Soloveitchik não afirmou abertamente que o Holocausto foi punição divina por pecados cometidos pelo povo judeu. Mas ele parece expressar isto de forma indireta. Vimos que, para o pensador, o Ocultamento da Face é a mais severa das punições divinas contra seres humanos ${ }^{471}$.

Como Soloveitchik também afirma que o Holocausto foi Ocultamento da Face, pode-se concluir que o Holocausto foi uma punição por pecados do povo judeu. $\mathrm{O}$ rabino, porém, não identificou o exato pecado que levou à tamanha punição. "Não temos nenhuma resposta para a questão 'por que", escreveu ${ }^{472}$.

\section{5 - Aliança}

Para Soloveitchik, o fato do povo judeu ter sido assassinado em massa pelos nazistas não modificou em nada seu status de Povo Eleito. A idéia de Eleição de Israel $^{473}$ está no centro da fé judaica, portanto negá-la seria contradizer todo o judaísmo, afirma o rabino. Mas o que significa ser "eleito"? Soloveitchik responde a partir do termo usado pela Bíblia Hebraica para definir o status dos judeus - sgulah (סגולה) -, um termo traduzido tradicionalmente como "tesouro amado" 474 ("Se ouvirdes a Minha voz e guardardes a Minha aliança, sereis Meu tesouro amado (סגולה) entre todos os povos" - Ex 19:5).

Soloveitchik expõe seu entendimento de sgulah exemplificando com a situação de um indivíduo que aprecia vários objetos, mas ama especialmente um deles, mesmo que tenha dificuldade em explicar sua preferência. Outro exemplo é o patriarca Jacó, que amava especialmente sua esposa Raquel. Jacó também amava sua outra esposa, Lea, mas em relação a Raquel, havia algo mais. Da mesma maneira,

\footnotetext{
${ }^{471}$ Besdin, 1993, pg. 36.

472 Besdin, 1993, pg. 37.

${ }^{473}$ Soloveitchik, HaAdam Ve-Olamo, pgs. 167 e 168.

${ }^{474}$ tradução proposta por Rashi.
} 
Jacó amava todos seus filhos, mas em relação a José, dedicava um amor especial: "Israel preferia José a todos os seus filhos" (Gn 37:3) ${ }^{475}$.

$\mathrm{Na}$ concepção de Soloveitchik, um relacionamento sgulah envolve um “entrelaçamento de almas, uma união que vai além da descrição verbal. É mais que amor emocional. É uma unidade alcançada que representa o mais alto degrau de identificação. Um amor sgulah é uma fusão ontológica”. É neste sentido que o povo de Israel é sgulah, ou seja, valorizado especialmente por Deus, mas sem envolver rebaixamento de outras nações. Em relação aos judeus, Deus designou-os para preservar e disseminar seus ensinamentos ${ }^{476}$.

Este relacionamento sgulah entre Deus e o povo judeu não poderia se modificar como consequência do Holocausto. Isto porque a perseguição contra os judeus não tem um significado profundo, pois a atitude anti-semita é basicamente ilógica ${ }^{477}$. Não há uma explicação racional para a situação "absurda" ${ }^{478}$ de ódio gratuito que acompanha o judeu desde o início de sua história ${ }^{479}$.

\footnotetext{
${ }^{475}$ Besdin, 1993, pgs. 119 e 120 / Soloveitchik, HaAdam Ve-Olamo, pgs. 167 e 168.

${ }^{476}$ Besdin, 1993, pg. 120.

477 Soloveitchik, 1992, pg. 24.

${ }^{478}$ Besdin, 1993, pg. 182.
}

${ }^{479}$ Sobre o relacionamento inamistoso entre os judeus e outros povos, Soloveitchik abordou-o em seu comentário aos capítulos 32 a 36 de Gênesis (que na Bíblia Hebraica fazem parte de um mesmo conjunto ou parashah). Segundo o pensador, Gênesis é um livro que não se restringe apenas a relatar fatos do passado, mas também mostra "sinais" relacionados a eventos futuros que envolveriam o povo judeu. No caso desta parashah, o que estaria em questao seria o tema "guerra entre Israel e os povos através da História".

Nesta parashah, é narrado o episódio da luta de Jacó com um ser misterioso, durante a travessia do rio Yaboq, visto por Soloveitchik como o prenúncio das futuras perseguições sofridas pelo povo judeu:

"[Jacó] levantou-se naquela mesma noite, tomou suas duas mulheres, suas duas servas e seus onze filhos e transpôs o [rio] Yaboq (...) Fez passar tudo o que lhe pertencia, ficando ele só. E lutava com ele um homem, até o romper do dia. Vendo este que não podia com ele, tocou-lhe na articulação da coxa; deslocou-se a junta da coxa de Jacó, na luta com o homem. Disse este: 'Deixa-me ir, pois já rompeu o dia'. Respondeu Jacó: 'Não te deixarei ir se não me abençoares'. Perguntou-lhe pois: 'Como te chamas?' Ele respondeu: 'Jacó'. Então disse: 'Já não te chamarás Jacó e sim Israel, pois como príncipe lutaste com Deus e com os homens, e prevaleceste'. Tornou Jacó: 'Dize, rogo-te, como te chamas? ' Respondeu ele: 'Por que perguntas pelo meu nome?' E o abençoou ali (Gn 32: 22 a 29) "

Para Soloveitchik, o mistério que cerca este relato e a recusa do ser misterioso em se identificar são prenúncios das lutas históricas entre Israel e os povos. "Na maior parte dos casos, o judeu não sabia nem sequer a identidade dos que lutavam contra ele", escreve. Da mesma maneira que o ser misterioso não respondeu ao pedido de Jacó para se identificar, também os "odiadores de Israel" não se dão o trabalho de explicar suas razões. Para Soloveitchik, isto mostra a total falta de lógica na perseguição aos judeus.

$\mathrm{Na}$ narrativa, o ser misterioso acaba por libertar Jacó e abençoa-o. Mas na leitura de Soloveitchik, o fato do ser misterioso ter se despedido de Jacó "sem prometer nada", isto significa que o conflito não terminou ali e que a luta contra Israel continuaria acontecendo no futuro.

(Soloveitchik, 1992, pgs. 22 a 24) 
Neste mesmo bloco de capítulos (parashah) interpretado por Soloveitchik, a Biblia Hebraica trata do povo edomita (Gn 36). Este povo, que vivia na fronteira sul de Judá, era tido pelos autores bíblicos como descendente de Esaú, irmão de Jacó. Mas apesar da proximidade de parentesco, os autores bíblicos viram Edom como um inimigo ferrenho de Israel. Esta avaliação está presente em livros como Amós (1:11) e Ezequiel (35:5), entre outros. A visão judaica negativa em relação a Edom continuou mesmo após este povo ter desaparecido da história. O judaísmo pós-bíblico continuou execrando "Edom" e os rabinos identificaram o império romano e a Igreja Católica como "edomitas", em seus períodos de perseguição contra os judeus.

(Herr, 1972, pgs. 369 a 379)

Daí entende-se a razão de Soloveitchik interpretar a seguinte passagem, que narra o reencontro de Jacó com Esaú, como um sinal negativo de acontecimentos futuros na relação entre o povo judeu e os outros povos:

"Jacó levantou os olhos e viu que Esaú se aproximava (...) Esaú disse: 'Levantemos acampamento e partamos. Eu caminharei a teu lado'. Porém Jacó respondeu-lhe: 'Meu senhor sabe que as crianças são frágeis e que tenho comigo ovelhas e vacas que amamentam; se forem tocadas com pressa, mesmo só por um dia, todo o rebanho pode morrer. Passe meu senhor adiante de seu servo. Quanto a mim, caminharei devagar, ao passo do rebanho que me precede e ao passo das crianças, até chegar perto de meu senhor em Seir'. Esaú respondeu: 'Então permita que eu deixe contigo alguns dos que estão comigo'. Disse Jacó: 'Para que? Basta-me encontrar graça aos olhos de meu senhor!'. Naquele mesmo dia, Esaú retomou seu caminho para Seir, enquanto Jacó partiu para Sukot” (Gn 33:12 a 17)

$\mathrm{Na}$ interpretação de Soloveitchik, o convite de Esaú para "andarem lado a lado", recusado por Jacó, refere-se ao argumento anti-semita de que os judeus - os descendentes de Jacó - insistem em caminhar sozinhos e não na companhia de outros povos. O rabino afirma concordar com este argumento. Os judeus realmente têm um estilo-de-vida diferente e "até numa coisa simples como a escrita, escrevem da direita para a esquerda, de maneira contraria à maioria da humanidade".

Para Soloveitchik, a singularidade do povo judeu causa contrariedade e perturbação. O resultante antisemitismo representa a falta de compreensão e tolerância em relação ao estilo-de-vida singular dos judeus. $\mathrm{O}$ anti-semita, tanto o antigo quanto o moderno, não consegue penetrar no mundo mais profundo dos judeus, para compreendê-lo.

Para o rabino, a Bíblia Hebraica indica que, em todas as gerações seguintes, não haveria descanso para os judeus e aconteceriam "milhares" de conflitos com os descendentes de Esaú. Ele afirma que somente no futuro, após um longo e doloroso processo histórico, é que este conflito cessará e haverá uma decisão final a favor de Israel. Isto acontecerá na era messiânica, quando os descendentes de Esaú reconhecerão o Deus de Jacó.

(Soloveitchik, 1992, pgs. 24 a 27)

Ainda sobre o relacionamento dos judeus com outros povos, Soloveitchik afirma que o Livro de Ester traz outros esclarecimentos. Os judeus da Pérsia descobriram que, de vez em quando, o ser humano troca seu caráter de imagem de Deus por um caráter onde se reconhece Satã. Quando isto aconteceu na Pérsia, durante a vida de Ester, foi muito difícil para o judeu compreender a situação. Isto porque o judaísmo acredita que em todo ser humano encontra-se latente uma centelha divina e que, em qualquer circunstância, reside no interior do ser humano algo de bom, daí a idéia de que o indivíduo sempre pode se arrepender (tshuvah) e voltar ao caminho correto. A sensibilidade ética e o respeito ao próximo foram marcados de maneira bem sucedida na personalidade do judeu através da experiência no Egito e, posteriormente, foi reforçada pela pregação dos profetas.

Mas isto não deveria cegar os judeus à dura realidade. Os judeus da Pérsia basearam sua segurança na natureza positiva do ser humano, assim como o fizeram os judeus da Alemanha pré-Hitler. Mas, repentinamente, descobriram que o ser humano pode se transformar numa personalidade satânica, num símbolo de maldade e iniquidade.

(Soloveitchik, 1992, pgs. 216 e 217 / Besdin, 1993,pg. 181)

Em sua interpretação do Livro de Ester, o rabino cita Amalek, um outro povo-símbolo na consciência judaica. Historicamente, os amalequitas viveram no deserto do Negev (sul de Judá) e, segundo a Bíblia, foram os primeiros a atacar os israelitas quando fugiam do Egito sob o comando de Moisés (Ex 17:8). A partir de então, passaram a simbolizar no judaísmo a figura do inimigo irreconciliável de Israel. No Livro de Ester, Haman, o ministro da corte persa que pretendeu assassinar os judeus do reino, era descendente de Agag, rei amalequita do tempo de Samuel (Es 3:1).

(Halevy, 1971, pgs. 787 a 791)

Para Soloveitchik, o Livro de Ester mostra como Amalek atua na história. Ele é um inimigo de todo o gênero humano, mas ataca primeiramente e especialmente o judeu. Isto não tem uma explicação racional. Apenas a existência do judeu já provoca ódio em Amalek, como disse o personagem bíblico 
Mas por que um povo sgulah precisa passar por tal tormento durante a História? Não é possível compreender plenamente o significado de ser um povo sgulah, da mesma maneira que não se entende o significado de uma região do mundo ser "terra prometida", esclarece Soloveitchik. Por que este povo precisa permanecer por tanto tempo em exílio e privação? O homem não compreende as razões e os segredos do conceito de sgulah em seu sentido mais profundo. Não se sabe quando e em que situações ocorrerão as revelações ligadas a uma situação de $s g u l a h^{480}$.

\section{6 -}

Soloveitchik refletiu sobre as catástrofes que ocorrem na História, sem citar especificamente o Holocausto. Ele afirmou que o judaísmo não aceita a idéia de que acontecimentos históricos ocorrem ao acaso ou que sejam absurdos. Eventos não são causados por "destino cego" ou pura sorte. Da mesma maneira, catástrofes não acontecem de maneira ilógica ou sem explicação ${ }^{481}$.

Alguns eventos podem permanecer sem uma explicação racional, mas isso porque a razão humana não consegue penetrar nos desígnios de Deus. Eventos incompreensíveis pela mente humana são classificados pelo judaísmo como "irregulares e anormais" 482 .

\footnotetext{
Haman: "Mas nada disso (honrarias e riquezas) tem valor para mim, cada vez que vejo Mordehai, o judeu, sentado à porta real" (Est 5:13). Este ódio de Amalek toma os judeus de surpresa, como também aconteceu no caso da Solução Final nazista.

(Soloveitchik, 1992, pgs. 217 e 218)

Para Soloveitchik, a história de Ester indica como Amalek pode ser combatido. Sempre que Amalek se levanta contra Israel, ele é enfrentado por um mensageiro de Deus. Assim como Mordehai e Ester surgiram para derrotar Haman, em todos os momentos de crise com Amalek um ser humano é usado como agente para implementar o plano de Deus. O "titânico confronto" entre o mensageiro de Deus e o homem-Satã precisa ocorrer para acontecer a redenção. Isto é necessário, pois é somente nesse encontro que se incute no homem justo a capacidade de compaixão e de amor pela humanidade.

(Epstein, 1994, pgs. 179 e 180)

A guerra dos judeus contra Amalek já dura milênios e apenas terminará na era messiânica. Até lá, o conflito continuará, pois Amalek não é uma certa pessoa que surge na História por acaso, mas sim a essência do mal e da iniquidade. No século XX, os nazistas e a ditadura soviética foram "semente de Amalek".

(Soloveitchik, 1992, pg. 217)

${ }^{480}$ Soloveitchik, HaAdam Ve-Olamo, pg. 175.

${ }^{481}$ Soloveitchik, 1992, pgs. 214, 215.

${ }^{482}$ Soloveitchik, 1992, pgs. 214, 215.
} 
É necessário notar, aponta Soloveitchik, que determinado acontecimento que parece totalmente ilógico no momento em que ocorre, pode revelar um significado importante posteriormente. A partir de uma maior perspectiva obtida pelo passar do tempo, é possível comparar este acontecimento com outros eventos e compreender melhor as forças que estavam envolvidas ali. Assim, é possivel futuramente se chegar a uma boa explicação racional para o ocorrido ${ }^{483}$.

Nesta nova situação, em que um acontecimento antes tido como absurdo tornase compreensível, o homem também passa a ser visto como uma criatura totalmente lógica. "Um grande evento histórico dramático (...) depois de passar um tempo considerável (...) pode ser visto como um encontro real entre o ser humano e o Criador do mundo", escreve ${ }^{484}$.

Por outro lado, afirma Soloveitchik, a história dos judeus é diferente da história dos demais povos. Esta última é governada pela causalidade: todo evento é gerado por uma causa que o precede e os acontecimentos se desenvolvem quase mecanicamente. Como consequência, os historiadores podem analisar os acontecimentos humanos através do princípio de que a causalidade comanda os eventos futuros. Mas quando estes mesmos historiadores tentam interpretar a história judaica aplicando este princípio, chegam a "conclusões bizarras e distorções" ${ }^{485}$.

Isto por que a história judaica é modelada pelo destino, por um objetivo colocado no futuro. É “teleológica", sendo propulsionada por um propósito. O que acontece com os judeus emana de uma promessa divina prevista para o futuro, mais do que por eventos do passado. A história judaica não é empurrada por antecedentes causais, mas sim é puxada, como por um imã, em direção a um destino glorioso ${ }^{486}$.

Soloveitchik fornece um exemplo: a determinação passional e quase irracional dos judeus para estabelecer o Estado de Israel e seus esforços para assegurar a existência deste país contra a oposição de "quase todo o mundo". Segundo ele, isto

\footnotetext{
${ }^{483}$ Soloveitchik, 1992, pg. 215.

${ }^{484}$ Soloveitchik, 1992, pg. 215.

${ }^{485}$ Besdin, 1989, pg. 70.

${ }^{486}$ Besdin, 1989, pg. 70.
} 
não pode ser explicado como mais um caso de nacionalismo típico do século XIX ou mesmo como uma reação aos horrores do Holocausto ${ }^{487}$.

Outras nações sofreram desastres menos dramáticos em comparação aos que atingiram os judeus, mas mesmo assim acabaram sucumbindo aos imperativos do declínio histórico. Mas com os judeus foi diferente. Nem o Holocausto foi capaz de deprimi-los ou confundi-los. Eles ressurgiram energizados, com um ardor suprahumano pelo sonho de um futuro que nem as chamas dos crematórios puderam extinguir $^{488}$.

O que determina a experiência histórica judaica não é o ponto de partida, mas o destino. O judeu em sua história é como um viajante que deseja chegar a um destino o mais rápido possível. Muitas vezes ele é desviado de seu caminho, mas acaba retornando e retomando sua jornada ${ }^{489}$.

Qual é este destino judaico? É a redenção escatológica, os Últimos Dias. Não só do judeu e não apenas da humanidade, mas de todo o universo. A era messiânica é o sonho do judaísmo e o objetivo espiritual da história judaica ${ }^{490}$.

\section{7 - Martírio (Kidush Ha-Shem)}

Soloveitchik não tratou do tema Kidush Ha-Shem em sua obra de nenhuma maneira que poderíamos relacioná-la ao Holocausto. O professor Shalom Carmy, especialista na obra de Soloveitchik da Yeshiva University (NY), afirmou em comunicação ao autor desta pesquisa que "ele (Soloveitchik) parece não ter tratado do tema (Kidush Ha-Shem) no contexto teológico" 491.

\footnotetext{
${ }^{487}$ Besdin, 1989, pgs. 70, 71.

${ }^{488}$ Besdin, 1989, pg. 71.

${ }^{489}$ Besdin, 1989, pgs. 71 e 72.

${ }^{490}$ Besdin, 1989, pg. 72.

${ }^{491}$ cartas ao autor datadas de $8 / 5 / 05$ e 9/5/05.
} 
O professor David Shatz ${ }^{492}$, da cadeira de Judaísmo da Yeshiva University, e Reuven Ziegler ${ }^{493}$, editor de obras de Soloveitchik, também desconhecem passagem na obra de Soloveitchik que trate de Kidush Ha-Shem relacionado ao Holocausto.

\section{8 - Singularidade do Holocausto}

Comentaristas da obra de Soloveitchik são uninâmes em afirmar que o rabino não opinou diretamente sobre a Singularidade do Holocausto. David Shatz afirma desconhecer qualquer texto onde o rabino tenha se expressado sobre esta questão ${ }^{494}$. Shalom Carmy duvida que Soloveitchik tenha refletido sobre o tema ${ }^{495}$.

Já Reuven Ziegler opina que Soloveitchik não considerou o Holocausto como um evento único na história judaica ${ }^{496}$. Ziegler baseia sua percepção no relato de um encontro entre o rabino e o então primeiro-ministro de Israel, Menachem Begin, nos Estados Unidos, quando solicitou ao político que cancelasse o Dia do Holocausto, observado em Israel ${ }^{497}$.

Soloveitchik foi contrário à criação de um dia especial no calendário judaico para a lembrança do Holocausto ${ }^{498}$, uma indicação de que não considerava a Shoá como um evento singular. O rabino opinou que todos os hurbanot da história judaica deveriam ser lembrados num só dia de luto, Tishah Be-Av ${ }^{499}$, incluindo a Shoá ${ }^{500}$.

\footnotetext{
492 carta ao autor datada de $8 / 5 / 05$.

493 carta ao autor datada de $9 / 5 / 05$.

494 carta ao autor datada de $8 / 5 / 05$.

495 cartas ao autor datadas de $8 / 5 / 05$ e $9 / 5 / 05$.

496 carta ao autor datada de $9 / 5 / 05$.

${ }^{497}$ Lichtenstein, pg. 155.

${ }^{498}$ Weiss, 2005, pg. 117.

499 Tishah be-Av (תשעה באב) - "dia 9 do mês (hebraico) Av". Dia de luto pela destruição do Primeiro e Segundo Templos de Jerusalém. Nesta data também são lamentadas nas sinagogas outras catástrofes da história judaica, como a derrota final da revolta de Bar Kokhba (ano 135) e a Expulsão da Espanha (1492).

${ }^{500}$ Neste ponto, Soloveitchik reforça a tradicional avaliação ortodoxa sobre uma inacapacidade da liderança religiosa judaica contemporânea para introduzir modificações na tradição. Ele escreveu: "Não acredito em criatividade litúrgica. Não creio que nenhum de nossos contemporâneos possui a habilidade, a fé, a profundidade (...) ou a pureza de alma para se permitir escrever piyut. Apenas os Homens da Grande Assembléia ou os profetas puderam fazer isto. Os Ba'alei ha-Tosofos também puderam, pois foram os ancestrais dos hakhmei ha-mesorah (...) Mas nenhum contemporâneo tem todas as qualidades indispensáveis para a assim chamada criatividade litúrgica" (citado in Weiss, 2005, pgs. 117 e 118).
} 
“As cenas descritas e as palavras de desespero, luto e pesar são as mesmas (...)

Nenhum novo dia de comemoração ou jejum deveria ser designado para o Holocausto", afirmou ${ }^{501}$.

\section{9 - Livre Arbítrio}

Soloveitchik não se pronunciou sobre a questão do Livre-Arbítrio em relação ao Holocausto. Shalom Carmy afirma desconhecer pronunciamento do rabino sobre o tema ${ }^{502}$, assim como David Shatz ${ }^{503}$.

\footnotetext{
${ }^{501}$ citado in Weiss, 2005, pg. 118.

502 cartas ao autor datadas de $8 / 5 / 05$ e $9 / 5 / 05$.

${ }^{503}$ carta ao autor datada de $8 / 5 / 05$.
} 


\section{6 - O HOLOCAUSTO NO PENSAMENTO DE ELIEZER BERKOVITS}

\section{$\underline{6.1 \text { - Biografia }}$}

Eliezer Berkovits ${ }^{504}$ nasceu em 1908 em Oradea (atual Romênia) e recebeu educação religiosa tradicional, culminando em sua ordenação como rabino pelo seminário ortodoxo moderno Hildesheimer, na Alemanha. Quase ao mesmo tempo, com 25 anos de idade, doutorou-se em Filosofia pela Universidade de Berlim, com tese sobre o filósofo David Hume. Serviu como rabino na Alemanha, mas deixou o país após a subida dos nazistas ao poder. Sua mãe, duas irmãs e um irmão foram mortos no Holocausto. A partir de 1938, exerceu o rabinato na Inglaterra e Austrália e, em 1950, fixou-se nos Estados Unidos. Serviu a comunidade judaica de Boston e, na área acadêmica, chefiou o Departamento de Filosofia Judaica do Hebrew Theological College, em Chicago. Em 1975, imigrou para Israel, onde faleceu 17 anos mais tarde.

\section{$\underline{6.2-\text { Obra }}$}

Berkovits escreveu 19 livros ${ }^{505}$ e dezenas de artigos sobre diferentes aspectos da vida judaica: tratou da aplicação da halakhah no mundo contemporâneo, polemizou com o historiador Arnold Toynbee, abordou os problemas contemporâneos do Estado de Israel, escreveu comentários sobre a Biblia Hebraica, o papel da mulher na sociedade, educação, entre outros assuntos.

Mas foi sua reflexão sobre o Holocausto, especialmente em sua mais importante obra, Faith After the Holocaust, que o colocou entre os mais importantes pensadores judeus do século XX. Também abordou a Shoá em outra obra, With God in Hell - Judaism in the Ghettos and Deathcamps, e em ensaios e capítulos de outros livros.

\footnotetext{
${ }^{504}$ Halkin, 1972, pgs. 633 e 634 / Hazony, 2001, pg. 108 / Hazony, 2007, pgs. 438 e 439 / CohnSherbok, 1997, pg. 19 / Raffel, 1993, pgs. 1 e 2 / Berkovits, With God in Hell, pg. vii.

${ }^{505}$ Hazony, 2001, pg. 108.
} 
Um elemento a ser destacado em sua reflexão sobre o Holocausto é a presença, em algumas passagens, de um tom marcadamente emocional. Ao lado de finas reflexões, onde mostra seu amplo conhecimento do pensamento judaico, Berkovits também deixa transparecer sua revolta apaixonada em relação à Shoá, o que acaba interferindo, em alguns momentos, na qualidade de sua reflexão. Este emocionalismo talvez seja a razão do pensador ter esposado a visão mais exclusivista e "nacionalista" do judaísmo quando trata de temas como Povo Eleito ou História.

Isto não impediu que a qualidade da reflexão de Berkovits sobre o Holocausto recebesse amplo reconhecimento entre os críticos. Jonathan Sacks o considera como o pensador que "expressa de maneira mais acurada uma autêntica resposta judaica [à Shoá]" 506 . Eliezer Schweid descreveu sua obra como "o mais sério esforço" feito por um pensador ortodoxo moderno nesta área ${ }^{507}$. Michael Morgan, da Indiana University, classificou Faith After the Holocaust como "uma tentativa moralmente apaixonada de confrontar [o Holocausto] com total seriedade e honestidade" ${ }^{508}$. Steven Katz, da Boston University, elogiou esta obra por "destacar elementos seminais que precisam ser considerados em qualquer resposta a Auschwitz" ${ }^{509}$. Charles Raffel viu neste livro uma "teodicéia judaica séria, sofisticada, tradicional e variada (...) é [um livro] impressionante, controverso, desafiador, senão convincente" ${ }^{\mathrm{5} 10}$.

Mas seus comentaristas também fizeram críticas negativas. Morgan considerou Faith After the Holocaust uma obra "excessivamente chauvinista (..) sua escrita é inflada e altamente retórica" ${ }^{511}$. Também criticou o autor por conceder valor religioso a uma sociedade secular como a israelense ${ }^{512}$. Eliezer Schweid afirmou que a reflexão de Berkovits sobre o conceito de Ocultamento da Face não encontra respaldo na tradição judaica ${ }^{513}$. Já Zachary Braiterman apontou uma contradição no pensamento de Berkovits, quando este afirma que o Holocausto não foi um evento

\footnotetext{
${ }^{506}$ in Cohn-Sherbok, 2002, pg. 158.

${ }^{507}$ Schweid, 1994, pg. 335.

${ }^{508}$ Morgan, 1992, pg. 97.

${ }^{509}$ Katz, 1983, pg. 163.

${ }^{510}$ Raffel, 1993, pgs. 5, 11, 12

${ }^{511}$ Morgan, 1992, pg. 172 (nota 4).

${ }^{512}$ Morgan, 2001, pg. 117.

${ }^{513}$ Schweid, 1994, pgs. 349 e 350.
} 
singular do ponto-de-vista teológico e, por isso, não alterou as bases do judaísmo. "O próprio Berkovits foi um revisionista sutil, que reescreveu e releu a tradição judaica à luz de um desastre moderno único", apontou Braiterman ${ }^{514}$.

\section{3 - O Holocausto no pensamento de Berkovits}

\section{1 - $\underline{\text { Singularidade do Holocausto }}$}

Em Faith After the Holocaust ${ }^{515}$, Berkovits defende a idéia de que a Shoá, apesar de ter sido uma tragédia judaica inédita em termos numéricos, não foi diferente de outras catástrofes do passado do ponto-de-vista teológico. "Tivemos inumeráveis Auschwitzes (sic). Duas destruições de templos (...), a destruição do grande judaísmo espanhol (...), Cruzadas, Peste Negra e os massacres de Chmelnicki (...)" ${ }^{516}$.

Por isso, para Berkovits, o problema de fé trazido pelo Holocausto não foi diferente do problema colocado por catástrofes anteriores. Ele se pergunta: "O problema de fé em Deus foi menos sério durante a Peste Negra porque naquela época apenas metade dos 500 mil judeus europeus morreram, e não 6 milhões nos nossos dias?" ${ }^{517}$. Berkovits afirma que as dúvidas de fé trazidas pelo Holocausto não apenas são repetições do passado, como também repetições que acontecem praticamente desde o início do judaísmo.

Como o problema de fé é o mesmo, Berkovits permite-se aplicar ao Holocausto as mesmas idéias utilizadas por gerações passadas de pensadores judeus para enfrentar desafios teológicos similares ${ }^{518}$. Para ele, o judaísmo tem elementos suficientes para possibilitar o entendimento do que aconteceu na Europa nazista.

\footnotetext{
${ }^{514}$ Braiterman, 1998,pg. 115.

Braiterman classificou Berkovits como um pensador "radical" no interior da ortodoxia, por ter baseado algumas de suas afirmações em visões minoritárias dentro do judaísmo, como no caso do apóstata Aher, que veremos abaixo. (Braiterman, 1998, pgs. 113, 114).

${ }^{515} \mathrm{Na}$ exposição deste capítulo, a obra Faith After the Holocaust foi utilizada como eixo principal da apresentação. Informações contidas em outros livros e ensaios de Berkovits, bem como observações dos comentadores de sua obra, foram adicionadas a este eixo principal.

${ }^{516}$ Berkovits, 1973, pg. 90.

${ }^{517}$ Berkovits, 1973, pg. 90.

${ }^{518}$ Barkovits, 1973, pgs. 90 e 91.
} 
Mas Berkovits também deixa claro que todo seu esforço intelectual para entender o Holocausto não significa que pretenda fazer um exercício de teodicéia, ou seja, justificar a divindade ${ }^{519}$. Para o pensador, em última análise, a Shoá foi uma injustiça absoluta ${ }^{520}$ permitida por Deus, que tem a responsabilidade última por ter criado um mundo onde existe uma falta crônica de justiça. "O domínio de Deus sobre o mundo não é um domínio de justiça. Em termos de justiça, Ele é culpado, culpado pela Criação" 521 .

Por outro lado, Berkovits ressalva que a história judaica não pode ser resumida ao Holocausto, pois houve também eventos positivos, como a libertação do Egito, a entrega da Lei, o envio dos profetas e o fim do exílio da Babilônia. Mas a malignidade da Shoá leva o rabino a afirmar que Deus permanece em débito para com Seu povo ${ }^{522}$.

\section{2-Martírio (Kidush Ha-Shem)}

Berkovits reconhece a falta de unanimidade entre os pensadores do Holocausto sobre a existência de martírio numa situação em que as vítimas não tiveram outra opção, a não ser serem assassinadas. Mas ele afirma sua opinião de que houve Kidush Ha-Shem durante a Shoá. "Um dos trágicos mal-entendimentos de nossa geração é achar que, durante a era alemã-nazista na Europa. os judeus foram roubados até mesmo da oportunidade de preservar suas dignidades através da santificação do nome divino (...) Nada poderia estar mais distante da verdade", escreve ${ }^{523}$.

Para Berkovits, o modelo medieval de martírio é apenas uma das variantes de Kidush Ha-Shem. Outra variante, mais frequente no Holocausto, é aquela descrita no

\footnotetext{
${ }^{519}$ Berkovits, 1973, pgs. 89 e 128.

${ }^{520}$ O Holocausto foi “injustiça absoluta, injustiça permitida por Deus” (Berkovits, 1973, pg. 94).

${ }^{521}$ Berkovits, 1973,pg. 131.

${ }^{522}$ Berkovits, 1973, pgs. 134 e 136.

${ }^{523}$ Berkovits, 1973, pg. 80
} 
Talmud da Babilônia, a respeito do suplício de Rabi Akiva ${ }^{524}$. O evento é narrado no Tratado Berakhot 61b:

O governo perverso (Roma) baixou um decreto que os israelitas não deveriam mais estudar a Torá. Papos ben Judah encontrou Rabi Akiva ajuntando multidões em público e estudando a Torá (...) A hora em que trouxeram Rabi Akiva para ser morto era o momento de recitar [a prece] 'Ouça Israel' ${ }^{525}$. Eles estavam penteando sua carne com um pente de ferro enquanto ele (Akiva) aceitava o jugo do Reino do Céu (que ordena a recitação da prece). Seus discípulos o questionaram: Mestre, até este ponto? ${ }^{526}$ Respondeu-lhes: Durante toda minha vida perturbei-me com os versículos 'com toda sua alma' (da prece 'Ouça Israel'), [que significa] mesmo que tire sua alma. Eu me perguntava quando eu teria o privilégio de cumprir este mandamento. Agora que tenho a oportunidade, não deveria cumpri-lo? Ele (Akiva) segurou [a recitação] da palavra "um” (da prece 'Ouça Israel') até sua alma expirar no 'um' (enquanto recitava a palavra 'um'). Uma voz divina então proclamou: 'Feliz é você, Rabi Akiva, por sua alma ter expirado com a palavra 'um'. Os anjos disseram perante Deus: 'Esta é a Torá e esta é a sua recompensa?' Uma voz divina então proclamou: 'Feliz é você, Rabi Akiva, pois foi selecionado para a vida no mundo vindouro'.

Berkovits sublinha ${ }^{527}$ a atitude de Akiva, que no momento de seu suplício, concentrou-se no cumprimento de um mandamento religioso e até extraiu um novo significado (para o versículo "com toda sua alma"), indiferente aos soldados romanos que abusavam de seu corpo. Esta situação é ainda pior que a dos judeus medievais, que optaram pelo suicídio quando poderiam ter escolhido o batismo e, portanto, não poderiam acusar a divindade de tê-los abandonado completamente.

A situação vivida por Akiva, similar a de judeus em guetos e campos-deconcentração nazistas, abriu a possibilidade de vivenciar o que o Berkovits classificou como "a mais elevada forma" de martírio. É quando não existe uma opção para salvar

\footnotetext{
${ }^{524}$ Berkovits, 1973, pg. 80

${ }^{525}$ A prece está em Dt 6:4 e.d. : “Ouça Israel, Jeová é nosso Deus, Jeová é um. E amará Jeová seu Deus com todo seu coração, com toda sua alma e com toda sua posse"

526 significando: "uma pessoa está obrigada a cumprir um mandamento religioso mesmo nesta situação?"

${ }^{527}$ Berkovits, 1973, pg. 81
} 
a própria vida e parece que Deus abandonou o indíviduo, mas este, mesmo assim, exalta-O. "Se, neste momento, [o indivíduo] é capaz de aceitar seu abandono radical por Deus como um presente (...) que o capacita a amar seu Deus com toda sua alma (...) ele atingiu a mais elevada forma de Kidush Ha-Shem”, afirma Berkovits ${ }^{528}$.

O mesmo tipo de Kidush Ha-Shem adotado por Akiva ${ }^{529}$, segundo Berkovits, ocorreu em "dezenas de milhares" 530 de casos em guetos e campos-de-concentração. Berkovits exemplifica com alguns relatos de testemunhas do genocídio: um judeu religioso idoso do Gueto de Varsóvia que se recusou a descobrir a cabeça ao passar por guardas nazistas e foi brutalmente espancado; um grupo de hassidim numa estação de trem a caminho de Treblinka que abençoou uma mísera refeição entoando o salmo "O Senhor é meu pastor"; um grupo de hassidim no campo-de-concentração de Plaszow que dançou em êxtase ao perceber que morreriam como mártires, pouco antes de seu fuzilamento ${ }^{531}$.

3 - 企

Outros judeus, porém, adotaram uma postura distante do martírio. Berkovits passa a examinar então aqueles que sofreram uma crise de fé como resultado do Holocausto. O rabino considera a postura de se questionar "onde estava Deus" ou “como Ele permitiu tal sofrimento” não apenas legítima, como também necessária; é uma atitude correta e, deixar de fazê-lo, seria uma blasfêmia ${ }^{532}$.

Para Berkovits, tais questionamentos são uma atitude aceita pelo judaísmo e estão presentes, por exemplo, no Livro de Jó ${ }^{533}$. Este personagem bíblico foi alvo de

\footnotetext{
${ }_{528}^{528}$ Berkovits, 1973, pg. 81.

529 Deve-se notar que, em outros momentos de sua reflexão, Berkovits classifica como martírio algumas situações do Holocausto onde a motivação religiosa não está muito clara. Por exemplo, ele considera mártir uma prisioneira de Maidanek executada por se recusar a delatar companheiros que a auxiliaram em sua tentativa frustrada de fuga. Ele também chama de mártir o célebre educador Janusz Korczak, um judeu secular que optou por acompanhar as crianças de seu orfanato no Gueto de Varsóvia para a morte no campo-de-concentração de Treblinka, mesmo tendo a possibilidade de salvarse (1973, pgs. 33 e 34$)$.

${ }^{530}$ Berkovits, 1973, pg. 82.

${ }^{531}$ Berkovits, 1973, pgs. 83 e 84 / Berkovits, With God..., pgs. 111 e 112.

${ }^{532}$ Berkovits, 1973, pgs. 68 e 68.

${ }^{533}$ Berkovits, 1973, pg. 68.
} 
injustiça, assim como as vítimas do Holocausto. Daí que a mesma postura aguda de questionamento da justiça divina que Jó assume, também é justificada quando assumida pela geração do Holocausto ${ }^{534}$. Os judeus da nossa era, quando considerados como uma unidade nacional, têm exatamente as mesmas dúvidas sobre a justiça divina que o personagem Jó teve nos tempos bíblicos. "Não justificaremos a sentença, do mesmo modo que Jó não a justificou”, escreve Berkovits ${ }^{535}$.

Após examinar a postura dos judeus durante o Holocausto - seja como mártires, seja como argumentadores - Berkovits passa a refletir sobre a postura do próprio Deus na Shoá.

\section{4 - $\underline{\text { História como Revelação Divina }}$}

O judaísmo, especialmente na Bíblia Hebraica, afirma Berkovits, contém uma "lei da história" ${ }^{536}$ que pode ser resumida da seguinte maneira: Deus fez conhecer aos homens regras de comportamento que devem ser seguidas; quando estas regras são observadas, judeus e não-judeus são abençoados; mas se estas leis são violadas ou esquecidas, vem o castigo. O curso dos acontecimentos é, então, determinado pelo Deus de Israel segundo esta "lei da história". Isto resulta num processo em que Deus destrói os pecadores e faz com que o justo prospere. "Deus é um Deus da História", conclui $^{537}$.

\footnotetext{
${ }^{534}$ Sobre a total adaptabilidade do modelo teológico de Jó ao caso do Holocausto, Berkovits se contradiz. Em Faith After the Holocaust (pg. 69), o rabino aponta para a discrepância entre o final do Livro de Jó e o destino das vítimas do nazismo: enquanto Jó recebe uma revelação divina (Jo 38:1) e morre em paz, recompensado e reconciliado com Deus (Jo 42:10 a 17), na Shoá "infelizmente, diferentemente do caso de Jó, Deus permaneceu em silêncio até o fim da tragédia e os milhões nos campos-de-concentração foram abandonados em meio ao desespero infinito (...) Milhões procuraram por Ele, em vão".

Já numa obra posterior, Mashber HaYahadut Be-Medinat HaYehudim (pgs. 10 e 11), o rabino afirma o oposto: houve uma revelação divina para os sobreviventes da Shoá, semelhante àquela vivenciada por Jó. Esta revelação foi o Estado de Israel, cujo estabelecimento é interpretado por Berkovits como uma resposta de Deus às dúvidas levantadas pela Shoá. Esta revelação, para o pensador, teve o poder de dirimir questões de fé. "Quando [Deus] se revela ao homem (...) então é possível viver com o incompreensível e se renovar com a benção de Deus. Assim eu vejo o significado do estabelecimento do Estado na sequência da Shoá (...) Com nossos olhos vimos a presença do Senhor dos Mistérios na história, chamando-nos para vidas renovadas", escreve.

${ }_{535}^{535}$ Berkovits, 1987, pg. 9

${ }_{536}^{536}$ Berkovits, 1973, pgs. 91 e 92

${ }^{537}$ Berkovits, 1973, pg. 91
} 
Como afirma Berkovits, esta "lei da história" traz como consequência uma óbvia questão ${ }^{538}$ : se o Deus justo maneja a História, por que o sofrimento do inocente? Como resposta, o rabino afirma que seria "a pior forma de antropocentrismo" sugerir que um Deus onisciente e onipresente somente pudesse criar um universo imaculado ${ }^{539}$. Talvez o homem, se fosse poderoso o suficiente, criaria um universo puro, mas é errado pensar que Deus também seja obrigado a seguir este caminho. "O Deus perfeito desejou criar um mundo imperfeito", escreve $^{540}$.

Berkovits aponta uma lógica num Deus todo-poderoso que cria um mundo imperfeito ${ }^{541}$ : somente Deus é perfeito e, se o mundo não fosse imperfeito, não se diferenciaria do seu Criador e voltaria a se fundir a Ele. Uma criação perfeita, sem a presença do mal, não poderia se diferenciar de Deus. Por isso, a Criação precisa do mal para se manter independente; mas, por causa desta presença, manter-se-á eternamente imperfeita.

No mundo, então, existem o bem e o mal ${ }^{542}$. Para Berkovits, foi o profeta Isaías quem, corajosamente, enfrentou a consequência lógica do monoteísmo: se há um único Deus no universo, Ele também tem que ser responsável pelo mal. "Eu sou o Senhor e não há outro; além de Mim não há Deus (...) Eu formo a luz e crio as trevas, faço a paz e crio o mal. Eu, o Senhor, faço todas estas coisas" (Is 45:5 a 7).

Mas se o mal não é um princípio independente, e sim parte da Criação, sua existência também deve ter um sentido. Em outras palavras, qual o lugar das atrocidades nazistas na História guiada por Deus?

\footnotetext{
${ }^{538}$ Berkovits, 1973, pgs. 92 e 93

${ }^{539}$ Berkovits, God, Man... pgs. 75 e 76

${ }^{540}$ Berkovits, God, Man... pg. 76

${ }^{541}$ Berkovits, God, Man... pg. 76

${ }^{542}$ Berkovits, God, Man... pg. 77
} 


\section{5 - Por Causa de Nossos Pecados}

Para Berkovits, a idéia de que Deus puniu o povo judeu com o Holocausto devido a pecados cometidos é inconcebível ${ }^{543}$. Como judeu ortodoxo, o rabino não nega a possibilidade de Deus punir indivíduos ou mesmo todo um povo por suas más ações. Mas ele refuta esta situação no caso da Shoá. "Nem por um único momento devemos conceber a idéia de que o que aconteceu com o judaísmo europeu foi uma punição divina por quaisquer pecados cometidos por eles", escreve ${ }^{544}$.

Negando qualquer tipo de punição divina no Holocausto, Berkovits aceita apenas razões puramente humanas para explicar a perseguição contra os judeus ${ }^{545}$. Qualquer outra nação, afirma o rabino, vivendo sob as mesmas condições que os judeus - sem um refúgio seguro e sem instrumentos de poder para reagir às agressões - receberia o mesmo tratamento. Explicar a perseguição de outra maneira é "ingenuidade ou hipocrisia" 546 .

Berkovits considera o Holocausto como uma manifestação do colapso moral da humanidade, em particular da civilização ocidental ${ }^{547}$. "Como a história é, antes de mais nada, responsabilidade do homem (...) talvez ainda mais importante que a questão 'onde estava Deus', seja 'onde estava o homem”, escreve ${ }^{548}$.

\section{6 - $\underline{\text { Ocultamento da Face }}$}

Voltando, então, à questão: se o Holocausto não foi castigo divino, qual seu lugar na História guiada por Deus? Para Berkovits, a resposta está no conceito de Ocultamento da Face. A geração da Shoá sentiu que foi abandonada por Deus enquanto sofria em guetos e campos-de-concentração, da mesma maneira que gerações anteriores se sentiram desertadas pela divindade enquanto vivenciavam

\footnotetext{
${ }^{543}$ Berkovits, 1973, pg. 94.

${ }^{544}$ Berkovits, 1973, pg. 89.

${ }^{545}$ Berkovits, 1943, pgs. 128 a 130.

${ }^{546}$ Berkovits, 1943, pg. 129.

${ }^{547}$ Berkovits, 1973, pg. 36.

${ }^{548}$ Berkovits, 1973, pg. 7.
} 
outras catástrofes da história judaica. Por que isto acontece a pessoas religiosas, que cumprem os mandamentos, pergunta-se o rabino? ${ }^{549}$

Berkovits diferencia ${ }^{550}$ dois tipos de Ocultamento da Face: como punição divina contra pecados (ilustrado por Deuteronômio 31:17 e 18) ou como um fenômeno sem razão aparente (Salmo 44:18 a 25). No caso do Holocausto, como vimos, o pensador rejeitou a primeira possibilidade. O que aconteceu na Europa nazista foi Ocultamento da Face do segundo tipo, misterioso, onde os fiéis sentiram-se abandonados e sem entender a razão para tamanha destruição.

Berkovits aponta que o Ocultamento da Face sem justificativas já inquietava o judaísmo na época bíblica ${ }^{551}$. A Bíblia Hebraica reconheceu ${ }^{552}$ o problema e aceitou sua complexidade. Parte dos autores bíblicos sabia que nem todo acontecimento histórico poderia ser explicado apenas a partir de conceitos como "por causa de nossos pecados". Significamente, Isaías afirmou: "Seguramente Tu és um Deus que se mantém oculto, o Deus de Israel, Aquele que salva" (Is 45:15).

Berkovits interpreta ${ }^{553}$ esta passagem de Isaías como uma indicação de que o Ocultamento da Face é um atributo da própria natureza da divindade. O Deus de Israel tem como característica definidora o fato de se ocultar e, mesmo quando chamado pelo fiel num campo-de-concentração, ele poderá não responder. Mas não por indiferença, pois este mesmo Deus é a esperança do fiel, como afirma o mesmo livro profético: “Aguardo o Senhor que oculta Sua face à Casa de Jacó, eu espero por Ele" (Is 8:17). Como concluiu Berkovits, "de uma forma misteriosa, o Deus que se oculta é o Deus que salva", 554 .

\footnotetext{
${ }_{549}$ Berkovits, 1973, pgs. 98 e 99.

${ }^{550}$ Berkovits, 1973, pgs. 95 e 96.

${ }^{551}$ Berkovits cita o profeta Ezequiel, que notava como alguns judeus andavam na "escuridão" após a derrota para os babilônios em 586 a.e.c., dizendo "o Senhor não pode nos ver, o Senhor abandonou a terra" (Ez 8:12). Também o Segundo Isaías notava judeus exilados dizendo "o Senhor me abandonou, meu Senhor me esqueceu" (Is 49:14).

(Berkovits, 1973, pgs. 96 e 97).

${ }_{552}$ Berkovits, 1973, pg. 99.

${ }_{554}^{553}$ Berkovits, 1973, pg. 101.

${ }^{554}$ Berkovits mostra que também os rabinos da era talmúdica se preocuparam com o Ocultamento da Face sem razão aparente. No Talmud da Babilônia, Tratado Gitin 56b, uma explicação é oferecida para o silêncio divino frente ao sofrimento do inocente:

"Vespasiano enviou Tito [para destruir Jerusalém], que perguntou: Onde está o Deus deles, a rocha em quem confiam? (citação de Dt 32:37) Este era o perverso Tito, que blasfemou e insultou o Céu. O que
} 
Mas como, para Berkovits, um Deus que se oculta pode operar a salvação ?

\section{7 - Livre-Arbítrio}

Berkovits ${ }^{555}$ responde esta questão apresentando uma agadah talmúdica onde figuram o apóstata Elisha ben Avuyah ${ }^{556}$, alcunhado de Aher, e seu discípulo Rabi Meir. A passagem encontra-se no Talmud da Babilônia, Tratado Hagiga 15a:

Aher perguntou a Rabi Meir: Qual o significado do versículo 'Tanto uma como a outra, Deus as fez' (Ec 7:14) Ele (Meir) respondeu: 'Significa que para tudo o que o Santificado-Seja-Ele (Deus) fez, Ele também fez a contrapartida: para montanhas, Ele criou montes; para os mares, Ele criou rios'. Ele (Aher) disse: 'Rabi Akiva, seu mestre, não explicou desta maneira, mas sim que Ele criou justos e criou perversos, criou o paraíso e criou o inferno'.

$\mathrm{Na}$ interpretação de Berkovits para esta agadah, enquanto Rabi Meir entendeu a passagem de Eclesiastes como uma constatação sobre opostos materiais presentes no mundo, Ben Avuyah percebeu a dimensão ética da Criação: Deus criou o bem e o

ele fez ? Ele pegou uma prostituta pela mão e entrou no Santo dos Santos (no Templo de Jerusalém), abriu um rolo da Lei e cometeu um pecado (sexo ilícito) sobre ele. Ele então tomou uma espada e retalhou a cortina [sagrada] (...) Abba Hanan disse (interpretou o versículo): 'Quem é forte como tu, Senhor?' (Salmo 89:9) [como sendo] Quem é como Tu, poderoso em auto-contenção, pois ouviu as blasfêmias e insultos daquele homem perverso e permaneceu silencioso. Na Escola de Ishmael se ensinava (se interpretava o versículo): 'Quem é como Tu entre os deuses (אלים - Elim)' [Ex 15:11] [como sendo] Quem é como Tu entre os mudos ( אילמים - Ilemim)"

Ou seja, os rabinos do Talmud interpretaram como sinal do poder divino o Ocultamento da Face frente à profanação do Templo de Jerusalém, no ano 70. Deus é realmente poderoso, pois se conteve e não puniu o comandante romano Tito. Para Berkovits, os rabinos do Talmud notaram esta característica do Deus de Israel, que é ao mesmo tempo poderoso e silencioso (Berkovits, 1973, pgs. 93 e 94 ).

${ }^{555}$ Berkovits, 1973, pgs. 102 a 104

${ }^{556} \mathrm{O}$ apóstata Elisha ben Avuyah foi uma importante personalidade entre os sábios tanaim e seu comportamento intrigou as gerações seguintes, incluindo os amoraim, Maimônides e pensadores judeus modernos. Alcunhado de Aher (אחר, "outro", "diferente"), Ben Avuyah nasceu numa rica família de Jerusalém influenciada pelo helenismo. Provavelmente estudou tanto o judaísmo quanto a sabedoria grega, e primeiramente tornou-se um importante erudito e especialista na Lei judaica. O Talmud narra diferentes circunstâncias para a sua apostasia: atração pelo gnosticismo (doutrina greco-romana que via Deus afastado do mundo material, cujo governo seria feito por forças espirituais negativas), trauma pela violência da repressão romana após os levantes dos anos 70 e 135, entre outras. Convenceu-se que "não há julgamento nem juiz (divino)". Mesmo tendo deixado o judaísmo para trás, sua sabedoria continuou sendo apreciada por seu discípulo Rabi Meir, uma das figuras mais importantes do judaísmo rabínico. Alguns de seus ensinamentos sobreviveram na Mishnah, no tratado "Pirkei Avot" (Steinzaltz, 1997, pgs. 65 a 78). 
mal, o justo e o perverso. Inspirado por esta passagem talmúdica ${ }^{557}$, Berkovits afirma $^{558}$ que Deus criou duas possibilidades para o homem - ser justo ou ser perverso. Estas duas condições humanas são dependentes entre si: só é possível um indivíduo ser justo como resultado de uma escolha responsável, feita numa situação de liberdade, perante a alternativa de ser perverso. A menos que exista a possibilidade do indivíduo ser perverso, afirma o rabino, não poderá haver a possibilidade dele ser justo. "Onde não existe escolha, onde a possibilidade de ser perverso não está aberta ao homem, a possibilidade de se tornar justo também está excluída”, escreve.

Para Berkovits ${ }^{559}$, a liberdade de escolha e a responsabilidade individual são essências do ser humano e, sem estas, o homem não pode se definir como tal. É preciso permitir ao homem que faça suas escolhas em liberdade, do contrário ele cessa de existir. Por isso, Berkovits afirma que não é Deus quem faz o mal, Ele apenas criou a possibilidade do homem ser perverso.

A presença de justiça no mundo depende, assim, do livre-arbítrio humano ${ }^{560} \mathrm{e}$ nem o próprio Deus pode interferir na decisão de cada indivíduo entre o bem e o mal $^{561}$. Nem quando a opção humana pelo mal desagrada a Deus, pode haver intervenção divina nos assuntos mundanos. Se Deus interferisse, o mal seria exterminado, mas também a possibilidade do bem sumiria. $O$ homem pode ser amedrontado ou estimulado a fazer o bem, mas não pode ser ameaçado a fazer o bem. "Se Deus não respeitasse a liberdade de escolha do homem, não apenas o bem e o mal seriam abolidos da Terra, mas também o próprio ser humano desapareceria”, escreve.

No entanto, o homem com frequência usa a liberdade de escolha de maneira equivocada, decidindo pela alternativa errada ${ }^{562}$. E isto resulta que homens perversos fazem o inocente sofrer, como aconteceu no Holocausto. Mas, conforme Berkovits, se

\footnotetext{
${ }^{557}$ Braiterman, comentador da obra de Berkovits, chamou-o de "radical" por basear sua reflexão em Aher, afinal de contas, um personagem marginalizado no mundo talmúdico

${ }_{558}$ Berkovits, 1973, pg. 104

${ }^{559}$ Berkovits, 1973, pgs. 104 e 105.

${ }^{560}$ O comentarista da obra de Berkovits, Eliezer Schweid (1994, pgs. 349 e 350), afirma que esta ligação feita pelo rabino entre Ocultamento da Face e Livre-Arbítrio não encontra respaldo na tradição judaica. Segundo Schweid, não existe passagem da Bíblia Hebraica ou do Talmud que apóie a idéia de que, em nome do livre-arbítrio conferido também aos perversos, Deus tenha que permanecer distante e permitir que estes completem suas más intenções.

${ }_{561}$ Berkovits, 1973, pg. 105

${ }^{562}$ Berkovits, 1973, pgs. 105 e 106.
} 
questionarmos "por que há sofrimento imerecido", acabaremos nos perguntando "por que há homem", "por que há um mundo" e "por que houve a Criação". Isto, como afirma o rabino, é inútil, pois não adianta discutir com Deus sobre o por quê de ter criado o mundo. "Ele obviamente decidiu apostar no homem", escreve.

Berkovits cita Ezequiel 33:11 ("Eu (Deus) não tenho prazer na morte do perverso, mas sim que o perverso deixe seu mau caminho e viva") para afirmar que a divindade tem misericórdia do perverso e espera com paciência que ele retorne para o bom caminho. Agindo assim, contendo-se para não punir o perverso, Deus revela sua grandiosidade. Mas, ao tolerar o perverso, Deus também abandona a vítima e não responde aos seus apelos. "Esta é a tragédia fundamental da existência: a mesma misericórdia de Deus, Seu amor pelo homem, torna necessário o abandono de alguns homens a um destino que eles podem muito bem experimentar como indiferença divina à injustiça e ao sofrimento humano", escreve ${ }^{563}$.

O homem, deixado em liberdade absoluta, provavelmente terminará por se destruir ${ }^{564}$. Porém, Deus, o criador do homem, tem responsabilidade por sua criação e não pode deixar que isto aconteça. Por isso, Ele não pode se afastar inteiramente e "ocultar Sua face" totalmente da História. "Para que o homem seja, Deus precisa se ausentar, [mas] para que o homem não pereça no absurdo trágico de sua própria criação, Deus precisa continuar presente. O Deus da história precisa estar ausente e presente ao mesmo tempo", escreve.

Berkovits pergunta-se ${ }^{565}$ se todo este edificio teórico que construiu até este ponto, não poderia ser apenas uma hipótese, um mero exercício intelectual. Como provar que Deus atua nos assuntos humanos desta maneira - ao mesmo tempo ocultando-se e preocupando-se com os assuntos do mundo? Há algum indício na realidade humana que poderia provar isto?

\footnotetext{
${ }^{563}$ Berkovits, 1973, pg. 106

${ }^{564}$ Berkovits, 1973, pg. 107

${ }^{565}$ Berkovits, 1973, pg. 107.
} 
$8-\underline{\text { Aliança }}$

Sim, responde Berkovits, há uma prova de que toda esta teoria é verdadeira e o Deus que se oculta também está presente no mundo. Esta prova é a sobrevivência do povo judeu ${ }^{566}$. Foi por causa desta sobrevivência após o exílio na Babilônia que os profetas bíblicos puderam questionar a justiça divina e, ao mesmo tempo, continuar acreditando em Deus. Também foi devido à sobrevivência do povo judeu após a destruição de Jerusalém pelos romanos no ano 70, que os rabinos do Talmud falaram do silêncio de Deus, mas continuaram fiéis ${ }^{567}$. É também devido à sobrevivência do judaísmo após o Holocausto, que Berkovits afirma a continuidade de sua fé. Para o pensador, ao demonstrar um "poder de sobrevivência misterioso" 568, os judeus provam a existência de seu Deus. "Enquanto o judeu existir, ele é uma testemunha de que Deus existe", escreve ${ }^{569}$.

Berkovits cita Isaías 43:12 ("Vocês (Israel) são minha testemunha (...) e Eu sou Deus") para afirmar que a divindade precisa do povo judeu para testemunhar Sua presença na História ${ }^{570}$. Deus necessita exatamente de um povo pequeno e relativamente frágil como testemunha ${ }^{571}$. Se os judeus fossem um povo numeroso e naturalmente forte, sua sobrevivência seria uma consequência natural de uma posição hegemônica, e a presença do sobrenatural na História não poderia ser provada. Mas a sobrevivência de um povo frágil é a prova para os outros povos da presença de Deus

\footnotetext{
${ }_{566}^{566}$ Berkovits, 1973, pgs. 108 e.d e pg. 114.

567 Berkovits (1973, pgs. 107 e 108) cita a seguinte agadah do Talmud da Babilônia, Tratado Yoma $69 \mathrm{~b}$, que trata deste tema:

"Rabi Yehoshua ben Levi falou (perguntou): Por que aqueles homens eram chamados "Homens da Grande Assembléia" (Grande Assembléia = órgão máximo de decisão dos fariseus no período helenístico e, consequentemente, uma instituição venerada pelos rabinos do Talmud, continuadores do farisaísmo) ? Porque eles restauraram a coroa dos atributos divinos à sua completude antiga. [Pois] Moisés disse: O grande Deus, poderoso e terrível (Dt 10:17). Então (Mas) Jeremias veio e disse (baseado em Jr 32:17 a 25): Estrangeiros destróem Seu templo, onde estão seus terríveis feitos? Consequentemente ele (Jeremias) omitiu [o atributo] "terrível". Daniel veio e disse: Estrangeiros escravizam seus filhos, onde estão Seus feitos poderosos? Consequentemente ele (Daniel) omitiu [o atributo] "poderoso". Mas eles (Homens da Grande Assembléia) vieram e disseram: Ao contrário! Nisto estão Seus poderosos feitos, pois Ele suprime Sua fúria e tem tolerância com os perversos. Nisto estão Seus poderes terríveis: se não fosse pelo temor de Deus, como poderia uma nação (Israel) persistir entre as nações!"

${ }^{568}$ Berkovits, 1973, pg. 110.

${ }^{569}$ Berkovits, 1973, pg. 118.

${ }^{570}$ Berkovits, 1973, pgs. 114 e 115.

${ }^{571}$ Berkovits cita Deuteronômio 7:7 : "Se o Senhor se ligou a vós e vos escolheu não foi por serdes o mais numeroso dentre todos os povos, pois sois o menor de todos os povos".
} 
na História. "A relação de Deus com a história humana é tal que Ele precisa de um povo eleito", escreve ${ }^{572}$.

O fato da missão dos judeus como testemunhas de Deus ter sido anunciada por indivíduos da grandeza moral dos profetas, afirma Berkovits, é outro sinal de sua verdade ${ }^{573}$. Se os profetas, tidos como seres incorruptíveis, estivessem na realidade ludibriando sua audiência, teríamos então que concluir que não existe honestidade na face da Terra. E se eles próprios foram ludibriados a acreditar numa mentira, então teríamos que concluir que toda a condição humana é, essencialmente, uma ilusão.

O fato do "povo testemunha" ter sobrevivido por dois mil anos no exílio e ainda ter tido vitalidade para fundar um novo país no século XX é "um dos maiores milagres" 574 da história humana. Esta sobrevivência, na opinião de Berkovits ${ }^{575}$, é o "grande mistério da história mundial". A história dos judeus é um "segredo cerrado", que desafia interpretações naturalistas e testemunha uma dimensão supra-natural e fora-de-série na história do mundo. A trajetória de Israel, sendo uma história de fé, traz um elemento sobrenatural à história natural da humanidade.

Não foi à toa, afirma Berkovits ${ }^{576}$, que os judeus na Idade Média foram identificados como diabos e, na Idade Moderna, acusados de organizar uma conspiração secreta comandada por "sabios de Sião". "Isto reconhece o fato de que a sobrevivência de Israel nao é explicável em termos das dimensões históricas que os povos normalmente vivenciam", escreve.

Berkovits diferencia ${ }^{577}$ a história da humanidade da história dos judeus. A primeira é caracterizada por ser uma história política, de jogo de forças, marcada pela violência e materialismo. Já o povo judeu, especialmente durante os quase dois mil anos em que viveu sem um Estado independente, tem uma história marcada pelo heroísmo espiritual. É uma história com mensagem universal, sem vitórias ou derrotas

\footnotetext{
${ }^{572}$ Berkovits, 1973, pg. 115.

${ }^{573}$ Berkovits, God, Man... pgs. 25, 26 e 27.

${ }^{574}$ Berkovits, 1991, pg. 265.

${ }^{575}$ Berkovits, 1973, pgs. 111, 112 e 116.

${ }^{576}$ Berkovits, 1973, pg. 116.

${ }^{577}$ Berkovits, 1987, pgs. 44 e 46.
} 
materiais, mas de bravura idealista, de um povo que acreditou em seu destino e sobreviveu a todas as tentativas de aniquilação.

Dada a posição metafísica dos judeus no mundo, o Holocausto ${ }^{578}$ não poderia ser explicado apenas a partir de um ponto-de-vista racional-histórico, como mais um acontecimento na luta da humanidade contra o fascismo. A Shoá aconteceu, primordialmente, devido à posição cósmica dos judeus. Os nazistas perceberam esta posição crucial dos judeus no arranjo divino ${ }^{579}$ e criaram o Holocausto para “destronar Deus". O nazismo não foi uma ideologia política em sua essência, mas uma força espiritual negativa ${ }^{580}$. A brutalidade excepcional da Shoá mostrou que o que estava em jogo era algo "satânico, não humano, de um barbarismo metafísico",581.

Os nazistas pretenderam eliminar de uma vez por todas o Deus da História, que representava o oposto de sua ideologia supremacista. A Solução Final quis eliminar o povo-testemunha e, assim, eliminar Deus. A Alemanha nazista sentiu através de um "conhecimento sombrio" 582 a presença na História do Deus que se oculta. "O adversário natural deste tipo de rebelião é sempre o judeu, não pelo que ele faz, mas pelo que representa na história", escreve ${ }^{583}$.

Como consequência de sua posição como povo eleito de um Deus que se oculta na História e tem paciência com o perverso, esta nação carrega um peso ${ }^{584}$. Sofre, apesar de não ter culpa, como descreveu Isaías no célebre capítulo 53 ("o sofrimento vicário do servo de Deus"). Sofre não por seu próprio pecado, mas porque carrega os pecados das nações. Os judeus somente viverão em paz quando houver justiça no mundo e, segundo Berkovits, nos raros períodos em que houve maior justiça entre os povos, também houve menor sofrimento para os judeus. Assim, a história dos judeus está intimamente ligada à história da humanidade ${ }^{585}$. Durante a Segunda Guerra Mundial, a entrega dos judeus aos nazistas trouxe barbárie militar ao

\footnotetext{
${ }^{578}$ Berkovits, 1987, pg. 8.

${ }^{579}$ Berkovits, 1973, pgs. 117.

${ }^{580}$ Berkovits, With God..., pg. 81.

${ }^{581}$ Berkovits, 1973, pgs. 117 a 119.

${ }^{582}$ Berkovits, 1973, pg. 118.

${ }^{583}$ Berkovits, With God..., pg. 82.

${ }^{584}$ Berkovits, 1973, pg. 124 e 125.

${ }^{585}$ Berkovits, 1976, pg. 160.
} 
mundo. Após a fundação do Estado de Israel, novamente a entrega dos judeus "por um barril de petróleo (árabe)" faz o mundo se aproximar do "Armagedon termonuclear" 586 .

A "tragédia judaica" é apenas parte de uma tragédia maior, a do fracasso da justiça e da humanidade no mundo ${ }^{587}$. Neste sentido, a história dos judeus, diferentemente da história de qualquer outro povo, reflete a situação moral da humanidade ${ }^{588}$.

A íntima relação entre a história dos judeus e o destino da humanidade aparece também nas reflexões de Berkovits sobre o Exílio da nação judaica ${ }^{589}$. O conceito de Exílio é essencial para o judaísmo, mas deve ser examinado juntamente com o conceito de Redenção, aponta o rabino. As duas idéias - Exílio e Redenção acompanharam o judaísmo através de sua história ${ }^{590}$ : “A fé na redenção nos deu a força para resistir ao exílio", escreve ${ }^{591}$.

Berkovits diferencia dois tipos de Exílio: nacional e cósmico ${ }^{592}$. O exílio nacional começa com um hurban, uma destruição da soberania nacional seguida da dispersão do povo por terras estrangeiras. Já o exílio cósmico é mais fundamental e universal, indicando a condição humana em certo momento da História. É o exílio do propósito divino para a humanidade, quando o ser humano opta por objetivos egoístas

\footnotetext{
${ }^{586}$ Berkovits escreveu esta passagem em 1976, durante a Guerra Fria e a crise mundial do petróleo.

${ }^{587}$ Berkovits, 1943, pg. 131.

${ }^{588}$ Berkovits, 1973, pg. 86.

${ }^{589}$ Berkovits, 1976, pgs. 149, 150, 153.

${ }^{590}$ Berkovits cita (1976, pgs. 155 e 156) uma passagem talmúdica para afirmar que, ao aceitarem ser o povo eleito, os judeus passaram a viver entre o Exílio e a Redenção, entre o sofrimento e a garantia de sobrevivência. A passagem, encontrada no Talmud da Babilônia, Tratado Meguilá 6a, é interpretada por Berkovits como o entendimento do povo judeu de que deveria escolher entre se acomodar num mundo materialista (simbolizado pela cidade helenista Cesaréia) ou esperar pela promessa de um mundo espiritual (simbolizado por Jerusalém):

"Cesaréia e Jerusalém [são rivais]. Se alguém te disser que ambas foram destruídas, não acredite; se alguém disser que ambas estão florescendo, não acredite. [Mas] se disserem que Cesaréia está em ruínas e Jerusalém prospera ou que Jerusalém está deserta e Cesaréia floresce, você pode acreditar, como está escrito: 'Eu me tornarei rico, agora que ela está assolada' (Ezequiel 26:2). Se uma está rica, a outra está assolada; e se esta encontra-se enriquecida, a outra está assolada.”

${ }^{591}$ Berkovits, 1976, pg.150.

${ }^{592}$ Berkovits, 1976, pgs. 154, 155.
} 
como poder, dominação, posses e prazeres mundanos. O exílio cósmico continuará enquanto o plano de Deus para os homens permanecer irrealizado no mundo.

O exílio nacional do povo judeu coincide com o exílio cósmico ${ }^{593}$. Enquanto os judeus estão espalhados pelas nações, o próprio Deus vive uma situação similar, “como se" fosse um refugiado na Terra. Criou-se uma situação em que o destino de Deus na história humana está ligado ao destino dos judeus. "Ele precisa de nós não menos do que nós precisamos Dele", escreve ${ }^{594}$.

Os judeus buscam terminar o Exílio e chegar à Redenção de dupla maneira: através de sua redenção nacional e da redenção universal de todas as nações ${ }^{595}$. A separação entre estes dois níveis é impossível. Israel é um homeless num mundo onde o propósito de Deus para a humanidade também se encontra desabrigado ${ }^{596}$. Por isso, toda forma de redenção nacional judaica é também esperança para a humanidade.

A geração do Holocausto ${ }^{597}$ testemunhou o ápice do exílio cósmico, sua mais trágica intensificação na História. Como o exílio nacional judaico acompanha a intensidade do exílio cósmico, os judeus sofreram de maneira radical na Shoá. Durante a hegemonia do nazismo, a Redenção, que sempre acompanha o Exílio, pareceu ter se extinguido totalmente, e a fé judaica foi abalada em suas fundações.

Neste momento fatídico, apenas um remédio tão radical quanto a magnitude da Shoá poderia reverter esta tensa situação. Houve a necessidade de "[uma] redenção nacional à vista de todos os homens, através da restauração da soberania [judaica] na terra de Israel” 598 . A Providência Divina não teve outra alternativa a não ser conceder aos judeus uma medida de redenção nacional para contrabalancear a destruição nacional.

\footnotetext{
$\overline{{ }^{593} \text { Berkovits, 1976, pgs. } 155 \text { e } 156 .}$

${ }^{594}$ Berkovits, 1976, pg. 160.

${ }^{595}$ Berkovits, 1976, pgs. 157 e 158.

${ }^{596}$ Berkovits, God, Man..., pg. 142.

${ }^{597}$ Berkovits, 1976, pgs. 158, 159

${ }^{598}$ Berkovits, 1976, pg. 159.
} 


\section{9 - $\underline{\text { Significado Religioso do Estado de Israel }}$}

Consequentemente, Berkovits discorda do sionismo que defende a criação de um Estado destinado a "normalizar" a vida judaica e transformar a população exilada numa "nação como as demais". Para o pensador, isto é um erro de percurso. O Estado de Israel não pode se "normalizar" e entrar na história das demais nações ${ }^{599}$.

Com a proclamação do Estado de Israel em 1948, afirma Berkovits, os judeus não passaram a viver uma nova história, mas sim a mesma antiga história de “heroísmo da fé e crença nos valores do espírito". Não houve normalização, apenas o início de uma nova fase de uma mesma história diferenciada, quando comparada com a de outros povos ${ }^{600}$.

Prova disto, afirma Berkovits ${ }^{601}$, é o fato do Estado judeu não ter sido criado por um processo "natural", similar a outros episódios contemporâneos de nacionalismo, mas sim por um caminho fora da "normalidade". Berkovits vê a "mão da Divina Providência" na fundação do Estado judeu, especialmente porque era exatamente isto que o povo judeu necessitava para sobreviver após o Holocausto.

Outra mostra da presença do sobrenatural na criação do Estado de Israel é que o retorno dos judeus à sua terra sempre foi uma idéia absurda, que não seguia a lógica dos demais povos ${ }^{602}$. No contexto da história mundial, a crença judaica de que haveria um retorno à terra ancestral após dois mil anos de exílio e perseguições não encontra nenhum apoio na experiência humana. A partir da vivência dos demais povos, esta volta não seria possível e a fé no fim do exílio, um contrasenso ${ }^{603}$.

Berkovits interpreta a sobrevivência dos judeus após o Holocausto, corporificada no Estado de Israel, da mesma maneira como os profetas interpretaram a sobrevivência após o exílio babilônico, e os rabinos do Talmud a interpretaram após

\footnotetext{
${ }^{599}$ Berkovits, 1987, pgs. 46 e 47.

${ }^{600}$ Berkovits, 1987, pg. 47.

${ }^{601}$ Berkovits, 1987, pg. 47 / Berkovits, 1973, pg. 134.

${ }^{602}$ Berkovits, 1987, pg. 47.

${ }^{603}$ Berkovits, 1991, pg. 265.
} 
a destruição do Templo de Jerusalém. Ou seja, como uma mostra da continuidade da missão judaica como povo testemunha ${ }^{604}$.

A fundação do Estado judeu também representou a "abertura dos portões para a redenção final" ${ }^{605}$. O processo messiânico para a salvação universal começou com este retorno dos judeus à sua terra ancestral ${ }^{606}$, pois, segundo o rabino, todos os profetas bíblicos que se pronunciaram sobre a redenção, viram-na materializar-se paralelamente à volta dos judeus ao Oriente Médio.

Para Berkovits ${ }^{607}$, a criação do Estado de Israel também carrega a função religiosa de justificar o longo sofrimento dos judeus durante os séculos de exílio. Sem um retorno a Sião e a perspectiva de redenção, o judaísmo seria reduzido a uma fé de caráter individual, que não interfere na vida pública. Neste caso, não se justificaria as perseguições e humilhações sofridas no exílio e toda a experiência judaica seria reduzida a um “episódio deplorável (...) que quanto mais rápido for esquecido, melhor para todos" 608 .

Mas ao conceder valor religioso ao Estado de Israel, Berkovits vê-se obrigado a responder questões sensíveis: Como interpretar as guerras com os vizinhos árabes? Como explicar o forte secularismo dos israelenses, mesmo após o "início da redenção"?

Quanto aos conflitos militares de Israel, Berkovits concentra-se especialmente na Guerra dos Seis Dias, em 1967, que se desenrolava enquanto escrevia sua obra Faith after the Holocaust. Para o rabino, este conflito foi mais um episódio da Revelação divina. Ele descreve a sensação que tomou conta de judeus ao redor do mundo durante o desenrolar da guerra, ao testemunharem algo "além das fronteiras do

\footnotetext{
${ }^{604}$ Berkovits, 1973, pg. 111.

${ }^{605}$ Berkovits, 1991, pg. 264.

${ }^{606}$ Berkovits, 1973, pgs. 145 e 146.

${ }^{607}$ Berkovits, 1973, pg. 152.

${ }^{608}$ Berkovits enfatiza ainda uma outra função religiosa do Estado de Israel. É o fato da soberania política permitir aos judeus cumprirem um maior número de mandamentos religiosos e, assim, observarem sua religião em plenitude. Para o rabino, somente numa situação política em que os judeus são responsáveis pelo controle da vida pública e têm liberdade plena de ação é que os mandamentos podem ser observados com maior rigor.

(Berkovits, 1973, pg. 150 / Berkovits, 1987, pg. 7 / Berkovits, God, Man..., pg. 135)
} 
tempo (...) uma experiência espontânea (...) com o poder de uma inescapável qualidade de revelação" ${ }^{609}$.

Para Berkovits, a Guerra dos Seis Dias foi um "momento de história messiânica" ${ }^{610}$, uma intervenção de Deus nos acontecimentos humanos, pois esta vitória militar não pode ser explicada apenas em termos de superioridade de forças bélicas. O fato do exército israelense ter obtido uma vitória de forma tão repentina foi um sinal, um momento da história judaica que pode ser equiparado aos triunfos militares descritos na Bíblia Hebraica. "O que aconteceu não foi desejado, e veio sobre nós como uma precipitação dramática”, escreve.

Nestes acontecimentos, especialmente na conquista de toda a cidade de Jerusalém, Berkovits percebeu "um sorriso na face de Deus", um momento messiânico que serviu para reenergizar o povo judeu. ${ }^{611}$. Esta vitória militar assinalou um novo começo para o judaísmo, que vivia uma difícil situação espiritual após o Holocausto. Berkovits compara a renovação espiritual trazida pela Guerra dos Seis Dias ao surgimento das sinagogas após a destruição do Primeiro Templo de Jerusalém e ao surgimento do judaísmo rabínico após a destruição do Segundo Templo. "No passado, após cada hurban, construímos algo novo e diferente. Após cada destruição, fomos guiados a novos desenvolvimentos na história do judaísmo (...) Tendo [agora] achado nosso caminho de volta a Sião num momento messiânico, sabemos que Deus está fazendo algo novo", escreve.

Berkovits também entendeu o fortalecimento político-territorial do Estado de Israel após a vitória militar de 1967 - a conquista da Cisjordânia, Gaza, Colinas do Golã e Deserto do Sinai - como a consolidação de um espaço para o judaísmo florescer ${ }^{612}$. Segundo o rabino, no início do exílio, o judaísmo pôde sobreviver razoavelmente confortável em locais como a Babilônia, onde os judeus se autogovernavam segundo suas leis religiosas. Mas durante a Idade Média, este espaço diminuiu, com o judaísmo podendo exprimir-se apenas no interior dos guetos europeus. Nos tempos modernos, com a Emancipação dos judeus e a assimilação na

\footnotetext{
${ }^{609}$ Berkovits, 1973, pg. 145.

${ }^{610}$ Berkovits, 1973, pgs. 153 e 154.

${ }^{611}$ Berkovits, 1973, pgs. 156 e 157.

${ }^{612}$ Berkovits, 1973, pgs. 157 e 158.
} 
cultura européia, acentuou-se ainda mais o desaparecimento de uma base física para o judaísmo. Este processo tornou-se crítico com a destruição nazista dos centros culturais judaicos na Europa. Já a criação do Estado de Israel e, em particular, a Guerra dos Seis Dias proporcionaram um alargamento de espaço para o judaísmo florescer $^{613}$.

Num escrito posterior, de 1976, Berkovits parece ter perdido parte do entusiasmo em relação ao caráter messiânico do Estado de Israel. O pano-de-fundo desta reflexão é a Guerra do Yom Kipur (1973) e suas consequências. Sabe-se que o ataque-surpresa das forças árabes e as pesadas baixas israelenses reavivaram o sentimento de insegurança no país. Também, os territórios conquistados durante a Guerra de 1967, incluindo a região leste de Jerusalém, já se mostravam um fardo difícil de carregar dez anos mais tarde.

Berkovits, em 1976, confessa, com pesar, que "até aqui, o Estado de Israel se encontra longe de ser o centro espiritual do povo judeu que se esperava" ${ }^{614}$. O problema, escreve, é a opção da sociedade israelense pelo secularismo e materialismo. Ao se afastar dos ideais messiânicos e pretender ser "uma nação entre as demais", o país perde seu especial significado e revela-se apenas como uma nação pequena, provinciana e insignificante no contexto internacional ${ }^{615}$. "O sionismo tentou substituir o messianismo (...), [mas o] sionismo apenas se justifica como um instrumento do messianismo judaico", afirma, desencantado ${ }^{616}$.

\footnotetext{
${ }^{613}$ Mesmo o isolamento do Estado de Israel no cenário internacional é interpretado por Berkovits de forma religiosa. Deixando de lado explicações geopolíticas, o rabino entende este fato como sendo o mesmo isolamento vivido pelos judeus através de sua história. Para ele, este isolamento é um distanciamento do jogo político das demais nações, de uma "história de poder", enquanto Israel vive solitário sua "história de fé". Ao viverem isolados, Israel e os judeus correm perigo, mas ao mesmo tempo deixam claro sua condição de "barômetro moral do mundo", indicando, através de sua trajetória histórica, a situação espiritual de toda a humanidade.

(Berkovits, 1973, pgs. 164, 166 e 167)

${ }^{614}$ Berkovits, 1976, pg. 132.

${ }^{615}$ Berkovits, 1976, pg. 135

${ }^{616}$ Berkovits, 1976, pgs. 138 e 139.
} 


\section{7 - O HOLOCAUSTO NO PENSAMENTO DE IRVING GREENBERG}

\section{1 - Biografia}

Irving Greenberg nasceu em Nova York, em 1933, numa família de imigrantes judeus europeus que seguiam a Ortodoxia Moderna. Parentes seus que permaneceram na Europa foram assassinados no Holocausto. Greenberg formou-se rabino com 20 anos de idade e doutorou-se em História pela Harvard University. É considerado um dos introdutores da disciplina Estudos do Holocausto nas universidades norteamericanas ${ }^{617}$.

Além de exercer o rabinato, Greenberg foi professor na Yeshiva University e City University (Nova York). Em 1978, chefiou a Comissão Presidencial sobre o Holocausto, organizada a pedido de Jimmy Carter. Foi um dos fundadores do museu United States Holocaust Memorial (Washington) e presidiu esta instituição no período 2000-2002. Destacou-se também no diálogo inter-confessional em seu país.

$\underline{\text { Obra }}$

Greenberg é um homem de ação, responsável pela criação de importantes instituições tanto no interior da comunidade judaica quanto a nível nacional nos EUA. O resultado de seu intenso ativismo é que boa parte de seu pensamento está expresso em artigos e ensaios, e não condensado em livros mais longos ${ }^{618}$. A Teologia do Holocausto, que ocupa um lugar central em sua reflexão, está espalhada em vários trabalhos curtos, que precisam ser reagrupados para se chegar a um quadro geral sobre seu pensamento.

Greenberg expressou suas principais idéias sobre o Holocausto nos ensaios $\underline{\text { Voluntary Covenant e Cloud of Smoke, Pillar of Fire. Quanto a livros, em seu The }}$

\footnotetext{
${ }^{617}$ Singer, 1989, pg. 42 / Rosenberg, 1982, pg. 227 / Katz, 1993, pgs. 59 a 62 / Belitsky, 2001, pgs. 42 e 43 / "N.Y. Rabbi to Chair Holocaust Museum" in The Washington Post (online), 16/02/2000 (http://www.washingtonpost.com/wp-srv/Wplate/2000-02/16/1531-021600-idx.html); e informações cedidas por Greenberg ao autor.

${ }^{618}$ Ele próprio descreveu como compromissos comunitários o impediram de escrever um planejado livro (Greenberg, 1998, pgs. xiii a xv).
} 
Jewish Way - Living the Holidays, Greenberg dedica um capítulo à Shoá e, em Living in the Image of God, uma longa entrevista concedida pelo pensador, há também reflexões sobre o tema.

Além do Holocausto, Greenberg ${ }^{619}$ refletiu sobre uma variedade de outros assuntos, incluindo crítica bíblica, halakhah, educação, relação entre ortodoxos e outras correntes do judaísmo, problemas políticos do Estado de Israel e diálogo entre judeus e cristãos.

O fato de Greenberg ter expressado suas idéias de forma dispersa não diminui a importância de sua reflexão, considerada uma das mais importantes realizadas dentro do judaísmo a respeito do Holocausto. Característica de sua obra é a coragem de propôr idéias totalmente novas, que muitas vezes o coloca numa posição de estranhamento em relação ao establishment da Ortodoxia Moderna.

Para Michael Morgan, Greenberg é um pensador "iconoclasta" ${ }^{620}$, "corajoso e radical" ${ }^{621}$, que fez uma reflexão "importante" ${ }^{622}$. Segundo Steven Katz, nenhum outro pensador teve um impacto tão decisivo na comunidade judaica dos EUA nos últimos anos, tanto devido à sua reflexão quanto à sua atividade comunitária ${ }^{623}$.

Para Katz ${ }^{624}$, em qualquer debate sobre a viabilidade da crença no judaísmo após o Holocausto, é necessário considerar com "seriedade" a reflexão de Greenberg. Isto apesar de que, em sua opinião, Greenberg não chegou a alcançar uma "explicação precisa e completa" da situação do judaísmo no pós-Shoá.

\section{$\underline{\text { O Holocausto no pensamento de Greenberg }}$}

\section{1 - $\underline{\text { Singularidade do Holocausto }}$}

\footnotetext{
${ }^{619}$ Singer, 1970, pg. 74.

${ }^{620}$ Morgan, 2001, pg. 135.

${ }^{621}$ Morgan, 2001, pg. 121.

${ }^{622}$ Morgan, 1992, pg. 99.

${ }^{623}$ Katz, S., 1993, pg. 59.

${ }^{624}$ Katz, S., 1993, pgs. 83 e 84.
} 
Para Greenberg, o Holocausto foi a maior e inigualável catástrofe da história judaica ${ }^{625}$. Este evento foi único ${ }^{626}$, evidenciado pela extensão da destruição, pela negação aos judeus do direito de existir e pela pretensão do nazismo em se deificar. Também único no caso do Holocausto foi o desejo do algoz de destruir a sacralidade de toda uma religião ${ }^{627}$.

Como consequência da singularidade do Holocausto, é inadequado tentar entendê-lo completamente através de categorias teológicas do passado ${ }^{628}$. A singularidade da Shoá determina que também as respostas conceituais para este evento sejam singulares. Daí Greenberg rejeitar propostas de pensadores do Holocausto que se baseiam em categorias clássicas, tanto ateístas (Richard Rubenstein ${ }^{629}$ ) quanto teístas (Eliezer Berkovits e Emil Fackenheim ${ }^{630}$ ). Segundo o rabino norte-americano, nenhuma dessas posições fornece uma resposta à altura da "presença de crianças queimadas" 631.

Um evento singular demanda uma atitude singular: o judaísmo deve passar por uma reformulação drástica para que possa continuar existindo, afirma Greenberg ${ }^{632}$. Esta religião já havia passado por uma profunda transformação após a destruição do Segundo Templo de Jerusalém, quando surgiram como consequência o rabinismo e o Talmud. Agora, após a destruição do século XX e com o judaísmo passando por uma nova mudança política (a criação do Estado de Israel), uma nova transformação radical faz-se necessária ${ }^{633}$.

Esta transformação ainda está em formação e pode ser apenas vislumbrada ${ }^{634}$. Para Greenberg, a halakhah terá que sofrer transformações, sob o impacto do

\footnotetext{
${ }^{625}$ Greenberg, 1978, pg. 155; Greenberg, 1979, pg. 71.

${ }^{626} \mathrm{Na}$ entrevista ao autor desta tese (ver Apêndice), Greenberg considerou a Shoá um acontecimento "único e não-único ao mesmo tempo".

${ }^{627}$ Greenberg nota que os nazistas escolhiam propositalmente as festividades judaicas para realizar seleções de vítimas, emitir decretos mórbidos e organizar deportações para campos-de-concentração. Por exemplo, o Gueto de Varsóvia foi fechado no Yom Kipur de 1940, deportações em massa da capital polonesa começaram no Tisha Be-Av de 1942 e a destruição deste gueto foi programada para o Pessach de 1943 (Greenberg, 1993, pgs. 90 e 91).

${ }^{628}$ Greenberg, 1979, pg. 71.

${ }^{629}$ Sobre Rubenstein, ver capítulo "A Teologia do Holocausto - Uma Introdução".

${ }^{630}$ Sobre Fackenheim, ver capítulo "A Teologia do Holocausto - Uma Introdução".

${ }^{631}$ Greenberg, 1977, pg. 26.

${ }^{632}$ Greenberg, 1978, pgs. 156 e 158.

${ }^{633}$ Greenberg, 1978, pg. 158.

${ }^{634}$ Greenberg, 1978, pg. 158.
} 
Holocausto. A ausência de intervenção divina durante o massacre evidenciou uma mudança de atitude por parte de Deus. Como consequência, também os judeus precisam mudar sua atitude. "Decidir questões através da lei judaica da mesma maneira [que antes da Shoá] seria assumir que Deus intervém do mesmo modo que anteriormente", escreve ${ }^{635}$.

Para Greenberg, é digno de nota que o Estado de Israel tem até hoje dificuldade em definir "quem é judeu" ${ }^{636}$. Uma definição universalmente aceita sobre esta questão, aponta o rabino, somente será possível quando a própria halakhah se transformar para incluir novos significados do judaísmo surgidos com o Holocausto. Isto acontecerá “apenas quando acontecer uma redefinição da halakhah, que leve em consideração o risco e o sacrifício de ser judeu, o qual o Holocausto (...) mostrou ser implícito ao simples existir como judeu" ${ }^{637}$.

Outra mudança necessária ${ }^{638}$ no judaísmo diz respeito às orações a Deus. Após o Holocausto, as rezas precisam expressar a "raiva" do judeu despertada pela sensação de abandono durante o massacre nazista ${ }^{639}$. Para Greenberg, as rezas tradicionais são "banais" e novas preces serão necessárias para "responsabilizar Deus". Deste modo, expressando sua raiva e contrariedade, os judeus poderão estabelecer um novo e único tipo possível de relacionamento com a divindade. "A raiva é mais compatível com amor e envolvimento, do que delicadezas agradáveis e velhos cumprimentos".

A própria fé absoluta em Deus precisa ser revista, como efeito do Holocausto ${ }^{640}$. Para Greenberg, após a destruição nazista, acabou a dicotomia rígida

\footnotetext{
${ }^{635}$ Greenberg, 1978, pgs. 160 e 161.

${ }^{636}$ A questão tem grande importância em Israel, pois a legislação do país ("Lei do Retorno") garante a todo judeu direito automático à cidadania.

${ }^{637}$ Greenberg, 1978, pg. 161.

${ }^{638}$ Greenberg, 1977, pgs. 39 e 40.

${ }^{639}$ Para Greenberg, um bom modelo para novas orações é o capítulo 3 do livro bíblico Lamentações, em especial as seguintes passagens, que ele interpreta como sendo a expressão do indivíduo sem pecados que vive uma aflição infligida por Deus:

"Eu sou o homem que viu a aflição ( Lm 3:1) (...) [Deus] fez envelhecer minha carne e minha pele (Lm 3:4) (...) Ele [Deus] é como um urso à espreita, como um leão de emboscada [contra mim] (Lm 3:10) (...) Então eu disse: já pereceu minha glória, como também a minha esperança no Senhor (Lm 3:18).” (as complementações entre colchetes são de Greenberg)

(Greenberg, 1977, pgs. 39 e 40)

${ }^{640}$ Greenberg, 1977, pgs. 27 e 28.
} 
entre ateísmo e crença em Deus. Agora, a fé na presença divina "vai-e-volta" e a diferença entre o cético e o crente está apenas na "frequência" dos momentos de fé. Após o Holocasto, haverá momentos em que a fé superará a lembrança das "crianças assassinadas". Em outros, será obliterada. Portanto, a fé na Providência Divina balançará entre o "Êxodo e [o campo-de-concentração] Buchenwald”, numa situação que o pensador norte-americano chama de "dialética".

A transformação do judaísmo ocasionada pelo Holocausto será um processo longo e demorado ${ }^{641}$. Para Greenberg, a tendência natural humana é sempre manter o já-conhecido e negar uma Revelação divina que possa mudar o rumo de toda uma religião. Portanto, será necessário o surgimento de uma nova e "extraordinária" liderança espiritual para reestruturar a tradição e garantir um novo florescimento do judaísmo. Para Greenberg, este deverá ser um "processo doloroso e altamente conflituoso".

\section{2 - Por Causa de Nossos Pecados}

Greenberg rejeita radicalmente a idéia de que o Holocausto tenha sido punição divina por pecados do povo judeu. Para o rabino, aplicar este conceito neste caso seria “demoníaco" ${ }^{642}$. "Diga às crianças nas covas que elas estão sendo queimadas por causa de seus pecados. Uma pessoa honesta - ou melhor, uma pessoa decente cuspiria num tal deus antes de aceitar este argumento, se este fosse verdadeiro", afirma ${ }^{643}$.

Insistir nesta explicação seria trair o sofrimento das vitímas ${ }^{644}$. "Depois que elas foram cruelmente torturadas e assassinadas, transformadas em sabão, seus

\footnotetext{
${ }^{641}$ Greenberg, 1977, pg. 24.

${ }^{642}$ Greenberg, 1977, pgs. 25 e 26.

${ }^{643}$ Greenberg, 1977, pg. 34.

${ }^{644}$ Greenberg apresenta uma passagem do Talmud da Babilônia, Tratado Baba Metzia 58b, para corroborar sua posição:

"Nossos rabinos ensinaram que [quanto ao versículo Lv 25:17] "Não explore seu compatriota", a Bíblia está se referindo a ofensas verbais. [Por exemplo,] se um homem é um penitente, não se deve dizer a ele 'lembre-se de suas ações passadas'. (...) Se [uma pessoa] está sofrendo ou foi afligida por uma doença ou enterrou seus filhos, não se deve falar com ela como fizeram os companheiros a Jó.”
} 
cabelos utilizados em travesseiros e seus ossos, em fertilizantes (...) o teólogo infligiria nelas a última indignidade que resta: insistir que tudo isto aconteceu devido a seus pecados" 645 .

\section{3 - $\underline{\text { História como Revelação Divina }}$}

A História parece mostrar que não há possibilidade de redenção para o ser humano, afirma Greenberg ${ }^{646}$. A vasta maioria da humanidade sempre viveu em situação de pobreza, opressão e anonimato. Também os ricos e poderosos, assim como os indivíduos criativos, sofrem e passam por tragédias em suas vidas, e finalmente morrem. A História parece indicar que a vida humana tem pouco valor.

Já o judaísmo ${ }^{647}$ afirma o oposto: há um Deus que se preocupa com a humanidade e o ser humano tem grande importância. Judaísmo é uma religião de redenção, afirma Greenberg, portanto promete salvação para a humanidade durante a história concreta. Num certo momento futuro, a humanidade chegará à perfeição. "Não haverá mais opressão nem exploração (...) até a doença e a morte serão superadas", escreve o rabino ${ }^{648}$.

A chave ${ }^{649}$ para se interpretar eventos históricos dentro do processo de redenção é julgá-los a partir do acontecimento central do judaísmo, o Êxodo, ou seja, a libertação dos escravos hebreus do Egito. Este evento tornou-se normativo na religião judaica, uma "experiência orientadora" a partir da qual se compreende todos os demais acontecimentos históricos. O significado do Êxodo foi mostrar que há um Deus interessado nos assuntos mundanos (a divindade interessou-se pelos escravos israelitas) e que o ser humano foi criado para viver em liberdade (a divindade libertou os israelitas do jugo egípcio).

\footnotetext{
${ }^{645}$ Greenberg, 1977, pg. 25.

${ }^{646}$ Greenberg, 1978, pg. 139.

${ }^{647}$ Greenberg, 1977, pgs. 7 e 8.

${ }^{648}$ Greenberg, 1981, pg. 1.

${ }^{649}$ Greenberg, 1978, pg. 140; Greenberg, "Religious Values...”, pg. 64.
} 
Para Greenberg, o Êxodo ocorreu para lembrar a humanidade de sua condição original, no Jardim do Éden, em estado de perfeição. O ser humano foi criado desta maneira para que nunca se esquecesse deste ideal paradisíaco e nunca se contentasse com algo menor. O Êxodo aconteceu na História para evitar que a humanidade se reconciliasse com o mal que existe no mundo e não aceitasse um estado menor que a perfeição ${ }^{650}$.

O Êxodo ${ }^{651}$, porém, é um modelo ainda não-realizado. Apesar de ter demonstrado que há uma alternativa para o estado atual da humanidade, não eliminou o mal, nem mudou o status quo do mundo. O significado do Êxodo, em sua plenitude, será realizado apenas no futuro, durante a própria História, quando seus valores forem universalizados e toda a humanidade entrar na era messiânica.

O povo judeu ${ }^{652}$ testemunhou o Êxodo e, assim, tornou-se testemunha perante todo o restante da humanidade de um futuro de esperança. Os judeus experimentaram naquele momento a possibilidade de redenção e, a partir de então, transmitem esta mensagem aos demais povos. Mas, neste papel de testemunhas, a credibilidade dos judeus está sujeita aos eventos que os afeta. Acontecimentos históricos podem sublinhar a verdade da mensagem do Êxodo ou podem colocá-la em dúvida.

Todo grande hurban ${ }^{653}$ golpeia a credibilidade da mensagem do Êxodo. Derrotas do povo judeu atacam toda a estrutura da missão de testemunha e a torna menos crível perante o mundo. Além disso, a auto-capacidade e o desejo de testemunhar do povo judeu são minados a cada grande hurban. Não é à toa que todo grande hurban marca uma época de crise e transformação no judaísmo: os pensadores judeus precisam reconciliar a tragédia com a redenção prometida pelo Êxodo, para seguir adiante na missão de testemunhas.

O primeiro grande hurban ${ }^{654}$ - a destruição do Templo de Jerusalém pelos babilônios - foi um destes grandes eventos que ameaçaram a estrutura do judaísmo. $\mathrm{O}$

\footnotetext{
${ }^{650}$ Greenberg, 1978, pg. 141.

${ }^{651}$ Greenberg, 1978, pgs. 140 e 141; Greenberg, 1977, pg. 8; Greenberg, 1981, pg.1.

${ }^{652}$ Greenberg, 1978, pgs. 141 e 142.

${ }^{653}$ Greenberg, 1978, pg. 145.

${ }^{654}$ Greenberg, 1978, pgs. 145 e 146; Greenberg, 1993, pg. 82.
} 
santuário, visto como a morada da presença divina, foi eliminado, criando uma situação que parecia inconciliável com a doutrina judaica da época. A crise só foi superada pela mensagem dos profetas, que interpretaram a destruição como sendo uma punição de Deus pelos pecados do povo. Ao propor esta explicação, os profetas também estavam reafirmando a preocupação da divindade pelos assuntos mundanos (se Deus não se preocupasse com os judeus, não os puniria). Os judeus aceitaram esta explicação e tornaram-se até mais fiéis a seu Deus do que foram antes do hurban.

O segundo grande hurban ${ }^{655}$ - a destruição do Segundo Templo pelos romanos - voltou a ameaçar o judaísmo. Novamente, o centro religioso desapareceu e iniciou-se um doloroso exílio político. Desta vez, foi a classe rabínica emergente que teve o papel de superar a crise. Como os profetas, os rabinos também utilizaram o conceito "por causa de nossos pecados" para explicar o hurban.

Porém, os rabinos também frisaram ${ }^{656}$ um outro conceito explicativo, o Ocultamento da Face. Eles afirmaram que, a partir deste segundo hurban, Deus ocultaria sua presença dos seres humanos e não mais enviaria mensagens explícitas através de profetas. Como consequência da maior ausência de Revelação divina direta, os judeus deveriam assumir maiores responsabilidades. Dali em diante, desenvolveriam eles mesmos leis (halakhot), seguindo a opinião majoritária dos líderes da comunidade, os rabinos.

No século XX, o povo judeu ${ }^{657}$ viveu o maior hurban de sua história, o Holocausto. O nazismo representou um ataque maciço contra a fé na mensagem do Exxodo. Abriu-se uma nova crise espiritual, que ainda não foi superada. Por isso, uma nova reformulação do judaísmo deve acontecer no futuro para que os fiéis possam continuar seguindo em sua missão de testemunhas. "Esta é uma era de dores do parto - um desses raros períodos em que uma grande metamorfose do judaísmo está prestes a ocorrer", afirma Greenberg ${ }^{658}$.

\footnotetext{
${ }^{655}$ Greenberg, 1978, pgs. 146 e 147; Greenberg, 1993, pg. 84.

${ }^{656}$ Greenberg, 1978, pgs. 146 e 147; Greenberg, 1993, pg. 84.

${ }^{657}$ Greenberg, 1978, pgs. 155 e 156; Greenberg, "Religious Values...", pg. 71.

${ }^{658}$ Greenberg, 1978, pg. 158.
} 
4 - $\underline{\text { Aliança }}$

Para Greenberg, um dos elementos centrais do judaísmo que precisam ser reformulados sob o impacto do Holocausto é o conceito de Povo Eleito. O rabino entende ${ }^{659}$ a Aliança de Deus com Israel como um pacto onde a divindade garante a sobrevivência dos judeus, enquanto estes cumprirem a missão de testemunhas. Porém, durante a perseguição nazista, com a ameaça de extermínio completo do povo judeu, pareceu que a garantia divina não estava mais ativa.

Para explicar sua visão da transformação da Aliança, Greenberg divide a história judaica em três grandes épocas: a Era Bíblica (do Gênesis à destruição do Segundo Templo de Jerusalém), a Era Rabínica (do início do Exílio até a Shoá) e a Era Pós-Holocausto ${ }^{660}$.

$\mathrm{Na}$ Era Bíblica, afirma Greenberg, a Aliança de Deus com os judeus era “involuntária”. Isto porque o Pacto bíblico, que continua existindo até hoje, deveria ser marcado no corpo dos judeus, através da circuncisão ordenada a Abraão e seus descendentes. Toda criança judia recebe até nossos dias este "selo", numa idade em que não tem a possibilidade de decidir livremente se deseja ou não aceitar a Aliança $^{661}$.

Mesmo o judeu que deseja negar ou se desviar da Aliança, carrega involuntariamente em seu corpo esta marca. A circuncisão é a maior prevenção contra a assimilação dos judeus, impossibilitando que ele "passe como se não fosse um [membro] da Aliança" 662 .

Além de ser forçada em idade precoce, a Aliança bíblica traz outra característica que sublinha seu caráter "involuntário". O Pacto foi apresentado aos judeus nos primórdios de sua história, e estes a aceitaram desconhecendo o fardo que seria carregá-lo através dos tempos ${ }^{663}$.

\footnotetext{
${ }^{659}$ Greenberg, 1993, pg. 79.

${ }^{660}$ Greenberg, 1981, pg. 3 e.d.

${ }^{661}$ Greenberg, 1993, pg. 80.

${ }^{662}$ Greenberg, 1993, pgs. 80 e 81.

${ }^{663}$ Greenberg, 1988, pg. 320.
} 
Já na Era Rabínica ${ }^{664}$, continua Greenberg, os rabinos concluíram que Deus, como um mestre-pedagogo, quis elevar os judeus a um novo patamar na Aliança. Enquanto a divindade se afastaria dos assuntos mundanos, “ocultando Sua face”, os judeus seriam chamados a uma participação mais ativa. Isto representou uma profunda alteração na Aliança, com os judeus tornando-se um parceiro mais maduro no relacionamento com a divindade. A palavra "parceria" (em hebraico, shutafut ou שותפות), ausente na Bíblia Hebraica, tornou-se recorrente na literatura rabínica, nota o rabino ${ }^{665}$.

Para dar conta da maior ausência do parceiro divino na Aliança, os rabinos tomaram medidas para aumentar a participação do elemento humano: expandiram a lei (halakhah), criaram mais sinagogas e disseminaram o estudo dos textos sagrados. A palavra de Deus ${ }^{666}$, que deixou de ser transmitida de maneira clara por profetas, passou a ser difundida através dos rabinos, que se baseiam fortemente em sua própria capacidade interpretativa.

Quando opiniões rabínicas individuais diferissem, a decisão seria tomada pela maioria, sem esperar uma revelação divina - ou mesmo desprezando-a, caso acontecesse ${ }^{667}$. Com isso, o papel dos judeus na Aliança tornou-se mais ativo. Para

\footnotetext{
${ }^{664}$ Greenberg, 1993, pg. 83.

${ }^{665}$ Greenberg cita como exemplo esta passagem do Tratado Shabat 119b, do Talmud da Babilônia:
}

"Rabi Hamuna disse: 'Aquele que recita na noite do shabat a prece Vaichlu (ויכלו) *, o texto o eleva a tal ponto que é como se se tornasse um parceiro (שותף) do Abençoado-Seja-Ele (Deus) na Criação do Mundo."

* a prece Vaichlu (ויכלו), que compreende Gn 2:1 a 3, é recitada na noite de sexta-feira (início do shabat).

(Greenberg, 1981,pg. 8)

${ }^{666}$ Greenberg, 1993, pgs. 83 e 85.

${ }^{667}$ Greenberg (1981, pg. 10) ilustra esta situação através da célebre história da excomunhão de Rabi Eliezer ben Hyrkenos, encontrada no Tratado Baba Mezia 59a/b, do Talmud da Babilônia:

"(Sobre a questão se um forno constituído por diversas partes seria ritualmente puro) Rabi Eliezer o declarou puro e os sábios o declararam impuro (...) Naquele dia, Rabi Eliezer apresentou todo argumento imaginável, mas não aceitaram. Disse ele (Eliezer): 'se a halakhah concorda comigo, que esta árvore prove isto!'. Por causa disso, a árvore foi despedaçada a cem cúbitos de seu lugar (...) 'Nenhuma prova pode ser dada a partir de uma árvore', retorquiram [os sábios]. De novo, ele (Eliezer) disse: 'se a halakhah concorda comigo, que esta correnteza de água prove isto!'. Em seguida, a correnteza mudou de direção. 'Nenhuma prova pode ser dada a partir de uma correnteza de água', responderam. Novamente ele insistiu: 'se a halakhah concorda comigo, que as paredes da Casa de Estudos prove isto!'. Consequentemente, as paredes se inclinaram, quase caindo. Mas Rabi Yehoshua repreendeu [as paredes] dizendo: 'por que vocês intereferem quando estudiosos estão ocupados numa questão sobre halakhah?'. Por isso não caíram, em honra a Rabi Yehoshua, mas também não voltaram à sua posição original, em honra a Rabi Eliezer. E até hoje estão inclinadas. Novamente ele (Eliezer) 
Greenberg, os rabinos entenderam claramente que eram, ao mesmo tempo, conservadores da tradição e construtores de algo novo (eles herdaram a Aliança da Bíblia Hebraica, mas modificaram o status do indivíduo no relacionamento com Deus) ${ }^{668}$.

Já com o advento do Holocausto, a Aliança foi atacada de maneira excepcional ${ }^{669}$. A sobrevivência dos judeus que, como vimos, estaria garantida por Deus através da Aliança, foi negada. A Aliança afirma que a vida humana tem valor infinito, porém a Shoá contradisse isto ${ }^{670}$. Nesta situação, a ligação entre Deus e o

disse: 'se a halakhah concorda comigo, que seja provado pelo Céu!'. Então uma voz celestial (בת קול) afirmou: 'Por que vocês disputam com Rabi Eliezer, visto que em todas as questões a halakhah concorda com ele?'. Mas Rabi Yehoshua levantou-se e disse: 'Não está no Céu'. O que ele quis dizer com isto? Explicou Rabi Yrmiah: 'a Torá já foi dada no Monte Sinai; não prestamos atenção à voz celestial; pois Tu há muito tempo escreveu na Torá no Monte Sinai: pela maioria deve-se decidir'.”

Esta célebre agadah continua do seguinte modo:

"Rabi Nathan encontrou [o profeta] Eliahu e perguntou a ele: 'o que o Santo-Abençoado-Seja-Ele (Deus) faz nesse momento (quando os rabinos rejeitam a voz celestial)?'. [O profeta] responde: 'Ele ri (de alegria) e exclama: meus filhos me derrotaram, meus filhos me derrotaram!'. Naquele dia, todos os objetos declarados puros por Rabi Eliezer foram reunidos e queimados. Em seguida, excomungaramno".

${ }^{668}$ Este papel (Greenberg, 1993, pg. 86) de conservadores-inovadores está representado numa agadah do Tratado Menahot 29b, do Talmud da Babilônia. Nela, Moisés é transportado por Deus a uma aula de Rabi Akiva, 1.400 anos à frente de sua morte. Moisés não compreende as lições do rabino - mostrando a inovação trazida pelo rabinismo -, mas quando Akiva é interrogado por seus alunos sobre determinada questão, ele remete seu conhecimento a Moisés - transmitindo assim a idéia de conservação da tradição. Eis o texto da agadah:

"Quando Moisés ascendeu ao céu, encontrou o Santo-Abençoado-Seja-Ele (Deus) ocupado em adicionar coroas (detalhes) às letras [da Bíblia]. Disse Moisés: 'Senhor do Universo, quem detém Sua mão?' (significando: Há algo faltando na Torá que torna estas adições necessárias?). Ele respondeu: 'Levantar-se-á um homem, no final de muitas gerações, Akiva ben Yosef (Rabi Akiva)é seu nome, que esclarecerá cada detalhe das halakhot (leis judaicas)'. Disse Moisés: 'Senhor do Universo, permita-me vê-lo'. Ele repondeu: 'Vire-se'. Moisés foi e sentou-se atrás da oitava fileira (de estudantes na yeshiva de Rabi Akiva, enquanto este falava sobre a halakhah). Não podendo acompanhar as argumentações, [Moisés] sentiu-se desconfortável. Mas quando chegaram a um certo assunto e os discípulos perguntaram ao mestre 'De onde sabes isto?', ele (Akiva) respondeu: 'É uma lei dada a Moisés no Sinai'. E ele (Moisés) sentiu-se confortado."

Esta famosa agadah continua da seguinte maneira:

"Por causa disto, ele (Moisés) retornou ao Santo-Abençoado-Seja-Ele (Deus) e disse: 'Senhor do Universo, Tu tens tal homem [à disposição] e deste a Torá através de mim!'. Ele respondeu: 'Silêncio, pois este é Meu decreto!'. Então disse Moisés: 'Senhor do Universo, mostraste-me sua (de Akiva) Torá, mostre-me [agora] sua recompensa'. 'Vire-se', Ele disse. Moisés virou-se e viu-os pesando a carne dele (de Akiva, após ser morto pelos romanos) no açougue. Gritou Moisés: 'Senhor do Universo, esta é a Torá e esta é a recompensa!'. Ele respondeu: 'Silêncio, pois este é Meu decreto!'."

${ }_{669}^{60}$ Greenberg, 1993, pgs. 90 e 91.

${ }^{670}$ Para frisar este ponto, Greenberg reproduziu dois testemunhos do Holocausto, que contam crueldades extremas cometidas contra crianças. No primeiro deles (Greenberg, 1977, pgs. 9 e 10), um guarda polonês de Auschwitz, interrogado durante o Julgamento de Nuremberg, narra atrocidades ocorridas durante o verão de 1944:

TESTEMUNHA: As crianças eram separadas de seus pais fora do crematório e enviadas sozinhas às câmaras-de-gás. Quando o extermínio dos judeus estava no ápice, foram emitidas ordens para as crianças serem lançadas diretamente as fornos ou a covas perto do crematório, sem serem mortas por gás antes. 
povo judeu ficou comprometida. "Como não pode haver uma Aliança sem um povo para pactuar, a Aliança não se quebra neste evento?”, questiona Greenberg ${ }^{671}$.

A crise da Aliança trazida pelo Holocausto é profunda e torna-se necessário perguntar se o Pacto realmente não terminou, aponta Greenberg ${ }^{672}$. Através da Shoá, ficou claro que, ao concordar com o chamado de Deus para serem testemunhas, os judeus se expuseram a uma fúria assassina da qual não havia escapatória. "A divindade não pôde ou não quis salvar os judeus deste destino. Portanto, do ponto-devista moral, Deus precisa ter remorso pela Aliança, isto é, arrepender-se de ter dado a Seu povo uma tarefa insuportavelmente cruel e perigosa, sem ter provido proteção" ${ }^{\text {673 }}$. Após o Holocausto, toda afirmação sobre a preocupação divina com a humanidade precisa ser feita com "grande moderação" 674.

A mudança fundamental na Era Pós-Holocausto é que a Aliança não pode mais ser imposta, afirma Greenberg. "Não se pode ordenar que alguém caminhe para a morte" ${ }^{675}$. Para o rabino, é possível pedir a alguém que se sacrifique, mas isto não pode ser comandado; não se pode ordenar a alguém que siga numa missão suicida. Pode-se apenas pedir isto a voluntários ${ }^{676}$.

Os judeus ${ }^{677}$, após o Holocausto, sabem que, devido à sua religião, expõem a si mesmos, seus filhos e netos a um perigo extremo. Por isso, nenhuma punição divina

SMIRNOV (promotor público russo): Como devo entender isto ? Eles a jogavam vivas no fogo ou as matavam antes?

TESTEMUNHA: Eles a arremessavam vivas. Seus gritos podiam ser ouvidos através do campo. É difícil dizer quantas crianças foram destruídas desta maneira.

SMIRNOV: Por que faziam isto?

TESTEMUNHA: É muito difícil dizer. Não sabemos se queriam economizar gás ou porque não havia lugar suficiente nas câmaras-de-gás.

Em outra passagem, Greenberg (Greenberg, 1993, pg. 91) reproduz o testemunho de um prisioneiro:

"Quando um dos SS tinha algum tipo de compaixão pelas crianças, pegava uma delas e batia sua cabeça contra uma pedra, para que perdesse a consciência antes de colocá-la na pilha de madeira e fogo. No entanto, a forma rotineira era apenas jogar as crianças na pilha. Eles colocavam madeira, encharcavam com gasolina, depois mais madeira e gasolina, madeira e gasolina - e aí punham as crianças ali. Depois, tudo aquilo era aceso".

${ }^{671}$ Greenberg, 1993, pgs. 91e 92.

${ }^{672}$ Greenberg, 1993, pg. 92.

${ }^{673}$ Greenberg, 1993, pg. 92.

${ }^{674}$ Greenberg, "Religious Values...", pg. 76.

${ }^{675}$ Greenberg, 1993, pg. 92.

${ }^{676}$ Greenberg, 1993, pg. 92.

${ }^{677}$ Greenberg, 1993, pgs. 92 e 93. 
pode impôr a Aliança, pois não há nenhum castigo tão terrível que possa ser comparado aos riscos de se continuar fiel à ela.

Devido à Shoá ${ }^{678}$, os judeus têm todo o direito de questionar ou mesmo rejeitar a Aliança. Se após a destruição do Primeiro Templo discutiu-se através dos profetas se Deus rechaçara o Pacto, agora, após a destruição do judaísmo europeu pelo nazismo, a discussão é se os judeus rejeitarão a Aliança.

Por outro lado, frisa Greenberg, a grande maioria dos sobreviventes decidiu reconstruir suas vidas após a Shoá seguindo o judaísmo. Novas yeshivot foram criadas e crianças foram educadas segundo os preceitos judaicos. Também a criação do Estado de Israel envolveu participação significativa do povo judeu ${ }^{679}$.

Como fica, portanto, a Aliança após o Holocausto ? Agora, afirma Greenberg, a Aliança é voluntária. "Eu sugiro a idéia de que a autoridade da Aliança foi quebrada, mas o povo judeu, livre de suas obrigações, decidiu voluntariamente contratá-la novamente. Estamos vivendo uma época de renovação da Aliança. Deus não está mais numa posição de impô-la, mas o povo judeu enamorou-se de tal maneira com o sonho da redenção, que se voluntariou para continuar sua missão" ${ }^{680}$.

Se, após a destruição do Segundo Templo ${ }^{681}$, os judeus passaram a ter maior parcela de responsabilidade na Aliança e tornaram-se parceiros graduados, agora, na Era Pós-Holocausto, a responsabilidade é total por parte dos judeus, que também se transformaram no principal parceiro do Pacto. "Deus está dizendo aos homens: Vocês é que devem parar a Shoá, vocês é que devem trazer a redenção" ${ }^{682}$.

As Escrituras foram o principal registro da Aliança "involuntária" na Era Bíblica. Já o Talmud foi o grande registro da Aliança na Era Rabínica. Qual será o registro na era atual, quando a Aliança entrou em sua fase "voluntária" ${ }^{683}$ ?

\footnotetext{
${ }^{678}$ Greenberg, 1993, pg. 93.

${ }^{679}$ Greenberg, 1993, pg. 93.

${ }^{680}$ Greenberg, 1993, pgs. 93 e 94.

${ }^{681}$ Greenberg, 1993, pgs. 94 e 95.

${ }^{682}$ Greenberg, 1993, pg. 95.

${ }^{683}$ Greenberg, 1979, pg. 81.
} 
Greenberg fornece duas respostas bem diferentes para esta questão, em ensaios distintos.

A primeira ${ }^{684}$ é reconhecer nas memórias dos sobreviventes do Holocausto e dos construtores do Estado de Israel o registro desta nova fase. Para o pensador, estes testemunhos não são menos grandiosos e significativos que as histórias bíblicas de Jacó ou Rute. Apenas ainda é cedo demais para se saber quais destes relatos contemporâneos entrarão para o cânone definitivo da Era Pós-Holocausto.

A outra resposta de Greenberg ${ }^{685}$ é afirmar que, desta vez, o registro não será feito em obras escritas, mas através de ações nobres visando a preservação da vida. Desta maneira, os judeus darão um exemplo à humanidade de uma comunidade que foi vítima de genocídio e degradação, mas que se renova. "Novamente eles (os judeus) mostram modelos de vida, de reconciliação entre o indivíduo e comunidade (...) De novo, eles mostram que a morte pode ser superada por hesed ${ }^{686}$, amor e esperança. Poderia haver uma testemunha mais poderosa da imagem divina e do fundamento divino da vida?" 687.

\section{5 - Livre Arbítrio}

A fase "voluntária" da Aliança, inaugurada de forma dramática pelo Holocausto, já estava implícita no modelo pactual de Deus com Israel desde seus primórdios, afirma Greenberg ${ }^{688}$. Isto porque uma Aliança imposta (“involuntária”) contradiz, por princípio, o livre-arbítrio humano. E como Deus respeita a liberdade de

\footnotetext{
${ }^{684}$ Greenberg, 1981, pgs. 39 a 42.

${ }^{685}$ Greenberg, 1979, pg. 81.

${ }^{686}$ Hesed (חס) - "benevolência, graça, bom tratamento".

${ }^{687}$ Greenberg projeta para a nova fase "voluntária" da Aliança o mesmo papel de povo-modelo que os judeus tiveram nas fases anteriores da Aliança. Para o pensador, os dilemas enfrentados pelos judeus na Era Pós-Holocausto - como reconstruir uma comunidade sem perder a memória do passado ou como conciliar nacionalismo com as necessidades de outros povos - servirá de modelo para a humanidade, quando devidamente solucionados. "[O modelo] será estudado e imitado por toda parte e novamente a antiga benção da Aliança será cumprida: 'Em ti serão abençoadas todas as famílias da Terra (Gn $12: 3)^{\prime \prime \prime, ~ e s c r e v e . ~}$

(Greenberg, 1981, pgs. 41 e 42)

${ }^{688}$ Greenberg, 1993, pgs. 78 e 96.
} 
escolha, a adesão dos judeus à Aliança de forma "voluntária" teria que acontecer em alguma fase da História.

Deus deseja a inauguração da era messiânica, mas não força os homens a aceitá-la. Os seres humanos têm a liberdade de decidir se desejam ou não a redenção e a participação no processo messiânico. Deus garantiu, através da Aliança com Noé ${ }^{689}$, que não destruiria o mundo, não importando o grau de decadência a que chegasse. Mas mesmo tendo esta garantia divina, a humanidade também pode optar por um caminho onde o mal predomine, como aconteceu no Holocausto ${ }^{690}$.

A humanidade ${ }^{691}$ pode exercer seu livre-arbítrio optando por um caminho que não leve à perfeição final. Existe o perigo real de se chegar, no final de todo o processo histórico, a uma situação bem inferior ao ideal messiânico. "Deus se encontra entre a liberdade concedida ao ser humano e a dignidade final que deseja que seja a de toda a humanidade. Mas forçar a liberdade final não é a maneira das pessoas se tornarem livres", escreve o rabino.

\section{6 - Ocultamento da Face}

A Era Bíblica foi marcada por um elevado grau de intervenção de Deus nos assuntos humanos. A divindade abriu o Mar Vermelho para os israelitas fugirem do Egito, participou da conquista da Terra Prometida ao lado de Josué, fez-se presente no Templo de Jerusalém e manifestou-se através dos profetas ${ }^{692}$.

\footnotetext{
${ }^{689}$ Segundo Greenberg, após a Aliança com Noé, houve a necessidade de uma outra Aliança, desta vez com o povo judeu. Nesta última, que não eliminou a anterior, os judeus prometeram a Deus que se tornariam um modelo para a humanidade, ensinando o caminho rumo à perfeição e à redenção. Como consequência, ciente de que os judeus estão comprometidos com esta missão, Deus aceitou liberar todo o restante da humanidade para que exercesse o livre-arbítrio.

(Greenberg, 1993, pg. 79)

${ }^{690}$ Greenberg, 1993, pg. 78; Greenberg, “Judaism and Christianity...”, pg. 142.

${ }^{691}$ Greenberg, 1993, pg. 79.

${ }^{692}$ Greenberg, 1981, pgs. 5 e 6.
} 
Já na Era Rabínica, Deus "ocultou Sua face" de maneira pronunciada, afastando-se dos assuntos mundanos ${ }^{693}$. Ao contrário do que acontecia no Templo de Jerusalém, nas sinagogas rabínicas a divindade não se pronuncia mais ${ }^{694}$.

Já na Era Pós-Holocausto ${ }^{695}$, sob a perspectiva dos campos-de-concentração e do total abandono das vítimas frente ao algoz nazista, Greenberg conclui que Deus optou por se afastar de maneira ainda mais profunda dos assuntos mundanos. O "ocultamento da face" na atualidade é ainda maior do que aquele demonstrado por Deus na Era Rabínica. Durante e após a Shoá, a divindade adotou um "radical autocontrole".

Uma decorrência fundamental do maior afastamento de Deus dos assuntos mundanos é que a humanidade passa a viver num ambiente de maior secularização. Tudo se passa como se não existisse um Deus que interferisse nos assuntos humanos. “Quando um pobre pede ajuda, não se deve responder: Deus te ajudará. Seja um ateu e torne-se completamente responsável pelo necessitado", escreve o rabino ${ }^{696}$.

Vários fatores apontam para a maior secularização do judaísmo na Era PósHolocausto. O Estado de Israel, fundado por um movimento político secular (sionismo), passou a ocupar um lugar central na vida judaica ${ }^{697}$. Por absorver parte significativa da "energia espiritual" do povo judeu na atualidade, esta instituição política terá como efeito aprofundar ainda mais a secularização do judaísmo. Também

\footnotetext{
${ }^{693}$ Os rabinos do Talmud (Greenberg, 1981, pg. 10) reconheceram este distanciamento e o ilustraram com o Livro de Ester. Neste texto tardio da Bíblia Hebraica, o nome de Deus não aparece em nenhum momento e os judeus são salvos da destruição exclusivamente através de manobras políticas. Os rabinos viram neste Livro um paradigma de uma nova época em que Deus "ocultaria Sua face" e não salvaria mais através de intervenção direta, mas mesmo assim redimiria o povo de Israel. Eles expressaram isto na célebre passagem do Tratado Shabat 88a, do Talmud da Babilônia, onde a Torá aparece como imposta no Sinai aos judeus e estes só a aceitam de espontânea vontade muito posteriormente, na época de Ester (reconhecendo a presença de Deus mesmo numa situação de "ocultamento da face"):

"E eles (israelitas) ficaram parados bem no sopé da montanha (Sinai)" [Ex19:17]. Rabi Abdimi bar Hama bar Hasa disse (interpretou este versículo como sendo): Isto ensina que [Deus] virou a montanha sobre eles como um barril e disse 'Se vocês aceitarem a Torá, muito bem; caso contrário este será seus sepultamentos'. Rabi Aha bar Jacó observou: [Mas] isto fornece um forte protesto contra a Torá (dá uma desculpa para não cumpri-la, pois foi imposta). Disse Raba: Mas mesmo assim, eles (judeus) a reaceitaram (a Torá) nos dias de Ahasverosh (Esther), pois está escrito: '[os judeus] aceitaram e tomaram sobre si' (Ester 9:27), [ou seja,] eles confirmaram o que haviam aceito muito antes".

${ }^{694}$ Greenberg, 1981, pg. 8.

${ }^{695}$ Greenberg, "Religious Values...”, pg. 82; Greenberg, 1978, pg. 159.

${ }^{696}$ Greenberg, 1978, pg. 160.

${ }^{697}$ Greenberg, 1978, pgs. 158 e 159
} 
contribuirá para isto o fato de políticos - "e quem poderia transmitir uma imagem mais secular que eles?" ${ }^{698}$ - do Estado de Israel passarem a decidir sobre assuntos prioritários da vida judaica.

Num ambiente mais secular, até o papel da sinagoga poderá sofrer uma transformação radical ${ }^{699}$. A própria existência da sinagoga não está assegurada. Da mesma maneira que a destruição do Segundo Templo fez desaparecer para sempre a classe sacerdotal judaica, talvez o hurban do século XX condenará os rabinos ao desaparecimento. Eles poderão ter como sucessores mestres que possam dar a mesma orientação judaica, mas através de atividades seculares. "Não é provável que a sinagoga seja o veículo da perpetuação judaica”, afirma o pensador ${ }^{700}$.

Da mesma maneira que as sinagogas se multiplicaram no início da Era Rabínica, na Era Pós-Holocausto é a vez dos Museus da Shoá se multiplicarem no mundo todo ${ }^{701}$. Provavelmente não ocuparão um lugar tão central na vida judaica como as sinagogas, porém já se transformaram na atualidade num novo "espaço sagrado" para o estudo e a reflexão sobre o hurban do século XX.

Como parte deste maior secularismo, os judeus resolveram criar por conta própria novos dias santos tanto para recordar o hurban da Europa quanto para celebrar a criação do Estado de Israel (respectivamente, o Dia da Shoá e o Dia da Independência). Apesar dessas datas serem basicamente seculares, já se tornaram parte do calendário judaico anual, aponta o rabino ${ }^{702}$.

Também novos rituais seculares ${ }^{703}$ surgiram na vida judaica como consequência do Holocausto, notadamente a peregrinação a campos-de-concentração da Europa e viagens a Israel. Novas orientações éticas surgidas após a Shoá ("lembrese da fome em Auschwitz, portanto alimente o faminto") reforçam a presença de um forte elemento desacralizado.

\footnotetext{
${ }^{698}$ Greenberg, 1981, pg. 35.

${ }^{699}$ Greenberg, 1978, pg. 159.

${ }^{700}$ Greenberg, 1978, pg. 160.

${ }^{701}$ Greenberg, 1998, pgs. 229 e 231.

${ }^{702}$ Greenberg, "Religious Values...", pg. 84.

${ }^{703}$ Greenberg, "Religious Values...", pg. 84.
} 
Nesta época de maior secularismo, não se trata de esquecer a promessa messiânica, aponta Greenberg. A postura do homem religioso é de aumentar sua atividade no mundo, orientada para trazer a redenção final ${ }^{704}$. A atividade humana torna-se veículo de intervenção divina, uma situação que o rabino norte-americano chama de "secularismo sagrado" 705.

Este maior secularismo ${ }^{706}$ também não deve ser tomado como uma mostra de "morte de Deus". Embora "oculto", a divindade está presente no mundo, afirma Greenberg, como também esteve nos campos-de-concentração e guetos nazistas, "passando fome, sendo espancado, humilhado, gaseado e queimado vivo". Da mesma maneira, a divindade participou de eventos redentores da Era Pós-Holocausto, como a criação do Estado de Israel ${ }^{707}$.

\section{7 - Caráter Religioso do Estado de Israel}

Na Era Pós-Holocausto, os judeus resolveram, por conta própria, restabelecer um Estado independente. Para Greenberg, isto foi uma consequência de Deus ter aprofundado Sua ausência no mundo e, assim, conclamado os judeus a agirem mais ativamente. "Deus disse aos homens: Vocês parem a Shoá, vocês tragam a redenção (...) O povo judeu ouviu este chamado e respondeu (...) criando o Estado de Israel" ${ }^{\text {"708. }}$.

Para Greenberg, o Estado de Israel está carregado de significado religioso. Esta entidade política foi uma resposta ao nazismo ${ }^{709}$, que atacou o judaísmo, a Aliança e a própria presença de Deus no mundo, ao tentar eliminar o povotestemunha. A fundação do Estado de Israel ${ }^{710}$ foi uma reafirmação de que o Deus de

\footnotetext{
${ }^{704}$ Greenberg, 1978, pg. 160.

705 Greenberg, "Religious Values...", pg.77.

${ }^{706}$ Greenberg, 1981, pgs. 17 e 18.

${ }^{707}$ Greenberg baseia-se no Talmud da Babilônia, Tratado Meguila 29a:

"Para cada lugar que eles (Israel) foram exilados, a Shekhinah os acompanhou. Eles foram exilados no Egito e a Shekhinah estava com eles (...) Eles foram exilados na Babilônia e a Shekhinah estava com eles (...) E quando eles forem redimidos no futuro, a Shekhinah [também] estará com eles.”

${ }^{708}$ Greenberg, 1993, pg. 95.

${ }^{709}$ Greenberg, 1993, pg. 97.

${ }^{710}$ Greenberg, 1993, pg. 98.
} 
Israel existe, apesar de "oculto". "A resposta central judaica foi recriar o principal símbolo bíblico e garantidor da validade da Aliança, ou seja, a presença soberana judaica na Terra de Israel" 711 .

Isto não quer dizer que, para Greenberg, o Estado de Israel seja uma recompensa ou contrapartida pelo Holocausto. A maldade do nazismo não poderia ser apagada por um outro evento histórico. "O Estado de Israel não é uma recompensa ou um produto ou uma troca pelo Holocausto, mas sim uma resposta. O povo judeu respondeu ao total assalto da morte por uma incrível emanação de vida" ${ }^{712}$. Como consequência, afirma o rabino, Shoá e Estado de Israel, representando destruição e redenção, conviverão em contraste, numa "irremediável tensão dialética" ${ }^{713}$.

Greenberg ${ }^{714}$ compara a criação do Estado de Israel ao Êxodo do Egito, o evento histórico fundamental do judaísmo. Se no Êxodo 600 mil israelitas deixaram a escravidão para receber os mandamentos no Sinai como homens livres, no século XX 500 mil sobreviventes da perseguição nazista foram absorvidos no novo Estado judeu. Greenberg vê na fundação desta entidade política moderna o cumprimento da profecia de Jeremias: "Dias virão em que não mais se dirá: 'Certo como vive o Senhor, que fez os israelitas subirem da terra do Egito', e sim: 'Certo como vive o Senhor, que fez os israelitas subirem (...) de todas as terras onde os tinha dispersado"” (Jr 16:14 e 15).

Por isso, uma decisão individual de apoiar o Estado de Israel é interpretada por Greenberg como a aceitação do mandamento de ser testemunha da existência de Deus. "É a aceitação da mitzvah de (...) construir uma realidade social de redenção e até mesmo de trazer o Messias" 715.

Greenberg considera ${ }^{716}$ que até o judeu "mais amargamente secular e ateu", mas que age de alguma maneira para a construção do Estado de Israel, está na linha de frente do processo messiânico. Isto mesmo levando-se em conta que o país não

\footnotetext{
${ }^{711}$ Greenberg, “Religious Values...”, pg. 83.

${ }^{712}$ Greenberg, 1988, pg. 339.

${ }^{713}$ Greenberg, 1988, pg. 339.

${ }^{714}$ Greenberg, 1979, pg. 69.

${ }^{715}$ Greenberg, 1993, pg. 98 .

${ }^{716}$ Greenberg, 1977, pgs 43, 49 e 60.
} 
aceita a halakhah como sua base legislativa e que muitos de seus cidadãos judeus "neguem vigorosamente a Aliança" 717 .

Se muitos israelenses não se sentem comprometidos com a tarefa de criar uma sociedade-modelo messiânica, isto é devido à nova fase da Aliança vivida pelo povo judeu na Era Pós-Holocausto. Numa situação de adesão "voluntária" ao Pacto, não pode haver um objetivo imposto de Cima. A única ação possível para o homem religioso é tentar persuadir seu companheiro, alheio à idéia messiânica, a fazer parte deste processo ${ }^{718}$.

Quanto ao papel de Deus na criação do Estado de Israel, Greenberg aponta ${ }^{719}$ que um hurban da magnitude do Holocausto desafiou de tal maneira as afirmações da Aliança, que fez-se necessária uma imediata realização redentora por parte da divindade, para contrabalancear a destruição. Proporcionalmente à destruição da Shoá, fez-se necessário um contra-evento de proporções messiânicas. Uma catástrofe sem precedentes teria mesmo que ser seguida por um ato de redenção sem precedentes, para que os judeus continuassem fiéis ao Deus que comanda a História.

Isto aconteceu através do estabelecimento do Estado de Israel, com a "incrível natureza" ${ }^{720}$ do novo país. Este foi "o mais poderoso sinal messiânico de nossa era",721. Sendo uma entidade política que reafirma a sobrevivência dos judeus após uma grande tentativa de aniquilação, o país fornece testemunho da contínua presença de Deus na História ${ }^{722}$.

O Estado de Israel ${ }^{723}$ não é apenas mais uma nação entre as demais, mas uma sociedade que deve simbolizar liberação e redenção para toda a humanidade. Greenberg aplica ao Estado de Israel o ideal do profeta Isaías de "luz das nações" (Is

\footnotetext{
${ }^{717}$ Para Greenberg, o fato da maioria da população israelense apoiar a existência de uma lei que garante cidadania automática a todo judeu do mundo que queira imigrar ao país (Lei do Retorno) significa que "eles (israelenses seculares) se recusam a (...) cortar a ligação entre o povo histórico da Aliança e o corpo político do atual Israel” (Greenberg, 1977, pg. 49).

${ }_{718}$ Greenberg, 1993, pg. 95.

${ }^{719}$ Greenberg, 1993, pgs. 102 e 103; Greenberg, 1977, pg. 32.

${ }^{720}$ Greenberg, 1993, pg. 103.

${ }^{721}$ Greenberg, 1998, pg. 324.

722 Greenberg, 1977, pg. 48.

${ }^{723}$ Greenberg, 1993, pg. 95.
} 
49:6). Daí ele interpretar feitos da história israelense como tendo significado transcendental. Por exemplo, ao desenvolver técnicas avançadas de agricultura no deserto, Israel oferece ao mundo um caminho para vencer a pobreza e a fome. É uma ação exemplar, "particularmente importante para o Terceiro Mundo, onde a massa da humanidade luta com os problemas da pobreza, fatalismo e renovação de instituições sociais".

O Estado de Israel também representa um exemplo às demais nações de um povo que sai de uma situação de vítima de genocídio e decide mudar sua situação política. Para Greenberg, foi seguindo o exemplo político dos judeus que surgiram movimentos revolucionários e de libertação nacional no Terceiro Mundo durante o século XX. Também as campanhas por direitos civis e de liberação feminina dos anos 60 foram inspirados no exemplo dado pelos judeus ${ }^{724}$.

Se o Estado de Israel é uma instituição exemplar, como Greenberg avalia o desempenho político do país desde sua fundação? O pensador tratou deste assunto no ensaio The Ethics of Jewish Power, publicado em 1990, onde analisou acontecimentos contemporâneos tais como a Guerra do Líbano, os excessos cometidos pelo serviço de segurança israelense e a Primeira Intifada (levante palestino do final da década de 80 e início da década de 90).

Greenberg afirma neste ensaio ${ }^{725}$ que o Estado de Israel retomou uma situação que não se via há 2 mil anos, onde judeus detêm soberania sobre um território e exercem poder político. A clássica concepção do judeu como eterno inocente e moralmente superior devido à sua falta de poder foi abalada por imagens de "soldados judeus batendo em árabes e quebrando braços e pernas de civis, não só de terroristas" 726

Realmente, admite Greenberg, o poder corrompe. Porém, não há outra opção moralmente tolerável para os judeus a não ser obter poder ${ }^{727}$. A alternativa seria a

\footnotetext{
${ }^{724}$ Greenberg, 1998, pgs. 250 e 251; Greenberg, 1981, pg. 41.

${ }^{725}$ Greenberg, 1990, pg. 22.

${ }^{726}$ Greenberg, 1990, pg. 22.

${ }^{727}$ Greenberg, 1990, pgs. 22 e 23.
} 
morte. Se o poder corrompe, a falta dele corrompe ainda mais. "Esta é a lição que o povo judeu aprendeu do Holocausto", afirma o rabino.

Qualquer exercício de poder ${ }^{728}$, não importa quão bem intencionado, sempre terá efeitos colaterias imorais. Mas o fazer nada leva a um mal ainda maior que exercer poder. Por isso, aqueles que se recusam a usar o poder, por ser imoral, são culpados de se preocupar demais com sua auto-imagem, e isto é uma forma de egoísmo.

Num mundo ainda não redimido ${ }^{729}$, é necessário exercer poder para se proteger e também para fazer avançar o bem. Sem poder, não é possível fazer o bem. O uso do poder é, assim, julgado a partir do grau de perfeição do mundo atingido ao exercê-lo.

O verdadeiro moralista ${ }^{730}$ usa o poder, mas somente quando necessário, e tenta reduzir ao máximo o sofrimento causado por sua ação. Um exército moral usará somente a força necessária. Se usar menos força que a necessária, falhará e trairá aqueles que deveria proteger.

Se a quantidade de força necessária ${ }^{731}$ para atingir um objetivo de maneira moral não for clara, então o teste ético será a disposição de aceitar perdas do próprio lado para evitar que o inocente sofra. Em alguns casos, apenas o resultado final poderá servir de base para a avaliação da validade moral de uma ação.

A aplicação do poder militar judaico ${ }^{732}$ não está isenta de causar a morte de inocentes. Esta constatação pode ser penosa, mas pensar de maneira diferente seria assumir que os judeus são mais morais que os outros povos e isto indicaria um racismo disfarçado. Os judeus são como qualquer outro povo, afirma o rabino, baseando-se em Deuteronômio 9:6 : "Não é por seres (Israel) justo que o Senhor, teu Deus, te concede a posse desta boa terra, pois tu és um povo de dura cerviz".

\footnotetext{
${ }^{728}$ Greenberg, 1990, pg. 30.

${ }^{729}$ Greenberg, 1990, pg. 30; Greenberg, 1990, pg. 25.

${ }^{730}$ Greenberg, 1990,pgs. 30 e 31.

${ }^{731}$ Greenberg, 1990, pg. 30.

${ }^{732}$ Greenberg, 1990, pg. 32.
} 
A idéia ${ }^{733}$ de que os judeus são mais éticos que outros povos é uma ilusão, um produto da falta de poder durante séculos. O máximo que os judeus podem almejar é ser "cinco ou dez por cento" melhor que os outros - e isto já significaria o cumprimento da missão profética de serem "uma luz para as nações". Os judeus são um povo normal, que foram eleitos com o compromisso de criar uma comunidade moral, como parte da parceria entre homens e divindade visando aperfeiçoar o mundo.

Para Greenberg, é justamente neste momento, em que os judeus detêm poder político, que ficará claro se este povo possui algum nível mais elevado de moralidade, em comparação com outras nações. Ou se a inocência e pacificismo judaicos, demonstrados durante os séculos de exílio, foram simplesmente consequência da falta de poder ${ }^{734}$.

Greenberg até arrisca um "plano de paz” para o Oriente Médio ${ }^{735}$, afirmando que os palestinos deveriam formar um Estado independente na Cisjordânia e Gaza. Por outro lado, é moralmente correto o Estado judeu procurar manter uma vantagem militar sobre seus vizinhos árabes, enquanto estes não aceitarem sua existência. À medida que esta aceitação se expandir, aponta o rabino, deve ser buscado um equilíbio de forças na região.

Quanto aos colonos judeus que vivem nos territórios palestinos, Greenberg os classifica como produto de um "messianismo fora-de-controle" ${ }^{736}$. Para o rabino, é natural que após um grande hurban como o Holocausto surjam movimentos messiânicos equivocados, como o dos colonos. Isto também aconteceu após a destruição do Segundo Templo, com o líder rebelde Bar Kokhba sendo declarado messias; após a expulsão dos judeus da Espanha em 1492, que foi seguida por um forte misticismo cabalista de caráter messiânico; e após os pogroms promovidos pelo cossaco Bogdan Chmielnicki, na Ucrânia do século XVII, que deram origem ao movimento do falso-messias Shabetai Zvi.

\footnotetext{
${ }^{733}$ Greenberg, 1990, pgs. 32 e 33.

734 Greenberg, 1990, pg. 25.

735 Greenberg, 1990, pg. 34.

${ }^{736}$ Greenberg, 1998, pgs. 307 e 309.
} 
8 - 声

Greenberg aceita o modelo conceitual do Livro de Jó como aplicável para o caso do Holocausto - pelo menos em parte. Para o rabino, a utilização deste modelo é importante - uma "estratégia superior" 737 - para se poder entender o novo relacionamento com Deus na Era Pós-Holocausto.

Greenberg define o modelo de Jó como uma situação onde um justo exemplar sofre ao perder pessoas amadas, saúde e propriedades; o inocente não rejeita Deus, mas também não aceita que seu estado aflitivo seja explicado como um castigo divino por seus supostos pecados. Jó não se sente reconfortado pelos discursos de seus companheiros a respeito do poder e da majestade de Deus, e sua força interior somente é restabelecida quando sente novamente a presença divina. Isto permite que ele retome sua vida, mesmo destinado a conviver com perguntas irrespondidas sobre a condição humana ${ }^{738}$.

Para Greenberg ${ }^{739}$, aplicar o modelo de Jó ao Holocausto tem como consequência declarar a inocência das vítimas do nazismo; não aceitar justificações sobre os desígnios de Deus que pareçam inadaptáveis à situação da Shoá; insistir no fato de que sofrimento de pessoas inocentes levanta dúvidas e negações; estabelecer como condição para a renovação da fé em Deus a ocorrência de uma nova revelação divina.

Esta nova revelação após o Holocausto já ocorreu, afirma Greenberg, com a criação do Estado de Israel ${ }^{740}$. A independência política dos judeus foi um evento supra-natural, igualável à aparição de Deus no meio da tempestade no final da narrativa de Jó.

Porém, segundo Greenberg, o modelo teológico de Jó adapta-se apenas parcialmente no caso do Holocausto. Para os 6 milhões de judeus inocentes

\footnotetext{
${ }^{737}$ Greenberg, 1979, pg. 60.

${ }^{738}$ Greenberg, 1977, pgs. 34 e 35.

${ }^{739}$ Greenberg, 1979, pg. 60.

${ }^{740}$ Greenberg, 1979, pg. 60; Greenberg, 1977, pgs. 35.
} 
assassinados, não houve restauração, como houve para Jó. Não é possível aproximar a aparição redentora de Deus no final deste livro bíblico com o destino final das vítimas do nazismo. Tentar fazer uma identificação completa entre as duas situações "é inaceitável, por princípio" 741 .

\section{9 - Martírio}

Greenberg baseia-se ${ }^{742}$ em Menachem Ziemba, um dos últimos grandes rabinos de Varsóvia, assassinado no Holocausto, para elaborar sua concepção de Kidush Ha-Shem na Shoá. Em janeiro de 1943, Ziemba transmitiu publicamente sua opinião sobre qual deveria ser a postura dos judeus perante a ameaça iminente de destruição:

Temos que resistir em todas as frentes (...) Dadas as atuais condições, não há outra alternativa a não ser resistir. Estamos proibidos pela lei judaica de trair outras pessoas ou de nos entregarmos aos nossos arqui-inimigos (...) Kidush Ha-Shem se manifesta de formas variadas (...) Durante a Primeira Cruzada, no final do século XI, a halakhah (...) determinou uma maneira de reagir (...) Já em meados do século $X X$, durante a acelerada liquidação dos judeus da Polônia, a halakhah nos estimula a reagir de uma maneira totalmente diferente. No passado, durante perseguições religiosas, éramos obrigados pela lei a 'abdicar de nossas vidas em nome da menor de nossas práticas'. No presente, no entanto, quando enfrentamos um arqui-inimigo, cuja brutalidade não tem paralelos e cujos propósitos de aniquilação total não têm fronteiras, a halakhah exige que lutemos e resistamos até o fim, com determinação e valor inigualáveis, em nome do Kidush Ha-Shem.

Ecoando a posição do rabino Ziemba, Greenberg afirma que, na Era PósHolocausto, é necessária uma atitude judaica totalmente nova em relação ao martírio. A Shoá mostrou que um ataque maciço pode levar à aniquilação total do povo judeu, portanto uma tradição que estimule a entrega da vida não pode mais existir.

\footnotetext{
${ }^{741}$ Greenberg, 1977, pg. 34.

${ }^{742}$ Greenberg, 1979, pg. 61 / Zimmels, 1977, pgs. 60, 63 e 64.
} 
Voluntariar-se a morrer em nome do judaísmo tornou-se inadequado a partir da Segunda Guerra Mundial e não deve mais ser tolerado ${ }^{743}$.

Como exemplo desta nova postura, Greenberg defende a participação de judeus ortodoxos no exército do Estado de Israel e critica a liderança religiosa que se posiciona contra este alistamento. "No pós-Holocausto, [há a] necessidade do servo (povo judeu) pegar em armas para parar a agressão" 744 .

Para Greenberg, um outro aspecto da questão do martírio no Holocausto ${ }^{745}$, é que poderia parecer, à primeira vista, que os nazistas conseguiram eliminar toda a possibilidade dos judeus praticarem Kidush Ha-Shem, e, assim, dar um significado maior a suas mortes. O rabino, porém, vê a situação de forma diferente. Para ele, todo judeu assassinado durante o Holocausto, não importando sua ligação efetiva com o judaísmo, realizou Kidush Ha-Shem. Isto porque todo judeu, independentemente de sua filiação religiosa, testemunha a existência de Deus, a continuidade da Aliança e a esperança messiânica, mesmo que involuntariamente.

"Enquanto um só judeu estiver vivo, todo o (...) testemunho da tradição estará presente. Por isso, os nazistas quiseram destruir todos os judeus. Por isso (...) cada morte foi uma afirmação carregada de significado. A própria necessidade de matar judeus é, num certo sentido, uma afirmação de quão poderosa é a mensagem que eles ainda irradiam" 746 .

\section{8 - COMPARAÇÃO ENTRE OS PENSAMENTOS DE SOLOVEITCHIK, BERKOVITS E GREENBERG}

\footnotetext{
${ }^{743}$ Greenberg, 1979, pgs. 60 e 61; Greenberg, 1988, pgs. 386 e 387.

${ }^{744}$ Greenberg, 1979, pg. 61.

${ }^{745}$ Greenberg, 1988, pg. 338.

${ }^{746}$ Greenberg, 1988, pg. 338.
} 
8.1 - Quadro-Resumo

\begin{tabular}{|c|c|c|c|}
\hline & $\begin{array}{l}\text { Joseph } \\
\text { Soloveitchik }\end{array}$ & Eliezer Berkovits & Irving Greenberg \\
\hline Aliança & $\begin{array}{l}\text { O Holocausto não } \\
\text { abalou o status } \\
\text { do povo judeu } \\
\text { como povo eleito. }\end{array}$ & $\begin{array}{l}\text { O Holocausto não } \\
\text { abalou o status do } \\
\text { povo judeu como } \\
\text { povo eleitor A } \\
\text { perseguição contra } \\
\text { os judeus } \\
\text { representour o } \\
\text { desejo dos nazistas } \\
\text { de eliminar a fé em } \\
\text { Deus, através da } \\
\text { liquidação do povo- } \\
\text { testemunha. }\end{array}$ & $\begin{array}{l}\text { Deus não agiu para } \\
\text { garantir a sobrevivência } \\
\text { do povo judeu durante a } \\
\text { Shoá, conforme } \\
\text { estipulado nas cláusulas } \\
\text { da Aliança. Portanto, na } \\
\text { era pós-Holocausto, os } \\
\text { judeus têm o direito de } \\
\text { rejeitar o Pacto. A } \\
\text { adesão passa a ser } \\
\text { voluntária, e não mais } \\
\text { obrigatória. }\end{array}$ \\
\hline $\begin{array}{l}\text { Martírio } \\
\text { (Kidush Ha- } \\
\text { Shem) }\end{array}$ & $\begin{array}{l}\text { O rabino não } \\
\text { tratou do tema, } \\
\text { em relação ao } \\
\text { Holocausto. }\end{array}$ & $\begin{array}{l}\text { Houve } \\
\text { possibilidade de } \\
\text { morrer } \\
\text { “santtificando o } \\
\text { Nome” durante o } \\
\text { Holocausto, mas os } \\
\text { mártires } \\
\text { representaram uma } \\
\text { minoria entre as } \\
\text { vítimas. }\end{array}$ & $\begin{array}{l}\text { Todas as vítimas judias } \\
\text { do nazismo morreram } \\
\text { "santificando o Nome”. }\end{array}$ \\
\hline $\begin{array}{l}\text { Ocultamento } \\
\text { da Face }\end{array}$ & $\begin{array}{lr}\text { Ocultamento da } \\
\text { Face é uma forma } \\
\text { extremar de } \\
\text { punição divina } \\
\text { contra pecados } \\
\text { humanos. Deus } \\
\text { “ocultou rua } \\
\text { Face” do povo } \\
\text { judeu durante o } \\
\text { Holocausto, o que } \\
\text { resultou na } \\
\text { barbárier dos } \\
\text { campos-de- r } \\
\text { concentração. }\end{array}$ & 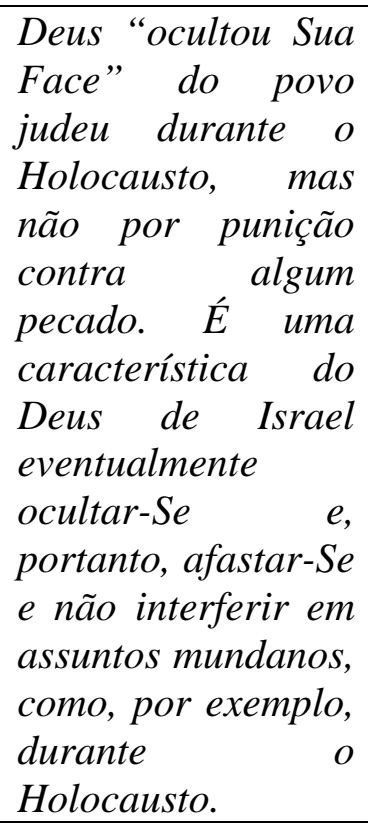 & $\begin{array}{l}\text { Deus “ocultou Sua face” } \\
\text { do povo judeu durante o } \\
\text { Holocausto. }\end{array}$ \\
\hline Livre Arbítrio & $\begin{array}{l}\text { O rabino não } \\
\text { tratou do tema, } \\
\text { em relação ao } \\
\text { Holocausto. }\end{array}$ & $\begin{array}{l}\text { O ser humano tem } \\
\text { ampla liberdade de } \\
\text { escolha assegurada } \\
\text { por Deus. O } \\
\text { Holocausto } \quad \text { foi } \\
\text { produto da má }\end{array}$ & $\begin{array}{lrr}\text { O Holocausto } & \text { foi } \\
\text { resultado do } & \text { livre- } \\
\text { arbítrio dos } & \text { seres } \\
\text { humanos. } & \text { Os } \\
\text { perpetradores } & \text { utilizaram } \\
\text { a liberdade de } & \text { escolha } \\
\end{array}$ \\
\hline
\end{tabular}




\begin{tabular}{|c|c|c|c|}
\hline & & 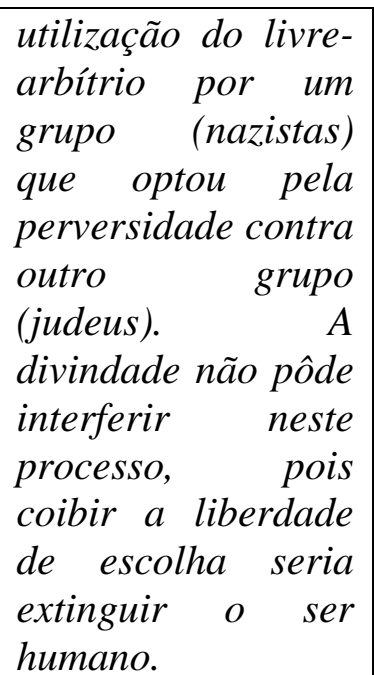 & $\begin{array}{l}\text { garantida à humanidade } \\
\text { por Deus, e optaram pela } \\
\text { maldade. }\end{array}$ \\
\hline $\begin{array}{l}\text { História como } \\
\text { Revelação } \\
\text { Divina }\end{array}$ & $\begin{array}{l}\text { Todo evento } \\
\text { histórico, } \\
\text { incluindo } \\
\text { Holocausto, ó } \\
\text { guiado por Deus } \\
\text { e tem uma } \\
\text { explicação lógica } \\
\text { dentro do plano } \\
\text { divino para o } \\
\text { universo. Porém, } \\
\text { nem sempre a } \\
\text { mente humana } \\
\text { consegue r no } \\
\text { penetrar divino e } \\
\text { desígnio divina } \\
\text { compreender a } \\
\text { lógica de de } \\
\text { determinado } \\
\text { evento. }\end{array}$ & 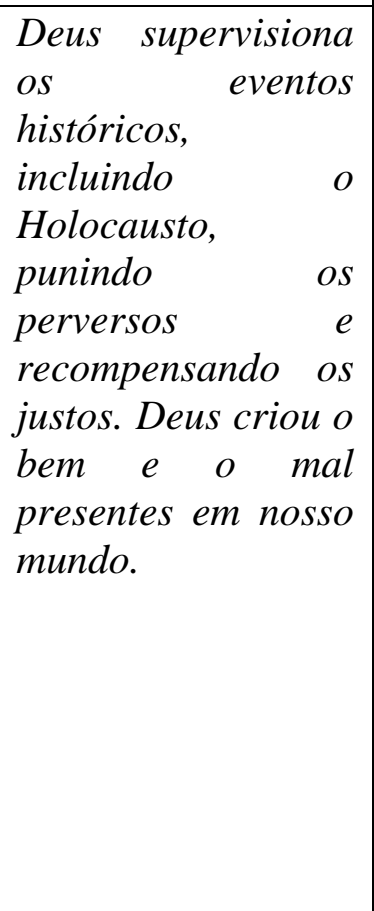 & $\begin{array}{l}\text { Os judeus atuam como } \\
\text { povo-testemunha perante } \\
\text { as demais nações, } \\
\text { afirmando que haverá } \\
\text { uma redenção futura } \\
\text { para toda a humanidade. } \\
\text { Porém, derrotas como o } \\
\text { Holocaustorrevantam } \\
\text { dúvidas sobrer a } \\
\text { credibilidade resta } \\
\text { missão e sobre a } \\
\text { possibilidade rade de } \\
\text { redenção. }\end{array}$ \\
\hline $\begin{array}{l}\text { Por Causa de } \\
\text { Nossos } \\
\text { Pecados }\end{array}$ & $\begin{array}{l}\text { Implicitamente, o } \\
\text { rabino indicou } \\
\text { que o Holocausto } \\
\text { foi punição divina } \\
\text { por algum pecado } \\
\text { do povo judeu. } \\
\text { Porém, náo } \\
\text { identificou qual } \\
\text { teria sido este } \\
\text { pecado. }\end{array}$ & 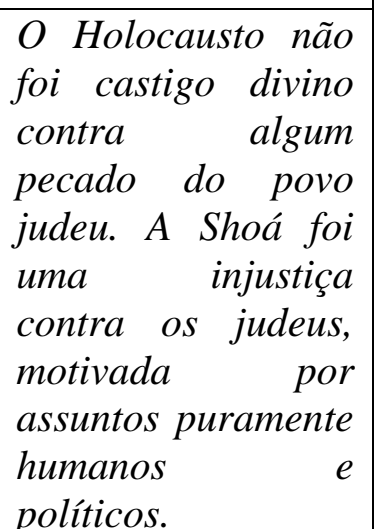 & $\begin{array}{l}\text { O Holocausto não foi } \\
\text { castigo divino contra } \\
\text { algum pecado do povo } \\
\text { judeu. }\end{array}$ \\
\hline Jó & $\begin{array}{l}\text { Jó foi um pecador } \\
\text { que teve que } \\
\text { passar por um } \\
\text { longo sofrimento } \\
\text { para superar seu } \\
\text { egoísmo. Jó }\end{array}$ & $\begin{array}{l}\text { Assim como Jó, os } \\
\text { judeus sofreram no } \\
\text { Holocausto sem ter } \\
\text { pecado. Portanto, } \\
\text { assim como o } \\
\text { personagem }\end{array}$ & $\begin{array}{l}\text { Assim como Jó, os judeus } \\
\text { sofreram no Holocausto } \\
\text { sem ter pecado. Também } \\
\text { como o personagem } \\
\text { bíblico, o povo judeu } \\
\text { deve rejeitar justificações }\end{array}$ \\
\hline
\end{tabular}




\begin{tabular}{|c|c|c|c|}
\hline & 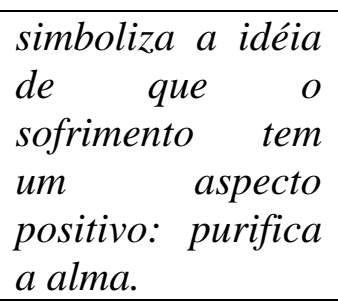 & $\begin{array}{lr}\text { bíblico, é legítimo } \\
\text { os sobreviventes } \\
\text { questionarem } & \text { onde } \\
\text { estava } & \text { Deus } \\
\text { durante } & \text { genocídio. }\end{array}$ & $\begin{array}{l}\text { teológicas inadaptáveis à } \\
\text { magnitude da Shoá e } \\
\text { insistir por uma nova } \\
\text { revelação divina. }\end{array}$ \\
\hline $\begin{array}{ll}\text { Significado } & \\
\text { Religioso do } \\
\text { Estado } & \text { de } \\
\text { Israel } & \end{array}$ & $\begin{array}{l}\text { A fundação do } \\
\text { Estado de Israel } \\
\text { foi um evento } \\
\text { guiado por Deus; } \\
\text { aparentemente, o } \\
\text { rabino não } \\
\text { considerou o país } \\
\text { como parte do } \\
\text { processo } \\
\text { messiânico. }\end{array}$ & $\begin{array}{l}\text { A fundação do } \\
\text { Estado de Israel foi } \\
\text { um evento guiado } \\
\text { por Deus e faz } \\
\text { parte do processo } \\
\text { messiânico. }\end{array}$ & $\begin{array}{l}\text { A fundação do Estado de } \\
\text { Israel tem caráter } \\
\text { religioso e messiânico. } \\
\text { Foi um evento } \\
\text { comandado por homens, } \\
\text { mas teve o efeito de } \\
\text { testemunhar a existência } \\
\text { de Deus. }\end{array}$ \\
\hline $\begin{array}{l}\text { Singularidade } \\
\text { do Holocausto }\end{array}$ & $\begin{array}{l}\text { O rabino não } \\
\text { opinou } \\
\text { diretamente sobre } \\
\text { este assunto. Mas } \\
\text { para um dos } \\
\text { comentaristas de } \\
\text { sua obra, ele não } \\
\text { teria considerado } \\
\text { o Holocausto } \\
\text { como um evento } \\
\text { único na História. }\end{array}$ & $\begin{array}{l}\text { O Holocausto não } \\
\text { foi um evento único } \\
\text { na história judaica } \\
\text { do ponto-de-vista } \\
\text { teológico. }\end{array}$ & $\begin{array}{l}\text { O Holocausto foi um } \\
\text { evento único na história } \\
\text { judaica. }\end{array}$ \\
\hline
\end{tabular}

\section{$\underline{8.2-\text { Análise }}$}

Baseado no Quadro-Resumo acima, podemos comparar as idéias dos três pensadores em relação a cada conceito e tema. Temos o seguinte:

Aliança - Soloveitchik e Berkovits concordam que o Holocausto não abalou o status do povo judeu como "eleito"; já Greenberg discorda e propõe uma reavaliação radical deste conceito como decorrência da Shoá.

Martírio - Berkovits e Greenberg discordam: o primeiro afirma que apenas uma minoria praticou Kidush Ha-Shem no Holocausto, já o segundo escreve que todos as vítimas judias morreram como mártires. Soloveitchik não se pronunciou a respeito. 
Ocultamento da Face - Os três rabinos concordam entre si que Deus "ocultou Sua face" do povo judeu no Holocausto. Mas há uma discordância significativa: Soloveitchik considera Ocultamento da Face como um castigo divino contra pecadores, implicando que a Shoá foi punição contra algum pecado do povo judeu; já Berkovits e Greenberg rejeitam esta idéia.

Livre-Arbítrio - Berkovits e Greenberg concordam que o Holocausto foi resultado da má-utilização do livre-arbítrio, um atributo concedido e garantido à humanidade por Deus. Soloveitchik não se pronunciou a respeito.

Significado da História - Soloveitchik e Berkovits concordam entre si quando afirmam que Deus tem controle sobre a História, incluindo um evento dramático como o Holocausto. Greenberg enfatiza o papel de povo-testemunha dos judeus na História.

Por Causa de Nossos Pecados - Berkovits e Greenberg rejeitam a idéia de que o Holocausto tenha sido um castigo divino por algum pecado cometido pelo povo judeu. Já Soloveitchik, embora não explicitamente, indicou que a Shoá foi punição divina por pecado.

Jó - Berkovits e Greenberg concordam entre si quando afirmam que, assim como Jó, também o povo judeu sofreu no Holocausto apesar de ser inocente. Já Soloveitchik trata Jó de forma bastante diferente: o personagem bíblico foi um pecador que mereceu castigo, e sua trajetória ensina que o sofrimento purifica a alma.

Significado Religioso do Estado de Israel - Os três rabinos divergem entre si neste ponto. Para Soloveitchik, a fundação do país foi um evento guiado por Deus, mas não faz parte do processo messiânico; Berkovits concorda que o evento foi guiado por Deus, mas diverge do primeiro ao afirmar seu caráter messiânico. Já Greenberg, que percebe religiosidade e messianismo no evento, enfatiza muito mais a atuação humana. 
Singularidade do Holocausto - Berkovits e Greenberg discordam neste ponto: o primeiro afirma que o Holocausto não foi um evento único, enquanto o segundo afirma o oposto. Soloveitchik não se pronunciou diretamente sobre o assunto.

Como conclusão, podemos afirmar que os três pensadores não concordaram plenamente entre si sobre nenhum dos nove conceitos e temas que aplicaram para o caso do Holocausto.

O único caso em que se aproximaram de um consenso é quando trataram do conceito de História como Revelação Divina, mas mesmo aqui, Greenberg desenvolveu idéias que não estão presentes nas reflexões dos outros dois rabinos. Quando discorreram sobre o conceito de Ocultamento da Face, os três rabinos concordaram que "Deus ocultou Sua face do povo judeu durante o Holocausto". Mas Soloveitchik divergiu profundamente ao insinuar que isto se deveu a algum pecado do povo judeu. Quanto ao conceito de Livre-Arbítrio, Berkovits e Greenberg concordaram entre si, mas Soloveitchik não se pronunciou.

Nos demais conceitos e temas, evidencia-se ainda mais a discordância entre os rabinos. Em três casos (Aliança, Por Causa de Nossos Pecados, Jó), dois pensadores concordam entre si, enquanto o terceiro discorda. Em dois casos (Martírio e Singularidade do Holocausto), dois pensadores discordaram entre si, enquanto o terceiro não se pronuncia. Em um caso (Caráter Religioso do Estado de Israel), os três discordaram entre si.

A pergunta, então, que esta tese coloca é como explicar tamanha divergência entre membros de uma mesma corrente do judaísmo a respeito de uma questão tão importante como o Holocausto.

9 - TRÊS ELEMENTOS PARA PENSAR A CONTRADICÃO ENTRE OS

\section{RABINOS}


Como vimos acima, as reflexões de Soloveitchik, Berkovits e Greenberg sobre o Holocausto não são harmônicas entre si. Numa situação prática, um mesmo fiel, adepto da Ortodoxia Moderna, poderia entrar na sinagoga de cada um destes três rabinos e ouvir interpretações bem diferentes sobre o significado religioso da Shoá.

Esta situação não é simples. O Holocausto representou um enorme desafio ao judaísmo, levantando questões essenciais sobre a crença em Deus e no status do povo judeu. Mas quando três pensadores de uma mesma corrente judaica se propuseram a explicar à sua audiência este evento histórico sob a luz de conceitos tradicionais, não conseguiram chegar a um consenso.

Baseado nesta situação, uma questão que se levanta é se a falta de consenso entre os pensadores do Holocausto é uma anomalia na história do pensamento judaico ou se trata-se de uma condição já conhecida de outras catástrofes passadas do judaísmo. Devemos nos perguntar se as contradições entre os rabinos estaria sinalizando um abalo estrutural da religião judaica frente à Shoá ou se estas discordâncias são uma ocorrência normal e esperada.

Outra questão que surge é sobre a importância mesma das reflexões sobre o Holocausto. Se houve contradição entre os pensadores, talvez isto não represente um problema maior, no caso de todo este empreendimento ser apenas um exercício teórico de pouca significação no contexto do judaísmo.

Sabemos que o judaísmo demonstrou grande vitalidade após o Holocausto. A religião judaica floresceu tanto nos Estados Unidos, quanto no Estado de Israel e nos principais países do mundo ocidental. A conclusão de importantes pesquisadores é de que a fé do judeu comum não foi basicamente afetada pela Shoá ${ }^{747}$.

Nos EUA, como vimos mais acima ${ }^{748}$, a Ortodoxia Moderna floresceu especialmente após o Holocausto, simbolizada pela atuação do próprio Soloveitchik à frente da Yeshiva University. Outros grupos judaicos e yeshivot de outras

\footnotetext{
${ }^{747}$ Eshkoli, 2003, pg. 447.

${ }^{748}$ ver capítulo “A Ortodoxia Moderna - História e Principais Idéias”.
} 
orientações $^{749}$, ameaçados de sumiço pelo massacre nazista, também voltaram a prosperar após serem transferidos da Europa destruída.

O reerguimento do judaísmo após a Shoá ficou ainda mais patente no Estado de Israel. O estudo da Torá no país alcança níveis inéditos em toda a história judaica $^{750}$. Apoiada no sistema de Previdência israelense, surgiu uma "sociedade de eruditos", formada por um vasto contingente populacional de ortodoxos ${ }^{751}$, que dedica suas vidas exclusivamente a assuntos religiosos ${ }^{752}$, uma situação inaudita antes do Holocausto.

Após 1945, tanto em Israel quanto no Ocidente em geral, disseminou-se a instituição denominada Kolel, onde o religioso adulto continua seus estudos após sua formação numa yeshiva. O Kolel já existia na Europa Oriental antes do Holocausto, mas apenas uma pequena minoria podia se dar ao luxo de frequentá-la, numa situação bem diversa da observada na atualidade ${ }^{753}$.

A questão que se coloca é se todo este florescimento do judaísmo no pósguerra tem alguma relação com as reflexões dos pensadores judeus da Shoá. Trata-se de determinar se a Teologia do Holocausto contribuiu para o fortalecimento da religião judaica ou se representou um mero exercício intelectual marginal e sem maiores significados.

Em resumo, a desarmonia entre os pensadores do Holocausto examinados neste trabalho coloca-nos frente às seguintes questões: como entender a contradição entre três pensadores de uma mesma corrente judaica que se propuseram a enfrentar o desafio da Shoá? A sobrevivência e florescimento do judaísmo no pós-guerra está de alguma maneira ligada a estas reflexões? Qual a importância da teologia, de um modo geral, no judaísmo?

\footnotetext{
${ }^{749}$ Friedman, Al Hanisim, pg. 432.

${ }^{750}$ Ravitzky, 2001, pg. 231.

${ }^{751}$ Segundo o jornal Haaretz, 70\% dos homens ortodoxos israelenses não participam do mercado de trabalho (11/11/07, pg. 8).

${ }^{752}$ Friedman, Al Hanisim, pgs. 432 e 433.

${ }^{753}$ Friedman, Al Hanisim, pgs. 437 e 438.
} 
Esta tese pretende propor uma resposta a estas questões baseada em três elementos: a ausência de tradição teológica no judaísmo; a aceitação da diferença de opiniões no judaísmo; a importância da Literatura de Hurban. Examinemos a seguir cada um destes elementos.

\section{1 - A ausência de tradição teológica no judaísmo}

A teologia, tanto no judaísmo quanto no cristianismo, é produto da influência do pensamento grego ${ }^{754}$. Quando a cultura judaica entrou em contato com o helenismo, a partir da conquista da Terra de Israel por Alexandre o Grande em 333 a.e.c., o conceito de teologia já estava claramente definido no mundo grego ${ }^{755}$. A expressão "theologia" 756 na Grécia antiga denotava "doutrina referente a deus" ou "ciência divina" e era aplicada aos poemas de Hesíodo e Homero, que tratavam dos deuses e suas atividades. A teologia ${ }^{757}$ também já se fazia presente nas reflexões dos filósofos clássicos.

O interesse grego por teologia foi herdado primordialmente pela Igreja cristã, que passou a entendê-la como a investigação sobre o Deus bíblico e seu relacionamento com o mundo ${ }^{758}$. Teologia passou a ser ensinada em monastérios e escolas religiosas através da Europa, tornando-se um item inseparável dos deveres cristãos, ao lado do culto e da prece ${ }^{759}$. Sua difusão encontrou ${ }^{760}$ um ambiente fértil nas primeiras universidades européias surgidas no século XIII. Durante 500 anos, a disciplina foi considerada como a principal ciência, cuja palavra carregava autoridade

\footnotetext{
${ }^{754}$ De Lange, 1986, pg. 107.

755 Cohon, 1971, pgs. 5 e 6.

756 Em grego, o termo significa "deus" (theos) e "palavra, doutrina" (logos). (Jacobs, 1972, pg. 1103)

${ }^{757}$ Platão ocupou a vanguarda da teologia sistemática ao delinear os principais temas de investigação: a existência e a bondade da divindade, a realidade de sua ordem providencial no universo, a imortalidade da alma, a relação entre as ações do homem e seu destino, entre outros.

(Cohon, 1971, pgs. 5 e 6 / Kohler, 1918, pg. 1)

Em Aristóteles, a palavra teologia assumiu pela primeira vez sua característica técnica. O pensador derivou da ordem do mundo três filosofias teóricas: matemática, física e teologia. Por teologia, que ocupava a posição mais proeminente em seu sistema, designou o que chamamos de metafísica, que alcançou seu clímax na especulação sobre a natureza de deus como Primeira Causa.

(Cohon, 1971, pgs. 6)

${ }^{758}$ De Lange, 1986, pg. 107.

${ }^{759}$ Ford, 2005, pg. 63.

${ }^{760}$ Ford, 2005, pgs. 64 a 66.
} 
para as demais faculdades. Foi somente com o Iluminismo que esta influência declinou $^{761}$.

Teologia, no mundo ocidental cristão, é definida como a exposição sistemática de uma fé conforme um método lógico ${ }^{762}$, onde princípios religiosos são delineados e clarificados ${ }^{763}$. Entre os tópicos abordados pela reflexão teológica ${ }^{764}$ estão providência divina, reza, culto, pecado, livre-arbítrio, arrependimento, teodicéia, imortalidade e angeologia.

A teologia, definida desta maneira, não é encontrada no judaísmo durante sua fase bíblica. A Bíblia Hebraica ${ }^{765}$ não traz nenhum tratamento sistemático de problemas teológicos típicos. Mostra disto é não encontramos nas Escrituras ${ }^{766}$ palavras em hebraico para termos característicos da reflexão teológica, como religião, unidade divina, providência, revelação, retribuição, ressurreição, imortalidade, ética, moralidade ou virtude.

Nenhum dos autores da Bíblia Hebraica duvidou da existência de Deus, mas eles não se preocuparam em prová-la ou explorá-la ${ }^{767}$. Apesar da divindade ${ }^{768}$ ser um tema central nas Escrituras, não se encontra ali especulações sobre sua natureza. Por exemplo, a Bíblia afirma que nada é impossível para Deus ${ }^{769}$, mas isto não é seguido das discussões típícas da teologia medieval sobre a possibilidade da divindade realizar até o logicamente impossível.

A ausência de teologia na Bíblia Hebraica é uma constatação natural ${ }^{770}$, se levarmos em consideração a distância de seus autores em relação ao pensamento grego. Foi apenas no crepúsculo da era bíblica, com a irresistível penetração do helenismo em todo o Oriente Médio antigo, que começaram a surgir as primeiros

\footnotetext{
${ }^{761}$ Chegando à situação atual nas universidades ocidentais, onde a teologia ocupa uma faculdade no mesmo nível das demais ou nem é mais ensinada.

${ }^{762}$ Kohler, 1918, pg. 1.

${ }^{763}$ Mendes-Flohr, 2002, pg. 763.

${ }^{764}$ Jacobs, 1972, pg. 1103.

${ }^{765}$ Jacobs, 1972, pgs. 1104 e 1105.

${ }^{766}$ Cohon, 1971, pg. 8.

${ }^{767}$ De Lange, 1986, pg. 107.

${ }^{768}$ Jacobs, 1972, pgs. 1104 e 1105.

769 “Acaso para o Senhor há coisa demasiadamente difícil?" (Gn 18:14), "Eis que Eu sou o Senhor, o Deus de todos os viventes; acaso haveria coisa demasiadamente maravilhosa para mim?" (Jr 32:27).

${ }^{770}$ Jacobs, 1972, pg. 1105.
} 
teólogos judeus. O mais destacado deles foi Filo (circa 15 a.e.c - 50 e.c.), que viveu na cidade egípcia de Alexandria. Porém, suas reflexões originais sobre as Escrituras, que tiveram considerável impacto sobre o pensamento cristão nascente, foram ignoradas pelo judaísmo rabínico pós-bíblico ${ }^{771}$.

Durante quase mil anos, os rabinos não produziram reflexões que possam ser classificadas como teologia ${ }^{772}$. Na Mishnah, no Talmud, nos midrashim e em outras obras rabínicas do período inexiste um corpo de doutrinas articulado e sistematizado $^{773}$, nem um cuidado em clarificar e definir princípios básicos da fé ${ }^{774}$.

O que mais poderia se aproximar de teologia na literatura rabínica são as agadot. Estes textos tratam de Deus, anjos, Criação, ordem do mundo, revelação, mérito, graça, escatologia, retribuição, messias, entre outros temas tipicamente teológicos. Ali também pode ser encontrado um corpo razoavelmente uniforme de opiniões e um painel das principais linhas de especulação do judaísmo rabínico ${ }^{775}$.

Porém ${ }^{776}$, por sua própria característica, a agadah dificilmente pode ser considerada pura reflexão teológica. Esta literatura ${ }^{777}$, constituída em sua maior parte de sermões de rabinos elaborados para edificar o público, traz em seu corpo uma grande liberdade criativa e pouca precisão do tipo escolástica. As agadot ${ }^{778}$ são frequentemente vagas, nebulosas e cheias de contradições. O mais correto ${ }^{779}$ seria considerá-las como uma forma rabínica original de especulação, mas bem diferente do pensamento teológico grego ou cristão ${ }^{780}$.

\footnotetext{
${ }_{771}^{772}$ Jacobs, 1972, pg. 1105 / Cohon, 1971, pg. 8.

${ }^{772}$ Uma das explicações para a ausência de teologia no pensamento rabínico é a reação ao ambiente externo. Disputas amargas com o cristianismo nas épocas apostólica e patrística levaram a uma relutância cada vez maior dos rabinos em se engajar em debates e confrontações do tipo teológica (Cohen, 1987, pg. 973). Desta forma, a suspeita rabínica em relação à teologia pode ser entendida como a reação de uma minoria frente a uma religião (cristianismo) marcadamente teológica e vista como opressiva (Ford, 2005, pg. 73). Adicionado a isto, parece ter havido um desejo deliberado dos rabinos em não confundir o método especulativo judaico com o dos cristãos (Cohen, 1987, pg. 972).

${ }^{773}$ Jacobs, 1972, pg. 1105.

${ }^{774}$ Cohen, 1987, pg. 973.

${ }^{775}$ Cohon, 1971, pg. 44.

${ }^{776}$ Cohen, 1987, pg. 972.

777 Jacobs, 1972, pg. 1105.

${ }^{778}$ Cohon, 1971, pg. 44.

${ }^{779}$ Cohen, 1987, pg. 972.

${ }^{780}$ A precisão e o rigor presentes nas obras cristãs de teologia têm seu paralelo rabínico apenas nos textos de halakhah produzidos no mesmo período. Aqui, no desenvolvimento de leis religiosas para a
} 
Esta posição marginal da teologia no judaísmo somente foi modificada na Idade Média, sob o impacto do encontro judaico com a cultura islâmica. Vivendo como minoria no império árabe, os judeus sefaradim foram influenciados pela valorização da filosofia grega neste ambiente intelectual. Foi nesse período ${ }^{781}$ que a teologia judaica realmente nasceu, com o aparecimento do primeiro teólogo judeu de importância, o egípcio Saadia ben Joseph (882-942), o Saadia Gaon, com sua obra Emunot Ve-Deot, e que foi seguido de muitos outros ${ }^{782}$. O próprio termo "teologia" recebeu, enfim, equivalentes hebraicos ${ }^{783}$.

Porém, o judaísmo sefaradi ${ }^{784}$ nunca conseguiu inserir o interesse pela teologia no mainstream do pensamento rabínico. Os importantes centros ashkenazim na França e Alemanha reagiram com hostilidade a todo este racionalismo e continuaram imunes à reflexão teológica. Com a Reconquista cristã da Península Ibérica e a consequente decadência da cultura sefaradi, a atitude anti-racionalista tornou-se dominante e normativa no judaísmo, que passou a ser caracterizado pelo estudo do Talmud com foco na halakhah.

A teologia judaica adormeceu pelos quatro séculos seguintes, até seu despertar no contexto do Iluminismo judaico ${ }^{785}$. Mais uma vez, o interesse dos judeus pela teologia foi estimulado por influência externa, desta vez o ambiente cultural ocidental cristão. Moses Mendelssohn (1729-1786), iniciador do movimento de abertura do

comunidade, os rabinos aplicaram toda sua energia e capacidade intelectual. Desta maneira, diferentemente do cristianismo, pode-se afirmar que o judaísmo pós-bíblico se preocupou "mais com o que Deus quer dos homens do que o que é Deus" (Jacobs, 1972, pg. 1103).

(Jacobs, 1973, pg. 10 / Gillman, 1990, pg. 215 / Eisen, 1996, pg. 151 / Cohon, 1971, pg. 44 / Cohen, 1987, pg. 971 / Jacobs, 1972, pg. 1103 e 1105 / De Lange, 1986, pg. 108)

781 Jacobs, 1972, pg. 1106 / De Lange, 1986, pg. 110 / Cohon, 1971, pg. 9.

782 Especialmente Yehuda Ha-Levi (1075-1141), autor de Sefer Ha-Kuzari (Livro do Kuzari), e Maimônides. Este último desenvolveu teologia em todas as suas obras, com exceção de seus textos médicos, destacando-se More Nevuchim (Guia dos Perplexos) e Mishne Tora (A Torá Revista). Além destes dois teólogos, deve-se mencionar Bahya ibn Paquda, Abraham ibn Daud, Levi Gershom, Hasdai Crescas, Isaac Arama, Isaac Abrabanel, Joseph Jabez e Moses di Trani.

(Jacobs, 1972, pg. 1106).

${ }_{783}$ Elohiut (ou HaElohiut), Limud Elohi, Hakhma Elohit, Madah HaElohi, Torat Haelohut (Cohon, 1971, pg. 9).

${ }^{784}$ De Lange, 1986, pgs. 116 e 117.

${ }^{785}$ De Lange, 1986, pg. 118. 
judaísmo na Alemanha, escreveu teologia ${ }^{786} \mathrm{e}$, desde então, esta disciplina passou a fazer parte integral do pensamento judaico no mundo ocidental.

A teologia judaica floresceu no século XIX, principalmente na Alemanha ${ }^{787} \mathrm{e}$, em particular, entre os pensadores da Reforma ${ }^{788}$, que se sentiram impelidos a apresentar racionalmente suas novas posições e diferenciá-las tanto do judaísmo tradicional quanto do cristianismo. O líder reformista Abraham Geiger (1810-1874) fundou a "Revista Científica de Teologia Judaica", que atraiu colaboradores de toda a Europa. Como consequência, também pensadores ortodoxos judeus, que faziam oposição à Reforma, foram obrigados a tratar questões teológicas com seriedade.

A primeira metade do século XX, até o Holocausto, testemunhou uma profusão de teólogos judeus, com destaque para Martin Buber, Franz Rosenzweig, Mordecai Kaplan, Leo Baeck e Abraham Heschel ${ }^{789}$.

A partir da exposição acima, poder-se-ia concluir que reflexões como as de Soloveitchik, Berkovits e Greenberg, assim como toda a Teologia Judaica do Holocausto, é um fenômeno recente e marginal no judaísmo. Nos três mil anos de desenvolvimento da religião judaica, a teologia apenas se fez presente na Idade Média entre os sefaradim e na Idade Moderna entre os não-ortodoxos tradicionais. Digno de nota, a teologia está ausente nas obras cardinais do judaísmo, como a Bíblia Hebraica, a Mishnah e o Talmud.

Se não há uma tradição de teologia no judaísmo, deveríamos esperar de rabinos que se dedicam à chamada Teologia do Holocausto um alto grau de desenvolvimento, coerência e sofisticação? Poderíamos desculpar os três pensadores

\footnotetext{
${ }^{786}$ Jacobs, 1972, pg. 1108.

787 Entre eles, Abraham Geiger, Zacharias Frankel, Leopol Zunz, Nachman Krochmal, Solomon Steinheim, Samuel Hirsch, Solomon Formstecher, Samson Raphael Hirsch e Hermann Cohen (Jacobs, 1972, pg. 1108.)

${ }^{788}$ Mendes-Flohr, 2002, pg. 764 / Jacobs, 1972, pg. 1109.

${ }^{789}$ Gillman, 1990, pg. 216 / Jacobs, 1972, pg. 1109 / De Lange, 1986, pg. 121.
} 
pela falta de harmonia entre suas reflexões por se tratar de um campo pouco desenvolvido no judaísmo?

Ou talvez, alternativamente, deveríamos classificar as reflexões rabínicas sobre o Holocausto de outra maneira, e não como "teologia" ? Haveria alguma outra tradição judaica, mais consistente, onde se pudesse inserir estas reflexões e entendêlas melhor?

\section{2 - A aceitação da diferença de opiniões no judaísmo}

Uma das características mais marcantes da literatura rabínica é a presença de controvérsias ${ }^{790}$ em seu corpo. A Mishnah, o Talmud e obras posteriores estão repletas de debates entre os rabinos sobre virtualmente todo assunto que é levantado. Algumas destas controvérsias são resolvidas, outras são deixadas sem resolução ${ }^{791}$.

Controvérsias estão fortemente presentes no próprio coração do judaísmo rabínico, a halakhah. Como norma, a fim de promulgar leis religiosas para a comunidade, a elite entre os rabinos reunia-se, trocava idéias entre si e chegava eventualmente a um acordo. Porém, em algumas situações, não havia consenso ou várias opiniões pareciam igualmente aceitáveis. Instaurava-se, então, uma controvérsia $^{792}$.

Nesta situação, a mesma elite rabínica organizava uma votação e solucionava a disputa de acordo com a opinião da maioria, que deveria ser aceita por toda a comunidade ${ }^{793}$. A regra-de-ouro do judaísmo rabínico sempre foi tolerar o debate no

\footnotetext{
${ }^{790}$ Em hebraico, mahloket ou מחלוקת (pl. Mahlokot מחלוקות). Em português, a palavra pode ser traduzida por "controvérsia, disputa, diferença de opiniões, divisão".

${ }^{791}$ Ben-Menahem, 2005, pgs. 2 e 6.

${ }^{792}$ Ben-Menahem, 2005, pgs. 2 e 6.

${ }^{793} \mathrm{O}$ conceito de que a maioria é que determina a halakhah, bem como o caráter multi-facetado da lei judaica, está presente num midrash rabínico sobre o capítulo 12 do Livro de Salmos (Midrash Tehillim):

“'As palavras do Senhor são palavras puras, prata refinada em cadinho de barro, depurada sete vezes (Salmo 12:6)'. Rabi Yannai disse (interpretou este versículo): os estatutos da Torá não foram dadas como [éditos] nítidos. Pois cada estatuto que o Santo transmitiu a Moisés, Ele ofereceu 49 (o midrash aqui interpreta "sete vezes" do Salmo como sendo sete vezes sete) razões para declarar 'puro' e 49 razões para declarar 'impuro'. [Moisés então] disse a Ele: 'Mestre do Universo, como saberemos o
} 
plano teórico, mas ao mesmo tempo exigir total sujeição do fiel à autoridade religiosa no plano da prática ${ }^{794}$.

Deve-se notar que a tolerância pela diferença de opiniões não foi uma total novidade introduzida pelos rabinos no judaísmo. A Bíblia Hebraica ${ }^{795}$ já trazia em seu interior visões conflitantes sobre um mesmo tema. Porém, estas divergências aparecem em capítulos e livros bíblicos diferentes, não em oposição direta. Já na literatura rabínica, opiniões conflitantes foram canonizadas lado-a-lado.

A Mishnah, a primeira obra-prima do judaísmo rabínico, traz incontáveis controvérsias em seu corpo ${ }^{796}$. As mais célebres envolvem duas escolas de pensamento, uma ligada ao fariseu Hillel e outra ao fariseu Shammai ${ }^{797}$. Após a destruição do Segundo Templo de Jerusalém, no ano $70{ }^{798}$, a liderança rabínica

sentido real de uma lei?'. Ele respondeu: 'Siga a maioria'. Se a maioria decidir 'impuro', é impuro; se a maioria decidir 'puro', é puro." (citado in Walzer, 2000, pg. 317).

Uma passagem da Tosefta, Tratado Sanhedrin 7:1, retrata o processo de decisão na época do Segundo Templo de Jerusalém, com a maioria decidindo a halakhah:

"Rabi Yosi disse: (...) se alguém precisava saber uma questão de halakhah, ía à corte rabínica de sua cidade; se não havia corte em sua cidade, dirigia-se à corte da cidade mais próxima. Se sabiam a halakhah, informavam-no; se não sabiam, o indivíduo e o membro mais ilustre daquela corte dirigiamse à corte que ficava no Monte do Templo. [Lá,] se sabiam a halakhah, informavam-lhes; se não (...) iam à corte localizada na Muralha (uma certa localidade no próprio Monte do Templo; em hebraico, חיל). [Lá,] se sabiam a halakhah, informavam-lhes; se não (...) iam à Suprema Corte localizada na Pedra-de-Granito (também localizada no Monte do Templo; em hebraico, בית דין הגדול שבלשכת הגזית.) (...). Lá, [os sábios] se reuniam (...) se tinham uma resposta para a questão levada a eles, informavam. Se não, votavam. [Se] os que consideravam 'impuro' eram maioria, declaravam o resultado da questão como sendo 'impuro'. [Se] os que consideravam 'puro' eram maioria, declaravam o resultado como sendo 'puro'. Dali a halakhah era difundida e circulava em Israel'.

${ }^{794}$ Ben-Menahem, 2005, pg. 19.

${ }^{795}$ Halbertal, 1997, pg. 45.

Sobre a monarquia, comparar visões desfavoráveis em Jz 8:23 e 1Sm 8:4 a 7 com visões favoráveis em Jz 21:25 e 19:1. Sobre a criação da mulher, comparar Gn 1:27 com Gn 2:21 e 22. Sobre o casamento com moabitas, comparar proibição em Dt 23:4 e Ne 13:23 e.d. com tolerância em Rt 1:1 a 4. Sobre "não seguir o coração e os olhos", comparar Nm 15:39 com Ecl 11:9.

${ }^{796}$ Um exemplo está no Tratado Berakhot 8:1 a 5 da Mishna:

"Estas são as diferentes visões entre a Escola de Shammai e a Escola de Hillel quanto a refeições. A Escola de Shammai diz: [No shabat ou nas festividades] primeiro abençoa-se o dia e depois abençoase o vinho; e a Escola de Hillel diz: primeiro abençoa-se o vinho e depois o dia. A Escola de Shammai diz: lava-se as mãos e depois enche-se a taça [de vinho para a benção]; e a Escola de Hillel diz: enchese a taça e depois lava-se as mãos. A Escola de Shammai diz: seca-se as mãos com um guardanapo e coloca-o na mesa; e a Escola de Hillel diz: coloca-o na almofada (...) A Escola de Shammai diz: [a ordem das bençãos que marcam o fim do shabat é] vela, alimento, especiarias e [reza da] havdala; e a Escola de Hillel diz: vela, especiarias, alimento e havdala. A Escola de Shammai diz: [a benção sobre a vela é] she-bara meor haesh; e a Escola de Hillel diz: [a benção é] bore meorei haesh".

${ }^{797}$ Hillel e Shammai viveram entre o século I a.e.c. e o século I e.c. De uma maneira geral, embora nem sempre, a Escola de Hillel (em hebraico, beit hillel) adotava posições mais brandas que a Escola de Shammai (em hebraico, beit shammai).

${ }^{798}$ Walzer, 2000, pgs. 336 e 337. 
decidiu adotar o ensinamento da Escola de Hillel como normativo ${ }^{799}$. Porém, numa mostra da apreciação rabínica pela diferença de opiniões, o pensamento da Escola de Shammai foi fielmente preservado na Mishnah ${ }^{800}$.

Numa indicação da naturalidade da presença de controvérsias no judaísmo rabínico, o Talmud retratou o próprio Deus ocupado em debater assuntos de halakhah. Uma agadah talmúdica descreve uma mística yeshivah celestial (ישיבה של מעלה), onde a divindade e rabinos já falecidos discutem assuntos da lei, de igual para igual, sem no entanto chegar a um acordo ${ }^{801}$.

799 Uma passagem do Talmud da Babilônia - Tratado Erubin 13b - relata como a grande disputa foi
resolvida:
"Durante três anos houve uma disputa entre a Escola de Shamai e a Escola de Hillel. A primeira
afirmava: 'a halakhah é de acordo com nossa visão', enquanto a segunda sustentava: 'a halakhah é de
acordo com nossa visão'. Então uma voz divina (בול) anunciou: 'ambas são palavras do Deus vivo,
porém a halakhah é de acordo com a Escola de Hillel'." A agadah continua:

"Mas se ambas são palavras do Deus vivo, por que foi concedido à Escola de Hillel que a lei fosse estabelecida de acordo com sua visão? Porque eles eram tolerantes e mansos, e estudavam tanto suas próprias decisões quanto as da Escola de Shammai. Além disso, eles colocavam as palavras da Escola de Shammai antes de suas próprias (...) Isto ensina que aquele que se humilha, é exaltado pelo Santo [Deus], enquanto que aquele que se exalta, é humilhado pelo Santo".

Segundo apontou o professor David Shatz, a preferência por Hillel também pode ser entendida como um elogio ao debate: ao levar em conta a opinião do adversário, esta Escola mostrou-se a mais comprometida com o processo de discussão (Shatz, 2000, pgs. 341 e 342).

${ }^{800}$ Por que os rabinos decidiram canonizar tanto a opinião majoritária (vencedora) quanto a minoritária (vencida)? Para Moshe Halbertal, esta é uma questão ainda em aberto, sem uma resposta (Halbertal, 1997, pg. 50).

A própria Mishnah, num momento de auto-reflexão, perguntou-se o por quê da preservação da opinião minoritária, portanto vencidas, mas na tentativa de dar uma resposta, os rabinos entraram novamente em controvérsia. $\mathrm{O}$ Tratado Eduyot 1:4 e 5 justifica a preservação para que possam ser reavaliadas no futuro e, eventualmente, serem transformadas em opinião majoritária:

"E por que registraram a opinião de um indivíduo contra a da maioria, apesar de que a halakhah só pode ser de acordo com a opinião da maioria? Para que se uma corte rabínica [no futuro] aprovar a opinião do indivíduo, possa se basear nele, pois uma corte não pode anular a opinião de outra corte a menos que exceda tanto em sabedoria quanto em número."

Mas em seguida, em Tratado Eduyot 1:6, um outro rabino afirma que a opinião minoritária é preservada para que no futuro, se esta mesma opinião for levantada durante o debate, possa ser novamente refutada e não tratada como uma novidade:

"Disse Rabi Yehuda (...) por que registraram a opinião do indivíduo contra a da maioria, quando aquela não prevaleceu? Para que [no futuro] se alguém disser 'Eu recebi esta tradição', outro possa responder 'Você ouviu daquele indivíduo' ".

Uma passagem da Tosefta (Tratado Eduyot 1:4) reforça esta segunda visão:

"A halakhah sempre segue a opinião da maioria. A opinião [minoritária] de indivíduos foram registradas ao lado da opinião majoritária para que fossem anuladas. Rabi Yehuda diz: 'As opiniões do indivíduo são registradas junto com a da maioria apenas para que, se houver necessidade no futuro, seja possível basear-se nelas'. E os sábios dizem: 'As opiniões do indivíduo form registradas entre as da maioria para que, num discussão sobre pureza ou impureza, um disputante que mantém [que algo é] impuro de acordo com a opinião [minoritária] de Rabi Eliezer, possa ser informado: Sua tradição é de acordo com [a opinião minoritária de] Rabi Eliezer' "'.

(Halbertal, 1997, pgs. 51 e 52 / Walzer, 2000, pg. 318)

${ }^{801}$ Esta agadah do Talmud da Babilônia (Tratado Baba Metzia 86a) inicia-se com o célebre amora Rabbah bar Nahmani, chamado geralmente apenas de Rabbah (רבה), sendo perseguido pelas 
De modo geral ${ }^{802}$, os rabinos avaliaram a presença de controvérsias no debate halákhico como algo altamente positivo ${ }^{803}$. Debates eram vistos como um meio de desenvolver o intelecto, clarificar pontos da halakhah ${ }^{804}$ e garantir a continuidade de uma liderança dotada de pensamento original ${ }^{805}$. Um rabino do século XVI, Levi b.

autoridades da cidade de Pumbedita, na Babilônia, por suposta evasão de impostos. Enquanto isto acontecia, discutia-se na Yeshiva Celestial assuntos de halakhah:

"Eles debatiam na Yeshivah Celestial (ישיבה של מעלה) o seguinte: se a mancha precedeu o cabelo branco, ele (o indivíduo) é impuro; se for o contrário, ele é puro [a referência aqui são as leis da lepra, in Levítico 13:10]. Se [a ordem] é duvidosa, o Santo disse: 'É puro', enquanto que toda a Yeshiva Celestial sustentava que ele é impuro. Quem deveria decidir isto, perguntaram. Rabbah bar Nahmani decidirá, pois ele declarou: 'Eu sou prominente nas leis de lepra' (...) Um mensageiro foi enviado [a Rabbah bar Nahmani], mas o Anjo da Morte não podia se aproximar dele, porque ele não interrompia seus estudos. Enquanto isto, soprou um vento, que causou um ruído entre os arbustos, e ele imaginou ser uma tropa de soldados. 'Que eu morra', disse, 'melhor que ser entregue nas mãos do governo'. Enquanto ele morria, disse: 'Puro, puro' (...) Uma carta caiu do Céu em Pumbedita [onde se lia] 'Rabbah bar Nahmani foi chamado pela Yeshiva Celestial'”

(citado in Ben-Menahem, 2005, pgs. 18 e 19.)

${ }^{802}$ Shatz, 2000, pg. 339 / Walzer, 2000, pg. 311 / Ben-Menahem, 2005, pgs. 5, 7, 13, 23 e 24.

${ }^{803}$ O rabino Nahman ben Simhah (1772-1811), fundador da seita hassídica Bratslaver, defendeu a controvérsia baseando-se na Cabala. Para isso, utilizou a concepção cabalística elaborada por Isaac Luria, segundo a qual a pré-condição para a Criação foi o tzimtzum ("contração" ou "recuo") de Deus, que é infinito, permitindo a existência de um espaço vazio onde o mundo pôde existir:

"Controvérsia tem a qualidade de criar o mundo (...) Se todos os sábios tivessem o mesmo pensamento, não haveria lugar para criar o mundo. É apenas pela virtuosidade de suas controvérsias, quando separam-se entre si, cada um tomando uma posição, que um espaço vazio aparece entre eles (...) pois todas as plavras que cada um deles pronuncia são todas com o propósito de criar o mundo" (citado in Walzer, 2000, pgs. 361 a 365.)

${ }^{804} \mathrm{O}$ elogio ao debate está presente nesta agadah talmúdica (Tratado Baba Metzia 84a), que descreve os hábitos de estudo de Rabbi Yohanan e Rabbi Shimon ben Lakish (comumente chamado de Rish Lakish no Talmud):

"O Rabbi Shimon ben Lakish morreu e Rabbi Yohanan ficou extremanente entristecido. Os rabinos disseram: 'Quem poderia acalmar sua mente? Que Rabbi Eleazar ben Pedat (...) vá'. Ele então foi e sentou-se frente a ele; e a cada sentença pronunciada por Rabbi Yohanan, ele dizia: 'Há uma baraita que o apóia'. Ele (Rabbi Yohanan) disse: 'Você [se considera] como Ben Lakish? Quando eu afirmava a lei, Ben Lakish levantava vinte quatro objeções, para as quais eu dava vinte quatro respostas, que levavam a um maior entendimento da lei. E [tudo] que você diz é [que] há uma baraita que me apóia. Por acaso não sei que minhas opiniões são bem fundamentadas?'. Ele então continuou rasgando sua vestimenta e choramingando: 'Onde está você Ben Lakish, onde está você, Ben Lakish'. Ele chorou até que enlouqueceu. Os sábios pediram [a Deus] misericórdia e ele morreu”.

(citado in Ben-Menahem, 2005, pg. 5)

${ }^{805}$ Ben-Menahem, 2005, pg. 28.

O rabino lituano Haim de Volozhin (1749-1821), seguindo esta tradição, estimulava os alunos a debater livremente com seus mestres:

"Um estudante não deve aceitar as palavras de seu professor se tiver objeções. Às vezes o aluno pode estar certo, assim como um pequeno pedaço de madeira pode ser o início de uma grande árvore (...) Nós disputamos com nossos sagrados professores, cujos renomados livros nós estudamos. Seus corpos estão sepultados, enquanto suas almas habitam no Alto. Pela presença de seus livros em nossas casas, nossos lares tornam-se lugares de encontros com estes sábios. Nós também fomos estimulados e recebemos permissão para lutar e batalhar com suas palavras e resolver problemas que eles levantaram. E não adular ninguém, mas amar apenas verdade".

(citado in Ben-Menahem, 2005, pg. 29) 
Jacob b. Haviv, considerou como defeituosa a promulgação de uma lei numa situação onde não houve debate ${ }^{806}$.

Porém, a existência de controvérsias no corpo do judaísmo rabínico trouxe consequências negativas. Os rabinos sofreram ataques externos, especialmente da dissidência karaíta, que apontou a presença marcante de debates como prova de inautenticidade ${ }^{807}$. Controvérsias também ${ }^{808}$ levantavam problemas teológicos sobre a verdade absoluta, facilitavam o surgimento de animosidades no interior da comunidade e, numa situação de exílio e falta de autoridade central, ameaçavam instaurar caos entre comunidades judaicas vivendo distantes umas das outras ${ }^{809}$.

Daí ter também surgido no judaísmo, embora sempre em minoria, uma ala desfavorável ao debate e às controvérsias ${ }^{810}$. Estes rabinos viam no insucesso em se chegar a um consenso sobre a halakhah um fato lamentável ${ }^{811}$. Este sentimento encontra-se pronunciado entre os geonim, a geração de rabinos pós-Talmud. Em seus

806 "Mas quando o consenso da maioria é estabelecido sem uma deliberação onde todas as partes se envolveram, [isto] não é considerado consenso de nenhuma maneira. Pois, talvez, se a maioria tivesse ouvido os argumentos da minoria, poderiam ter cedido e mudado de opinião".

(citado in Ben-Menahem, 2005, pg. 6.)

${ }^{807}$ Halbertal, 1997, pg. 46 / Ben-Menahem, 2005, pgs. 3 e 18

${ }^{808}$ Ben-Menahem, 2005, pgs. 10, 11, 12 e 13.

${ }^{809}$ Para diminuir o impacto da controvérsia, a tradição rabínica estabeleceu algumas regras para limitar sua extensão. Uma delas é a idéia de uma hierarquia entre os debatedores. As gerações mais antigas eram consideradas superiores e suas opiniões não poderiam ser disputadas. Assim, por exemplo, um rabino do Talmud não poderia contradizer um rabino da Mishnah.

Outra medida foi desencorajar a multiplicação de controvérsias desnecessárias, especialmente se ligadas a um desejo egocêntrico de auto-promoção dentro da comunidade de eruditos.

(Ben-Menahem, 2005, pgs. 28, 29 e 30)

No final das contas, o judaísmo rabínico sobreviveu durante dois mil anos, apesar das controvérsias. A halakhah permaneceu mais ou menos a mesma por toda a diáspora e eventuais desacordos foram contidos com sucesso. Para Michael Walzer, colaborou o fato de diferentes cortes rabínicas, em diferentes países, discordarem sobre textos comuns e atuarem dentro de uma mesma tradição. Mas para ele, o sucesso do rabinismo nestas condições permanece um "mistério".

(Walzer, 2000, pgs. 314 e 315)

${ }^{810}$ Ben-Menahem, 2005, pgs. 7 e 13.

${ }^{811}$ Esta visão está representada na Tosefta, Tratado Sanhedrin 7:1, onde o passado distante é descrito como um tempo ideal, sem controvérsias:

"Disse Rabi Yosi: No início, não havia controvérsias em Israel (e as disputas concentravam-se apenas nas instâncias de decisões rabínicas) (...) Quando multiplicaram-se os discípulos de Shammai e Hillel que não serviram seus mestres como seria necessário, as controvérsias em Israel tornaram-se muitas". Também uma passagem da Mishna, Tratado Eduyot 8:7, descreve a era messiânica como uma época ideal, sem controvérsias:

"Rabi Yehoshua disse: Recebi uma tradição de Raban Yochanan ben Zakai, que escutou de seu mestre, e seu mestre de seu mestre, como uma lei dada a Moisés no Sinai, que Eliahu * (..) virá (...) Rabi Yehuda diz: '[virá] para reconciliar as controvérsias'”

* o profeta Eliahu (ou Elias) inaugurará a era messiânica, segundo Malaquias 4:5.

(Ben-Menahem, 2005, pgs. 33 e 34.) 
escritos, tentaram resolver de forma inequívoca as disputas halákhicas, numa atitude contrária ao espirito talmúdico ${ }^{812}$.

O mais célebre oponente das controvérsias foi Maimônides ${ }^{813}$. Sua obraprima de halakhah, Mishne Tora, é um compêndio de leis judaicas elaborado com a finalidade explícita de acabar de vez com todas as disputas entre os rabinos. Novidade no judaísmo até então, a obra apresenta ao leitor as halakhot desvinculadas das controvérsias e visões alternativas típicas da Mishnah e do Talmud ${ }^{814}$.

Apesar da Mishne Tora ter se tornado uma obra fundamental do judaísmo, sua posição anti-controvérsia foi rechaçada logo de início. O rabino Abraham ibn Daud, contemporâneo de Maimônides, criticou-o severamente por isso ${ }^{815}$. Numa verdadeira

${ }^{812}$ Ben-Menahem, 2005, pgs. 34 e 35.

813 Durante a Idade Média judaica, três rabinos destacados - Maimônides, Abraham ibn Daud e Nachmânides - apresentaram modelos explanatórios diferentes e conflituosos entre si sobre a presença de controvérsias na tradição rabínica.

No modelo "cumulativo" de Maimônides, cada geração de rabinos foi vista como adicionando novas halakhot à tradição recebida de Moisés, através de raciocínio dedutivo. Maimônides foi o primeiro a afirmar que os sábios da Mishnah introduziram novas interpretações à Torá de sua própria criação. Segundo ele, controvérsias surgiriam apenas a respeito de halakhot novas, pois as regras de dedução rabínicas não eram estritamente lógicas.

No modelo de "restauração" de Abraham ibn Daud, Moisés teria recebido toda a halakhah no Monte Sinai de forma perfeita. Mas durante sua transmissão às gerações seguintes, através de uma corrente de sábios, este conhecimento começou a se perder, por conta do descuido, da tendência ao esquecimento e de situações políticas desfavoráveis. Daí a essencialidade do raciocínio rabínico, que deve se esforçar para restaurar as partes perdidas do corpo de conhecimento.

O terceiro modelo é o "Constitutivo", de Moshe ben Nachman, o Nachmânides, e seus discípulos. Para eles, o raciocínio rabínico não restaura um conhecimento perdido (Ibn Daud), nem deriva novas normas (Maimônides), mas sim constitui a própria norma. Cortes rabínicas nunca se equivocam em assuntos de halakhah e por isso a comunidade deve obedecer a todas as decisões legais, mesmo se disserem "que a direita é esquerda, e que a esquerda é direita". Não há uma "esquerda" ou "direita" a priori, as cortes rabínicas é que decidem isto. Segundo este modelo, a controvérsia já estava enraizada na própria estrutura da Revelação. No Monte Sinai, Moisés não recebeu um corpo de conhecimento completo e final, mas sim, aberto, incluindo todas as futuras controvérsias. Ele passou adiante um conhecimento multi-facetado, que as gerações seguintes deveriam transformar em normas nítidas.

(Halbertal, 1997, pgs. 54, 60, 61, 63 e 64.)

${ }^{814}$ Walzer, 2000, pg. 315 / Ben-Menahem, 2005, pg. 35.

Na Introdução ao "Mishne Tora", Maimônides explicou sua intenção:

"Eu, Moisés, filho do rabino Maimon (...) considerei todos estes livros (a literatura rabínica produzida até então) e resolvi compilar o que emerge de todas estas obras, no que diz respeito ao proibido e ao permitido, o impuro e o puro, bem como outras categorias da Torá, tudo em linguagem clara e em estilo econômico, para que a Torá Oral, em sua totalidade, possa ser ordenada nos lábios de todos, livre de impulsos dialéticos, sem uma autoridade dizendo isto e outra aquilo (...) Em suma, para que uma pessoa não tenha necessidade de nenhum outro livro sobre qualquer uma das leis de Israel (...) uma pessoa pode primeiramente ler a Torá Escrita e depois ler esta [obra] e saberá toda a Torá Oral”.

(citado in Walzer, 2000, pgs. 355 e 356)

815 "Ele pretendeu melhorar, mas não melhorou, pois ele abandonou a maneira de todos os autores que o precederam. Eles sempre forneciam provas para suas afirmações e citavam autoridades para cada afirmação (...) Além disso, há assuntos sobre os quais os Geonim discordaram e este autor 
"revanche" da tradição, a Mishne Tora passou a ser ela mesma objeto de debates entre os rabinos - o próprio Ibn Daud escreveu um famoso comentário. Atualmente, a obra de Maimônides é impressa acompanhada de exegeses de diferentes rabinos ${ }^{816}$.

A partir da exposição acima, conclui-se que a existência de opiniões conflitantes e de controvérsias entre rabinos não é sinal de fraqueza na concepção judaica. Pelo contrário, o debate, mesmo se finalizado sem uma conclusão clara, é visto como uma situação normal e até desejável.

Poderíamos transferir esta conclusão para as reflexões de Soloveitchik, Berkovits e Greenberg e explicar a diferença de opiniões entre os três rabinos como um saudável debate? O próprio Greenberg acredita que sim (vide Apêndice).

Assim como os rabinos da era talmúdica, os três pensadores examinados nesta tese concordam entre si a respeito das noções básicas do judaísmo: a existência de Deus, a noção de povo eleito, a sacralidade da Terra de Israel, História como Revelação Divina etc. No entanto, ao aplicar estes conceitos no caso do Holocausto, eles discordaram em larga medida.

Em suma, deveríamos aceitar a controvérsia entre os pensadores judeus do Holocausto como uma situação normal ? Seria uma mostra da inclusão destes rabinos na tradição judaica que vem pelo menos desde a Mishnah ? Ou as discordâncias entre eles seriam uma indicação do fracasso da Teologia do Holocausto ?

\section{3 - $\underline{\text { A importância da Literatura de Hurban }}$}

Os judeus, em sua longa história, experimentaram calamidades nacionais tão agudas que chegaram a abalar as bases de sua religião. Estes eventos históricos são chamados de hurban (חורבן), uma palavra hebraica que pode ser traduzida como

(Maimônides) selecionou uma das opiniões e a incorporou em seu compêndio. Por que eu deveria confiar em sua escolha (...) ?"

(citado in Walzer, 2000, pgs. 356 e 357)

${ }^{816}$ Walzer, 2000, pgs. 315, 356 e 357. 
“catástrofe, destruição, desolação, ruína”. Um hurban não é medido apenas pela quantidade de mortos ou destruição material, mas principalmente pelo dano crítico às estruturas do judaísmo ${ }^{817}$.

Os principais hurbanot da histórica judaica ${ }^{818}$ foram a destruição do Primeiro Templo de Jerusalém pelos babilônios (586 a.e.c.), a destruição do Segundo Templo pelos romanos (ano 70), o fracasso da Revolta de Bar-Kochba (135), o massacre das comunidades judaicas da Alemanha e França pelos cruzados (1096), a Expulsão da Espanha (1492), a destruição do judaísmo da Europa Oriental durante a revolta cossaca de Bogdan Chmielnicki (1648-49) e o Holocausto nazista (1933-1945).

Nestes eventos, dogmas básicos do judaísmo, tais como a preocupação de Deus pelos assuntos humanos ou o status dos judeus como povo eleito, foram colocados em xeque. Para garantir a sobrevivência do judaísmo após um hurban, pensadores judeus tiveram que reestruturar e até transformar paradigmas da religião até então aceitos ${ }^{819}$. Examinemos, a seguir, as circunstâncias destes hurbanot e suas consequências.

\section{A) Destruição do Primeiro Templo de Jerusalém (586 a.e.c.)}

Sabemos, através da Bíblia Hebraica, que nos séculos que antecederam este hurban, durante o período monárquico de Judá, a fé israelita girava em torno de dois dogmas fundamentais: a capital do reino, Jerusalém, era tida como a morada de Deus na Terra e acreditava-se na eternidade da dinastia real, formada por descendentes de Davi $^{820}$.

O hurban promovido pelo império babilônico atacou diretamente estes dois dogmas: Jerusalém e seu Templo foram incendiados (2Reis 25:9) e o último rei da dinastia de Davi, Sedecias, foi humilhado e condenado ao exílio (2Reis 25:7). O

\footnotetext{
${ }^{817}$ Mintz, 1987, pg. 41 / Schweid, 1994, pgs. 300 e 301.

818 Mintz, 1984, pg. 102 / Roskies, 1984, pg. 41.

${ }^{819}$ Mintz, 1987, pgs. x, 2 e 41.

${ }^{820}$ A idéia está presente especialmente nos Salmos Reais (S1 2, 18, 20, 21, 45, 72, 89, 101, 110, 132, 144:1 a 11), no oráculo do profeta Natã (2Sm 7:4 a 17) e no poema de 2Sm 23:1 a 7.

Bright, 2000, pgs. 224, 225, 227, 288 e 289 / Mintz, 1984, pgs. 20 e 21.
} 
hurban levou a fé israelita a uma aguda crise ${ }^{821}$, que podemos vislumbrar, através do próprio texto bíblico, com indivíduos rechaçando a fé tradicional ${ }^{822}$, questionando a justiça divina ${ }^{823}$ e concluindo que a Aliança chegara ao fim $^{824}$.

O livro bíblico Lamentações, escrito logo após a queda de Jerusalém, traz a angústia e perplexidade que seguiram este hurban. A obra é marcada pela estupefação, medo de rejeição do Deus que está silencioso, experiência de abandono acompanhada de horror pela destruição e desorientação por uma situação que não fazia sentido ${ }^{825}$.

Dado o ineditismo traumático do hurban ${ }^{826}$, os autores de Lamentações demonstraram dificuldade em encontrar elementos de linguagem para retratar a catástrofe. No capítulo 2 do livro ${ }^{827}$, o autor procura uma imagem que seja compatível à situação vivida pelos sobreviventes, a fim de consolá-los. Ele acredita que, se achasse uma metáfora adequada, a angústia seria aliviada. Porém, a incomensurabilidade do hurban impede-o. Por ser sem precedentes, o hurban não permitia comparações.

\footnotetext{
${ }^{821}$ Bright, 2000, pgs. 331, 332, 333 e 348.

822 "Seremos como as nações, como as outras gerações da terra, servindo às árvores e às pedras" (Ez 20:32).

${ }_{823}$ "No entanto dizeis: o caminho do Senhor não é direito" (Ez 18:25); "nossos pais pecaram e já não existem, nós é que levamos o castigo das suas iniquidades" ( $\operatorname{Lm} 5: 7$ ).

824 "Tornamo-nos como aqueles sobre quem Tu nunca dominaste e como os que nunca se chamaram pelo Teu nome" (Is 63:19); "Visto que as nossas prevaricações e os nossos pecados estão sobre nós, e nós desfalecemos neles, como pois viveremos?" (Ez 33:10); "Eis que dizem: os nossos ossos secaram e pereceu nossa esperança, estamos de todo exterminados" (Ez 37:11).

${ }_{825}$ Cohen, 1982, pg. 36 / Mintz, 1984, pgs. 3, 20, 21 e 41 / Mintz, 1987, pg. 42.

${ }^{826}$ Mintz, 1984, pgs 22 e 29.

827 "Que poderei dizer-te? A quem te compararei, é filha de Jerusalém? A quem te assemelharei, para te consolar a ti, ó virgem filha de Sion? Porque grande como o mar é a tua calamidade; quem te acudirá?" (Lm 2:13)
} 
Como vimos mais acima ${ }^{828}$, foram os profetas clássicos ${ }^{829}$ os responsáveis por elaborar uma resposta teológica à altura do desafio do hurban e, assim, garantir a sobrevivência do judaísmo. De uma maneira geral, pode-se dizer que os profetas responderam à catástrofe justificando-a como um castigo divino pela transgressão iseraelita dos mandamentos ordenados na Aliança de Moisés. Os profetas não descartaram a Aliança de Davi e suas promessas, mas projetaram-nas para um futuro longínquo, quando a nação arrependida e purificada veria a volta da dinastia davídica e a reconstrução de sua capital.

Admiravelmente, o judaísmo bíblico sobrepujou este hurban e sobreviveu ao duro teste. Mas esta religião nunca mais seria a mesma. Uma nova comunidade emergiu no exílio, desta vez centrada em forte aderência à lei e à pureza ritual. $\mathrm{O}$ hurban também teve como consequência estimular a redação e edição de vários livros da Bíblia Hebraica, num período extremamente criativo, durante o exílio na Babilônia $^{830}$.

Ao modificar radicalmente a situação social dos judeus, o hurban também trouxe transformações no plano religioso. A maior parte do povo judeu vivia agora no coração do grandioso império babilônico e, para muitos, era a primeira vez que se deparavam com um centro de cultura mundial. Em comparação, Judá e sua capital pareciam uma província limitada. Frente à beleza e altivez dos templos pagãos, deve ter ocorrido a muitos se perguntar qual o lugar do Deus de Israel no concerto do mundo ${ }^{831}$.

\footnotetext{
${ }^{828}$ vide capítulo "Aliança".

${ }^{829} \mathrm{O}$ desejo de entender o hurban do Primeiro Templo também é assunto fundamental da chamada Escola Deuteronomista - os livros históricos da Bíblia que compreendem Josué, Juízes, 1 e 2 Samuel, 1 e 2 Reis. Este bloco historiográfico, editado após o hurban, justificou a queda de Jerusalém como uma punição divina contra os pecados de Judá, como vê-se exemplarmente em 2Reis 21:10 a 15 ("Então o Senhor falou por intermédio dos profetas, seus servos, dizendo: Visto que Manassés, rei de Judá, cometeu estas abominações, fazendo pior que tudo que fizeram os amorreus antes dele, e também a Judá fez pecar com os ídolos dele, assim diz o Senhor, Deus de Israel: Eis que hei de trazer tais males sobre Jerusalém e Judá, que todo o que os ouvir lhe tinirão ambos os ouvidos (...) Eliminarei Jerusalém como quem elimina a sujeira de um prato, elimina-a e o emborca. Abandonarei o resto da minha herança, entregá-lo-ei nas mãos de seus inimigos; servirá de presa e despojo para todos os seus inimigos. Porquanto fizeram o que era mau perante Mim e Me provocaram à ira, desde o dia em que seus pais saíram do Egito até ao dia de hoje").

(Neeman, 2002, pgs. 49, 56 e 57 / Finkelstein, 2001, pgs. 302,303 e 304 / Knauf, 2000, pg. 390 / Kraemer, 1995, pgs. 20 e 21 / Mintz, 1984, pg. 3)

${ }^{830}$ Bright, 2000, pgs. 349 e 350.

${ }^{831}$ Bright, 2000, pgs. 348, 354 e 355 / Mintz, 1984, pgs. 42 e 43.
} 
Coube ao Segundo Isaías ${ }^{832}$, no exílio da Babilônia, elaborar a transformação religiosa que adaptaria o judaísmo à era dos impérios. Assim como os profetas que o antecederam, ele também justificou o hurban como um castigo divino pela transgressão dos mandamentos (Is 42:24 e 25 / 48:17 a 19) e animou o povo com as promessas da Aliança de Davi (Is 49: 8 a 23).

Mas a grande inovação do Segundo Isaías ${ }^{833}$ foi dar uma nova dimensão ao monoteísmo israelita. Como apontam a maior parte dos críticos bíblicos, este profeta foi o responsável por universalizar a fé bíblica. Com ele, surgiu a percepção do Deus de Israel como a única divindade do universo (Is 40:12 a 26), perto de quem os deuses pagãos eram um nada (Is 41:21 a 24). A divindade israelita passou a ser concebida como tendo poder absoluto sobre a história mundial (Is 45:1 a 4), o governador de toda a Terra (IS 45:5 a 7) e que agora convidava todos os estrangeiros a também aceitar Seu comando (Is 56:1 a 8).

\section{B) Destruição do Segundo Templo de Jerusalém (ano 70)}

Os primeiros 200 anos da era cristã foram particularmente dolorosos para a nação judaica, com seguidas derrotas frente a Roma. No ano 66 e.c., os judeus iniciaram uma revolta suicida contra a ocupação romana, resultando na destruição do Segundo Templo de Jerusalém, quatro anos mais tarde. Pouco depois, entre os anos 115 e 117, sublevações na Diáspora colocaram um ponto final em importantes comunidades judaicas, entre eles a do Egito. Posteriormente, o relativo grau de liberdade que a população da Judéia ainda retinha foi eliminado de vez após uma nova e fracassada rebelião contra Roma, entre os anos 132-135, liderada por Shimon Bar Kokhba. Como resultado desta revolta, o quadro de hurban foi completado: o país foi devastado, a população aniquilada ou exilada e, a partir de então, proibiu-se a entrada de judeus em Jerusalém, que foi transformada em cidade pagã ${ }^{834}$.

\footnotetext{
${ }^{832}$ Bright, 2000, pg. 356.

${ }^{833}$ Bright, 2000, pg. 355 a 357.

${ }^{834}$ Schwartz, 2002, pgs. 79 e 80.
} 
A destruição da capital paralisou a religião de Israel. Era no templo, agora em ruínas, que os judeus acreditavam servir sua divindade através de sacrifícios, peregrinações e outros detalhados rituais. Também as instituições que guiavam a vida da nação a partir do santuário - o tribunal supremo Sanhedrin e seu chefe oficial, o sumo sacerdote ${ }^{835}$ - deixaram de funcionar, levando a uma total confusão.

Este hurban, que parecia sinalizar o fim do judaísmo, na realidade fez surgir uma nova fase desta religião - o judaísmo rabínico. Este foi herdeiro direto do farisaísmo, um movimento religioso popular que antes ainda da destruição do templo, já pregava que todo judeu deveria ser tão obediente aos mandamentos como era a elite sacerdotal e que todos poderiam repetir em seus lares as mesmas leis de pureza observadas no templo ${ }^{836}$. Os fariseus abriram um caminho que possibilitou ao judaísmo superar o problema da eliminação física de seu antigo centro religioso.

O sucesso dos herdeiros do farisaísmo - os rabinos - foi afirmar que nada havia mudado com a destruição de Jerusalém. O sacerdote do templo agora tinha um novo substituto, o rabino, assim como os sacrifícios rituais agora seriam substituídos pelo ritual nas sinagogas e pelo sacrifício pessoal na observância dos mandamentos. O centro religioso foi transportado de Jerusalém para a cidade de Yavne, onde o Sanhedrin foi reconvocado ${ }^{837}$, agora sob comando rabínico, logo recebendo o reconhecimento das autoridades romanas.

Mas no plano da teoria religiosa, a reação rabínica imediata ao hurban foi um quase silêncio ${ }^{838}$. Os rabinos tanaim ${ }^{839}$ não escreveram lamentos, não alimentaram fantasias apocalípticas, nem estabeleceram um dia de luto para marcar o hurban. A literatura tanaítica menciona apenas uma vez a cidade de Betar - local da última resistência de Bar Kokhba -, nunca menciona os líderes das revoltas judaicas e raramente menciona os imperadores romanos que oprimiram a população.

\footnotetext{
${ }^{835}$ Stern, 1988, pgs. 294 e.d.

${ }^{836}$ Neusner, 1974, pgs. 12 e 13.

${ }^{837}$ Safrai, 1988, pgs. 374, 376, 377.

${ }^{838}$ Cohen, 1982, pg. 18 / Kraemer, 1995, pgs. 7, 79, 96 e 99.

${ }^{839}$ Tana (תנא), pl. tanaim - do aramaico, "transmitir oralmente, estudar, ensinar". Rabinos de destaque mencionados na Mishnah ou pertencentes ao período mishnaico, ou seja, que atuaram aproximadamente entre os anos 20 e 200. O termo foi primeiramente usado no Talmud para distinguir estes mestres das autoridades posteriores, os amoraim.
} 
A principal obra judaica da época, a Mishnah, concentra ${ }^{840}$ suas energias quase que exclusivamente em assuntos de lei e exegese, tratando muito pouco de assuntos históricos. Com exceção de algumas poucas e insignificantes passagens, a Mishnah não nota a destruição do Segundo Templo.

Comentaristas modernos se dividem ao interpretar este silêncio da Mishnah. Alguns consideram que o choque e o desespero emudeceram os rabinos da época tanaítica. Outros interpretam o silêncio como uma calculada resposta rabínica ao hurban: a priorização de assuntos de exegese carregaria a mensagem de que nada mudara após a destruição do Templo e o judaísmo deveria seguir em frente, ao largo da catástrofe ${ }^{841}$.

É apenas no período amoraico (entre os anos 200 e 600) que este silêncio é quebrado ${ }^{842}$. Vivendo numa época em que o hurban já parecia pertencer a um tempo passado, os rabinos amoraim produziram inúmeros sermões sobre o significado da destruição e disseminaram histórias sobre os revoltosos judeus, sobre os rabinos que os apoiaram ou os condenaram, sobre imperadores romanos perversos e bondosos.

Este material é encontrado especialmente em Lamentações Rabbah ${ }^{843}$, uma coleção de midrashim rabínicos apresentados na forma de exegese do livro bíblico Lamentações. A obra foi compilada na Palestina, em algum momento entre os séculos V e VII, portanto bem distante do hurban.

É interessante destacar uma diferença fundamental entre o livro bíblico Lamentações e a obra rabínica Lamentações Rabbah. Escrito logo após o hurban de 586 a.e.c., o primeiro é uma obra marcada pela amargura e desespero, composta em sua maior parte por lamentos. Já Lamentações Rabbah, composta bem depois do hurban do ano 70, é uma obra mais jovial, trazendo uma forte mensagem de consolo e esperança $^{844}$.

\footnotetext{
${ }^{840}$ Kraemer, 1995, pg. 60 / Cohen, 1982, pgs. 18 e 19.

${ }^{841}$ Cohen, 1982, pgs. 18 e 19 / Kraemer, 1995, pg. 60.

${ }^{842}$ Cohen, 1982, pg. 19.

843 Também chamada Eikhah Rabbati.

${ }^{844}$ Cohen, 1982, pgs. 22,33 e 36.
} 
Uma passagem de Lamentações Rabbah traz uma reflexão interessante sobre a influência da passagem do tempo na elaboração rabínica sobre o hurban ${ }^{845}$ :

Rabi (Yehuda Ha-Nasi) costumava expôr o versículo "O Senhor devastou sem piedade” de 24 maneiras diferentes. Rabi Yohanan podia expô-la de 60 maneiras. Poderia ser que Rabi Yohanan foi maior que Rabi? Não! É que Rabi viveu mais perto do tempo da Destruição do Templo e ele a lembrava enquanto expunha e, por isso, parava para chorar e se consolar; ele então recomeçava, mas novamente chorava, consolava-se e parava. Já Rabi Yohanan, porque ele não viveu perto do tempo da Destruição do Templo, podia fazer sua exposição sem parar.

A questão levantada nesta passagem é se Yehuda Ha-Nasi, chamado simplesmente de Rabi, proeminente sábio da época tanaítica e editor da Mishnah, poderia ser superado em habilidade interpretativa por Yohanan, seu discípulo e rabino da época amoraica. Isto seria uma contradição à regra geral rabínica, segundo a qual rabinos tanaim são sempre superiores aos amoraim. A explicação de Lamentações Rabbah é a distância que cada um destes dois rabinos viveu em relação ao hurban. Rabi Yohanan, tendo vivido uma geração posterior, não estava tão sobrecarregado pelo peso da memória e podia tratar do assunto com mais tranquilidade que Yehuda Ha-Nasi ${ }^{846}$.

Já o Talmud da Babilônia, editado por volta do ano 550, apresenta dois tratamentos bem distintos para o hurban do Segundo Templo ${ }^{847}$. Numa passagem, o texto talmúdico justifica a destruição como uma punição divina contra pecados do povo judeu ${ }^{848}$. Mas em outra, a causa do hurban é explicada a partir de causas puramente humanas, estando Deus praticamente ausente ${ }^{849}$.

A presença de uma dupla - e irreconciliável - resposta talmúdica para o hurban é explicada de maneiras diferentes pelos comentaristas modernos. Para

\footnotetext{
${ }^{845}$ Citado in Mintz, 1984, pgs. 50 e 51.

${ }^{846}$ Mintz, 1984, pgs. 50 e 51.

${ }^{847}$ Kraemer, 1995, pgs. 176, 179, 180, 181, 182 / Goldenberg, 1982, pgs. 519, 520, 521 e 522.

${ }^{848}$ Tratado Yoma 9b, citado in Kraemer, 1995, pgs. 176, 179, 180, 181, 182.

${ }^{849}$ Tratado Gitt. 55b-58 a citado in Kraemer, 1995, pgs. 176, 179, 180, 181, 182.
} 
Kraemer ${ }^{850}$, isto é reflexo do espírito independente do Talmud da Babilônia, que registrou a explicação tradicional de hurban herdada dos profetas (punição divina por pecados), mas também expressa opiniões radicalmente novas (hurban como assunto meramente humano). Para Goldenberg ${ }^{851}$, os rabinos talmúdicos simplesmente estavam confusos e incertos a respeito das causas do hurban do ano 70. Eles haviam herdado dos profetas uma explicação clara sobre catástrofes nacionais, mas também tinham consciência de que este não era o melhor modo de explicar o hurban dos anos 70 e 135; ao mesmo tempo, não tinham uma explicação melhor para apresentar aos seus leitores.

C) Massacre das comunidades judaicas da Alemanha e França pelos Cruzados (ano $\underline{1096 \text { e seguintes) }}$

Em termos de perdas humanas, este hurban foi relativamente pequeno: estimase que os cruzados assassinaram cerca de 5 mil judeus no vale do Rio Reno ${ }^{852}$. Também em termos de destruição sócio-econômica, o hurban não atingiu proporções alarmantes ${ }^{853}$; após a crise, as comunidades judaicas atingidas ressurgiram, a atividade comercial foi retomada e as yeshivot locais voltaram a florescer. Porém, após o hurban de 1096, o judaísmo ${ }^{854}$ nunca mais foi o mesmo.

Os fatídicos eventos ${ }^{855}$ foram imortalizados por autores judeus através de dois tipos de literatura: piyyutim ${ }^{856}$ e crônicas, ambos produzidos para exaltar as comunidades massacradas e serem usados em rituais litúrgicos de lembrança nas sinagogas.

\footnotetext{
${ }^{850}$ Kraemer, 1995, pg. 150 e 209.

${ }^{851}$ Goldenberg, 1982, pgs. 518, 523 e 524.

${ }^{852}$ Mintz, 1984, pgs. 86 e 87. Poliakov fala em "pelo menos vários milhares" de vítimas (Poliakov, 1974, Vol. I, pg. 45).

${ }^{853}$ Mintz, 1984, pgs. 98 e 99.

${ }^{854}$ Mintz, 1984, pgs. 98 e 99 / Roskies, 1984, pg. 48.

${ }^{855}$ Mintz, 1984, pg. 89.

${ }^{856}$ Piyyut (פיוט), pl. piyyutim - "poema litúrgico". Composição hebraica lírica intencionada para embelezar uma prece obrigatória ou qualquer outra cerimônia religiosa. Alguns piyyutim foram incorporados na liturgia e tornaram-se indistinguíveis do restante das preces.
} 
Como vimos anteriormente ${ }^{857}$, a literatura de 1096 rompeu com o modelo tradicionalmente aceito, herdado tanto da Bíblia Hebraica quanto da literatura rabínica clássica, que explicava catástrofes nacionais como sendo punição divina por transgressões dos mandamentos. Como novidade trazida por estes piyyutim e crônicas medievais, não se menciona nenhum pecado cometido pelas comunidades judaicas do Reno que pudesse ter provocado o hurban.

Ao invés disto, os memorialistas de $1096^{858}$ explicaram o hurban resgatando uma explicação para o sofrimento que, até então, fora marginal no judaísmo - o conceito de "aflições por amor" (יסורים של אהבה). A idéia já estava presente no Pentateuco, no episódio do teste-de-fé de Abraão com o Sacrifício de Isaac (Gn 22), assim como no Livro de Jó e na literatura rabínica clássica. É a concepção de sofrimento como uma oportunidade outorgada por Deus a indivíduos merecedores e sem pecados, para demonstrarem uma retidão exemplar e, assim, serem dignos de recompensas, durante sua vida ou no mundo-vindouro. Antes dos eventos no Reno, este conceito fora aplicado apenas em casos individuais e anômalos, e não como explicação para todo um hurban.

Em paralelo, os memorialistas de 1096 também buscaram uma imagem que pudesse simbolizar para as gerações futuras os atos sem precedentes dos judeus do Reno - o assassinato de seus familiares, seguido de suicídio. O teste-de-fé de Abraão ${ }^{859}$ não se adaptava bem, pois o patriarca não teve que assassinar seu filho, ao contrário dos judeus do Reno. Outros personagens paradigmáticos do passado ${ }^{860}$, especialmente Daniel e Rabi Akiva, também foram examinados, mas nada se firmava como um precedente adequado para o surpreendente ato de martírio dos judeus ashkenazim. "Questione e procure: houve alguma vez tal oferenda sacrificial em massa desde o tempo de Adão?”, perguntou retoricamente um dos memorialistas ${ }^{861}$.

Finalmente, os poetas e cronistas medievais encontraram a imagem que buscavam no ritual de sacrifícios de animais no Templo de Jerusalém. Um dos

\footnotetext{
${ }^{857}$ Vide capítulo "Por Causa de Nossos Pecados".

${ }^{858}$ Mintz, 1987, pgs. 43 e 44 / Mintz, 1984, pgs. 91 e 92 / Marcus, 1982, pg. 47.

${ }^{859}$ Roskies, 1984, pgs. 42 e 43.

${ }^{860}$ Mintz, 1984, pgs. 90 e 91.

${ }^{861}$ Marcus, 1982, pg. 45.
} 
piyyutim de 1096 faz uma correlação direta entre os judeus do Reno e a ordem dos sacrificios no antigo santuário: as crianças ashkenazim assassinadas por seus pais correspondiam aos pequenos cordeiros oferecidos no Templo, enquanto a preparação e morte de esposas e filhos pelo chefe-de-família em antecipação à chegada dos cruzados correspondia ao preparo e à morte de animais pelo sacerdote ${ }^{862}$.

Ao conseguirem relacionar ${ }^{863}$ o comportamento dos judeus do Reno com um ato religioso supremo do passado, os memorialistas legitimizaram suas ações. As comunidades do Reno passaram a ser comparadas a Jerusalém e, sua destruição, ao hurban do Templo, embora os dois eventos estivessem separados por mais de mil anos.

O impacto dos piyyutim e crônicas do ano $1096{ }^{864}$ foi enorme para os oito séculos seguintes de judaísmo ashkenazi. Os atos dos judeus do Reno e a literatura que os retratou, especialmente os poemas litúrgicos, tornaram-se a norma judaica de resposta a um hurban. Não que o suicídio coletivo tenha se tornado um padrão de comportamento frente a perseguições, mas a imagem dos mártires de 1096 tornou-se soberana, um ideal pelo qual futuras condutas deveriam ser medidas.

Os eventos de 1096 também ${ }^{865}$ levaram a outras modificações no judaísmo. A experiência de violência extrema introduziu um inédito culto aos mortos na cultura ashkenazi e, de lá, espalhou-se para todo o judaísmo. Primeiro, as autoridades rabínicas que surgiram no imediato período pós-cruzadas instituíram o Kadish, uma prece de luto recitada até hoje. Depois, no século XV, instituiu-se o ritual fúnebre do Yorzeit, a comemoração do aniversário da morte de um familiar. Em seguida, foi instituído o Yizkor, prece fúnebre recitada por toda a congregação no Dia do Perdão e em outras datas destacadas do calendário judaico.

\footnotetext{
${ }^{862}$ Mintz, 1984, pgs. 93, 94, 96 e 97.

${ }^{863}$ Marcus, 1982, pgs. 43, 48 e 49.

${ }^{864}$ Mintz, 1984, pgs. 7, 89 e 98.

${ }^{865}$ Mintz, 1984, pgs. 100 e 101.
} 
D) A Expulsão da Espanha (1492)

Em 31 de março de 1492, os reis Ferdinando e Isabela assinaram ${ }^{866}$ um édito expulsando os judeus da Espanha. Assim, colocaram um ponto final em séculos de civilização judaica sefaradi. A maior e mais orgulhosa comunidade judaica do continente foi desraizada e, como consequência, o ocidente europeu ficou esvaziado de judeus. Os que não aceitaram a conversão imediata tiveram quatro meses para vender suas propriedades e deixar o reino. Cerca de 150 mil judeus seguiram para o exílio, enquanto 50 mil se converteram.

A experiência de deslocamento levou a um grande sofrimento e mais violência. Navios carregados de refugiados foram atacados por piratas e outros afundaram. Em Portugal, onde boa parte dos judeus espanhóis encontrou refúgio, foram escravizados e forçados a se batizar. Em 1506, explodiu uma perseguição em Lisboa que matou mais de mil judeus ${ }^{867}$.

Os pensadores judeus precisaram responder a mais este hurban, que vitimara justamente a parcela que permanecera fiel à religião, aquela que recusou os benefícios da conversão. Nestas reflexões, de um modo geral, a tradicional explicação "por causa de nossos pecados" foi retomada e amplamente utilizada. Outro tradicional conceito judaico, o de "sofrimento como sinal da chegada iminente da era messiânica", tambem está bastante presente nos escritos da época ${ }^{868}$.

Porém, deve-se notar também na literatura de 1492 a introdução de novos conceitos de explicação para um hurban. Um deles foi uma interpretação astrológica para a catástrofe. Um escrito rabínico do século XVI afirmou que calamidades acometeriam periodicamente o povo judeu como consequência de Saturno ser sua estrela-guia. Estar sob influência de Saturno, afirma o documento, significaria servidão, pobreza e degradação, assim como pendência para a reflexão, especulação e sabedoria ${ }^{869}$.

\footnotetext{
${ }^{866}$ Poliakov, 1974, Vol. II, pgs. 198 e 199 / Yerushalmi, 1982, pgs. 59 e 60.

${ }^{867}$ Poliakov, 1974, Vol. II, pgs. 201 e 202 / Margolis, 1967, pgs. 470 a 476.

${ }^{868}$ Rosenberg, 1983, pgs. 401, 402, 404 e 405 / Schweid, 1994, pgs. 312 e 313.

${ }^{869}$ Rosenberg, 1983, pgs. 405 e 406.
} 
Outra novidade em termos de resposta a um hurban é a explicação cabalista para os eventos de $1492{ }^{870}$. A mensagem reconfortante dos rabinos místicos foi de que a redenção deveria agora ser operada a nível pessoal, desvinculada do coletivo. Diziam que mesmo numa situação degradante de exílio, o judeu poderia vivenciar uma experiência espiritual pessoal, que representaria o preparo para a redenção universal que aconteceria no futuro.

Um outro tipo de resposta ao hurban de 1492 foi a relocação da criatividade religiosa sefaradi em outros países, onde as vítimas encontraram refúgio e voltaram a prosperar. Destaca-se o florescimento do judaísmo nos anos seguintes à Expusão na cidade de Safed, na Palestina, que tornou-se um importante centro irradiador de cultura judaica a partir de então ${ }^{871}$.

E) Massacres durante a revolta cossaca de Bogdan Chmielnicki (1648-49)

No crepúsculo da Idade Média, os judeus da Polônia ${ }^{872}$ viveram um período dourado, produzindo os principais financistas do país e os mais destacados rabinos do continente. Viviam confortavelmente, especialmente nos vastos territórios da atual Ucrânia, onde supervisionavam com mão-de-ferro os camponeses locais, representando a nobreza polonesa. Este equilíbrio, porém, era tênue: os servos ucranianos, de religião grega-ortodoxa, odiavam seus senhores católicos e, ainda mais, os administradores judeus, muito mais visíveis em seu cotidiano.

Em 1648, o chefe militar cossaco Bogdan Chmielnicki ${ }^{873}$ unificou os ucranianos descontentes e comandou a expulsão dos estrangeiros, em seguida invadindo a Polônia. Apesar das grandes perdas para a nobreza polonesa - o país deixou de ser uma potência européia como consequência da destruição -, o conflito vitimou de maneira particular as desprotegidas comunidades judaicas. Nenhuma delas ficou livre da violência, centenas desapareceram para sempre, resultando na morte de

\footnotetext{
${ }^{870}$ Rosenberg, 1983, pgs. 417 e 418 / Scholem, 1975, pgs. 15, 18 e 19.

${ }^{871}$ Schweid, 1994, pg. 314 / Scholem, 1975, pgs. 15 e 19.

${ }^{872}$ Poliakov, 1974, Vol. I, pgs. 256 a 258 e 261 / Mintz, 1984, pg. 103.

${ }^{873}$ Poliakov, 1974, Vol. I, pgs. 257 e 258.
} 
aproximadamente 100 mil judeus. Este é considerado ${ }^{874}$ o último hurban antes da era moderna.

O hurban de 1648-49, que foi seguido de outras violências anti-semitas nos 30 anos seguintes ${ }^{875}$, colocou um ponto final na era de ouro do judaísmo polonês. A comunidade como um todo se desestruturou e nunca mais se recuperaria. De financistas destacados, os judeus em sua maioria passaram a viver em extrema pobreza, até serem liquidados no Holocausto nazista.

Como consequência imediata do hurban de 1648-49, instituiu-se uma nova data no calendário judaico da Polônia, o jejum de 20 de Sivan, aniversário de um dos primeiros massacres comandados por Chmielnicki, uma data observada até o século XX ${ }^{876}$. Outra consequência ${ }^{877}$ foi o surgimento do maior movimento de falsomessianismo da história do exílio, liderado por Shabetai Zvi. Apresentando-se em público pela primeira vez justamente no ano 1648, Zvi capitaneou o desespero espiritual da época, prometeu a redenção final, mas acabou ludibriando e trazendo mais sofrimento a milhares de seguidores.

Um documento teológico central ${ }^{878}$ para o hurban de 1648-49 é a crônica

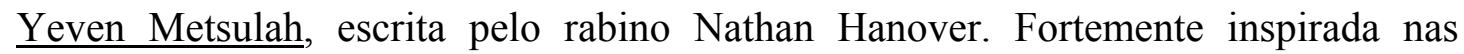
crônicas judaicas das Cruzadas, também aqui nenhum grande pecado é imputado às vítimas de Chmielnicki. Os judeus poloneses massacrados são vistos por Hanover como mártires, objetos de uma prova divina para testar a fé da comunidade. Apesar deste hurban ter sido muito mais destrutivo física e materialmente que a catástrofe promovida pelos cruzados, seus memorialistas contentaram-se em utilizar os parâmetros conceituais elaborados em 1096.

\footnotetext{
${ }^{874}$ Mintz, 1984, pg. 102.

${ }^{875}$ Ben-Sasson, 1974, pg. 730.

${ }^{876}$ Poliakov, 1974, Vol. I, pg. 260.

${ }^{877}$ Poliakov, 1974, Vol. I, pg. 262.

${ }^{878}$ Mintz, 1984, pgs. 103 a 105.
} 
Poderíamos inserir as reflexões de Soloveitchik, Berkovits e Greenberg nesta longa tradição judaica de Literatura de Hurban, ao invés de considerá-las “teologias"? Qual seria a consequência? 


\section{0 - CONCLUSÃO}

As reflexões de Soloveitchik, Berkovits e Greenberg sobre o Holocausto, quando consideradas separadamente, são elegantes e bem articuladas, com potencial para fornecer ao fiel respostas e consolo ${ }^{879}$. Mas o ponto principal destacado por esta tese é a dissonância observada ao compararmos estas reflexões entre si. Os três rabinos não concordaram plenamente sobre nenhum dos nove conceitos e temas que aplicaram para o caso do Holocausto. Se considerada como um bloco, a Ortodoxia Moderna dos EUA parece não ter fornecido ao fiel uma reflexão consistente.

Esta tese destacou três elementos para pensarmos as razões da existência de contradições entre os três pensadores: a aceitação de controvérsias na tradição rabínica; a ausência de tradição teológica no judaísmo; a importância da Literatura de Hurban.

Comecemos pelo primeiro elemento. Se nos basearmos nisto, poderíamos explicar a inconsistência das respostas da Ortodoxia Moderna dos EUA sobre a Shoá como algo a ser esperado, e até mesmo, saudado como positivo. O próprio Greenberg utiliza este elemento para explicar estas contradições (vide Apêndice).

Sem descartar totalmente esta explicação, esta tese prefere não utilizá-la como princípio para a compreensão da inconsistência entre os três pensadores. Esta recusa é baseada numa idéia tipicamente judaica, apresentada anteriormente ${ }^{880}$ e que chamamos de "regra-de-ouro" do rabinismo: tolera-se o debate no plano teórico (isto é, durante as discussões sobre a halakhah), mas exige-se total obediência no plano da prática (isto é, na aceitação por toda a comunidade da halakhah promulgada). O que isto tem a ver com as reflexões sobre o Holocausto?

A meu ver, neste ponto, os rabinos diferenciaram dois níveis de importância na vivência religiosa judaica. Num primeiro nível, mais básico, quando a halakhah

\footnotetext{
${ }^{879}$ Interessante notar a presença de uma idéia central do pensamento de Berkovits no best-seller When Bad Things Happen to Good People, do rabino norte-americano Harold Kushner. Quando este autor apresenta uma explicação para o Holocausto, baseia-se no conceito de livre-arbítrio como exposto por Berkovits (Kushner, 1983, pgs. 80 a 82).

${ }^{880}$ Vide mais acima "A Aceitação da Diferença de Opiniões no Judaísmo".
} 
ainda está em dicussão, aceita-se a diferença de opiniões e estimula-se o debate, como uma maneira de enriquecer o processo decisório. Mas num segundo nível, mais delicado, onde trata-se de unificar a comunidade sob a mesma lei religiosa, as dissonâncias não são mais toleradas e todos precisam estar em sintonia.

Penso que o desafio religioso trazido pelo Holocausto também está situado num nível mais elevado da vivência judaica. Assim como não se tolera discordâncias a respeito da lei, penso poder afirmar que não deveríamos aceitar respostas vãs sobre o Holocausto. O hurban do século XX foi por demais destruidor e desafiador das bases do judaísmo para, simplesmente, fazermos paz com a idéia de que "cada rabino pode ter sua opinião a respeito da Shoá”. O fiel, que levanta questões extremamente delicadas sobre o Holocausto, não pode se contentar com a idéia de que "controvérsias são parte da nossa tradição".

O segundo elemento destacado nesta tese como potencial explicador para a inconsistência da Ortodoxia Moderna em relação à Shoá é a fraca presença de tradição teológica no judaísmo. Aqui, as contradições observadas entre os três pensadores seriam explicadas como uma consequência natural do pouco desenvolvimento da teologia nesta religião. Afinal, deveríamos esperar obras harmônicas, unificadas e consistentes se estas fazem parte de um campo secundário e pouco exercitado?

Porém, ao se classificar as reflexões de Soloveitchik, Berkovits e Greenberg como "teologias", estas são imediatamente inseridas num campo marginal do judaísmo. Minimiza-se o status destas obras e suas possíveis contribuições. E, novamente, surge o dilema: o judaísmo pode se dar ao luxo de marginalizar os esforços de seus pensadores em fornecer aos fiéis uma explicação para um hurban? As reflexões sobre a Shoá podem ser tratadas como um assunto secundário dentro da existência judaica? 
O termo "Teologia do Holocausto" parece ter se firmado como designação para as reflexões judaicas sobre a Shoá ${ }^{881}$. Porém, deve-se notar que há pouca base para considerar as reflexões dos três pensadores examinados nesta tese como "teologia". Na realidade, eles realizaram reflexões judaicas típicas, a partir de conceitos religiosos clássicos e sempre se mantendo dentro da tradição, dialogando primordialmente com fontes como a Bíblia Hebraica, o Talmud e o pensamento judaico medieval. Quase não se percebe influência de elementos extra-judaicos, como Filosofia, Ciência da História ou Teologia do tipo cristã, em suas reflexões sobre o Holocausto. Deveríamos aplicar um termo marginal no judaísmo - teologia - para classificar pensamentos genuinamente judaicos?

Esta tese quer propor que as reflexões de Soloveitchik, Berkovits e Greenberg não sejam classificadas como "teologias", nem que as contradições que surgem ao compará-las sejam simplesmente tomadas como "saudáveis controvérsias". Como conclusão desta pesquisa, gostaríamos de propor que estas reflexões sejam inseridas num campo bem mais tradicional e extremamente importante do judaísmo - a Literatura de Hurban.

Como vimos anteriormente ${ }^{882}$, sob o título Literatura de Hurban agrupam-se reflexões feitas por pensadores judeus de épocas muito diferentes, incluindo profetas, historiadores bíblicos, rabinos e poetas medievais. Em comum, é ressaltado o fato de serem obras de importância vital para o judaísmo. Produzidas sob o impacto dos maiores hurbanot que se abateram sobre o povo judeu, representaram esforços para dar sentido a eventos que abalaram as estruturas da religião.

Produzidas ao longo de 2500 anos, as reflexões da Literatura de Hurban estão longe de ser um mero exercício intelectual ou um simples passatempo refinado de uma elite desvinculada da vida prática do judaísmo. Pelo contrário, esta literatura foi essencial para permitir a continuidade da religião judaica após o choque dos hurbanot.

\footnotetext{
${ }^{881}$ Cohn-Sherbook entitulou a coletânea de reflexões que editou como "Holocaust Theology - A Reader", em 2002. Steven Katz chamou "Jewish Theological Responses" o verbete que escreveu para a Encyclopedia of Religion sobre o Holocausto, em 1987.

${ }^{882}$ Vide mais acima “A importância da Literatura de Hurban”.
} 
Quando examinamos mais acima a Literatura de Hurban, vimos como foram importantes as reflexões dos profetas, que permitiram ao judaísmo superar a perda do Templo de Jerusalém e a destruição da dinastia de Davi, no ano 586 a.e.c. Da mesma maneira, se não fossem as novas idéias apresentadas pelos rabinos fariseus, após o hurban do ano 70, a religião provavelmente não teria sobrevivido ao longo exílio que se seguiu. Também, sem o esforço dos memorialistas das Cruzadas, teria sido difícil superar o trauma dos massacres do ano 1096.

Ao incluirmos as reflexões de Soloveitchik, Berkovits e Greenberg como parte da Literatura de Hurban, abrem-se novas possibilidades de entendimento destas obras, inclusive a existência de contradições entre elas. Vejamos isto com mais detalhes.

Quando analisamos anteriormente a Literatura de Hurban, notamos que algumas vezes pensadores vivendo no imediato pós-hurban reagiram de forma confusa, perplexa ou com um longo silêncio frente a uma catástrofe que lhes parecia assombrosa e inexplicável. Isto ocorreu com o autor bíblico do livro Lamentações, após o hurban do ano 586 a.e.c., assim como com os rabinos tanaim, após a destruição de Jerusalém, no ano 70.

Quando procuramos explicações para as incongruências observadas nas reflexões dos três pensadores examinados nesta tese, é preciso levar em consideração que trata-se de autores ainda vivendo muito próximos do hurban. Vimos anteriormente ${ }^{883}$ como nas duas décadas que se seguiram ao Holocausto, imperou um inquietante silêncio entre os pensadores judeus. Ora, Soloveitchik escreveu seu principal ensaio sobre a Shoá, Kol Dodi Dofek, em 1956, ou seja, durante este período crítico. E Berkovits publicou sua principal obra, Faith After the Holocaust, imediatamente após este período.

Adicionado a isto, se levarmos em consideração que os três rabinos examinados nesta tese foram atingidos pessoalmente pelo Holocausto, seja tornandose pessoalmente refugiados do nazismo, seja perdendo parentes próximos no massacre, a inescapável conclusão é de que trata-se de pensadores que viveram muito

${ }^{883}$ Vide mais acima "A Teologia do Holocausto - Uma Introdução". 
próximos ao hurban. Portanto, a pergunta que se coloca é se deveríamos esperar reflexões pausadas e livres de contradições nestas circunstâncias.

Outros aspectos das reflexões de Soloveitchik, Berkovits e Greenberg parecem fazer mais sentido se consideradas como parte da Literatura de Hurban. Por exemplo, a revolta contra Deus, observada em alguns momentos nas obras de Berkovits e Greenberg, podem ser inseridas numa longa tradição judaica de diálogo com a divindade. Assim como o autor bíblico de Lamentações dirigiu-se a Deus com um agudo senso de indignação ("o Senhor porta-se como um inimigo, devora Israel” ${ }^{884}$ ), o mesmo ocorreu com Berkovits (“o domínio de Deus sobre o mundo não é um domínio de justiça”) e Greenberg (“do ponto-de-vista moral, Deus precisa ter remorso pela Aliança").

Outro exemplo é a sugestão de Greenberg de se introduzir idéias e conceitos totalmente novos no judaísmo para enfrentar o desafio do Holocausto. Longe de ser uma mostra de radicalismo, esta sugestão insere-se perfeitamente na Literatura de Hurban. Vimos que os profetas introduziram o conceito "por causa de nosso pecados" para dar sentido à destruição do ano 586 a.e.c. Posteriormente, os rabinos talmúdicos, sob o impacto do hurban do ano 70, iniciaram o eclipse deste conceito, o que só foi completado pelos memorialistas das cruzadas, que propuseram em seu lugar a idéia de “aflições por amor". Situação semelhante ocorreu após o hurban do ano 1492, quando pensadores judeus propuseram conceitos novos baseados na cabala e astrologia.

Quando Greenberg aponta para a inadequação das preces judaicas tradicionais para dar conta de necessidades espirituais frente ao Holocausto, sugerindo a necessidade de se elaborar novas orações, isto também tem antecedentes na Literatura de Hurban. Vimos anteriormente como o hurban do ano 1096 teve como uma de suas consequências o estabelecimento da prece Kadish e outras.

Outros paralelos entre as reflexões judaicas sobre o Holocausto e a Literatura de Hurban poderão ser evidenciados quando se estudar com maior profundidade esta ligação. Nesta tese, devido às suas naturais limitações, pudemos fazer apenas uma 
exposição inicial destes paralelos, esperando que numa outra oportunidade, deste pesquisador ou de outros, isto possa ser aprofundado.

Agora, estamos prontos a responder às questões que nortearam toda esta pesquisa. Para a primeira delas - os pensadores do Holocausto proveram seus fiéis com respostas à altura da terrível catástrofe? - a resposta é positiva. Sim, Soloveitchik, Berkovits e Greenberg elaboraram reflexões elegantes sobre a Shoá. Ao mesmo tempo, devemos ter em mente que trata-se de autores localizados historicamente por demais próximos da grande destruição para exigirmos harmonia ou ausência de contradições. A Literatura de Hurban mostra que teremos que esperar anos, décadas e talvez séculos para que o judaísmo possa assimilar totalmente o impacto do Holocausto.

Para outra questão que norteou esta pesquisa - o florescimento do judaísmo após 1945 dependeu de alguma maneira das reflexões sobre o Holocausto ou foi um fenômeno independente? -, penso poder responder que o pensamento dos três rabinos examinados nesta tese, assim como os demais autores da chamada Teologia do Holocausto, deram sua contribuição. Muitos judeus leram estas reflexões e, ali, encontraram consolo e respostas. Porém, ao analisarmos como gerações passadas reagiram aos hurbanot de suas épocas, há um elemento adicional que deve ser levado em consideração.

Respostas intelectuais não foram a única maneira do judaísmo historicamente reagir a um hurban. Quando os romanos se preparavam para destruir Jerusalém e seu templo, no ano 70, os fariseus solicitaram permissão dos conquistadores para que um novo centro religioso pudesse ser construído na cidade de Yavne. Desta maneira, após o hurban, o judaísmo pode ter um novo recomeço. De maneira semelhante, após a Expulsão da Espanha em 1492, a criatividade judaica encontrou um novo ambiente em Safed, na Galiléia, para continuar seu desenvolvimento.

Depois do hurban do século XX, enquanto pensadores judeus elaboravam suas reflexões sobre a Shoá, outros ativistas cuidavam para que novas instituições fossem fundadas ao redor do globo. Escolas, sinagogas, clubes e outras associações 
forneceram a base material para o reerguimento do judaísmo nos principais países do Ocidente.

A depressão trazida pelo Holocausto também recebeu um contrabalanço com o novo clima de tolerância ao judaísmo que passou a vigorar no mundo ocidental. $O$ anti-semitismo declinou e inaugurou-se uma nova era de liberdade que o judaísmo aproveitou para reflorescer. Em especial nos EUA, ocorreu uma tremenda explosão positiva de cultura e produção religiosa judaica.

Mas talvez nada simbolize tão bem a resposta do judaísmo ao Holocausto quanto a fundação do Estado de Israel, três anos após o final da Segunda Guerra Mundial. Mesmo com todas suas limitações, o país projetou uma nova esperança para o futuro do judaísmo. Nenhuma reflexão intelectual parece ter alcançado o nível de consolo fornecido pelo novo espaço de liberdade aberto pelo Estado judeu.

Isto não significa que devemos deixar de esperar e mesmo exigir respostas intelectuais à altura da Shoá. Estas reflexões terão de vir para dar conta das grandes questões que permanecem em aberto. As discordâncias entre os pensadores deverão diminuir, até que o judaísmo forneça uma resposta mais unificada, como aconteceu em hurbanot passados. Mas a visão deste futuro está além da nossa capacidade, sobreviventes do Holocausto que todos somos. 


\section{APÊNDICE: ENTREVISTA COM IRVING GREENBERG}

(realizada em Maio/2005)

OBS: As informações complementares que aparecem entre parênteses () são de Irving Greenberg e as informações entre colchetes [] são de Ariel Finguerman.

FINGUERMAN - Rabino Irving Greenberg, pediria que o sr. comentasse a reflexão de Eliezer Berkovits sobre o Holocausto. Qual foi sua maior contribuição? O sr. discorda de algumas de suas posições?

GREENBERG: Não tenho os livros de Berkovits neste momento na minha frente e o que direi virá da minha memória, o que pode não ser a coisa mais justa a se fazer. Mas de acordo com meu julgamento, os seus mais valiosos pensamentos sobre o Holocausto incluem o seguinte:

a) levando-se em consideração o Holocausto, não são mais viáveis a teologia do "Por Causa de Nossos Pecados", nem a idéia de o que acontece na história é resultado de midah keneged midah ["medida contra medida", idéia tradicional judaica de que Deus castiga ou abençoa um indivíduo ou nação exatamente de acordo com suas ações]. A teoria da correspondência foi decididamente afastada pelos eventos da Shoá. Continuo me supreendendo com pessoas que mantêm a pregação de tal teologia no mundo em que vivemos. A recusa de Berkovits e sua passional crítica desta visão foram uma grande contribuição.

b) Sua coleta e explicação de halakhot que se originaram na Shoá e na vida religiosa dos judeus sob o Holocausto é uma importante contribuição. Seu livro With God in Hell confirma a profundidade e o poder da religião, mesmo sob a pior das circunstâncias. Também aprofunda nosso entendimento e respeito pela fé do judaísmo e dos judeus.

c) Outra importante contribuição de Berkovits é o reconhecimento de que eventos desta magnitude devem ser levados a sério do ponto-de-vista religioso e não se pode continuar vivendo como se nada tivesse acontecido.

d) Ele também insistiu na idéia de que os judeus vivem uma história espiritual e não podem ser derrotados ou destruídos por reveses políticos ou eventos negativos da História. Concordo com algumas das conclusões que ele extraiu deste insight, apesar da idéia em si ser suspeita. Minha conclusão pessoal é que a existência espiritual dos 
judeus e sua grandeza refletem dois mil anos de vida no exílio. Isto foi uma grande contribuição à dignidade judaica, ou seja, manter a fé num mundo hostil. No entanto, penso que o Holocausto rompeu esta síntese. Este evento foi um chamado para os judeus retornarem ao mundo da política, à arte do Estado e ao poder, a fim de serem absorvidos novamente no processo da História. Esta é a única maneira para os judeus sobreviverem (na realidade, acredito que eles farão mais do que sobreviver, eles se tornarão modelos e uma luz para as nações, se continuarem responsáveis e atuarem da maneira certa). Consequentemente, eu discordo das tendências espiritualizantes de Berkovits. Sua investigação sobre a grandeza do judaísmo face à falta de poder não deveria ser generalizada para cobrir toda a história judaica.

e) Sua crítica ao cristianismo face ao Holocausto é poderosa e merecida. Tendo dito isto, acho que Berkovits equivocou-se ao concluir que, consequentemente, não pode haver diálogo e o cristianismo deve ser visto como tendo perdido toda sua postura moral e seu direito de existir como religião. Na minha visão, os cristãos - ou pelo menos parte majoritária da Igreja cristã - fizeram uma penitência genuína após o Holocausto e à luz deste evento. Acredito que nós, judeus, também precisamos exercer auto-crítica à luz desta tragédia. Precisamos ter menos hostilidade, repúdio e estereótipos negativos a respeito de outras religiões e sermos mais abertos para aprender deles e com eles. Isto é essencial para desenvolver um tipo de responsabilidade humana que penso ser necessária para se construir um mundo melhor. Portanto, compartilho a crítica de Berkovits, porém faço um movimento em direção oposta, ao dialogo, à renovação da amizade, à parceria e ao aprendizado de um com o outro.

FINGUERMAN - Comente por favor a reflexão de Joseph Soloveitchik sobre o Holocausto. Qual foi sua maior contribuição? O sr. discorda de algumas de suas posições?

GREENBERG - O rabino Soloveitchik não escreveu muito sobre a Shoá. No entanto, este evento teve um profundo impacto sobre ele. Sua maior contribuição foi a ênfase no Estado de Israel como a resposta do povo judeu e de Ha-Shem [Deus] ao vazio absoluto criado pelo Holocausto. Em seu ensaio Kol Dodi Dofek, ele fala do Estado de Israel como sendo uma "batida na porta". Se você analisar o [livro bíblico] Cântico dos Cânticos, o som da batida é uma pista. Da mesma maneira, o Estado de Israel é 
uma pista de que Ha-Shem está presente e restaura nossa fé. A recriação de Israel nos dá uma garantia para permanecermos fiéis à nossa missão, ao nosso Deus, à nossa Torá. Todos os detalhes das implicações da "batida", explicadas em Kol Dodi Dofek como um reflexo da reciprocidade entre o Holocausto e Israel, eu aceito e me baseio nelas.

De modo geral, sinto que a maior parte das minhas posições podem ser consideradas como extensões do pensamento de Soloveitchik. Apesar dele não necessariamente concordar com estas extensões, estão em seu espírito. Logo, eu não discordo de suas posições a respeito da Shoá. No entanto, eu as avanço consideravelmente mais longe do que ele gostaria.

[Por exemplo] na introdução de Kol Dodi Dofek, Soloveitchik fala da Shoá como tendo sido uma noite de hester panim muhlat. De forma livre, esta expressão é traduzida como "absoluto ocultamento da face divina", ou seja, uma situação além do já-normal ocultamento de Deus. Já eu prefiro traduzi-la como "ocultamento da face divina multiplicado". É uma sugestão de que, à luz da Shoá, há momentos em que Deus não está presente [trecho sublinhado por Greenberg]. É um momento de ateísmo.

FINGUERMAN - O sr. identifica uma posição comum entre pensadores ortodoxos modernos como Irving Greenberg, Eliezer Berkovits e Joseph Soloveitchik no que diz respeito ao Holocausto?

GREENBERG - Os pontos de comunicação entre nós refletem nosso status de ortodoxos modernos. São eles:

(a) A Shoá desafia a fé herdada e o longo relacionamento entre Deus e o povo judeu. A vida religiosa não pode continuar como antes. Isto apesar de que, nós três, claramente não concordarmos quanto à extensão das mudanças que devam acontecer. (b) Após os questionamentos, as dúvidas e os conflitos, há uma reafirmação do relacionamento com Deus.

(c) O Estado de Israel é visto como uma resposta à Shoá. A destruição confirma o Estado de Israel e seu extraordinário significado religioso, bem como sua centralidade sociológica para o povo judeu. 
FINGUERMAN - Comparando sua reflexão especialmente com a de Berkovits, notase algumas dissimilaridades: Berkovits não entende o Holocausto como um evento único na história judaica, portanto ele utiliza em sua reflexão conceitos tradicionais do judaísmo para interpretá-lo. Já o sr. considera o Holocausto como um evento único e propõe novos conceitos para entendê-lo, como por exemplo, a idéia de "aliança voluntária".

Particularmente quanto à Aliança, Berkovits e o sr. apresentam posições bastante diferentes. Para ele, o pacto com Deus continua o mesmo após a Shoá e os judeus permanecem o mesmo povo escolhido do passado. Já para o sr., à luz do Holocausto, os judeus entraram numa nova fase da Aliança, de comprometimento voluntário.

Minhas questões são: Como é possível que duas visões quase contraditórias coexistam numa mesma corrente judaica, a Ortodoxia Moderna? O que isto nos ensina a respeito da teologia judaica? Mostra sua fraqueza ou força?

GREENBERG - Não concordo com sua afirmação de que eu considerei o Holocausto como um evento único. Na minha visão, a Shoá é, ao mesmo tempo [grifo de Greenberg], único e não-único. O Holocausto é único porque a quantidade e a extensão do ataque o fazem único. Em primeiro lugar, o povo judeu foi quase todo destruído. Em segundo lugar, seres humanos, ou seja, os nazistas, quase se tornaram Deus e, portanto, a idolatria foi muito mais ameaçadora. A Shoá é única na medida em que a totalidade da agressão foi sem precedentes.

Mas o Holocausto também levou a um extraordinário e novo estágio da Aliança e isto não é totalmente único, pois sempre esteve implícito na [idéia de] Pacto. Meu argumento é que, da mesma maneira que o hurban do Segundo Templo conduziu a um novo estágio da Aliança, também o novo hurban conduz a um novo estágio. Os judeus alcançaram um novo nível de desempenho na Aliança, que é expresso na aceitação voluntária do Pacto. Mas os três estágios de maturação [da Aliança] sempre estiveram implícitos no próprio conceito.

Você me pergunta como é possível a coexistência na Ortodoxia Moderna de “duas visões quase contraditórias". Em primeiro lugar, acho que não são 
contraditórias, mas sim que se situam num mesmo continuum ${ }^{885}$. Às vezes, quando olhamos de forma estreita para a nossa própria verdade, parece que esta abrange todo o continuum. Mas se dermos um passo atrás e observarmos todo o continuum, idéias que antes pareciam muito diferentes, na verdade podem se situar no mesmo continuum. Portanto, certas idéias de Berkovits podem se diferenciar das minhas, mas acredito que estamos situados num mesmo continuum.

Mas eu admito livremente que somos diferentes. Isto levanta sua questão de como podem coexistir diferentes visões numa mesma corrente do judaísmo. Isto mostraria fraqueza ou força da teologia judaica? Eu diria que as diferenças são claramente uma força. Este é justamente o ponto na idéia talmúdica de elu v'elu divray elokim chayim ["tanto isto como aquilo são palavras do Deus vivo", ou seja, dois pontos-de-vista diferentes são considerados ambos válidos]. Eu apontaria para a halakhah e para a tradição rabínica em geral como fortes enfatizadoras do papel construtivo do debate e da importância de se registrar diferentes opiniões. Mesmo que um diga "é permitido" e outro "é proibido" ou um diga "é puro" e outro "é impuro", o Talmud enfatiza que ambos os julgamentos são partes da mesma verdade. Este método, ao incorporar uma crítica mútua e argumentos contrários, salienta e clarifica a verdade de uma maneira melhor que enunciados monolíticos, simplistas e autoritários.

De modo geral, o corpo literário da Torá é um modelo vivo de como idéias contraditórias e conflituosas podem ser mantidas juntas em tensão, para que se tornem dialéticas e assim estimulem e energizem umas às outras. Desta maneira, tornam-se parte da afirmação de um mesmo continuum. [Por exemplo,] os rabinos afirmaram que o Livro de Juízes era normativo e o canonizaram. Este livro proclama que, quando os judeus ouvem Deus, vivem em liberdade, mas quando não ouvem, são oprimidos. Os mesmos rabinos canonizaram o Livro de Jó, que claramente conclui rejeitando a crença de que neste mundo as pessoas têm o destino que merecem baseado em suas ações. Da mesma maneira, os rabinos incorporaram muitas afirmações de absoluta fé e confiança em Deus, do caráter significativo da vida e tradição, em livros como o Pentateuco e Provérbios. Mas eles também incluíram no

\footnotetext{
${ }^{885}$ continuum $=$ um todo coerente caracterizado como uma coleção, sequência ou progressão de valores e elementos que variam de acordo com pequenos graus (Encyclopedia Britannica Online).
} 
cânone um livro como o Eclesiastes, que beira o cinismo e o niilismo e que descreve este mundo como um lugar de muita injustiça e de um ciclo-de-vida sem sentido. Acredito que todas estas verdades conflituosas estão corretas. Somos mais ricos espiritualmente porque os rabinos as incorporaram, ao invés de rejeitá-las ou suprimilas.

Também podemos aprender a partir das diferenças entre Berkovits e eu que a teologia judaica reflete a biografia da pessoa e a singularidade de cada indivíduo. A singularidade é uma das dignidades fundamentais da imagem de Deus (veja o Tratado Sanhedrin pg 37a do Talmud da Babilônia). A capacidade de singularidade sugere que indivíduos vêem aspectos diferentes do divino. Respeitar a singularidade significa levar em consideração os diferentes elementos que estão envolvidos num julgamento sobre teologia e tradição. Novamente, aqui, acredito ser possível discordar e, mesmo assim, compartilhar compromissos fundamentais. A discordância enriquece o pensamento de ambos os lados.

FINGUERMAN - Gostaria que o sr. comentasse a importância para o judaísmo das reflexões teológicas a respeito do Holocausto. Considere o seguinte:

(a) como o sr. mesmo afirma, a maior parte do povo judeu decidiu voluntariamente seguir o judaísmo após a Shoá. Mas isto foi consequência do sucesso dos pensadores judeus em apresentar uma visão coerente sobre o Holocausto? Afinal de contas, esta massa de pessoas lê reflexões teológicas?

(b) os haredim [ultra-ortodoxos] quase não escreveram sobre o Holocausto e, mesmo assim, eles formam um dos segmentos mais dinâmicos do judaísmo contemporâneo. Isto mostra que a reflexão teológica sobre o Holocausto é desnecessária?

GREENBERG - Em geral, a maioria das pessoas não lê teologia. No entanto, acredito que a maior parte dos indivíduos vive teologia. As pessoas fazem julgamentos básicos sobre o mundo e seu significado, e isto se reflete em seus comportamentos básicos. Por exemplo, no Gueto de Varsóvia, quando a falta de esperança ficou clara, houve uma queda severa na taxa de nascimentos. Mas, após a Segunda Guerra Mundial, nos campos de refugiados, ocorreu uma das maiores taxas de nascimento do mundo. Aqui, novamente, o comportamento humano é uma afirmação teológica: conceber crianças como uma afirmação da crença no valor da vida, num Deus que se preocupa e que 
sustenta a vida. Ou seja, ao observarmos o comportamento humano, vemos que, frequentemente, as pessoas agem através de um tipo de totalização intuitivo de toda a evidência de suas vidas, de seus pensamentos e de teologia. Mesmo que suas conclusões não sejam articuladas de uma maneira intelectual ou filosófica.

Meu pai costumava citar uma passagem do Talmud onde se diz "deixe com o povo judeu, pois se não são profetas, são filhos dos profetas". O ponto central aqui é que o que parece ser apenas comportamento natural de gente comum, na realidade origina-se de um entendimento intuitivo das questões teológicas mais profundas proclamadas pelos profetas - mesmo que estas pessoas nunca tenham lido os profetas. O povo judeu são filhos dos profetas, o que significa que continuam vivendo a partir da mais profunda percepção moral e espiritual e de confiança no divino. Já defini minha teologia como sendo um observar o que o povo judeu faz e depois descrever de forma teológica e filosófica.

Em uma de minhas reflexões sobre a Shoá, argumentei que fé é, em última análise, um compromisso elementar com a vida. Desde então tenho refletido mais sobre esta idéia. Acredito que a principal mensagem do judaísmo seja o triunfo da vida e a obrigação do indivíduo de fazer uma escolha pela vida. Através disso, cada um tem seu papel na vitória da vida sobre a morte. Isto é expresso através de comportamentos humanos elementares como amar alguém, casar-se, ter filhos e continuar vivendo como judeus.

De modo geral, o povo judeu tem sido um teólogo mais profundo que seus teólogos e rabinos. Fico desapontado com a liderança religiosa, que está tão entretida em seu próprio comportamento legalista e sua rotina teológica, que perde de vista eventos desafiadores como o renascimento do Estado de Israel e a Shoá. No entanto, o povo não perdeu de vista a natureza transformadora deste período e mudou de comportamento. Trocou a neutralidade pré-Segunda Guerra Mundial em relação ao sionismo para se tornar pró-sionista. Também a filantropia tornou a vida judaica novamente preciosa, através do crescimento de instituições comunitárias e da coleta de recursos. Teologicamente, isto equivale à restauração do tzelem elokim [imagem divina]. A maioria dos judeus vive bem sua teologia. $\mathrm{O}$ verdadeiro papel de um rabino 
ou teólogo é interpetrar e trazer à consciência o que as pessoas fazem de forma inconsciente. Aqui vejo muito do fracasso da liderança teológica no século passado.

Você afirma que "os ultra-ortodoxos quase não desenvolveram teologia sobre o Holocausto". Eu discordo. A interpretação predominante entre eles é que fomos castigados "por causa de nossos pecados". Acredito que, à medida que o tempo passa e a Shoá entra cada vez mais na consciência das pessoas, os haredim [ultra-ortodoxos] estarão cada vez mais impossibilitados de deixar de lado o desafio religioso trazido pelo Holocausto. Consequentemente, vemos agora um novo nível de resposta haredi, que enfatiza o Kidush Ha-Shem [martírio] e o fato de pessoas terem mantido a fé durante a Shoá. Considero esta abordagem muito apologética, pois ignora como a fé e a observância foram profundamente feridas pela Shoá. Mais importante, esta abordagem de Kidush Ha-Shem não trata do fato de que após a Shoá, todo discurso teológico de middah keneged middah ["medida contra medida", explicado mais acima] e de intervenção milagrosa simplista de Deus não é persuasiva. A contínua afirmação dos haredim de que existe recompensa e punição de acordo com o comportamento humano é simplesmente não-confiável diante do que aconteceu na Shoá (sem falar do que ocorre no mundo em geral). Recentemente, haredim mais aventureiros começam a se tornar mais abertos a um encontro litúrgico com a Shoá. Veremos aonde isto os levará.

Note, ainda, que os haredim reagiram de forma decidida à Shoá. Este dinamismo reflete o fato de que a Shoá pareceu a eles ter refutado a autoridade da modernidade. É difícil neste momento recapitular isto, mas na década de 30, muitos achavam que a modernidade iria vencer e que o judaísmo era um caso terminal. $\mathrm{Na}$ época, os haredim afirmavam que se a modernidade é absoluta e dominante, é preciso resistir e não se ligar a ela, do contrário, seriam engolidos. Após a Shoá, os haredim sentiram que a modernidade fora "refutada" [aspas de Greenberg] pelo comportamento maléfico dos nazistas. Isto permitiu a eles rejeitar a modernidade, retomar o dinamismo e reconstruir a vida comunitária. Além do mais, o apoio aos haredim vindo do restante da comunidade - desde a doação de recursos financeiros extraordinários até o apoio orçamentário do governo israelense - também reflete a maneira com que a Shoá quebrou a autoridade da modernidade entre muitos ortodoxos modernos e judeus seculares. Tudo isto contribuiu para a disposição de 
tolerar o comportamento haredi e de apoiar financeiramente sua tremenda expansão. Sem querer tirar o mérito da contribuição dos próprios haredim, através de sua devoção, trabalho duro e sinceridade, acredito que a Shoá forneceu muito do dinamismo por detrás de seu crescimento.

Gostaria de fazer um último comentário. Eu não acredito que a continuidade do judaísmo seja guiada unicamente pelo Holocausto. A visão fundamental do judaísmo é a vitória da vida sobre a morte. Deus é o Deus da vida. Todos os comentários da Torá podem ser resumidos na escolha pela vida - pelo menos esta é minha visão. A profecia, em parte, é a promessa de redenção, de que o mundo será perfeito e de que a vida vencerá a morte; a promessa de que, no final, o status quo será superado pela comunidade da aliança de Deus e a humanidade será conduzida por sua vanguarda, os filhos de Israel. O Holocausto representa o mais maléfico contratestemunho a tudo isto, um golpe contrário de idolatria. $\mathrm{O}$ sucesso nazista foi um desafio destruidor para todos os sonhos judaicos e todas as promessas da Torá. A Shoá representa o poder e a conquista do puro mal. Esta verdade não deve ser de nenhuma maneira suavizada pelo fato de que, a partir da resposta judaica à Shoá, ocorreu um renascimento e transformação do povo judeu. Quando a história do judaísmo for escrita, este período será reconhecido como a maior crise espiritual da história judaica, pois durante a Shoá, a morte venceu, a qualidade de vida sofreu e o mal triunfou na História.

No entanto, o mal não alcançou seus objetivos finais. O povo judeu renasceu após a Shoah e a Torá se reafirmou. Estamos vivendo a maior erupção de vida da história judaica. Isto não acontece apenas no plano físico, mas também no espiritual. Na Shoá, quase $80 \%$ dos rabinos e eruditos do Talmud foram assassinados. No entanto, hoje há mais pessoas estudando o Talmud em tempo integral do que nunca antes na história judaica e mais livros judaicos são impressos, vendidos e lidos. Tudo isto faz parte da incrível explosão de vida renovada. Há uma incrível afirmação da vitalidade do povo judeu e da tradição que o alimenta. 


\section{BIBLIOGRAFIA}

\section{FONTES PRIMÁRIAS}

BERKOVITS, Eliezer - “Authentic Judaism and Halakhah” in Judaism 19, 1970

BERKOVITS, Eliezer - "Authenticity of Being" in Judaism Transcends Catastrophe - God, Torah and Israel Beyond the Holocaust, editado por Jacob Neusner, Vol. I, Mercer University Press, Georgia, 1996

BERKOVITS, Eliezer - "The Biblical Meaning of Justice” in Judaism 18, 1969

BERKOVITS, Eliezer - "The Challenge to the Jewish Community - Religion, Life and the State of Israel" in Remembering for the Future, Pergamon Press, Oxford, 1988

BERKOVITS, Eliezer - "The Concrete Situation and Halakah" in Judaism Transcends Catastrophe - God, Torah and Israel Beyond the Holocaust, editado por Jacob Neusner, Vols. III, Mercer University Press, Georgia, 1996

BERKOVITS, Eliezer - "Confrontation - The Ultimate Issue" in Judaism Transcends Catastrophe - God, Torah and Israel Beyond the Holocaust, editado por Jacob Neusner, Vol. I, Mercer University Press, Georgia, 1996

BERKOVITS, Eliezer - “A Contemporary Rabbinical School for Orthodox Jewry” in Tradition, Vol.12, No. 2, 1971

BERKOVITS, Eliezer - Crisis and Faith, Sanhedrin Press, New York, 1976

BERKOVITS, Eliezer - "Death of a God" in Judaism 20, 1971

BERKOVITS, Eliezer - "The Encounter with God" in Judaism Transcends Catastrophe - God, Torah and Israel Beyond the Holocaust, editado por Jacob Neusner, Vols. II, Mercer University Press, Georgia, 1996

BERKOVITS, Eliezer - "Exile and Redemption" in Judaism Transcends Catastrophe - God, Torah and Israel Beyond the Holocaust, editado por Jacob Neusner, Vols. IV, Mercer University Press, Georgia, 1996

BERKOVITS, Eliezer - Faith After the Holocaust, Ktav Publishing House, New York, 1973

BERKOVITS, Eliezer - "Final Solution - Universal?" in Confronting Omnicide Jewish Reflections on Weapons of Mass Destruction, editado por Daniel Landes, Jason Aronson Inc., London 1991 
BERKOVITS, Eliezer - God, Man and History - A Jewish Interpretation, Jonathan David Publishers, New York, 1979

BERKOVITS, Eliezer - "He Called Them 'God's Cossacks"” in Sh'ma 10/183, December 14, 1979

BERKOVITS, Eliezer - "The Holy Nation" in Judaism Transcends Catastrophe God, Torah and Israel beyond the Holocaust, editado por Jacob Neusner, Vol. IV, Mercer University Press, Georgia, 1996

BERKOVITS, Eliezer - "Interfaith at Fifty" in Judaism, Vol. 27, No. 3, 1978

BERKOVITS, Eliezer - "The Jewish Claim to the Jewish Land” in Sh'ma 8/157, September 15, 1978

BERKOVITS, Eliezer - Judaism: Fossil or Ferment? , Philosophical Library, New York, 1956

BERKOVITS, Eliezer - "Judaism in the Post-Christian Era" in Judaism, Vol. 15, Numbers 1,2,3,4, The American Jewish Congress, New York, 1966

BERKOVITS, Eliezer - Major Themes in Modern Philosophies of Judaism, Ktav Publishing House, New York, 1974

BERKOVITS, Eliezer - Man and God - Studies in Biblical Theology, Wayne State University Press, Detroit, 1969

BERKOVITS, Eliezer - "The Miracle - Problem and Rationale" in Gesher, 7, 1979

BERKOVITS, Eliezer - "Not Chaos But Creation... Hence Meaning” in Sh'ma, 5/96, September 5, 1975

BERKOVITS, Eliezer - "Peace Now: A Response to my Critics” in Sh'ma, 10/189, March 7, 1980

BERKOVITS, Eliezer - "Rewriting the History of the Holocaust" in Sh'ma, 10/198, October 3, 1980

BERKOVITS, Eliezer - Towards Historic Judaism, The East and West Library, Oxford, 1943

BERKOVITS, Eliezer - With God in Hell - Judaism in the Ghettos and Deathcamps, Sanhedrin Press, New York, 1979

GREENBERG, Irving - "Cloud of Smoke, Pillar of Fire: Judaism, Christianity and Modernity after the Holocaust" in Auschwitz: Beginning of a New Era? Reflections on the Holocaust, editado por Eva Fleischner, Ktav Publishing House, New York, 1977 
GREENBERG, Irving - "The Dialectics of Power: Reflections in the Light of the Holocaust" in Confronting Omnicide - Jewish Reflections on Weapons of Mass Destruction, editado por Daniel Landes, Jason Aronson, New Jersey, 1991

GREENBERG, Irving - "The Ethics of Jewish Power" in Beyond Occupation American Jewish, Christian, and Palestinian Voices for Peace, editado por Rosemary R. Ruether e Marc H. Ellis, Beacon Press, Boston, 1990

GREENBERG, Irving - "Jewish Values and the Changing American Ethic" in Tradition, Vol. 10, No.1, Summer 1968

GREENBERG, Irving - The Jewish Way - Living the Holidays, Summit Books, New York, 1988

GREENBERG, Irving - "Judaism and Christianity: Covenants of Redemption" in Christianity in Jewish Terms, Westview Press, Oxford, 2000

GREENBERG, Irving - "Judaism and History: Historical Events and Religious Change" in Ancient Roots and Modern Meanings: A Contemporary Reader in Jewish Identity, editado por Jerry V. Diller, Bloch Publishing Company, New York, 1978

GREENBERG, Irving - "Judaism, Christianity, and Partnership After the Twentieth Century" in Christianity in Jewish Terms, Westview Press, Oxford, 2000

GREENBERG, Irving - Living in the Image of God - Jewish Teachings to Perfect the World (Conversations with Rabbi Irving Greenberg), editado por Shalom Freedman, Jason Aronson Inc, New Jersey, 1998

GREENBERG, Irving - "Orthodox Judaism and the Holocaust" in Gesher, Vol. 7, 1979

GREENBERG, Irving - "Religious Values After the Holocaust: A Jewish View" in Jews and Christians After the Holocaust, editado por Abraham J. Peck, Fortress Press, Philadelphia, 1982

GREENBERG, Irving - "The Teaching of the Holocaust" in Creators and Disturbers - Reminiscences by Jewish Intellectuals of New York, Columbia University Press, New York, 1982

GREENBERG, Irving - "The Third Great Cycle in Jewish History" in Perspectives, National Jewish Resource Center, New York, 1981

GREENBERG, Irving - "Toward Jewish Religious Unity" in The Ghetto and Beyond - Essays on Jewish Life in America, editado por Peter I. Rose, Random House, New York, 1969 
GREENBERG, Irving - "Voluntary Covenant" in Contemporary Jewish Religious Responses to the Shoah, editado por Steven Jacobs, University Press of America, Lanham, 1993

SOLOVEITCHIK, Joseph - Halakhic Man, The Jewish Publication Society of America, Philadelphia, 1983.

SOLOVEITCHIK, Joseph - The Halakhic Mind - An Essay on Jewish Tradition and Modern Thought, Seth Press, New York, 1986

SOLOVEITCHIK, Joseph - The Lonely Man of Faith, Jason Aronson, London, 1965.

\section{$\underline{\text { EM HEBRAICO }}$}

BERKOVITS, Eliezer - “Tov Ve-Ra, Muhlat O Yahasi - Rav Siah”, Petahim, 49-50, 1980

$$
\text { ברקוביץ, אליעזר - "טוב ורע, מוחלט או יחסי - רב-שיח", פתתים, 49-50, } 1980
$$

BERKOVITS, Eliezer - Mashber HaYahadut Be-Medinat HaYehudim, Hozaat Reuven Mass, Jerusalem, 1987

$$
\text { ברקוביץ, אליעזר - משבר היהדות במדינת היהודים, הוצאת ראובן מס, ירושלים, } 1987
$$

BERKOVITS, Eliezer - "Nokheah Morashtenu HaYehudit - Teguvah" in Shdamot, 72

$$
\text { ברקוביץ, אליעזר - "נוכח מורשתנו היהודית- תגובה", שדמות, ע"ב, תש"מ }
$$

BERKOVITS, Eliezer - Torat Hahigaion Ba-Halakhah, Mosad Harav Kuk, Jerusalem, 1986

$$
\text { ברקוביץ, אליעזר - תורת ההגיון בהלכה, מוסד הרב קוק, ירושלים, } 1986
$$

BERKOVITS, Eliezer - "Hevron - Herpah U-Simpatom" in Hazofeh, pg. 5, 22.11.1985

$$
\text { ברקוביץ, אליעזר - "חברון - חרפה וסימפטום", הצופה, עמוד 5, 22.11.1985 }
$$

BERKOVITS, Eliezer - "Smikhut Datit Be-Medinah Demokratit - Keizad” in Sinai: Yrhon Le-Torah U-Le-Madaei HaYahadut, 99:86 92

ברקוביץ, אליעזר - "סמכות דתית במדינה דמוקרטית - כיצד", סיני: ירחון לתורה ולמדעי היהדות צ"ט: פ"ו צ"ב, תשמ"ו 
SOLOVEITCHIK, Yosef - Divrei Hashkafah, Hamahlakah Le-Hinukh U-Le-Tarbut Toraniim Ba-Golah, Jerusalem, 1992 סולובייציק, יוסף דוב - דברי השקפה, המחלקה לחינוך ולתרבות תורניים בגולה, ירושלים, 1992

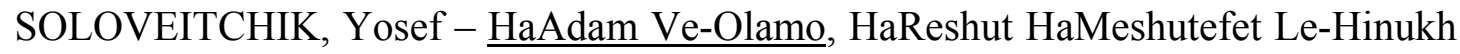
Yehudi - HaMahlakah Le-Hinukh U-Le-Tarbut Toraniim Ba-Golah, Jerusalem סולובייציק, יוסף דוב - האדם ועולמו, הרשות המשותפת לחינוך יהודי - המחלקה לחינוך ולתרבות תורניים בגולה, ירושלים, תשנ"ח

SOLOVEITCHIK, Yosef - Hamesh Drashot, Makhon Tel Orat, Jerusalem סולובייציק, יוסף דוב - חמש דרשות, מכון טל אורת, ירושלים, תשל"ד

SOLOVEITCHIK, Yosef - Kol Dodi Dofek, Misrad HaHinukh Ve-HaTarbut, Jerusalem, 1976 סולובייציק, יוסף דוב - קול דודי דופק, משרד החינוך והתרבות, ירושלים, 1976

SOLOVEITCHIK, Yosef - Min HaSeara - Masot Al Avelut, Ysurim Ve-Hamazav HaEnoshi, editado por David Shatz, Yoel Wolwalsky e Reuven Ziegler, Hozaat Amutat Torat HaRav, Jerusalem

סולובייציק, יוסף דוב - מן הסערה - מסות על אבלות, ייסורים והמצב האנושי, ערכו: דוד שץ, יואל וולוולסקי וראובן ציגלר, הוצאת עמותת תורת הרב, ירושלים, תשס"ד

SOLOVEITCHIK, Yosef - "U-Vikashtem Mi-Sham" in Ish HaHalakhah - Galui VeNistar, HaHistadrut HaZionit HaOlamit, Jerusalem, 1979 סולובייציק, יוסף דוב - "וביקשתם משם" ב - איש ההלכה - גלוי ונסתר, ההסתדרות הציונית העולמית, ירושלים, 1979

\section{OUTRAS FONTES}

ALTMANN, Alexander - "The Religion of the Thinkers: Free Will and Predestination in Saadia, Bahya and Maimonides" in Religion in a Religious Age, editado por S.D. Goitein, Association for Jewish Studies, Cambridge, 1974 (Ktav Publishing House, New York, 1974). 
AVERY-PECK, Alan J. - "Free Will, Fate, Providence, in Classical Judaism" in The Encyclopedia of Judaism, Vol. 1, editado por Jacob Neusner, Continuum, New York, 1999.

BACH, H.I. - The German Jew - A Synthesis of Judaism and Western Civilization 1730-1930, Oxford University Press, Oxford, 1984

BALENTINE, Samuel E. - The Hidden God - The Hiding of the Face of God in the Old Testament, Oxford University Press, Oxford, 1983

BARON, Salo - "The Modern Age" in Great Ages and Ideas of the Jewish People, Random House, New York, 1956

BASKIN, Judith R. - Pharaoh's Counsellors - Job, Jethro, and Balaam in Rabbinic and Patristic Tradition, Scholar Press, Chico, 1983

BAUM, Gregory - "Rethinking the Church's Mission after Auschwitz" in Auschwitz: Beginning of a New Era? - Reflections on the Holocaust, editado por Eva Fleischner, Ktav Publishing House, New York, 1977.

BEA, Augustin Cardinal - The Church and the Jewish People, Harper \& Row, New York, 1966.

BELITSKY, Helen Mintz - "Profile - Irving Greenberg" in Hadassah, December, 2001

BEN-MENAHEM, Hanina - "Controversy and Dialogue in the Jewish Tradition: An Interpretive Essay" in Controversy and Dialogue in the Jewish Tradition, editado por hanina Ben-Menahem, Neil S. Hecht e Shai Wosner, Routledge, London, 2005.

BEN-SASSON, Haim Hillel - "Kiddush Ha-Shem and Hillul Ha-Shem" in Encyclopaedia Judaica, Keter Publishing House, Jerusalem, 1972.

BEN-SASSON, Haim H. - "Poland" in Encyclopaedia Judaica, Vol. 13, Keter Publishing House, Jerusalem, 1974.

BERGER, Michael S. - "U-Vikashtem Mi-Sham: Rabbi Joseph B. Soloveitchik's Response to Martin Buber's Religious Existentialism” in Modern Judaism, Volume 18, Number 2, Baltimore, May 1998

BESDIN, Abraham (editor) - Man of Faith in the Modern World - Reflections of the

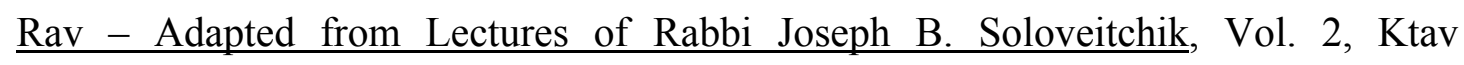
Publishing House, New Jersey, 1989

BESDIN, Abraham (editor) - Reflections of the Rav - Lessons in Jewish Thought Adapted from Lectures of Rabbi Joseph B. Soloveitchik, Vol. 1, Ktav Publishing House, New Jersey, 1993 
BRAITERMAN, Zachary - God After Auschwitz - Tradition and Change in PostHolocaust Jewish Thought, Princeton University Press, Princeton, 1998

BRETTLER, Marc - "Is There Martyrdom in the Hebrew Bible?" in Sacrificing the Self - Perspectives on Martyrdom and Religion, editado por Margaret Cormack, Oxford University Press, Oxford, 2002.

BRIGHT, John - A History of Israel, Westminster John Knox Press, Louisville, 2000.

BRIGHT, John - Covenant and Promise, SCM Press, London, 1977

BULKA, Reuven P. - "Different Paths, Common Thrust - The Shoalogy of Berkovits and Frankl" in Tradition, Vol. 19, No. 4, Winter 1981

CAPLAN, Kimmy - "The Holocaust in Contemporary Israeli Haredi Popular Religion” in Modern Judaism, Vol. 22, Number 2, May 2002

COHEN, Abraham - Everyman's Talmud - The Major Teachings of the Rabbinic Sages, Schoken Books, New York, 1995

COHEN, Arthur e MENDES-FLOHR, Paul (editores) - Contemporary Jewish Religious Thought, The Free Press, New York, 1987

COHEN, Arthur - "Theology" in Contemporary Jewish Religious Thought, editado por Arthur A. Cohen e Paul Mendes-Flohr, The Free Press, New York, 1987

COHEN, Gerson D. - "Hannah and Her Seven Sons" in Encyclopaedia Judaica, Keter, Jerusalem, 1974.

COHEN, Shaye J.D. - "The Destruction: From Scripture to Midrash" in Prooftexts, Vol. 2, Number 1, January 1982, The John Hopkins University Press, Maryland.

COHN-SHERBOK, Dan - Fifty Key Jewish Thinkers, Routledge, London, 1997

COHN-SHERBOK, Dan - Holocaust Theology - A Reader, University of Exeter Press, Exeter, 2002

COHON, Samuel S. - Jewish Theology - A Historical and Systematic Interpretation of Judaism and Its Foundations, Assen, Netherlands, 1971

COVER, Robin C. - "Sin, Sinners" in The Anchor Bible Dictionary, Vol. 6, editado por David Noel Freedman, Doubleday, New York, 1992.

DAVIES, Alan - "The Holocaust and Christian Thought" in Jewish - Christian Encounters over the Centuries - Symbiosis, Prejudice, Holocaust, Dialogue, editado por Marvin Perry e Frederick M. Schweitzer, Peter Lang, New York, 1994.

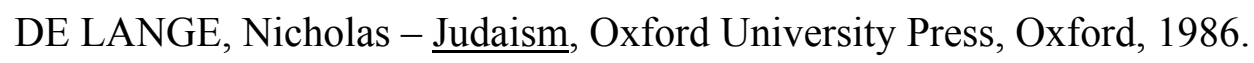

DHORME, E. - A Commentary on the Book of Job, Thomas Nelson and Sons, London, 1967 
DUBNOW, Simon - Jewish History - An Essay in the Philosophy of History, MacMillan \& Co, London, 1903

DULLES, Avery Robert - The Holocaust, Never to be Forgotten: Reflections on the Holy See's Document We Remember, Paulist Press, New York, 2001.

EICHRODT, Walther - Theology of the Old Testament, Vol. 1, SCM Press, London, 1975

EISEN, Arnold M. - The Chosen People in America - A Study in Jewish Religious Ideology, Indiana University Press, Bloomington, 1983

EISEN, Arnold - "Jewish Theology in North America - Notes on Two Decades" in Judaism Transcends Catastrophe - God, Torah and Israel beyond the Holocaust, editado por Jacob Neusner, Vol. V, Mercer University Press, Georgia, 1996

ELIADE, Mircea - The Myth of the Eternal Return, Pantheon Books, New York, 1954

EPSTEIN, Isidore - The Faith of Judaism, The Soncino Press, London, 1960

EPSTEIN, Joseph (editor) - Shiurei HaRav - A Conspectus of the Public Lectures of

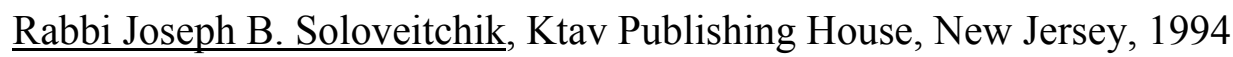

ESHKOLI, Hava - "Destruction Becomes Creation: The Theological Reaction of National Religious Zionism in Palestine to the Holocaust" in Holocaust and Genocide Studies, Vol. 17, Number 3, Winter 2003, Oxford University Press

FACKENHEIM, Emil - God's Presence in History: Jewish Affirmations and Philosophical Reflections, Harper and Row, New York, 1972

FACKENHEIM, Emil L. - "Holocaust" in Contemporary Jewish Religious Thought, editado por Arthur A. Cohen e Paul Mendes-Flohr, The Free Press, New York, 1987 FELD, Edward - The Spirit of Renewal - Finding Faith after the Holocaust, 1994, citado in Cohn-Sherbok, Dan - Holocaust Theology - A Reader, University of Exeter Press, Exeter, 2002

FINGUERMAN, Ariel - A Eleição de Israel - Um Estudo Histórico-Comparativo sobre a Doutrina do "Povo Eleito", Humanitas, São Paulo, 2003

FINKELSTEIN, Israel e SILBERMAN, Neil Asher - The Bible Unearthed, The Free Press, New York, 2001.

FIRESTONE, Reuven - "Martyrdom" in Encyclopedia of Religion and War, editado por Gabriel Palmer-Fernandez, Routledge, New York, 2004.

FISHER, Eugene J. - "How Have the Churches Responded to the Holocaust?" in The Holocaust and the Christian World - Reflections on the Past, Challenges for the 
Future, editado por Carol Rittner, Stephen D. Smith e Irena Steinfeldt, Kuperard, Great Britain, 2000

FOHRER, Georg - Estruturas Teológicas Fundamentais do Antigo Testamento, Edições Paulinas, São Paulo, 1982

FORD, David - "Theology" in The Routledge Companion to the Study of Religion, editado por John Hinnells, Routledge, London, 2005.

FOX, Marvin - "Berkovits' Treatment of the Problem of Evil", Tradition, Spring 1974

FREEMAN, Gordon M. - The Heavenly Kingdom - Aspects of Political Thought in the Talmud and Midrash, University Press of America, 1986

FRIEDMAN, Richard Elliott - Who Wrote the Bible?, Harper \& Row, New York, 1989

FRIEDMAN, Richard E. - The Disappearance of God - A Divine Mystery, Little, Brown and Company, Boston, 1995

FRIEDMAN, Theodore - "Job - The Message and Meaning" in Encyclopaedia Judaica, Vol. 10, Keter Publishing House, Jerusalem, 1971

GARBER, Zev and ZUCKERMAN, Bruce - "Why do We Call the Holocaust "The Holocaust?" - An Inquiry into the Psychology of Labels" in Remembering for the Future, Pergamon Press, Oxford, 1988

GILLMAN, Neil - "Philosophy and Theology" in The State of Jewish Studies, editado por Shaye Cohen e Edward Greenstein, Wayne State University Press, Detroit, 1990.

GILLMAN, Neil - $\underline{\text { Sacred Fragments }}$ citado in Holocaust Theology - A Reader, editado por Dan Cohn-Sherbok, University of Exeter Press, Exeter, 2002

GIULIANI, Massimo - Theological Implications of the Shoah, Peter Lang, New York, 2002

GLATZER, Nahum N. - "The Book of Job and Its Interpreters" in Biblical Motifs -

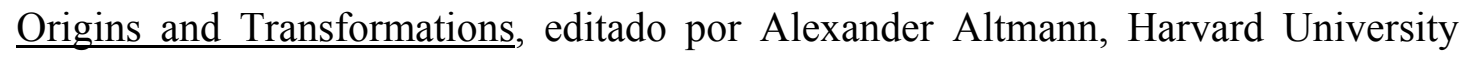
Press, Cambridge, 1966

GLATZER, Nahum N. - The Dimensions of Job - A Study and Selected Readings, Schocken Books, New York, 1969

GOLDENBERG, Robert - "Early Rabbinic Explanations of the Destruction of Jerusalem" in Journal of Jewish Studies, Vol. XXXIII, Nos. 1-2, The Oxford Centre for Postgraduate Hebrew Studies, Oxford, Spring-Autumn 1982 
GRAUPE, Heinz Moshe - The Rise of Modern Judaism - An Intellectual History of German Jewry 1650-1942, Robert E. Krieger Publishing, New York, 1978

GREENBERG, Gershon - "Redemption After Holocaust According to Mahane Israel - Lubavitch 1940-1945" in Modern Judaism, Vol. 12, The Johns Hopkins University Press, Baltimore, 1992

GREENBERG, Gershon - "Jewish Religious Thought in the Wake of the Catastrophe" in Thinking in the Shadow of Hell - The Impact of the Holocaust on Theology and Jewish-Christian Relations, editado por Jacques B. Doukhan, Andrews University Press, Michigan, 2002

GROSS, Netty - "Why did God do This to Us - Ultra-Orthodox Jews Finally Grapple with the Holocaust" in The Jerusalem Report, May, 2000

GUROCK, Jeffrey S. - American Jewish Orthodoxy in Historical Perspective, Ktav Publishing House, New Jersey, 1996

GUTTMANN, Julius - Philosophies of Judaism - The History of Jewish Philosophy from Biblical Times to Franz Rosenzweig, Holt, Rinehart and Winston, New York, 1964

HABEL, Norman C. - The Book of Job - A Commentary, SCM Press, London, 1985

HAIM, Abraham - "History" in Encyclopaedia Judaica, Vol. 8, Keter Publishing House Ltd, Jerusalem, 1971

HALBERTAL, Moshe - People of the Book - Canon, Meaning, and Authority, Harvard University Press, Cambridge, 1997.

HALEVY, Elimelech E. - "Amalekites" in Encyclopaedia Judaica, Vol. 2, Keter Publishing House, Jerusalem, 1971

HALKIN, Hillel - "Berkovits" in Encyclopaedia Judaica, Vol. 4, Keter Publishing House, Jerusalem, 1972

HARTLEY, John E. - The Book of Job, William B. Eerdmans Publishing Company, Grand Rapids, 1988

HARTMAN, David - "The Halakhic Hero: Rabbi Joseph Soloveitchik, Halakhic Man” in Modern Judaism, Vol. 9, Number 3, The John Hopkins University Press, Baltimore, 1989

HARTMAN, David - A Heart of Many Rooms - Celebrating the Many Voices Within Judaism, Jewish Lights Publishing, Vermont, 1999

HARTMAN, David - A Living Covenant - The Innovative Spirit in Traditional Judaism, The Free Press, New York, 1985 
HARTMAN, David - Love and Terror in the God Encounter - The Theological Legacy of Rabbi Joseph B. Soloveitchik, Jewish Lights Publishing, Woodstock, 2004 HARTMAN, David - "Perceptions of the State of Israel in Modern Halakhic Thinkers" in Immanuel, 22/23, 1989

HAZONY, David - "Eliezer Berkovits" in Encyclopaedia Judaica, $2^{\text {nd }}$ Edition, Vol. 3, Keter Publishing House, Jerusalem, 2007

HAZONY, David - "Eliezer Berkovits, Theologian of Zionism" in Azure, Spring, Number 17, The Shalem Center, Jerusalem, 2004

HAZONY, David (editor) - Essential Essays on Judaism (Eliezer Berkovits), Shalem Press, Jerusalem, 2002

HAYNES, Stephen R. - "Christian Theology After Auschwitz" in Thinking in the Shadow of Hell - The Impact of the Holocaust on Theology and Jewish-Christian $\underline{\text { Relations, }}$ editado por Jacques B. Doukhan, Andrews University Press, Michigan, 2002.

HAYNES, Stephen R. - "Protestant Responses to the Holocaust" in The Holocaust and the Christian World - Reflections on the Past, Challenges for the Future, editado por Carol Rittner, Stephen D. Smith e Irena Steinfeldt, Kuperard, Great Britain, 2000 HEILMAN, Samuel C. e COHEN, Steven M. - Cosmopolitans \& Parochials Modern Orthodox Jews in America, The University of Chicago Press, Chicago, 1989 HEILMAN, Samuel, C. - "The Many Faces of Orthodoxy”, Part I, Modern Judaism, Vol. 2, Number 1, The John Hopkins University Press, Baltimore, Fevereiro 1982.

HEILMAN, Samuel, C. - “The Many Faces of Orthodoxy”, Part II, Modern Judaism, Vol. 2, Number 2, The John Hopkins University Press, Baltimore, Maio 1982.

HELLIG, Jocelyn - "Richard L. Rubenstein" in Interpreters of Judaism in the Late Twentieth Century, editado por Steven Katz, B'nai B'rith Books, Washington, 1993

HERFORD, R. Travers (editor) - The Ethics of the Talmud: Sayings of the Fathers, Schocken Books, New York, 1966

HERR, Moshe David - "Edom" in Encyclopaedia Judaica, Vol. 6, Keter, Jerusalem, 1972.

HERR, Moshe David - "The Ten Martyrs", Encyclopaedia Judaica, Keter, Jerusalem, 1978.

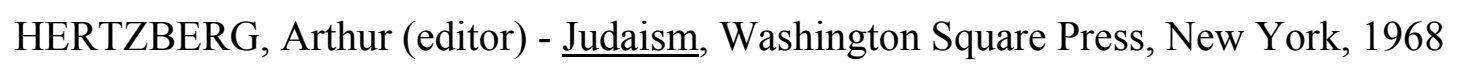
HERTZBERG, Arthur (editor) - The Zionist Idea: A Historical Analysis and Reader, Atheneum, New York, 1971 
HILLERS, Delbert R. - Covenant: The History of a Biblical Idea, The John Hopkins Press, Baltimore, 1969

HILLERS, Delbert R. - "Covenant" in The Encyclopedia of Religion, editado por Mircea Eliade, Vol. 4, MacMillan Publishing Company, New York, 1987

HOENIG, Samuel N. - The Essence of Talmudic Law and Thought, Jason Aronson Inc., New Jersey, 1993

HYMAN, Arthur - "Aspects of the Medieval Jewish and Islamic Discussion of 'Free Choice" in Freedom and Moral Responsibility - General and Jewish Perspectives, editado por Charles H. Manekin, University Press of Maryland, 1997.

ISAAC, Jules - The Teaching of Contempt - Christian Roots of Anti-Semitism, McGraw-Hill Book Company, New York, 1965.

JACOBS, Louis - A Jewish Theology, Behrman House Publishers, New York, 1973. JACOBS, Louis - "Judaism" in Encyclopaedia Judaica, Vol. 10, Keter Publishing House, Jerusalem, 1971

JACOBS, Louis - "Theology" in Encyclopaedia Judaica, Keter Publishing House, Jerusalem, 1972.

JACOBS, Steven L. - "Judaism and Christianity After Auschwitz" in Contemporary Jewish Religious Responses to the Shoah, editado por Steven Jacobs, University Press of America, New York, 1993

JAKOBOVITS, Immanuel - "Some Personal, Theological and Religious Responses to the Holocaust" in Remembering for the Future, Pergamon Press, Oxford, 1988 JOSEPHUS - Jewish Antiquities, traduzido por Ralph Marcus, Volume VII, Harvard University Press, Cambridge, 1957.

KAPLAN, Lawrence - "Revisionism and the Rav: The Struggle for the Soul of Modern Orthodoxy" in Judaism, No 191, Vol. 48, Number 3, Summer, Nova York, 1999

KAPLAN, Mordecai M. - "Rabbinic Judaism" in Understanding Rabbinic Judaism, editado por Jacob Neusner, Ktav Publishing House, New York, 1974

KATZ, Jacob - Emancipation and Assimilation, Gregg International, Westmead, 1972

KATZ, Jacob - Exclusiveness and Tolerance - Studies in Jewish-Gentile Relations in Medieval and Modern Times, Schocken Books, New York, 1973.

KATZ, Jacob - A House Divided - Orthodoxy and Schism in Nineteenth-Century Central European Jewry, Brandeis University Press, Hanover, 1998 
KATZ, Jacob - "Orthodoxy in Historical Perspective" in Studies in Contemporary Jewry II, editado por Peter Medding, Bloomington, 1986

KATZ, Simha - "Samson Raphael Hirsch" in Encyclopaedia Judaica, Vol. 8, Keter Publishing House, Jerusalem, 1974.

KATZ, Steven T. - The Holocaust in Historical Context, Oxford University Press, Oxford, 1994

KATZ, Steven T. - "The Holocaust: Jewish Theological Responses" in The Encyclopedia of Religion, editado por Mircea Eliade, Vol. 6, MacMillan Publishing Company, New York, 1987

KATZ, Steven T. - The Impact of the Holocaust on Jewish Theology, New York University Press, New York, 2005.

KATZ, Steven T. - "Irving Greenberg" in Interpreters of Judaism in the Late Twentieth Century, B'nai B'rith Books, Washington, 1993

KATZ, Steven T. - $\underline{\text { Post-Holocaust Dialogues - Critical Studies in Modern Jewish }}$ Thought, New York University Press, New York, 1983

KATZ, Steven T. - "Response" in The State of Jewish Studies, editado por S. Cohen, Wayne State University Press, Detroit, 1990

KATZBURG, Nathaniel - "Orthodoxy" in Encyclopaedia Judaica, Vol. 12, Keter Publishing House, Jerusalem, 1974.

KAUFMAN, William - "Time" in Contemporary Jewish Religious Thought, editado por Arthur A. Cohen e Paul Mendes-Flohr, The Free Press, New York, 1987

KAUFMANN, Yehezkel - The Religion of Israel, traduzido e editado por Moshe Greenberg, The University of Chicago Press, Chicago, 1963

KELLNER, Menachem - "Chosenness, not Chauvinism: Maimonides on the Chosen People" in A People Apart - Choosenness and Ritual in Jewish Philosophical Thought, editado por Daniel H. Frank, State University of New York Press, Albany, 1993

KEPNES, Steven - "Job and Post-Holocaust Theodicy" in Strange Fire - Reading the Bible After the Holocaust, editado por Tod Linafelt, Sheffield Academic Press, Sheffield, 2000

KNAUF, Ernst Axel - “Does 'Deuteronomistic Historiography' (DtrH) Exist?” in Israel Constructs its History - Deuteronomistic Historiography in Recent Research, editado por Albert de Pury, Thomas Romer e Jean-Daniel Macchi, Sheffield Academic Press, Sheffield, 2000. 
KOCHAN, Lionel - The Jew and his History, The MacMillan Press, London, 1977

KOHLER, Kaufman - Jewish Theology - Systematically and Historically

Considered, The Macmillan Company, New York, 1918

KOHLER, Kaufmann - Jewish Theology, The MacMillan Company, New York, 1928, citado in Hertzberg, Judaísmo, Zahar Editores, Rio de Janeiro, 1964

KOHLER, Kaufmann - "The Mission of Israel” in Contemporary Jewish Thought, editado por Simon Noveck, Vision Press Ltd, London, 1964

KRAEMER, David - Responses to Suffering in Classical Rabbinic Literature, Oxford University Press, Oxford, 1995.

KRAUT, Benny - "Faith and the Holocaust" in Judaism, Vol. 31, Number 2, The American Jewish Congress, New York, Spring 1982

KUSHNER, Harold S. - When Bad Things Happen to Good People, Avon Books, New York, 1983

LEAMAN, Oliver - Evil and Suffering in Jewish Philosophy, Cambridge University Press, Cambridge, 1995

LELYVELD, Arthur - "The Theological 'Problem of Evil' and the Holocaust" in Remembering for the Future, Pergamon Press, Oxford, 1988

LEVENTHAL, Barry - Theological Perspectives on the Holocaust, Dissertation presented to the Dallas Theological Seminary, 1982

LEVY, Ze'ev - “Judaism and Chosenness: On Some Controversial Aspects from Spinoza to Contemporary Jewish Thought" in A People Apart - Chosenness and

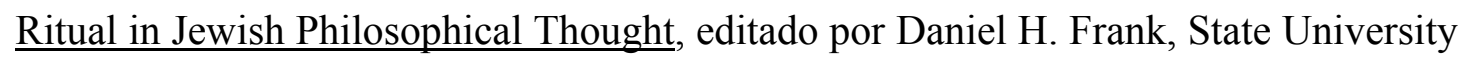
of New York Press, Albany, 1993

LIBERLES, Robert - Religious Conflict in Social Context - The Resurgence of Orthodox Judaism in Frankfurt Am Main 1838-1877, Greenwood Press, Connecticut, 1985

LIEBMAN, Charles and COHEN, Steven - Two Worlds of Judaism - The Israeli and American Experiences, Yale University Press, New Haven, 1990

LIEBMAN, Charles - "Orthodox Judaism" in The Encyclopedia of Religion, editado por Mircea Eliade, Vol. 11, MacMillan Publishing Company, New York, 1987

LIEBMAN, Charles S. - "Orthodox Judaism Today” in Midstream, Vol. XXV, № 7, August/September, New York, 1979

LIPSTADT, Deborah E. - "The Holocaust" in Literature of the Holocaust, editado por Harold Bloom, Chelsea House Publishers, Philadelphia, 2004 
LOVELEY, E. - "Election" in New Catholic Encyclopedia, Vol. V, The Catholic University of America, Washington, 1967

LUSTIGER, Arnold - Before Hashem You Shall be Purified - Rabbi Joseph B. Soloveitchik on the Days of Awe, Ohr Publishing, 1998

MACCOBY, Hyam - "Sanctification of the Name" in Contemporary Jewish Religious Thought, editado por Arthur Cohen and Paul Mendes-Flohr, The Free Press, New York, 1987

MANEKIN, Charles H. (editor) - Freedom and Moral Responsibility - General and Jewish Perspectives, University Press of Maryland, 1997.

MARCUS, Ivan G. - "From Politics to Martyrdom - Shifting Paradigms in the Hebrew Narratives of the 1096 Crusade Riots" in Prooftexts, Vol. 2, Number 1, January 1982, The John Hopkins University Press, Maryland.

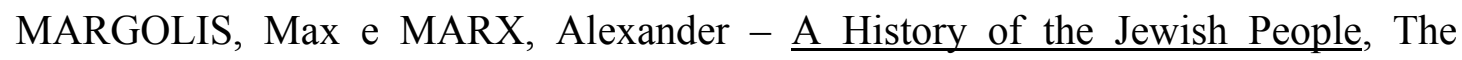
Jewish Publication Society of America, Philadelphia, 1967.

McCARTHY, Dennis J. - Treaty and Covenant, Pontifical Biblical Institute, Roma, 1963

McCARTHY, Dennis J. - Old Testament Covenant - A Survey of Current Opinions, Basil Blackwell, Oxford, 1972

MENDES-FLOHR, Paul - "History" in Contemporary Jewish Religious Thought, editado por Arthur A. Cohen e Paul Mendes-Flohr, The Free Press, New York, 1987 MENDES-FLOHR, Paul - "Jewish Philosophy and Theology" in The Oxford Handbook of Jewish Studies, editado por Martin Goodman, Oxford University Press, Oxford, 2002.

MEYER, Michael A. - Ideas of Jewish History, Behrman House, New York, 1974

MEYER, Michael A. - The Origins of the Modern Jew - Jewish Identity and European Culture in Germany 1749-1824, Wayne State University Press, Detroit, 1967

MEYER, Michael A. - "Reform Judaism" in The Encyclopedia of Religion, Vol. 12, MacMillan Publishing Company, New York, 1987

MICHMAN, Dan - "The Holocaust and the State of Israel" in The Impact of the Holocaust on Jewish Theology, editado por Steven T. Katz, New York University Press, New York, 2005.

MICHMAN, Dan - "The Impact of the Holocaust on Religious Jewry" in Major Changes Within the Jewish People in the Wake of the Holocaust - Proceedings of the 
Ninth Yad Vashem International Historical Conference, editado por Yisrael Gutman, Yad Vashem, Jerusalem, 1996

MINTZ, Alan - "Catastrophe" in Contemporary Jewish Religious Thought, editado por Arthur A. Cohen e Paul Mendes-Flohr, The Free Press, New York, 1987

MINTZ, Alan - Hurban - Responses to Catastrophe in Hebrew Literature, Columbia University Press, New York, 1984

MOORE, James F. - "A Spectrum of Views: Traditional Christian Responses to the Holocaust" in Journal of Ecumenical Studies, 25:2, Spring 1988, Temple University, Philadelphia.

MORGAN, Michael - Beyond Auschwitz - Post-Holocaust Jewish Thought in America, Oxford University Press, Oxford, 2001

MORGAN, Michael - Dilemmas in Modern Jewish Thought - The Dialectics of

Revelation and History, Indiana University Press, 1992

MORGAN, Michael - "To Seize Memory - History and Identity in Post-Holocaust Jewish Thought" in Thinking about the Holocaust - After Half a Century, editado por Alvin H. Rosenfeld, Indiana University Press, Bloomington, 1997

MUNK, Reinier - The Rationale of Halakhic Man - Joseph B. Soloveitchik's Conception of Jewish Thought, J.C. Gieben, Amsterdam, 1996

NADLER, Allan Lawrence - "On Eliezer Berkovits 'Not in Heaven - The Nature and Function of Halakha"', Tradition, Vol. 21, No. 3, 1984

NADLER, Allan L. - "Piety and Politics: The Case of the Satmer Rebbe" in Judaism, Vol. 31, No. 121, Number 2, Spring 1982

NEHER, André - The Exile of the Word - From the Silence of the Bible to the Silence of Auschwitz, The Jewish Publication Society of Amarica, Philadelphia, 1981 NEUSNER, Jacob - Formative Judaism - History Hermeneutics, Law and Religion Ten Recent Essays, Global Publications, Binghamton, 2000

NEUSNER, Jacob (editor) - Judaism Transcends Catastrophe - God, Torah and Israel beyond the Holocaust, Vols. I, II, III, IV, V, Mercer University Press, Georgia, 1996 NEUSNER, Jacob - Understanding Jewish Theology - Classical Issues and Modern Perspectives, Global Publications, Binghamton University, Binghamton, 2001

NEUSNER, Jacob (editor) - Understanding Rabbinic Judaism - From Talmudic to Modern Times, Ktav Publishing House Inc., New York, 1974

NEWSOM, Carol A. - "The Book of Job" in The New Interpreter's Bible, Vol. IV, Abingdon Press, Nashville, 1996 
NOVAK, David - "Contemporary Jewish Theology" in Judaism Transcends Catastrophe - God, Torah and Israel Beyond the Holocaust, editado por Jacob Neusner, Vols. V, Mercer University Press, Georgia, 1996

NOVAK, David - The Election of Israel - The Idea of the Chosen People, Cambridge University Press, Cambridge, 1995

OBRECHT, Peggy - "After the Shoah: Christian Statements of Contrition" in The Holocaust and the Christian World - Reflections on the Past, Challenges for the Future, editado por Carol Rittner, Stephen D. Smith e Irena Steinfeldt, Kuperard, Great Britain, 2000

OFER, Dalia - "The Use of the Term 'Shoah"” in Avar Ve'Atid, The Joint Authority for Jewish-Zionist Education, Jerusalem, 1996.

PATAI, Raphael - The Jewish Mind, Charles Scribner's Sons, New York, 1977

PATAI, Raphael - The Jewish Mind, Wayne State University Pres, Detroit, 1996

PELI, Pinchas - Soloveitchik On Repentance, Paulist Press, New York, 1984

PERSON Jr, Raymond F. - The Deuteronomic School - History, Social Setting, and Literature, Society of Biblical Literature, Atlanta, 2002.

PINES, Shlomo - "Free Will" in Encyclopaedia Judaica - $2^{\text {nd }}$ Edition, Vol. 7, Thomson Gale, Detroit, 2007.

PLAUT, G. - The Growth of Reform Judaism, World Union for Progressive Judaism, New York, 1965

POLIAKOV, Léon - The History of Anti-Semitism (Vol. I) - From Roman Times to the Court Jews, Routledge \& Kegan Paul, London, 1974

POLIAKOV, Léon - The History of Anti-Semitism (Vol. II) - From Mohammed to the Marranos, Routledge \& Kegan Paul, London, 1974

POPE, Marvin H. - Job - The Anchor Bible, Doubleday \& Company, New York, 1974

RACKMAN, Emanuel - One Man's Judaism - Renewing the Old and Sanctifying the New, Gefen Publishing House, Jerusalem, 2000

RACKMAN, Emanuel - "Orthodox Judaism" in Contemporary Jewish Religious Thought, editado por Arthur A. Cohen e Paul Mendes-Flohr, The Free Press, New York, 1987

RAFFEL, Charles - "Eliezer Berkovits" in Interpreters of Judaism in the Late Twentieth Century, editado por Steven T. Katz, B'nai B'rith Books, Washington, 1993 
RAPHAEL, Marc Lee - Profiles in American Judaism - The Reform, Conservative, Orthodox, and Reconstructionist Traditions in Historical Perspective, Harper \& Row Publishers, Cambridge, New York, 1984.

RAPPAPORT, Uriel - "Hadrian" in Encyclopaedia Judaica - $2^{\text {nd }}$ Edition, Vol. 8, MacMillan, Detroit, 2007.

RATZABI, Shalom - "Judaism, Exile and the State of Israel in Postwar American Jewish Theological Discourse" in Who Owns Judaism? - Public Religion and Private Faith in America and Israel, editado por Eli Lederhendler, Oxford University Press, New York, 2001

REYNOLDS, Thomas E. - "Religion Within the Limits of History: Schleiermacher and Religion - A Reappraisal” in Religion, Academic Press, Volume 32, Number 1, January 2002

RITTNER, Carol; SMITH, Stephen D.; STEINFELDT, Irena - The Holocaust and the Christian World - Reflections on the Past, Challenges for the Future, Yad Vashem International School for Holocaust Studies, Kuperard, Great Britain, 2000.

ROOS, Lena - God Wants It - The Ideology of Martyrdom of the Hebrew Crusade Chronicles and Its Jwish and Christian Background, Tese de Doutoramento, Universidade Uppsala, Akademitryck AB, Edsbruk, 2003.

ROSENAK, Michael - "State of Israel” in Contemporary Jewish Religious Thought, editado por Arthur A. Cohen e Paul Mendes-Flohr, The Free Press, New York, 1987

ROSENBERG, Bernard e GOLDSTEIN, Ernest - Creators and Disturbers Reminiscences by Jewish Intellectuals of New York, Columbia University Press, New York, 1982

ROSENBERG, Shalom - "Exile and Redemption in Jewish Thought in the Sixteenth Century" in Jewish Thought in the Sixteenth Century, editado por Bernard Dov Cooperman, Harvard University Press, Cambridge, 1983.

ROSKIES, David G. - Against the Apocalypse - Responses to Catastrophe in Modern Jewish Culture, Harvard University Press, Cambridge, 1984

ROTH, John K. - "What Does the Holocaust Have to Do with Christianity?" in The Holocaust and the Christian World - Reflections on the Past, Challenges for the Future, editado por Carol Rittner, Stephen D. Smith e Irena Steinfeldt, Kuperard, Great Britain, 2000

ROTHKOFF, Aaron - “Joseph Dov Soloveitchik” in Encyclopaedia Judaica, Vol. 15, Keter, Jerusalem, 1972 
ROTHKOFF, Aaron e SCHWARTZ, Dov - "Joseph Dov Soloveitchik" in Encyclopaedia Judaica, $2^{\text {nd }}$ Edition, Vol. 18, Keter Publishing House, Jerusalem, 2007

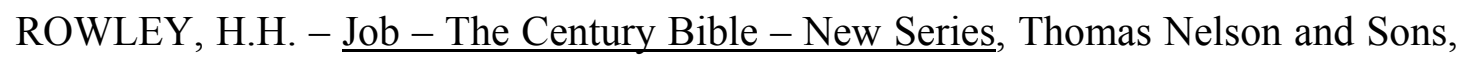
Great Britain, 1970

RUBENSTEIN, Richard L. - "Job and Auschwitz" in Strange Fire - Reading the Bible After the Holocaust, editado por Tod Linafelt, Sheffield Academic Press, Sheffield, 2000

RUDIN, A. James - "Flashpoints of Catholic-Jewish Relations" in The Holocaust and the Christian World - Reflections on the Past, Challenges for the Future, editado por Carol Rittner, Stephen D. Smith e Irena Steinfeldt, Kuperard, Great Britain, 2000

SACHAR, Howard Morley - The Course of Modern Jewish History, Dell Publishing, New York, 1958

SACKS, Jonathan - Crisis and Covenant - Jewish Thought after the Holocaust, Manchester University Press, Manchester, 1993

SACKS, Jonathan - Tradition in an Untraditional Age, Vallentine Mitchell, London, 1990, citado in Cohn-Sherbok, Dan - Holocaust Theology - A Reader, University of Exeter Press, Exeter, 2002

SAFRAI, Shmuel - "Epoca de la Misna y el Talmud" in Historia del Pueblo Judío, editado por H.H. Ben-Sasson, Alianza Editorial, Madrid, 1988

SAMET, Moshe S. - "Neo-Orthodoxy" in Encyclopaedia Judaica, Vol. 12, Keter Publishing House, Jerusalem, 1974.

SAWYER, John F.A. - Prophecy and the Biblical Prophets, Oxford University Press, Oxford, 1993.

SCHECHTER, Solomon - Aspects of Rabbinic Theology, Schocken Books, New York, 1961

SCHILDENBERGER, Johannus. - "Covenant" in Encyclopedia of Biblical Theology, editado por Johannes Bauer, Vol. I, Sheed and Ward, London, 1970

SCHINDLER, Pessach - "Theological Encounters with God and Man During the Shoah" in The $9^{\text {th }}$ Annual Israel Goldstein Holocaust Lecture, Jerusalem, 1992

SCHOLEM, Gershom - Sabbatai Sevi - The Mystical Messiah, Princeton University Press, Prinecton, 1975.

SCHWARTZ, Seth - "Historiography on the Jews in the 'Talmudic Period' (70-640 ce)" in The Oxford Handbook of Jewish Studies, editado por Martin Goodman, Oxford University Press, Oxford, 2002. 
SCHWEID, Eliezer - "The Impact of the Holocaust on Haredi Thought" in Avar Ve'Atid, Vol. 3, No. 1, September, The Joint Authority for Jewish-Zionist Education, Jerusalem, 1996

SCHWEID, Eliezer - Jewish Thought in the 20th Century - An Introduction, Scholar Press, Atlanta, 1992

SCHWEID, Eliezer - Wrestling Until Day-Break - Searching for Meaning in the Thinking on the Holocaust, University Press of America, New York, 1994

SEESKIN, Kenneth - "Emil Fackenheim" in Interpreters of Judaism in the Late Twentieth Century, editado por Steven Katz, B'nai B'rith Books, Washington, 1993 SELTZER, Robert - "History - Jewish Views" in The Encyclopedia of Religion, editado por Mircea Eliade, Vol. 6, MacMillan Publishing Company, New York, 1987. SHATZ, David - "Commentary - Interpretive Pluralism" in The Jewish Political Tradition, Vol. 1, editado por Michael Walzer, Yale University Press, New Haven, 2000.

SILBERMAN, Lou H. - "Chosen People"in Encyclopaedia Judaica, Vol. 5, Keter Publishing House Ltd, Jerusalem, 1971

SILVER, Daniel J. - "Heresy" in Encyclopaedia Judaica, Keter Publishing House Ltd, Jerusalem, 1971

SIMON, Marcel - Verus Israel: A Study of the Relations between Christians and Jews in the Roman Empire (AD 135-425), The Littman Library of Jewish Civilization, London, 1996

SINGER, Aharon - "Soloveitchik's Lonely Man of Faith" in Thinkers and Teachers of Modern Judaism, editado por Raphael Patai e Emanuel Goldsmith, Paragon House, New York, 1994

SINGER, David - “The Case for an 'Irrelevant' Orthodoxy: An Open Letter to Yitzchak Greenberg" in Tradition, Vol. 11, No. 2, Summer, 1970

SINGER, David - "Joseph Soloveitchik" in Interpreters of Judaism in the Late Twentieth Century, editado por Steven T. Katz, B'nai B'rith Books, Washington, 1993

SINGER, David e SOKOL, Moshe - "Joseph Soloveitchik: Lonely Man of Faith" in Modern Judaism, Vol. 2, Number 3, October, Baltimore, 1982

SINGER, David - "The New Orthodox Theology" in Modern Judaism, Vol. 9, Number 1, February, The John Hopkins University Press, 1989 
SKLAR, Jay - Sin, Impurity, Sacrifice, Atonement - The Priestly Conceptions, Sheffield Phoenix Press, Sheffield, 2005.

SLONIMSKY, Henry - “Judah Halevi” in Understanding Rabbinic Judaism, editado por Jacob Neusner, Ktav Publishing House, New York, 1974

SNAITH, Norman H. - The Distinctive Ideas of the Old Testament, The Epworth Press, London, 1950

SOGGIN, J. Alberto - Introduction to the Old Testament - From its Origins to the Closing of the Alexandrian Canon, SCM Press Ltd, London, 1980

SOKOL, Moshe - "Joseph B. Soloveitchik (1903-1993)" in American Jewish Year Book, The American Jewish Committee, New York, 1995

SOLOMON, Norman - "Does the Shoah Require a Radically New Jewish Theology?" in Remembering for the Future, Pergamon Press, Oxford, 1988

SOLOVEITCHIK, Haym - "Halakhah, Hermeneutics, and Martyrdom in Medieval Ashkenaz", Part I, in The Jewish Quarterly Review, Vol 94, Number 1, University of Pennsylvania Press, Pennsylvania, Winter 2004.

SOLOVEITCHIK, Haym - "Halakhah, Hermeneutics, and Martyrdom in Medieval Ashkenaz", Part II, in The Jewish Quarterly Review, Vol 94, Number 2, University of Pennsylvania Press, Pennsylvania, Spring 2004.

SINGER, David - "Joseph Soloveitchik" in Interpreters of Judaism in the Late

Twentieth Century, editado por Steven T. Katz, B'nai B'rith Books, Washington, 1993

STEENSGAARD, P. - "Time in Judaism" in Religion and Time, editado por Anindita Balslev e J.N. Mohanty, E.J. Brill, Leiden, 1993

STEINZALTZ, Adin - Talmudic Images, Jason Aronson, Northvale, 1997

STERN, Menajem - "Periodo del Segundo Templo" in Historia del Pueblo Judío, editado por H.H. Ben-Sasson, Alianza Editorial, Madrid, 1988

STRACK, Hermann - Introduction to the Talmud and Midrash, Atheneum, New York, 1978

THOMPSON, Thomas L. - "Israelite Historiography" in The Anchor Bible Dictionary, Vol. 3, editado por David Noel Freedman, Doubleday, New York, 1992.

THROWER, James - Religion - The Classical Theories, Edinburgh University Press, Edinburgh

URBACH, Ephraim E. - "Sages" in Encyclopaedia Judaica, Vol. 14, Keter Publishing House Ltd, Jerusalem, 1971 
URBACH, Ephraim E. - The Sages - Their Concepts and Beliefs, Harvard University Press, Cambridge, 1979

WALLACE, Dewey - "Free Will and Predestination" in The Encyclopedia of

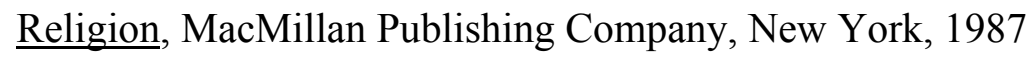

WALZER, Michael, LORBERBAUM, Menachem e ZOHAR, Noam J. - The Jewish Political Tradition, Vol. 1, Yale University Press, New Haven, 2000.

WAXMAN, Chaim I. - "From Institutional Decay to Primary Day: American Orthodox Jewry Since World War II", American Jewish History, 91.3-4, The John Hopkins University Press, 2003.

WEINFELD, Moshe - Deuteronomy and the Deuteronomic School, Eisenbrauns, Indiana, 1992.

WEISS, Saul (editor) - Insights of Rabbi Joseph B. Soloveitchik - Discourses on Fundamental Theological Issues in Judaism - Rowman \& Littlefield Publishers, New York, 2005

WELLHAUSEN, Julius- Prolegomena to the History of Ancient Israel, Meridian Books, New York, 1958

WIESEL, Elie - Night, Avon Books, New York, 1970

WINSTON, David - "Free Will” in Contemporary Jewish Religious Thought, editado por Arthur A. Cohen e Paul Mendes-Flohr, The Free Press, New York, 1987

WOLPE, David - "Hester Panim in Modern Jewish Thought" in Modern Judaism, Vol. 17, Number 1, Fevereiro 1997, The John Hopkins University Press, Baltimore.

WURZBURGER, Walter S. - "Orthodoxy” in Encyclopaedia Judaica, Vol. 12, Keter Publishing House, Jerusalem, 1974.

WYSCHOGROD, Michael - The Body of Faith - God in the People Israel, Harper \& Row, San Francisco, 1983

YERUSHALMI, Yosef Hayim - Zakhor - Jewish History and Jewish Memory, University of Washington Press, Seattle, 1982

YONICK, A. - "Covenant (in the Bible)" in New Catholic Encyclopedia, Vol. IV, The Catholic University of America, Washington, 1967

ZIMMELS, H.J. - The Echo of the Nazi Holocaust in Rabbinic Literature, Ktav Publishing House, Ireland, 1977

ZUESSE, Evan - "The Gate of God's Presence in Heschel, Buber and Soloveitchik" in Thinkers and Teachers of Modern Judaism, editado por Raphael Patai e Emanuel Goldsmith, Paragon House, New York, 1994 


\section{EM HEBRAICO}

BEN-SASSON, Haim Hillel - Toldot Israel Be-Yemei Ha-Beinaim, Dvir, Tel Aviv, 1969

$$
\text { בן-ששון, חיים הלל - תולדות ישראל בימי-הביניים, דביר, תל אביב, } 1969
$$

BROYER. Mordekhai (editor) - Torah Im Derekh Eretz - Ha-Tnuah, Ishiah,

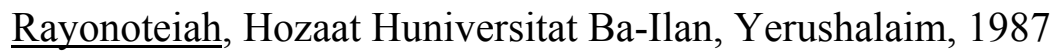

ברויאר, מרדכי (עריכה) - תורה עם דרך ארץ - התנועה, אישיה, רעיונותיה, הוצאת אוניברסיטת בר-

$$
\text { אילן, ירושלים, } 1987
$$

DAN, Yosef - "Baiat Kidush Ha-Shem Be-Toratah Ha-Yiunit Shel Tnuat Hasidut Ashkenaz" in Milhamat Kodesh U-Martirologiah Be-Toldot Israel U-Betoldot Haamim, Ha-Hevrah Ha-Historit Ha-Israelit, Jerusalem

דן, יוסף - "בעיית קידוש השם בתורתה העיונית של תנועת חסידות אשכנז", מלחמת קודש ומארטירולוגיה בתולדות ישראל ובתולדות העמים, החברה ההיסטורית הישראלית, ירושלים, תשכ"ח

EMANUEL, Yona (editor) - Harav Shimshon Raphael Hirsch - Mishnato U-Shitato, Hozaat Sefarim Pledheim, Jerusalem

עמנואל, יונה (עורך) - הרב שמשון רפאל הירש - משנתו ושיטתו, הוצאת ספרים פלדהיים, ירושלים, תשמ"ט

FRIEDMAN, Menahem - "Al HaNisim Prihato Shel Olam HaTorah (HaYeshivot VeHaKolelim) Be-Israel" in Yeshivot U-Batei Midrashot, editado por Emanuel Atkes, Merkaz Zalman Shazar, Jerusalem

פרידמן, מנחם - "על הנסים פריחתו של עולם התורה (הישיבות והכוללים) בישראל", ישיבות ובתי מדרשות, עמנואל אטקס (עורך), מרכז זלמן שזר, ירושלים, תשס"ז

GREENBERG, Gershon - Shaarit Ha-Pleitah Ve-Hashoah: Reshimat Maamarim USefarim Al Hashkafot Be-Enenei Ha-Umah Ha-Yeudit Le-Ahar Shoat Yehudei Eiropah (1944-1949), Huniversitat Ba-Ilan, Ramat Gan, 1994 גרינברג, גרשון - שארית הפליטה והשואה: רשימת מאמרים וספרים על השקפות בעניני האמונה היהודית לאחר שואת יהודי אירופה (1949-1944), אוניברסיטת בר-אילן, רמת-גן, 1994 
HARTMAN, David - "Dat Yehudit Be-Olam Hiloni" in Ptahim, Gilaion 1-2, Jerusalem

הרטמן, דוד - "דת יהודית בעולם חילוני", מתוך פתתים, גליון א - ב, ירושלים, שבט תשל"ח

HAZONY, David - "Al Eliezer Berkovits U-Torat Hamusar Ha-Yehudit" in Tkhelet, 11, Jerusalem, 2001

חזוני, דוד - "על אליעזר ברקוביץ ותורת המוסר היהודית", מתוך תכלת, 11, ירושלים, 2001

HERR, Moshe David - "Gzeirot Ha-Shmad U-Kidush Ha-Shem Be-Yemei Hadrianus" in Milhamat Kodesh U-Martirologiah Be-Toldot Israel U-Betoldot Haamim, Ha-Hevrah Ha-Historit Ha-Israelit, Jerusalem הר , משה דוד - "גזירות השמד וקידוש השם בימי הדריינוס" ב-מלחמת קודש ומארטירולוגיה בתולדות ישראל ובתולדות העמים, החברה ההיסטורית הישראלית, ירושלים, תשכ"ח.

JAPHET, Sarah - Emunot U-Deot Be-Sefer Divrei Hayamim - U-Mekoman BeOlam HaMahshevah HaMikrait, Mossad Bialik, Jerusalem, 1977 יפת, שרה - אמונות ודעות בספר דברי-הימים - ומקומן בעולם המחשבה המקראית, מוסר ביאליק, ירושלים, 1977

KATZ, Jacob - Et Lahkor Ve-Et Le-hitbonen - Masah Historit Al Darko Shel Beit Israel Meaz Zeto Mearzo Ve-Ad Shuvo Aleiah, Merkaz Zalman Shazar Le-Toldot Israel, Jerusalem

כ"ץ, יעקב - עת לחקור ועת להתבונן - מסה היסטורית על דרכו של בית ישראל מאז צאתו מארצו ועד

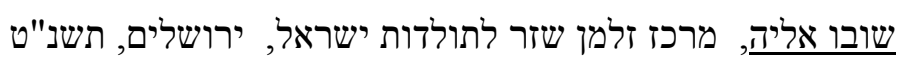

LICHTENSTEIN, Moshe - "Bekhah Et Asher Asah Lekha Amalek - Bekhi VeZikaron Be-Hitmodedut Dorenu El Mul HaShoah" in Torat Me-Zion, Jerusalem ליכטנשטיין, משה - "בכה את אשר עשה לך עמלק - בכי וזיכרון בהתמודדות דורנו אל מול השואה" ב תורת מציון, ירושלים, תשס"ב

NEEMAN, Nadav - Haavar HaMekhonen Et Hahoveh - Izuvah Shel HaHistoriografia HaMikrait Be-Sof Yemei HaBait HaRishon U-Leahar HaHurban, Hozaat Arnah Hess, Jerusalem, 2002 
נאמן, נדב - העבר המכונן את ההווה - עיצובה של ההיסטוריוגרפיה המקראית בסוף ימי הבית הראשון ולאחר החורבן, הוצאת ארנה הס, ירושלים, 2002

RAVITZKY, Aviezer - Haketz Hameguleh U-Medinat HaYehudim - Meshihiut, Zionut Ve-Radikalizm Dati Be-Israel, Al Oved, Tel Aviv, 2001 רביצקי, אביעזר - הקץ המגולה ומדינת היהודים - משיחיות, ציונות ורדיקליזם דתי בישראל, עם עובד, תל אביב, 2001

SAGUI, Avi (editor) - Emunah Be-Zmanim Mishtanim - Al Mishato Shel HaRav Yosef Dov Soloveitchik, Hmahlakah Le-Hinukh U-Le-Tarbut Toraniim Ba-Golah, Jerusalem, 1996

שגיא, אבי (עריכה) - אמונה בזמנים משתנים - על משנתו של הרב יוסף דב סולובייצ'יק, המחלקה לחינוך ולתרבות תורניים בגולה, ירושלים, 1996

SCHWARTZ, Dov - "HaRav Yosef Dov Soloveitchik Ve-HaShoah - Yunim Be-Kol Dodi Dofek" in Ke-Lavi Shakhan, Hamakhon Ha-Torani Or Ezion

שוורץ, דב - "הרב יוסף דב סולובייציק והשואה - עיונים ב- קול דודי דופק" ב- כלביא שכן, המכון התורני אור עציון, תשס"ג

SCHWARTZ, Dov - "Mishnato Shel HaRav Y.D. Soloveitchik Be-Raei HaHagut HaZionit HaDatit: HaHilon Ve-HaMedinah" in Emunah Be-Zmanim Mishtanim - Al Mishato Shel HaRav Yosef Dov Soloveitchik, editado por Avi Sagui, Hmahlakah LeHinukh U-Le-Tarbut Toraniim Ba-Golah, Jerusalem, 1996 שוורץ, דב - "משנתו של הרב י"ד סולובייציק בראי ההגות הציונית הדתית: החילון והמדינה" ב- אמונה בזמנים משתנים - על משנתו של הרב יוסף זב סולובייצ'יק, אבי שגיא (עריכה) , המחלקה לחינוך ולתרבות תורניים בגולה, ירושלים, 1996

SHOHAT, Azriel - "Kidush Ha-Shem Be-Hagutam Shel Megurashei Sepharad UMekubalei Zfat" in Milhamat Kodesh U-Martirologiah Be-Toldot Israel U-Betoldot Haamim, Ha-Hevrah Ha-Historit Ha-Israelit, Jerusalem שוחט, עזריאל - "קידוש השם בהגותם של מגורשי ספרד ומקובלי צפת" , מלחמת קודש ומארטירולוגיה בתולדות ישראל ובתולדות העמים, החברה ההיסטורית הישראלית, ירושלים, תשכ"ח 
TURKEL, Eli - Mekorot HaRav - Maftehot U-Bibliografia Le-Torat HaRav Yosef

Dov Soloveitchik Lefi Nosim U-Mekorot, Hozaat Reuven Mass, Jerusalem, 2001

טורקל, אלי וטורקל, חיים - מקורות הרב - מפתחות וביבליוגרפיה לתורת הרב יוסף דוב סולובייציק לפי נושאים ומקורות, הוצאת ראובן מם, ירושלים, 2001

YSRAELI, Shaul; Lamm, Nahum; Raphael, Ytzhak - $\underline{\text { Sefer Yovel Li-khvod Morenu }}$ HaGaon Rabi Yosef Dov Soloveitchik Shlita, Yeshivah University, New York, 1984 ישראלי, שאול ולאם, נחום ורפאל, יצחק - ספר יובל לכבוד מורנו הגאון רבי יוסף דוב הלוי סולובייצ'יק שליט"א, ישיבה אוניברסיטה, ניו-יורק, 1984

\section{OBRAS DE REFERÊNCIA}

The Babylonian Talmud - editado e traduzido por I. Epstein, The Soncino Press, London, 1948

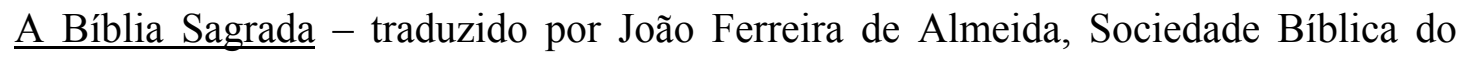
Brasil, Barueri, 1993

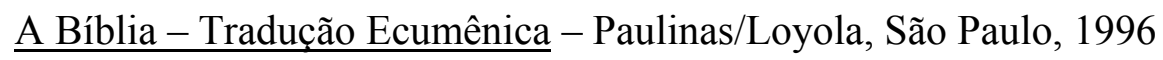

Encyclopedia Judaica - Keter Publishing House, Jerusalem, 1972

Encyclopaedia Judaica, $2^{\text {nd }}$ Edition - Keter Publishing House, Jerusalem e MacMillan, Detroit, 2007.

The Encyclopedia of Religion, editado por Mircea Eliade, MacMillan Publishing Company, New York, 1987

The Holy Scriptures - traduzido por Harold Fisch, Koren Publishers, Jerusalem, 1992

The Midrash on Psalms - editado e traduzido por William G. Braude, Yale University Press, New Haven, 1959.

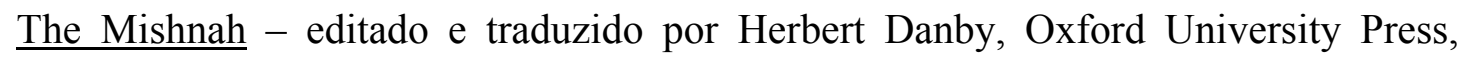
London, 1949.

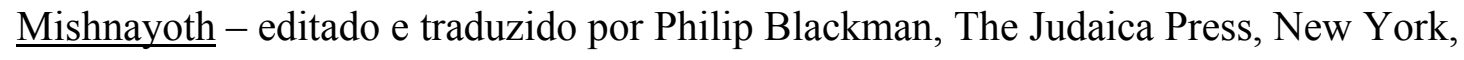
1963

Talmud Bavli, Maadurot Shotenstein, Hozaat Artscroll, New York, 1997 תלמוד בבלי, מהדורות שוטנשטין, הוצאת ארטסקרול, ניו יורק, 1997 
Talmud Bavli, Steinzaltz, HaMakhon HaIsraeli Le-Pirsumim Talmudiim, Jerusalem, 2001

$$
\text { תלמוד בבלי, שטיינזלץ, המכון הישראלי לפרסומים תלמודיים, ירושלים, } 2001
$$

The Talmud of Babylonia - An Academic Commentary - editado por Jacob Neusner, South Florida Academic Commentary Series, Scholars Press, Atlanta, 1996

The Tosefta - editado e traduzido por Jacob Neusner, Ktav Publishing House, New York, 1981

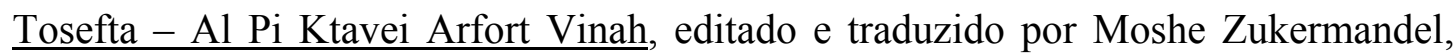
Sifrei Varman, Jerusalem

תוספתא - על פי כתבי יד ערפורט ווינה, מאת משה ש. צוקרמאנדל, ספרי ואהרמן, ירושלים, תש"ל

\section{SITES DE INTERNET}

Encyclopaedia Britannica (www.britannica.com)

\section{PADRONIZAÇÕES ADOTADAS NESTA TESE:}

RODRIGUES, André Figueiredo - Como Elaborar Citações e Notas de Rodapé, $3^{\mathrm{a}}$ edição, Associação Editorial Humanitas, São Paulo, 2005

RODRIGUES, André Figueiredo - Como Elaborar e Apresentar Monografias, Associação Editorial Humanitas, São Paulo, 2005

RODRIGUES, André Figueiredo - Como Elaborar Referência Bibliográfica, $5^{\text {a }}$ edição, Associação Editorial Humanitas, São Paulo, 2005 